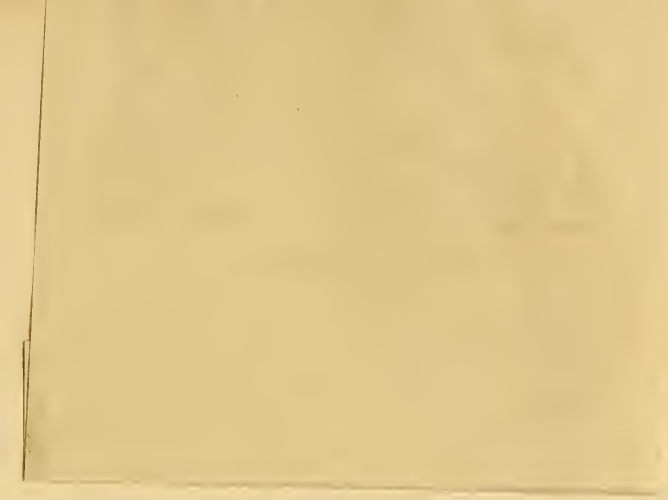

\title{
DENSITY AND THERMAL EXPANSION OF ETHYL ALCOHOL AND OF ITS MIXTURES WITH WATER
}

\author{
By N. S. Osborne, E. C. McKelvy, and H. W. Bearce \\ CONTENTS
}

INTRODUCTION.

Page 328

Part 1.-PREPARATION OF PURE ANHYDROUS ETHYL ALCOHOL

I. Historical SURVEY...................................... 330

I. Work before $186_{5}$-Comparison of results............. $33^{\mathrm{I}}$

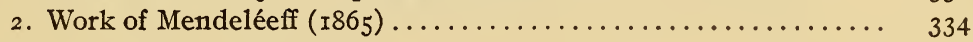

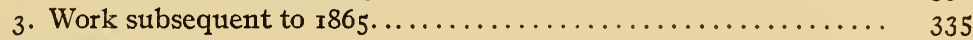

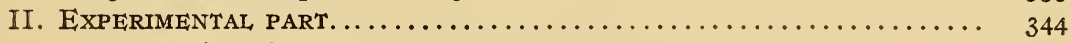

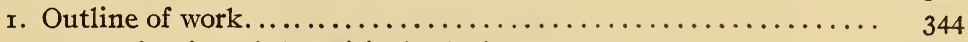

2. Determination of the critical solution temperature.......... 344

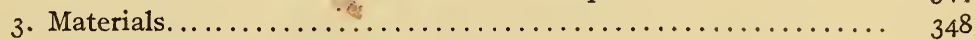

4. Purification and testing for impurities................ 349

5. Dehydration and distillation of the alcohol.............. 353

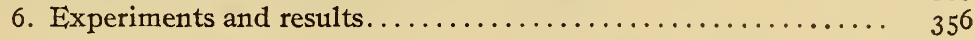

7. Effect of impurities on the density $\ldots \ldots \ldots \ldots \ldots \ldots \ldots \ldots \ldots{ }_{367}$

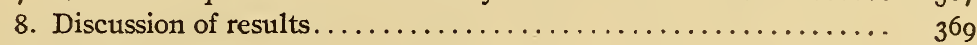

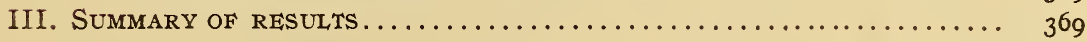

Part 2.-THERMAL EXPANSION OF MIXTURES OF ETHYL ALCOHOL AND WATER

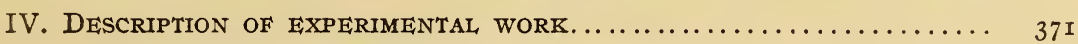

I. Method of determination and general description of apparatus... 37 I

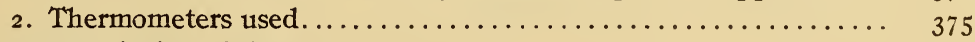

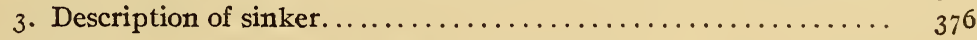

4. Balance, weights, and method of weighing............. 377

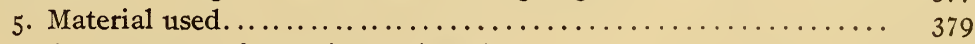

6. Arrangement of experimental work................ 379

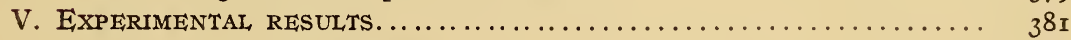

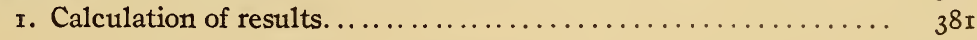

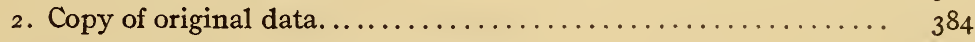

3. Reduction and adjustment of results................ 385

4. Résumé of results......................... 399 
Part 3.-DENSITY OF ETHYL ALCOHOL AND OF ITS MIXTURES WITH WATER

VI. DESCRIPTION OF APPARATUS AND EXPERIMENTAL WORK.......... Page 405

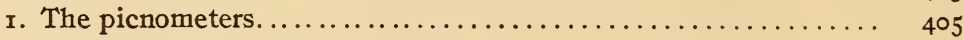

2. Effect of dissolved air......................... 407

3. Determination of the density of ethyl alcohol............ 409

4. Preparation of mixtures. Apparatus and methods used ....... 4. $4 \mathrm{I}_{5}$

5. Materials used.................................... $4 \mathrm{I} 8$

6. Experimental work and reduction of results............. 420

7. Alcoholometric density table.................... 424

8. Review of results. ......................... 428

Part 4.-DENSITY OF ETHYL ALCOHOL AND OF ITS MIXTURES WITH WATER. (A CONFIRMATORY SERIES)

VII. DESCRIPTION OF EXPERIMENTAL, WORK................. 429

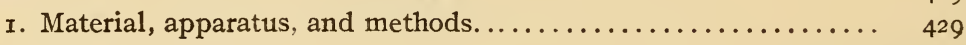

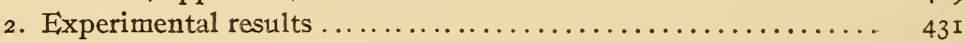

Part 5.-BIBLIOGRAPHY

VIII. BIBLIOGRAPHY OF THE LITERATURE ON ALCOHOL AND ALCOHOLOMETRY. . 436

I. References in chronological order................. 437

2. Decimal classification of subjects.................. 468

\section{INTRODUCTION}

The demand for alcoholometric density tables of greater precision than those now in use has led to the experimental redetermination at the Bureau of Standards of the constants upon which such tables are based.

In order to provide the basis for the standardization of alcoholometers at this bureau, the work of preparing such tables was undertaken several years ago. Examination of the data then available showed that they were inadequate for the preparation of tables of the desired accuracy.

The scope of the present work includes the preparation of pure anhydrous ethyl alcohol, the determination of the density and thermal expansion of this alcohol and its mixtures with water, and the construction from these data of tables for convenient use.

The results of the density determinations by the authors are expressed in terms of the density of water at $4^{\circ} \mathrm{C}$ as the unit. The word "density" is employed throughout the paper in a general way as the name of the property of the substance; but where numerical values are given, whether those determined by the 
authors or quoted from other observers, the unit employed is either expressed in words or indicated by symbols.

The symbol $D \frac{t}{T}$ indicates the density of a substance at the temperature $t$ in terms of the density of water under normal atmospheric pressure at the temperature $T$ as the unit. The density expressed thus is equivalent to the ratio ${ }^{a}$ of the density of the substance at $t^{\circ}$ to the density of water at $T^{\circ}$, and in the case where $T$ equals $4^{\circ} \mathrm{C}$ the density is equivalent to density expressed in grams per millimeter. If not otherwise indicated, temperatures are on the centigrade scale, and for the experimental work presented here the International Hydrogen Scale of temperatures is used. 


\title{
PART 1
}

\section{PREPARATION OF PURE ANHYDROUS ETHYL ALCOHOL}

\author{
By E. C. McKelvy
}

The success of an attempt to prepare a pure material of any kind depends largely on its physical state at ordinary temperatures and on the limitations set by the nature of the physical properties, which may be determined in order to detect the impurities present. Generally speaking, chemical methods for detecting very small quantities of one substance in large quantities of another are rather poorly developed and unsatisfactory, especially in the field of organic substances. The present work presented the problem of preparing a pure liquid, ethyl alcohol, with many favorable conditions under which to work. The impurities contained in the product on the market are comparatively few, and there is no great difficulty in getting large quantities of the liquid containing 99.5 per cent ethyl alcohol. The problem resolved itself into a removal of the half per cent of impurity, mostly water, and the study of the variation of the physical properties of alcohol with small amounts of various impurities. The purification can be carried out by distillation at temperatures easily attainable, and the permissibility of working with large quantities of the liquid is a distinct advantage, especially in the preliminary purification. A considerable number of physical properties are applicable to the testing of the product, with, however, a large variation in their sensitiveness. It is evident that our knowledge of the purity of any material is subject to the limits set by the method of testing, whatever may be the efficiency of the method of purification.

\section{HISTORICAL SURVEY}

It was early appreciated that the most convenient basis upon which alcoholic liquors could be taxed was their alcohol content. The accurate determination of this value has occupied the attention of investigators for over a century, and several independent 
methods have been devised. A study of the literature on the subject will show that a number of physical constants have been proposed for this use. By far the larger bulk of the work, however, has had to do with the determination of the densities of alcohol-water mixtures, since a density determination gives an easy and accurate method of determining the alcoholic content of a liquor.

To utilize this method practically, it is of course necessary first to construct a table from density determinations on mixtures of known composition. In order that this may be done, it is essential that pure alcohol should be obtained. The efforts at the preparation of such an alcohol have been parallel with the development in the accuracy of alcoholometric tables. It is purposed to give a short historical survey of the main attempts to accomplish this result.

\section{WORK BEFORE 1865-COMPARISON OF RESULTS.}

It can be said concerning most of the results recorded before I 865 , and of many since, that they are of limited accuracy, and hence of interest mainly from a historical point of view, notwithstanding that a part of this work forms the basis of the tables in current use. The main cause of this status is that the actual density determinations are generally given only to the fourth decimal place, and as a rule the results are poorly defined as to temperature conditions and bases of temperature and density references. A considerable part of this work has been briefly sketched in the papers of Mendeléeff $b, 207,241$ and Gerlach ${ }^{445}$. Blagden and Gilpin ${ }^{4,5}$ were among the first investigators to construct tables from actual density determinations. Their work was incomplete in that no success attended their efforts to obtain anhydrous alcohol, and so their results had only an arbitrary significance until the real alcohol value of their basis could be determined by later observers. The early attempts of Lowitz ${ }^{10}$ and Richter ${ }^{9,11}$ to dehydrate alcohol, and the work of Tralles ${ }^{20}$ have been thoroughly discussed by Windisch ${ }^{684}$. Table I will show the surprising agreement shown in the results of some of

$\checkmark$ Reference numbersprinted in superior figures throughout this paper refer to "Bibliography," part 5. in which each title bears a specific reference number. 
the experimenters working before 1865 . McCulloch ${ }^{105,}{ }^{119}$ in a report to the Secretary of the Treasury of the United States reviews the work done up to that time, and on the basis of a few experiments and recalculations of his own recommends the alcoholometric tables for official use by the Treasury Department.

\section{TABLE I}

Density Determinations of Absolute Alcohol Prior to 1866

\begin{tabular}{|c|c|c|c|c|c|c|}
\hline Name & Year & Dehydrator & $\begin{array}{c}\text { Density } \\
\text { value } \\
\mathrm{D}_{\mathrm{T}}^{\mathrm{t}}\end{array}$ & $\begin{array}{c}\text { Basis of } \\
\text { reference } \\
\frac{t}{T}\end{array}$ & $\begin{array}{l}\text { Density } \\
\frac{20^{\circ}}{4^{\circ}} \\
\text { recalcu- } \\
\text { lated }\end{array}$ & Remarks \\
\hline Blagden and Gilpin 4, $5 .$. & $\left\{\begin{array}{c}1790 \\
\text { to } \\
1794\end{array}\right\}$ & None... & 0.825 & $\frac{60^{\circ}}{60^{\circ}} \mathrm{F}$ & & $\left\{\begin{array}{l}\text { No dehydrating } \\
\text { agent }\end{array}\right.$ \\
\hline Lowitz ${ }^{10} \ldots .$. & 1796 & $\mathrm{~K}_{2} \mathrm{CO}_{3} \ldots$ & .791 & $\frac{16^{\circ}}{16^{\circ} \mathrm{C}}$ & 0.7899 & M. \\
\hline Richter ${ }^{9}, 11 \ldots \ldots$ & 1797 & $\mathrm{CaCl}_{2}$ & .792 & $\frac{20^{\circ}}{20^{\circ}} \mathrm{C}$ & .7909 & M. \\
\hline Saussure ${ }^{17} \ldots \ldots \ldots$ & 1807 & $\mathrm{CaCl}_{2}$. & .792 & $\frac{16^{\circ}}{16^{\circ}} \mathrm{C}$ & .7909 & M. \\
\hline Gay-Lussac ${ }^{25} \ldots \ldots \ldots$ & 1815 & $\mathrm{CaO} .$. & .7940 & $\frac{15^{\circ}}{4^{\circ}} \mathrm{C}$ & . 7898 & M. \\
\hline Meissner ${ }^{27} \ldots$. & 1816 & $\mathrm{CaCl}_{2} .$. & .791 & $\frac{20^{\circ}}{20^{\circ} \mathrm{C}}$ & .7899 & M. \\
\hline Delezennes $32 . .$. & 1823 & & .79370 & $\frac{20^{\circ}}{0^{\circ} \mathrm{C}}$ & .79361 & M. \\
\hline Gouvernain ${ }^{38} . .$. & 1825 & & .79364 & $\frac{16^{\circ}}{10^{\circ}} \mathbf{R}$ & .79348 & M. \\
\hline Dumas and Boullay $\mathfrak{l l}^{1 . . . . . . . ~}$ & 1827 & $\mathrm{CaCl}_{2} .$. & .7915 & $\frac{18^{\circ}}{\mathrm{X}^{\circ} \mathrm{C}}$ & .7899 & A. \\
\hline Muncke and Gmelin $47,52$. & 1828 & & .8062 & $\frac{0^{\circ}}{4^{\circ}} \mathrm{C}$ & .7895 & M. \\
\hline Brown $48 \ldots$ & 1829 & & .791 & & & \\
\hline Connell $53 . .$. & 1835 & $\mathrm{CaO} .$. & .7938 & $\frac{60^{\circ}}{\mathrm{X}^{\circ}} \mathrm{F}$ & .7896 & A. Assume $x^{\circ}=$ \\
\hline Kopp ${ }^{83} \ldots \ldots$ & 1845 & & .80950 & $\frac{0^{\circ} \mathrm{C}}{0^{\circ} \mathrm{C}}$ & .79277 & M. \\
\hline Plerre ${ }^{84} \ldots$. & 1845 & $\mathrm{CaO} .$. & .81508 & $0^{\circ} \div \mathrm{C}$ & .79777 & $\begin{array}{l}\text { M. Pierre's expan- } \\
\text { sion coefficient } \\
\text { used }\end{array}$ \\
\hline Fownes ${ }^{90}$.. & 1847 & $\mathrm{CaO} .$. & .7938 & $\frac{60^{\circ}}{60^{\circ}} \mathrm{F}$ & .78959 & M. \\
\hline Wackenroder ${ }^{97}$... & 1847 & $\mathrm{CaO} .$. & .7948 & $\frac{21^{\circ}}{\mathrm{X}^{\circ}} \mathrm{C}$ & .7905 & A. \\
\hline
\end{tabular}


TABLE I-Continued

\begin{tabular}{|c|c|c|c|c|c|c|}
\hline Name & Year & Dehydrator & $\begin{array}{c}\begin{array}{c}\text { Density } \\
\text { value } \\
\mathrm{D}_{\overline{\mathrm{T}}}^{\mathrm{t}}\end{array}\end{array}$ & $\begin{array}{c}\text { Basis of } \\
\text { reference } \\
\frac{t}{\mathbf{T}}\end{array}$ & $\begin{array}{l}\text { Density } \\
\frac{20^{\circ}}{4^{\circ}} \\
\text { recalcu- } \\
\text { lated }\end{array}$ & Remarks \\
\hline Drinkwater ${ }^{102} \ldots$ & 1848 & $\mathrm{CaO} . .$. & 0.793811 & $\frac{60^{\circ}}{60^{\circ}} \boldsymbol{F}$ & 0.78958 & M. \\
\hline Wetherll1 $109 .$. & 1848 & & .8194 & $\frac{19^{\circ}}{\mathrm{X}^{\circ} \mathrm{C}}$ & .8073 & A. \\
\hline Plucker $132 \ldots$ & 1854 & $\mathrm{CaO}$. & .792 & $\frac{13: 75}{\mathrm{X}^{\circ}} \mathrm{C}$ & .787 & A. \\
\hline Delffs $128 \ldots$ & 1854 & & .809 & $\frac{5^{\circ}}{\mathrm{X}^{\circ} \mathrm{C}}$ & .796 & A. \\
\hline Pouillet 152 . & 1859 & & .7947 & $\frac{15^{\circ}}{15^{\circ}} \mathrm{C}$ & .7898 & ML. \\
\hline Baumhauer ${ }^{155}$.. & 1860 & $\mathrm{CaO} .$. & .7939 & $\frac{15^{\circ}}{4^{\circ} \mathrm{C}}$ & .7897 & A. \\
\hline Mendeléeff ${ }^{172} \ldots$ & 1861 & & .7958 & $\frac{15^{\circ}}{4^{\circ}} \mathrm{C}$ & .7916 & A. \\
\hline Gladstone-Dale 188 & 1863 & & .7972 & $\frac{20^{\circ}}{\mathrm{X}} \mathrm{C}$ & .7929 & A, \\
\hline Landolt $199 \ldots . .$. & 1864 & $\mathrm{CaO}-\mathrm{Na} \ldots .$. & .8011 & $\frac{20^{\circ}}{20^{\circ}} \mathrm{C}$ & .7997 & A. \\
\hline Mendeléeff 207, 241 . & 1865 & $\mathrm{CaO}-\mathrm{BaO} .$. & .78945 & $\frac{20^{\circ}}{4^{\circ} \mathrm{C}}$ & .78945 & Uncorrected \\
\hline
\end{tabular}

EXPLANATION.-In the column headed "Remarks" M indicates that the densities at $20^{\circ}$ were calculated by Mendeléeff. A indicates that this was done by the authors of this paper. Both calculations were made, except where otherwise stated, with Kopp's ${ }^{92,}{ }^{241}$ value for the expansion in the following formula:

$$
D \frac{\mathrm{t}^{\circ}}{4^{\circ}}=D \frac{20^{\circ}}{4^{\circ}}+\left(20^{\circ}-\mathrm{t}^{\circ}\right) 0.000846
$$

where 0.000846 is the change in density for $\mathrm{I}^{\circ} \mathrm{C}$. $\mathrm{X}^{\circ}$ signifies that the basis of density reference was not given and is assumed to be $4^{\circ}$ in the recalculation. It is impossible to correct any of these values, except Mendeléeff's ${ }^{207}{ }^{241}$ later one, to the international hydrogen scale of temperature. 


\section{WORK OF MENDELEEEFF (1865)}

In 1865 Mendeléeff's ${ }^{207}$ memoir on alcohol appeared in the original Russian and also in German. His experimental work is characterized by careful attention to details and skillful execution. The ethyl alcohol prepared by him was probably the purest prepared up to that time. His density values have been generally regarded with great confidence. Many of the generally accepted tables used in scientlfic work have as their basis Mendeléeff's value, with the application of certain well-defined corrections. Such are the tables prepared by Windisch, ${ }^{885}$ using the value approved by the Normal-Eichungs Commission, Berlin; the tables given by $\mathrm{E}$. W. Morley, ${ }^{1050}$ using a value recalculated by himself; and the tables issued provisionally by the Bureau of Standards ${ }^{1216}$ in 1909.

In Mendeléeff's work the first attempt was made to determine the relative efficiency of different dehydrating agents. From the results of previous investigators, as well as experiments of his own, he decided that such agents as anhydrous potassium carbonate, calcium chloride, and copper sulphate were unsatisfactory. Metallic sodium as such or in the form of an amalgam he found inefficient, an observation later substantiated by Squibb ${ }^{433}$ and by Crismer. ${ }^{1033} \mathrm{He}$ concluded that lime, with the addition of a smaller quantity of baryta, was the most satisfactory means for dehydrating the alcohol. This addition of baryta had been recommended by Berthelot, ${ }^{141}$ with the statement that the turning brown of the alcohol was an indication of complete dehydration, but it was later shown by Crismer ${ }^{1033}$ that the baryta is unnecessary and undesirable.

In Table II are given the lowest density values found by Mendeléeff in his work with different dehydrating agents, certain of which are still in use. These results, if more generally known, would leave no doubt in the minds of chemists as to the agents which should be used if an alcohol as anhydrous as possible is desired. Table III contains the results of one of Mendeleeff's and one of Squibb's later distillations, showing the variation in the density of the different fractions. Unfortunately the volumes of the different fractions are not given. 
TABLE II

Densities with Various Dehydrating Agents (Mendeléeff ${ }^{007,241}$ )

\begin{tabular}{|c|c|c|}
\hline Dehydrator used & $D \frac{20^{\circ}}{4^{\circ}}$ & Remarks \\
\hline $\begin{array}{l}\mathrm{K}_{2} \mathrm{CO}_{3} \\
\mathrm{CaCl}_{2} \\
\mathrm{CuSO}_{4} \\
\mathrm{Na}-\mathrm{Hg}_{4} \\
\mathrm{BaO} \\
\mathrm{CaO}+\mathrm{BaO}\end{array}$ & $\begin{array}{l}0.78970 \\
.78960 \\
.78961 \\
.78974 \\
.789453 \\
.78945\end{array}$ & $\begin{array}{l}\text { All distillations were made with the dehydrating } \\
\text { agent present in the alcohol. No corrections } \\
\text { have been applied to the results. }\end{array}$ \\
\hline
\end{tabular}

\section{TABLE III}

Variations in Density of Distillate Fractions

[Dehydrating agents: Mendeléeff, $\mathrm{CaO}+\mathrm{BaO}$; Squibb, $\mathrm{CaO}$.]

\begin{tabular}{|c|c|c|c|}
\hline Fraction & $\begin{array}{l}\mathrm{D}_{\frac{4^{\circ}}{20^{\circ}}} \\
\text { Mendeléeff } 207,241\end{array}$ & $\begin{array}{l}\quad D_{15 \% 6}^{1596} \\
\text { E. R. Squibb } 6 \pi s\end{array}$ & Remarks \\
\hline $\begin{array}{l}1 \\
2 \\
3 \\
4 \\
5 \\
6 \\
7\end{array}$ & $\begin{array}{r}0.78963 \\
.78946 \\
.789442 \\
.789456 \\
.789442 \\
.789472 \\
\ldots . . . . . . . \\
\end{array}$ & $\begin{array}{r}0.793960 \\
.793811 \\
.793639 \\
.793582 \\
.793576 \\
.793561 \\
.793499\end{array}$ & $\begin{array}{l}\text { These results are taken directly from } \\
\text { the original articles without correc- } \\
\text { tion. The volume figures for the } \\
\text { fractions are not available. }\end{array}$ \\
\hline
\end{tabular}

\section{WORK SUBSEQUENT TO 1865}

In Table IV are presented the results of most importance which have appeared since 1865 . Table $\mathrm{V}$ shows the values obtained by other investigators during this period in cases where generally the density value was of secondary importance to the determination of other physical constants. In most of these cases no details of the density determinations are given. 
TABLE IV

Ethyl Alcohol Density Determinations of Most Importance Subsequent to 1864

\begin{tabular}{|c|c|c|c|c|c|}
\hline Name & Year & Dehydrator used & $\begin{array}{c}\text { Density } \\
\text { value given } \\
D_{\frac{t}{T}}^{t}\end{array}$ & $\begin{array}{c}\text { Basis of } \\
\text { reference } \\
\frac{t}{T}\end{array}$ & $\begin{array}{c}\text { Density } \\
\text { at } 25^{\circ} \text { (cal- } \\
\text { culated) } \\
D^{2} \frac{25}{4} \mathrm{C}\end{array}$ \\
\hline Mendeléeff ${ }^{207,241} \ldots$ & 1865 & $\mathrm{CaO}+\mathrm{BaO} .$. & 0.79358 & $\frac{15^{\circ}}{4^{\circ}}$ & 0.78504 \\
\hline Squibb, Messrs. ${ }^{433}$.. & 1884 & $\mathrm{CaO}$ & .79350 & $\frac{15: 6}{15: 6}$ & .78470 \\
\hline Squibb, E. R. ${ }^{679} \ldots$... & 1893 & $\mathrm{CaO} \ldots . .$. & .79356 & $\frac{15: 6}{15: 6}=$ & .78476 \\
\hline Cook and Haines ${ }^{933}$ & 1901 & $\mathrm{CaC}_{2} \ldots \ldots$ & .79357 & $\frac{15^{\circ}}{4^{\circ}}$ & .78503 \\
\hline Young ${ }^{986} . . . .$. & 1902 & Dist. w. hexane.. & .80627 & $\frac{0^{\circ}}{4^{\circ}}$ & .78507 \\
\hline Crismer ${ }^{1033} \ldots$ & 1904 & $\mathrm{CaO} \ldots$ & .78746 & $\frac{25^{\circ}}{25^{\circ}}$ & .78516 \\
\hline Winkler ${ }^{1087} .$. & 1905 & $\mathrm{Ca} . . . .$. & .78932 & $\frac{20: 07}{4^{\circ}}$ & .78510 \\
\hline Klason and Norlin 1109 & 1906 & $\mathrm{Ca} . .$. & .79413 & $\frac{15^{\circ}}{15^{\circ}}$ & .78490 \\
\hline Do... & & $\mathrm{Ca} \ldots$ & .78938 & $\frac{20^{\circ}}{4^{\circ}}$ & .78508 \\
\hline Kailan ${ }^{1148}$.. & 1907 & $\mathrm{CaO} \ldots$ & .78520 & $\frac{25^{\circ}}{4^{\circ}}$ & .78520 \\
\hline Andrews ${ }^{1167}$.. & 1908 & $\mathrm{CaO}, \mathrm{Ca}, \mathrm{Mg}-\mathrm{Hg}$ & .78510 & $\frac{25^{\circ}}{4^{\circ}}$ & .78510 \\
\hline Doroshevskii ${ }^{1175}: \ldots$ & 1908 & $\mathrm{CaO} . .$. & .79426 & $\frac{15^{\circ}}{15^{\circ}}$ & .78503 \\
\hline $\begin{array}{l}\text { Acree and Robert- } \\
\text { Son }^{1257,1294}\end{array}$ & 1910 & $\mathrm{CaO} . .$. & .78506 & $\frac{25^{\circ}}{4^{\circ}}$ & .78506 \\
\hline Dorosherskii ${ }^{1269} \ldots$ & 1910 & $\mathrm{CaO} . .$. & .79412 & $\frac{15^{\circ}}{15^{\circ}}$ & .78489 \\
\hline Röhrs ${ }^{1295} \ldots$ & 1910 & $\mathrm{Ca} .$. & .795027 & $\frac{14: 2}{14: 2}$ & .78521 \\
\hline Kailan ${ }^{1341} \ldots$... & 1911 & $\mathrm{CaO} \ldots .$. & .78513 & $\frac{25^{\circ}}{4^{\circ}}$ & .78513 \\
\hline Bureau Standards s 1376 & 1910 & $\mathrm{CaO}, \mathrm{Al}-\mathrm{Hg} .$. & .78506 & $\frac{25^{\circ}}{4^{\circ}}$ & .78506 \\
\hline
\end{tabular}


Explanation.-Table IV represents an attempt to put the most important results for the density of anhydrous alcohol on a comparable basis. All reductions were made with the use of the formula obtained in Part II,

$$
D_{4^{\circ}}^{\mathrm{t}^{\circ}}=D_{\frac{4}{4}^{\circ}}^{20}-\left[859(t-25)+0.6(t-25)^{2}+0.005(t-25)^{3}\right] \times 10^{-6}
$$

and Chappuis's ${ }^{1132}$ values for the density of water. The value given in Mendeléeff's original paper has been corrected to a more probable value for the density of water than that assumed by him and to the international hydrogen temperature scale.

TABLE V

Density Determinations of Secondary Importance Subsequent to 1865

\begin{tabular}{|c|c|c|c|c|c|}
\hline Name & Year & Dehydrator & $\begin{array}{c}\begin{array}{c}\text { Density } \\
\text { value }\end{array} \\
D_{\bar{T}}^{t}\end{array}$ & $\begin{array}{c}\text { Basis of } \\
\text { reference } \\
\frac{t}{T}\end{array}$ & 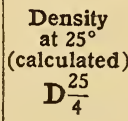 \\
\hline Linnemann $^{231} \ldots$ & 1868 & $\mathrm{~K}_{2} \mathrm{CO}_{3} \ldots$ & 0.8086 & $\frac{19^{\circ}}{19^{\circ}}$ & 0.8022 \\
\hline Wïllner ${ }^{234} \ldots \ldots \ldots$ & 1868 & & .8133 & $\frac{0^{\circ}}{x^{\circ}}$ & .7920 \\
\hline Darling ${ }^{225} \ldots$ & 1868 & & .8095 & $\frac{0^{\circ}}{x^{\circ}}$ & .7926 \\
\hline Dupré and Page ${ }^{237} \ldots$. & 1869 & & .79792 & $\frac{10^{\circ}}{x^{\circ}}$ & .78516 \\
\hline Do... & 1869 & & .79317 & $\frac{15: 5}{x^{\circ}}$ & .78509 \\
\hline Do...... & 1869 & & .78932 & $\frac{20^{\circ}}{x^{\circ}}$ & .78507 \\
\hline van der Willigen ${ }^{245}$. & 1869 & & .7935 & $\frac{20^{\circ}}{4^{\circ}}$ & .7892 \\
\hline Pierre and Puchot ${ }^{260} \ldots$... & 1871 & & .822 & $\frac{20^{\circ}}{x^{\circ}}$ & .818 \\
\hline Erlenmeyer ${ }^{254}$. & 1871 & $\mathrm{CaO} .$. & .79481 & $\frac{11^{\circ}}{x^{\circ}}$ & .78291 \\
\hline Pierre ${ }^{283} \ldots$ & 1873 & & .80214 & $\frac{15^{\circ}}{x^{\circ}}$ & .79460 \\
\hline Winkelmann ${ }^{285}$. & 1873 & & .7946 & $\frac{16: 03}{4^{\circ}}$ & .78695 \\
\hline
\end{tabular}


TABLE V-Continued

\begin{tabular}{|c|c|c|c|c|c|}
\hline Name & Year & Dehydrator & $\begin{array}{c}\begin{array}{c}\text { Density } \\
\text { value }\end{array} \\
\mathbf{D}_{\mathrm{T}}^{\mathrm{t}}\end{array}$ & $\begin{array}{c}\text { Basis of } \\
\text { reference } \\
\frac{t}{T}\end{array}$ & $\begin{array}{c}\text { Density } \\
\text { at } 25^{\circ} \\
\text { (calculated) } \\
D_{\frac{25}{4}}^{25}\end{array}$ \\
\hline Duclaux ${ }^{312} .$. & 1877 & & 0.7947 & $\frac{15^{\circ}}{4^{\circ}}$ & 0.7860 \\
\hline Kundt ${ }^{322} \ldots$... & 1878 & & .800 & $\frac{18^{\circ}}{x^{\circ}}$ & .794 \\
\hline Briihl ${ }^{343} \ldots \ldots$ & 1880 & & .8000 & $\frac{20^{\circ}}{4^{\circ}}$ & . 7957 \\
\hline De Heen ${ }^{347}$. & 1880 & & .7995 & $\frac{14^{\circ}}{x^{\circ}}$ & .7901 \\
\hline Lorenz ${ }^{350} \ldots$ & 1880 & & .7909 & $\frac{20^{\circ}}{x^{\circ}}$ & .7866 \\
\hline Vincent and Delachanal ${ }^{359} .$. & 1880 & & .8120 & $\frac{0^{\circ}}{x^{\circ}}$ & .7908 \\
\hline Zettermann ${ }^{362} \ldots$ & 1880 & & .799 & $\frac{17: 5}{x^{\circ}}$ & .793 \\
\hline Bedson and Williams ${ }^{364} .$. & 1881 & & .8019 & $\frac{20^{\circ}}{4^{\circ}}$ & .7976 \\
\hline Drecker ${ }^{400} \ldots$ & 1883 & & .78962 & $\frac{255^{\circ} 42}{x^{\circ}}$ & 78998 \\
\hline Johst ${ }^{405} \ldots$ & 1883 & & .8072 & $\frac{16: 7}{4^{\circ}}$ & 8000 \\
\hline Nasini ${ }^{408} \ldots$ & 1883 & $\mathrm{BaO} \ldots$ & .7968 & $\frac{20^{\circ}}{4^{\circ}}$ & . 7925 \\
\hline Quincke ${ }^{411} \ldots \ldots$ & 1883 & & .7969 & $\frac{20^{\circ}}{4^{\circ}}$ & .7926 \\
\hline Sieben ${ }^{414}$. . & 1883 & & .796 & $\frac{20^{\circ}}{4^{\circ}}$ & .792 \\
\hline Perkin ${ }^{431} \ldots$ & 1884 & $\mathrm{CuSO}_{4} \cdot$. & .78820 & $\frac{25^{\circ}}{25^{\circ}}$ & .78589 \\
\hline Kanonnikoff ${ }^{449}$. & 1885 & & .7918 & $\frac{20^{\circ}}{4^{\circ}}$ & .7875 \\
\hline $\begin{array}{c}\text { Winkelmann. } \\
\text { baum's alcohol.) }\end{array}$ & 1885 & & .7906 & $\frac{20^{\circ}}{4^{\circ}}$ & .7863 \\
\hline
\end{tabular}


TABLE V-Continued

\begin{tabular}{|c|c|c|c|c|c|}
\hline Name & Year & Dehydrator & 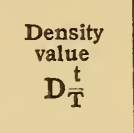 & $\begin{array}{c}\begin{array}{c}\text { Basis of } \\
\text { reference } \\
\frac{t}{T}\end{array} \\
\end{array}$ & $\begin{array}{c}\text { Density } \\
\text { at } 25^{\circ} \\
\text { (calculated) } \\
D_{\frac{25}{4}}\end{array}$ \\
\hline Pagliani and Batelli ${ }^{453}$. & 1885 & & 0.79175 & $\frac{18^{\circ}}{x^{\circ}}$ & 0.78580 \\
\hline Worthington ${ }^{463} \ldots \ldots \ldots \ldots$ & 1885 & & .7906 & $\frac{25: 3}{25^{\circ}}$ & .7885 \\
\hline Ketteler ${ }^{531} \ldots \ldots \ldots$ & 1388 & & .78987 & $\frac{20^{\circ}}{x^{\circ}}$ & .78562 \\
\hline Do.... & 1888 & & .80681 & $\frac{0^{\circ}}{x^{\circ}}$ & .78560 \\
\hline Ångstrom. ${ }^{512}$ (Air free).... & 1888 & & .80715 & $\frac{0^{\circ}}{4^{\circ}}$ & $\begin{array}{c}.78595 \\
.\end{array}$ \\
\hline Ångstrom. (Air saturated).. & 1888 & & .80680 & $\frac{0^{\circ}}{4^{\circ}}$ & .78559 \\
\hline Hartwig ${ }^{527}$. & 1888 & & . 7937 & $\frac{18^{\circ}}{4^{\circ}}$ & . 7877 \\
\hline Le Blanc ${ }^{563} \ldots$ & 1889 & & .79643 & $\frac{20^{\circ}}{20^{\circ}}$ & .79076 \\
\hline Barbier and Roux ${ }^{578}$ & 1890 & & .805 & $\frac{14^{\circ}}{x^{\circ}}$ & .796 \\
\hline Buchkremer ${ }^{581}$. & 1890 & & .7935 & $\frac{20^{\circ}}{4^{\circ}}$ & .7892 \\
\hline Gartenmeister ${ }^{584} \ldots \ldots$ & 1890 & & .7943 & $\frac{20^{\circ}}{4^{\circ}}$ & .7900 \\
\hline Korten ${ }^{588} \ldots$ & 1890 & & .7910 & $\frac{20^{\circ}}{4^{\circ}}$ & .7868 \\
\hline Jahn ${ }^{609} \ldots$ & 1891 & & .79149 & $\frac{20^{\circ}}{20^{\circ}}$ & .78585 \\
\hline Schall and Koss'ky ${ }^{622}$.. & 1891 & & .791861 & $\frac{18^{\circ}}{4^{\circ}}$ & .785883 \\
\hline Landolt and Jahn ${ }^{646}$.. & 1892 & & .80197 & $\frac{17: 5}{x^{\circ}}$ & .79557 \\
\hline Eykmann ${ }^{659} .$. & 1893 & & .7963 & $\frac{12: 7}{4^{\circ}}$ & .7856 \\
\hline
\end{tabular}


TABLE V-Continued

\begin{tabular}{|c|c|c|c|c|c|}
\hline Name & Year & Dehydrator & $\begin{array}{c}\underset{\text { Density }}{\text { value }} \\
D_{\frac{t}{T}}^{t}\end{array}$ & $\begin{array}{c}\text { Basis of } \\
\text { reference } \\
\frac{t}{T}\end{array}$ & $\left\{\begin{array}{c}\begin{array}{c}\text { Density } \\
\text { at } 25^{\circ} \\
\text { (calculated) } \\
\mathrm{D}^{25}\end{array}\end{array}\right.$ \\
\hline Edwards ${ }^{692} \ldots$ & 1894 & & 0.7964 & $\frac{20^{\circ}}{15 ! 5}$ & 0.7914 \\
\hline Tammann and Hirsch'g ${ }^{717}$. & 1894 & & .7951 & $\frac{15^{\circ}}{4^{\circ}}$ & .7866 \\
\hline Lehfeldt ${ }^{741} \ldots$ & 1895 & $\mathrm{CaO}-\mathrm{BaO}$ & .7929 & $\frac{18^{\circ}}{4^{\circ}}$ & .7869 \\
\hline Sohet ${ }^{818} \ldots$ & 1897 & & .8089 & $\frac{0: 9}{4^{\circ}}$ & .7885 \\
\hline Do..... & 1897 & & .7711 & $\frac{44: 7}{4^{\circ}}$ & .7879 \\
\hline Zecchini ${ }^{832} \ldots$ & 1897 & & .80513 & $\frac{1: 8}{4^{\circ}}$ & .78546 \\
\hline Cohen ${ }^{837} \ldots . .$. . & 1898 & $\mathrm{CaO}$. & .8063 & $\frac{0^{\circ}}{x^{\circ}}$ & .7851 \\
\hline Tanatar and Klimenko ${ }^{860} \ldots$ & 1898 & & .79565 & $\frac{15^{\circ}}{x^{\circ}}$ & .78711 \\
\hline $\begin{array}{l}\text { Loomis (Squibb). }{ }^{920} \text { (Deter- } \\
\text { mined by E. R. Squibb.) }\end{array}$ & 1900 & $\mathrm{CaO}$. & .79386 & $\frac{15: 6}{15: 6}$ & .78506 \\
\hline Carrara and Levi ${ }^{959} .$. & 1902 & & .79425 & $\frac{16^{\circ}}{4^{\circ}}$ & .78741 \\
\hline Grunmach ${ }^{966}$.. & 1902 & & .7888 & $\frac{22: 8}{4^{\circ}}$ & .7862 \\
\hline Szilard ${ }^{1083} \ldots$ & 1905 & $\mathrm{CaO} \ldots$ & .78990 & $\frac{20^{\circ}}{\mathrm{x}^{\circ}}$ & .78565 \\
\hline Cheneveau ${ }^{1133}$.. & 1907 & & .7886 & $\frac{22^{\circ}}{4^{\circ}}$ & .7860 \\
\hline Timmermanns ${ }^{1162} \ldots$ & 1907 & & .80664 & $\frac{0^{\circ}}{4^{\circ}}$ & .78544 \\
\hline $\begin{array}{l}\text { Wagner and Schulze. }{ }^{1164} \\
\text { (Alcohol from Winkler.) }\end{array}$ & 1907 & $\mathrm{Ca} . .$. & .793405 & $\frac{15^{\circ}}{4^{\circ}}$ & .78486 \\
\hline Getman ${ }^{1183}$.. & 1908 & & .78684 & $\frac{25^{\circ}}{4^{\circ}}$ & .78684 \\
\hline
\end{tabular}


TABLE V-Continued

\begin{tabular}{|c|c|c|c|c|c|}
\hline Name & Year & Dehydrator & $\begin{array}{c}\begin{array}{c}\text { Density } \\
\text { value } \\
D_{\frac{t}{T}}^{t}\end{array} \\
\text {. }\end{array}$ & $\begin{array}{c}\text { Basis of } \\
\text { reference } \\
\frac{t}{T} \\
\frac{T}{4}\end{array}$ & $\begin{array}{c}\text { Density } \\
\text { at } 25^{\circ} \\
\text { (calculated) } \\
\text { D } \frac{25}{4}\end{array}$ \\
\hline Herz and Kuhn ${ }^{1187} \ldots \ldots \ldots$ & 1908 & & 0.7867 & $\frac{25^{\circ}}{4^{\circ}}$ & 0.7867 \\
\hline $\begin{array}{l}\text { Richards and Mathews. }{ }^{1197} \\
(95 \text { per cent probably. })\end{array}$ & 1908 & & .8040 & $\frac{20^{\circ}}{4^{\circ}}$ & . 7997 \\
\hline Rühlemann ${ }^{1200} .$. & 1908 & & .7927 & $\frac{20^{\circ}}{4^{\circ}}$ & .7884 \\
\hline Turner ${ }^{1208} \ldots \ldots \ldots \ldots \ldots$ & 1908 & & .78948 & $\frac{20^{\circ}}{4^{\circ}}$ & .78520 \\
\hline Holmes and Sageman ${ }^{1232}$. & 1909 & $\mathrm{CaO} \ldots$ & .78892 & $\frac{25^{\circ}}{25^{\circ}}$ & .78661 \\
\hline Dawson ${ }^{1266}$.. & 1910 & & .791502 & $\frac{18^{\circ}}{4^{\circ}}$ & .78552 \\
\hline Polowzow ${ }^{1292}$.. & 1910 & & .78970 & $\frac{20^{\circ}}{4^{\circ}}$ & .78542 \\
\hline Smits and de Leeuw ${ }^{1308}$. & 1910 & & .7907 & $\frac{18^{\circ}}{4^{\circ}}$ & .7847 \\
\hline Thole ${ }^{1309} \ldots$ & 1910 & $\mathrm{Ca} . .$. & .7876 & $\frac{25^{\circ}}{4^{\circ}}$ & .7876 \\
\hline Warren ${ }^{1322}$. & 1910 & $\mathrm{CaO} \ldots$ & .7940 & $\frac{15^{\circ}}{15^{\circ}}$ & .7848 \\
\hline Cederberg ${ }^{1330}$. & 1911 & & .7907 & $\frac{19: 5}{x^{\circ}}$ & .7860 \\
\hline
\end{tabular}

The density value obtained by Messrs. Squibb ${ }^{433}$ is the lowest ever obtained. These investigators used freshly ignited lime as dehydrating agent. The treatment occupied several weeks and was made by percolation at ordinary temperatures. This work repeated by E. R. Squibb ${ }^{679}$ Io years later showed results only slightly higher. These authors concluded that they had not even then obtained anhydrous alcohol. The variation in density of their alcohol from that of Mendeléeff would represent an impurity of 0.03 per cent water in Mendeléeff's alcohol, assuming 
his higher value to be due to the presence of water. In the light of data to be presented later, it seems that these results can be explained on no other grounds than that in some way not known their standards of reference differed from those of other observers. In addition, there is some doubt concerning the precision of their temperature measurements. Cook and Haines ${ }^{933}$ neglected to give their basis of density reference. On the assumption that this is water at its maximum density it is found to differ only slightly from the more reliable results. This is the only quantitative result obtained, so far as known, by the use of calcium carbide as dehydrating agent. Young, ${ }^{986}$ without the use of chemical agents in the ordinary sense, obtained results in good accord with those of Mendeléeff. This was accomplished by distilling with benzene and with hexane. Crismer ${ }^{1033}$ has shown the inefficiency of sodium and baryta as dehydrating agents and obtained his best alcohol by means of dehydration with lime. $\mathrm{He}$ also introduced the use of the critical solution temperature of alcohol-kerosene mixtures as a criterion of the water content of the alcohol. He concluded that its sensibility was of the same order as density determinations accurate to the fifth decimal place. Vandam ${ }^{1120}$ in Holland and Andrews ${ }^{1167}$ in this country have also made use of this criterion. The use of this constant promises to be of considerable importance both from the standpoint of convenience and range of applicability in determining the composition of water-alcohol mixtures.

Winkler ${ }^{1087}$ obtained an alcohol of low density, using calcium to remove the water. Klason and Norlin, ${ }^{1109}$ using the same agent after purifying by recrystallization of potassium ethyl sulphate according to recalculation in Table IV, get one result considerably lower than that of Winkler, ${ }^{1087}$ or even the recalculated result of Mendeléeff. ${ }^{207}$ However, the authors state that their results confirm the Windisch ${ }^{685}$ basis, which is recalculated from the results of Mendeléeff, and also confirm the result of Winkler ${ }^{1087}$ as opposed to that of Mendeléeff. These statements can be reconciled with each other and with the results gotten by recalculation, using the thermal expansion formula obtained in part 2, only by the consideration that the authors did not con- 
sider 0.05 per cent water, corresponding to 16 units in the fifth decimal place, as significant. The concordance between Mendeléeff's corrected value and Winkler's value is much better than between the latter and the result of Klason and Norlin. The result given under density $\frac{20^{\circ}}{4^{\circ}}$ calculated to $25^{\circ}$ leaves nothing to be desired when compared with the results of most other investigators. There is some possibility of a misprint in the value at $\frac{15^{\circ}}{15^{\circ}}$. Kailan ${ }^{1148,}{ }^{1341}$ determined the conditions under which lime could be most effectively used as dehydrating agent, and later tried metallic calcium for removing the last traces of water. Andrews ${ }^{1167}$ tested the relative effectiveness of lime, metallic calcium, and magnesium amalgam as dehydrators and obtained alcohols with each that differed only slightly among themselves and were only slightly higher in density than Mendeléeff's ${ }^{207}$ generally accepted value. He used in addition to the density determinations the critical solution temperature and refractive index as criteria of complete dehydration. Extensive work has been done recently in Russia by Doroshevskii 1175,1269 and collaborators on the physical constants of anhydrous alcohol and its mixtures with water. The density value shown in the table was gotten by dehydrating with lime. Among the physical constants considered were specific heat, refractive index, electrical conductivity, vapor pressure, and boiling points. Other alcohols were also studied. The difference in the two density values given for anhydrous ethyl alcohol by this investigator at different times represents 0.04 per cent water.

The determination of the influence of small quantities of water in ethyl alcohol upon the velocity of esterification by $\mathrm{H}$. Goldschmidt and E. Sunde, ${ }^{1101}$ and upon the velocity of other reactions by G. Bredig and W. Fraenkel, ${ }^{1062},{ }^{1090}$ gives some promise of being of value in estimating the small quantities of water. J. Gyr ${ }^{1185}$ has used this influence as a criterion in the dehydration of methyl alcohol. Millar ${ }^{1288}$ and Braune ${ }^{1329}$ regard this method as the best for detecting traces of water in alcohol. In the case of methyl alcohol and the esterification of phenyl acetic acid, assuming the same accuracy of temperature control, the greater accuracy of 
the density determination seems to just about counterbalance the great change in esterification constant for the same percentage of water content. However, the quantitative results are as yet too meager to allow of a certain conclusion in regard to the use of this constant. Kailan ${ }^{1341}$ in a recent work shows the superiority of the density method in one special case. Acree ${ }^{1257}$ and students, in velocity of reaction studies, have used an alcohol showing the same density as that obtained at this bureau. The effect of small quantities of water was small in alkaline solution but very marked in acid solution.

\section{EXPERIMENTAL PART}

\section{OUTLINE OF WORK}

This part of the work has to do with the preparation of chemically pure ethyl alcohol. Experimentally it was proposed: First, to obtain, if possible, using different methods of purification and dehydration, an alcohol showing constant physical properties, even though from different commercial sources; second, to use density determinations as the main criterion of the degree of dehydration and purity with the auxiliary use, in some cases, of the critical solution temperature of its mixtures with kerosene and of such chemical tests as can be applied; third, to obtain, if possible, an alcohol which on further treatment with dehydrating agents would show no decrease in density and no variation in the density of the various distillates from the beginning to the end of a distillation; fourth, to investigate the possible effect on the density of the impurities likely to occur. Aside from considerations having to do with alcoholometry, it was hoped that the additional information gained regarding the most efficient method for preparing pure alcohol, which as a solvent ranks next to water in importance, would be of some importance and value.

Full details of the density determinations are given on page 405 and following.

\section{DETERMINATION OF THE CRITICAL SOLUTION TEMPERATURE}

Alexejew, ${ }^{464}$ Rothmund, ${ }^{859}$ and Timmermans ${ }^{1116}$ have worked extensively with the mutual solubility relations of two liquids. Consider curve III, Fig. r, which represents the solubility relations 
between two components, $\mathrm{A}$ and $\mathrm{B}$, partially miscible in the liquid state, dissolving in each other with an absorption of heat and the final disappearance of one of the liquid phases. The lefthand branch of the curve represents the solubility of $\mathrm{A}$ in $\mathrm{B}$ and the right-hand branch that of $\mathrm{B}$ in $\mathrm{A}$. For constant temperature, below the maximum point of the curve, there are two liquid layers. At the maximum point the two layers become identical in composition. This temperature is called the critical solution temperature, and the concentration at this point is the critical concentration. The point $\times$ represents a divariant system. At the critical concentration and constant pressure the temperature is fixed, depending only on the nature of the components. This critical solution temperature is changed by the addition of a third component $\mathrm{C}$, being fixed for fixed concentration of $\mathrm{C}$. This change in the critical

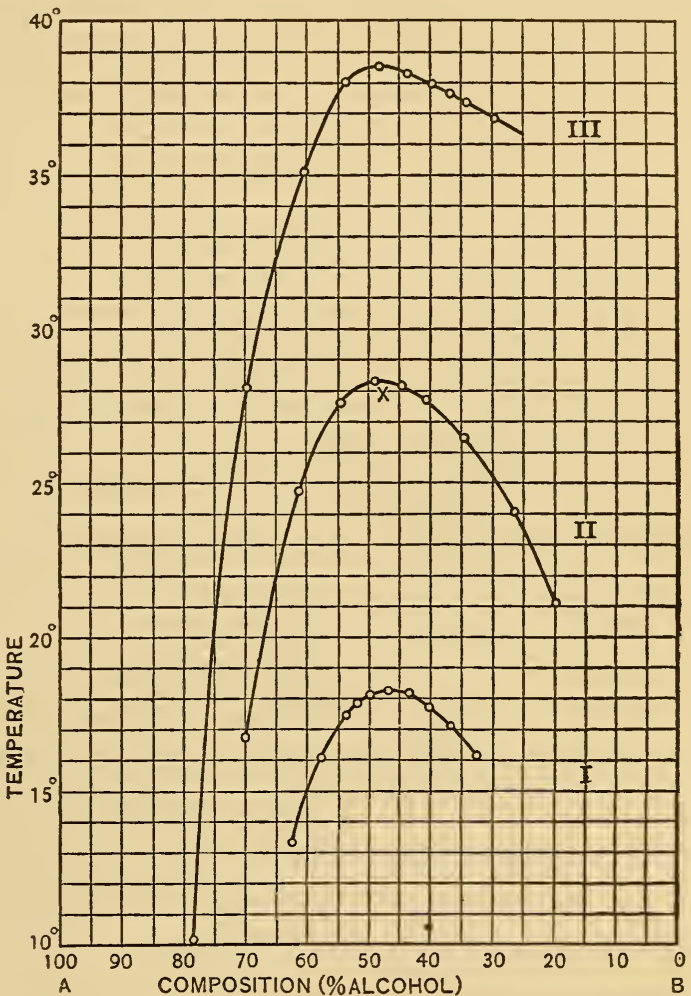

Fig. 1.-Equilibrium diagram for system ethyl alcoholkerosene

solution temperature by the addition of $\mathrm{C}$ has been applied with considerable success to the determination of the purity and composition of organic substances by Crismer, ${ }^{1033}$ Timmermans, ${ }^{1310}$ Andrews, ${ }^{1167}$ and others.

Crismer ${ }^{1033}$ found that the critical solution temperature of a binary mixture of ethyl alcohol and kerosene (considering a given 
kerosene as a component of constant composition) varied so considerably on the addition of water as a third component as to give results comparing favorably with the most careful density determinations for a criterion of the water content of an alcoholwater mixture. This work was later substantiated by Andrews. ${ }^{1167}$ In the present work the results of Crismer were again substantiated and the valuation of this constant for alcohols containing very small amounts of water proved of considerable importance in testing the fractions of several of the distillates. The variation of the critical solution temperature as a function of the amount of water present is given in curves of Fig. 2, with a comparison of our own results with those of Vandam ${ }^{1120}$ and Andrews ${ }^{1167}$ obtained with different kerosenes.

Curve I (Fig. 2) represents the results of Vandam and Curve IV those of Andrews. They are in very good agreement. Curves II and III show the results of the present work. Only mixtures with small amounts of water were investigated. In order to make this physical constant of value over a large range of compositions, it would be necessary to have a series of oils so chosen as to keep the critical solution temperatures within the range of ordinary temperatures most easily observed. The variation for I per cent of water can be read from the curves.

Curves II and III are for oils A and B, respectively (p. 347). The results indicate a large variation of the critical solution temperature caused by small quantities of water, and this variation is independent of the nature of the oil used.

As pointed out by Crismer, the temperature requires to be determined to 0.05 to give the same precision as density determinations to the fifth decimal place, which requires temperature regulation to $0: 01$ or $0: 02$ in making density determinations. As shown in Fig. I, the critical concentration was determined by determining the solubility curves. The maxima of the solubility curves for alcohols containing small amounts of water are not shifted appreciably with respect to the alcohol-oil composition. In Fig. I, considering the concentration of the water as being measured along an axis perpendicular to the plane of the paper, the upper Curve III represents the projection of the real 
solubility curve upon the plane of the paper, which is the zero water plane.

Curve I (Fig. I) shows the solubility curve obtained with oil B and alcohol V-2, a distillate shown in Table X. Curve II represents the solubility relations of oil A and alcohol IX -5 of Table XIII. Curve III gives the curve for oil $\mathrm{A}$ and an alcohol IX-O before dehydration. Since the maximum of the curve is higher than the value given in Table XIII, the sample evidently absorbed

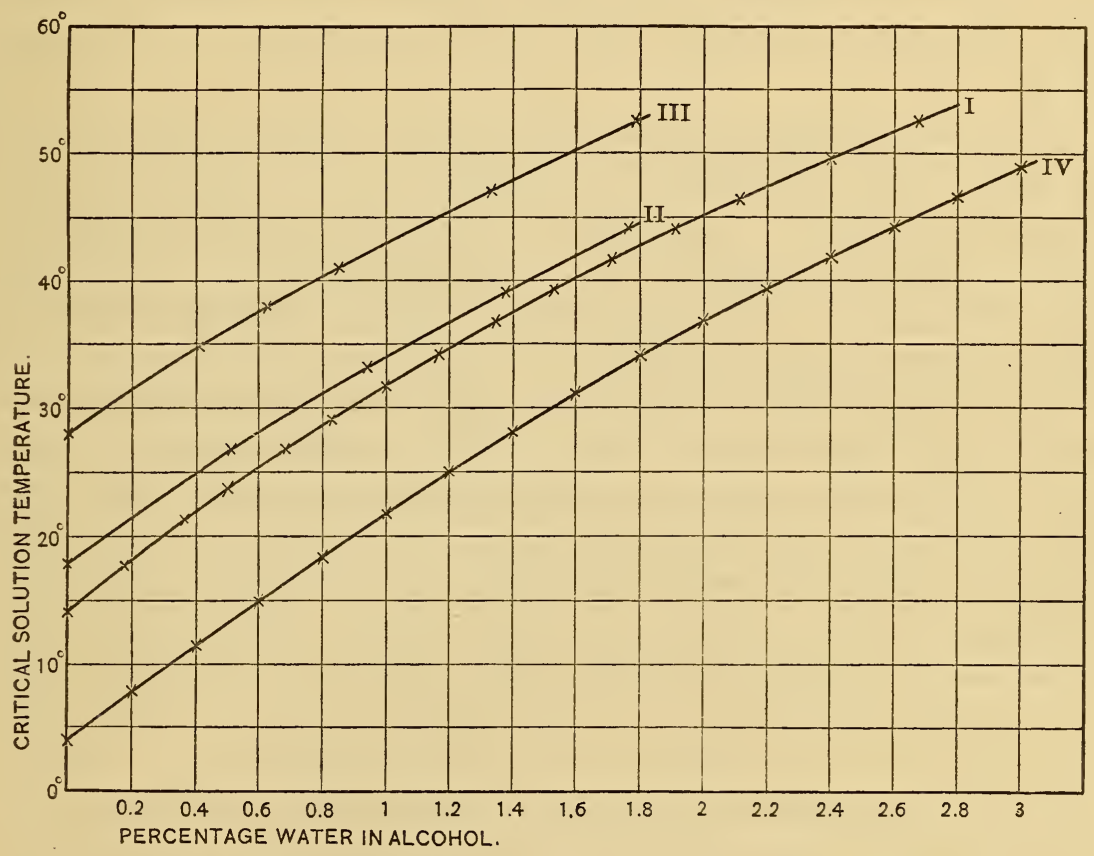

Fig. 2.-Change of critical solution temperature with varying water content of ethyl alcohol

additional moisture during the time between the two determinations.

In the determination of the critical solution temperatures equal volumes (generally $5 \mathrm{cc}$ ) of the alcohol and the kerosene were placed in a small bulb, care being taken to exclude moisture. This was warmed to the region of complete miscibility and slowly cooled in a bath the temperature of which could be varied at any desired rate. At the critical solution temperature there is a 
sharp cloud formation. No difficulty was experienced in repeating observations to $0.05 \mathrm{C}$. In this system there was no disturbing critical opalescence at the critical concentration. In the solubility-curve determinations the end point was not so sharp for the concentrations containing a large percentage of oil.

Kerosene is especially adapted for use as one of the components, since it can be so chosen or changed by mixing with lighter hydrocarbons that the value of the critical solution temperature will be such as to permit convenient temperature measurements. Two kerosenes were used, which will be designated as oil A and oil B.

Oil A had a critical solution temperature with anhydrous alcohol of $28^{\circ} 3$. Slow changes in this value took place when the oil was dried over sodium. It was found that a lower and more constant value could be obtained if the oil were dried over anhydrous ealcium chloride. The changes are probably due to the chemical action of the sodium on the oil.

Oil B was made by diluting oil A with a lower-boiling kerosene. With anhydrous alcohol it gave a critical solution temperature of about $18 \%$. The oil had a density at $25^{\circ}$ of 0.8102 , was dried over anhydrous calcium chloride, and its composition as determined by check determinations with anhydrous alcohol remained unchanged over a period of several months. The preliminary experimental work showed that equal volumes of the two liquids were sufficiently near the critical concentration to permit this concentration to be used for all determinations of the critical solution temperature of alcohols containing very small amounts of water and where the relative values are of most importance. The percentage concentration by weight of alcohol in such a mixture with oil B was 49.2 per cent. Examination of the curves will show this to differ very little from the critical concentration as shown by the maxima of the solubility curves.

In certain of the experiments the values for the critical solution temperature are given in comparison with the density values.

\section{MATERIALS}

Purification and dehydration experiments were made on four samples of alcohol of different commercial origin. These will be 
dєsignated as samples A, B, C, and D. Sample A was purchased from Iler \& Co., The Willow Springs Distillery, Omaha, Nebr., and is known to the trade as "silk-finished spirits." From density determinations, this alcohol showed a percentage strength by weight of 92.8, and it was used in most of the experimental work. An analysis made at this bureau gave the following results:

Aldehydes (as acetic aldehyde) $\ldots \ldots \ldots \ldots \ldots \ldots \ldots \ldots \ldots \ldots \ldots \ldots \ldots \ldots \ldots . . . \%$

Methyl alcohol (Trillat ${ }^{863,} 864$ method and Mulliken and Scudder ${ }^{895}$, 022,1082

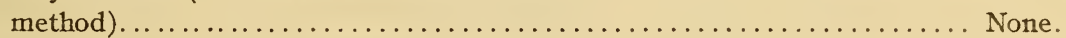

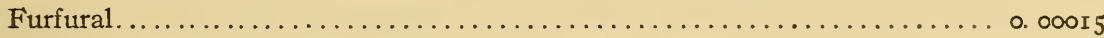

Fusel oil (as amyl alcohol), Allen-Marquardt ${ }^{389}$ method ............. ०. 033

No methyl alcohol was found by the same methods in the first distillate from 4 liters. Methods of analysis of Association of Official Agricultural Chemists ${ }^{1265}$ were used. This analysis shows the sample to have a satisfactory purity for a material with which to start a further extended purification.

Sample B, of approximately the same strength as sample A, was obtained from the Columbia Distilling Co., and showed a satisfactory purity.

Sample C consisted of Squibb's absolute alcohol, having a density of 0.78570 at $25^{\circ} \mathrm{C}$., corresponding to 99.8 per cent on the basis of the Bureau of Standards tables. ${ }^{1216}$ This alcohol was several years old, and qualitative tests showed it to contain considerable aldehyde. It also possessed a foreign aromatic odor.

Sample D consisted of Merck's absolute alcohol Ph. IV, having a density of 0.78705 at $25^{\circ} \mathrm{C}$., corresponding to 99.3 per cent. This sample contained considerable amounts of aldehyde, and was used directly in a final distillation without preliminary dehydration and purification.

\section{PURIFICATION AND TESTING FOR IMPURITIES}

In the preliminary purification attempts to remove the last traces of aldehyde by the method of Winkler ${ }^{1087}$ were unsuccessful, both at ordinary and the boiling temperature. Considerable amounts were removed in this way, but no part of the distillate was found entirely free from aldehyde. No attempt was made to remove the higher boiling impurities other than water, except by rejecting the first and last tenths of the distillates. 
Sample A was treated with silver oxide in alkaline solution under the reflux condenser for several hours and then distilled. Sample B was treated in the same manner in the presence of considerable amounts of lime, in order to dehydrate at the same time. Sample C was treated with silver oxide in alkaline solution at room temperatures, the clear liquid decanted and distilled, and then subjected to the final distillation. In all preliminary dehydrations the great bulk of the impurities were rejected in the first and last tenths of the distillate. With samples A and B it was possible by means of one dehydration with lime, in the proportion recommended by Kailan ${ }^{1148}$ (550 grams per liter), to obtain large quantities of alcohol having a density of $0.7896 \mathrm{r}$ at $20^{\circ} \mathrm{C}$, corresponding, according to the Bureau of Standards ${ }^{1216}$ tables, to 99.9 per cent alcohol by weight. This still contained minute traces of aldehyde, the impurity most easily detected. The method of aldehyde removal with metaphenylenediamine hydrochloride, suggested by Windisch ${ }^{483}$, was not used because of the danger of introducing into the alcohol even more objectionable impurities. The last traces of aldehyde were successfully removed by the method of Paul ${ }^{778}$. The alcohol was boiled for several days under a reflux condenser, coming in contact with nothing other than glass and dry air. The cooling water in the condenser was held at a temperature varying between $50^{\circ}$ and $60^{\circ} \mathrm{C}$. The top of the condenser was provided with an arrangement by means of which the more volatile constituents could be drawn off by means of a current of dry air. This arrangement is shown in Fig. 4. At the end of such a treatment, lasting two days, no more aldehyde could be found in the vapors drawn off and the most delicate tests failed to reveal it in the alcohol. During this procedure the alcohol did not change a determinable amount in density, as shown by determinations made before and after the experiment. There was some indication of aldehyde formation when the aldehyde-free alcohol was exposed to diffused daylight for a few hours. After keeping in the dark for a week, tests showed about as much aldehyde as was present before the treatment.

In general, it seemed that chemical methods for removing aldehyde depending upon its oxidation to the corresponding acid were useless in entirely removing the aldehyde. It seemed hardly 
possible that an agent could be found which would oxidize aldehyde completely without attacking alcohol in the least. Agents such as silver nitrate, silver oxide, and potassium permanganate certainly fail. Metaphenylenediamine hydrochloride is very efficient in case a water-free alcohol is not desired. There has been very little work done on the efficiency of the opposite procedurethat is, reduction of the aldehyde to the corresponding alcohol. According to Wurtz ${ }^{181}$ ethyl alcohol can be prepared by reducing acetaldehyde with sodium amalgam. It was hoped that in the use of aluminum amalgam as a dehydrating agent it would also prove a means of removing the last traces of aldehyde. In view of the consideration that a small quantity of aldehyde is probably formed in the dehydration and in view of the above experiment and additional ones to be given later, showing its small effeet on the density, it was not deemed worth while to make absolutely sure that the dehydration experiments were started with a strictly aldehyde-free alcohol.

In general, the final distillates were tested for the impurities likely to occur, such as aldehydes, the higher alcohols, ether, and water. A brief description of the procedures found most satisfactory follows.

Tests for Aldehydes. - From among the various tests for the lower aldehydes the sulphite-fuchsine reaction was found to be the most senritive and reliable. Ammoniacal silver solution, silver nitrate solution, the Windisch reaction, using metaphenylenediamine, and the Fischer-Penzoldt ${ }^{410}$ test, using diazobenzene sulphonic acid, were not found satisfactory, either because of lack of sensitiveness or of the interfering action of the alcohol itself. The sulphite-fuchsine test as proposed by Schiff ${ }^{209}$ and further developed by Gayon ${ }^{493}$ and Paul ${ }^{778}$ was found fairly satisfactory for small amounts of aldehyde in alcoholic solution. The reagent was made up according to the method of Paul ${ }^{778}$, using sulphurous acid to decolorize the fuchsine, and all tests were made with close adherence to his procedure. The relative results on the aldehyde content of the various fractions are given in some of the experiments. There is, however, some uncertainty as to the absolute amount of aldehyde present. In some fractions it was impossible to get a positive test for this impurity, and it is safe to say that 
in the fractions showing the strongest test the amount of aldehyde was less than 0.001 per cent, and so of neglible effect on the density. Experiments made with water solution of formaldehyde showed that by mearis of this reaction one part in a million could just be detected. The sensitiveness is decreased by the presence of alcohol on account of the uncertain action of pure alcohol itself on the reagent.

Tests for Higher Alcohols (Fusel Oil).-The quantities of any higher alcohols present were so small as to escape detection by any of the ordinary quantitative methods. After the preliminary purification and one distillation no color was given on standing for a week mixed with an equal volume of concentrated sulphuric acid. It wass reasonably concluded that the alcohol was free from higher alcohols in any quantity sufficient to affect the density, outside the limits of the experimental error in its determination.

Other Possible Impurities. - It was considered unlikely that ethyl ether was present, though theoretically a further treatment with a strong dehydrating agent could possibly take from the chemical compound ethyl alcohol $\left(\mathrm{C}_{2} \mathrm{H}_{5} \mathrm{OH}\right)$ the constituents of water, forming the ethyl oxide $\left(\mathrm{C}_{2} \mathrm{H}_{5}\right)_{2} \mathrm{O}$. In the absence of any reliable chemical test for small quantities of ether in the alcohol it was concluded that any appreciable quantity would, on account of its much lower boiling point, show in the first distillate and be recognized both by odor and by a different density. It was deemed unnecessary to consider testing for such unlikely impurities as methyl alcohol and acetone which could not be found in the original samples of alcohol.

Tests for Water.-No specific chemical test for water in such small quantities as they existed in the distillates was found to be of any value. Mendeléeff ${ }^{207}$, ${ }^{241}$ found barium oxide, zinc ethyl, and sodium amalgam unadapted to detect traces of moisture in alcohol. The test with lead-potassium iodide suggested by Biltz ${ }^{1129}$ was found to be inapplicable to alcohol. Such agents as calcium carbide, anhydrous copper sulphate, and metallic calcium gave no indication of water with alcohols whose density at $25^{\circ} \mathrm{C}$ was below 0.785 IO.

The determination of certain physical constants is the most satisfactory test for and criterion of the water content. The only 
objection to such criteria is the necessary assumption of the absence of other substances in quantities sufficient to affect the physical constant determined. Making this assumption then, the determination of physical constants becomes the only satisfactory method for determining quantities of water so small. Since this work has to do with the establishment of a firm basis for density alcoholometric tables, the determination of the density was taken to be the main criterion of the water content.

A detailed description of the methods employed in the density determinations and the data on the determinations which were chosen as establishing the density of absolute alcohol will be found in part 3 of this paper (p. 405). It having been there shown that a knowledge of the condition of saturation of the alcohol with air is essential in order to use density as a criterion of dehydration, the densities given here are for alcohol saturated with air at the temperature of the determination.

Some use was also made of the determination of the critical solution temperature as a second criterion. The best criterion of the attainment of a chemically pure anhydrous ethyl alcohol was the obtaining of a considerable sample, which on further treatment with the same dehydrating agent gave a distillate with the same density from beginning to end of distillation and a value very close to that obtained from various samples of alcohol and by using various efficient methods of dehydration.

\section{DEHYDRATION AND DISTILLATION OF THE ALCOHOL}

Dehydrating agents.-Such reagents as potassium carbonate, sodium amalgam, anhydrous copper sulphate, and calcium chloride were rejected. Calcium carbide was not used because of the possibility of introducing organic impurities impossible to remove. On long contact with alcohol many decomposition products are formed. Lime with the addition of a small quantity of barium oxide was used in an exact duplication of Mendeléeff's ${ }^{207}$, 241 treatment. The larger number of distillations were made with lime alone, using samples as obtained on the market, and also these same after being freshly ignited. Repeated distillation of the same sample of alcohol was made with this reagent. The effciency of metallic calcium was also tested and found satisfactory 
when used in small amounts. Aluminum amalgam was used for the first time in a quantitative test of its efficiency and some of the best alcohol was obtained in this way.

Apparatus and Procedure.-The various distillations were carried out in three types of apparatus. For convenience they will be designated by the letters $L, M$, and $N$. The first type of apparatus, $L$, was used in all preliminary distillations and some of the earlier ones of which the results are recorded. It consisted of a 5-liter Jena flask provided with a 40-cm Hempel still-head filled

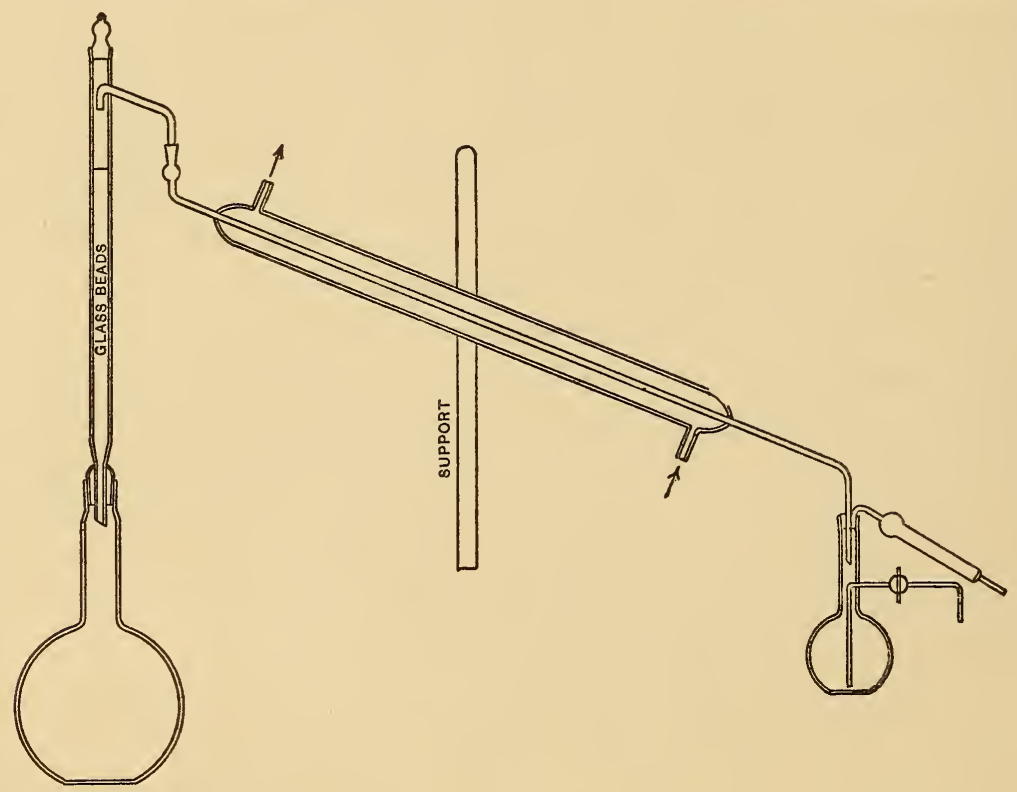

Fig. 3.-Distilling apparatus-Type $N$

with short pieces of glass tubing. To this was connected an $80-\mathrm{cm}$ condenser provided with several interchangeable 500-cc flasks as receivers. These were amply protected from the moist air by means of calcium chloride tubes. The connections between the various parts were made with corks covered with tin foil and there was present the possibility of the introduction of appreciable impurities from these. The second type, $M$, was used in the distillations carried out under reduced pressure. The necessary connecting corks were in this case paraffined and the joints made 
tight by means of mercury seals. The distillations were made from 2 and 3 liter round-bottomed flasks. The pressure could be reduced to $80 \mathrm{~mm}$, giving a boiling temperature of about $40^{\circ} \mathrm{C}$.

The third type, $N$, is shown in Fig. 3. In this apparatus the greatest efforts were made to exclude the possibility of moisture or other impurities being introduced. The still was made entirely of glass, the connecting joints being ground accurately. Distillations were made from 3 - and 5 -liter flasks into the 500-ce receiver. Any fraction of the total distillate under 500 cc could be siphoned off. The entire system was protected from the entrance of moisture by calcium oxide guard tubes. Fig. 4 shows the reflux condenser, used in connection with this apparatus, for the heating of the alcohol with the dehydrating agent and the carrying out of Paul's procedure of removing the aldehyde or other volatile impurities.

All preliminary distillations were made with apparatus $L$, distilling from a water bath varying in temperature between $80^{\circ}$ and $90^{\circ}$. All the distillations carried out with the hope of getting

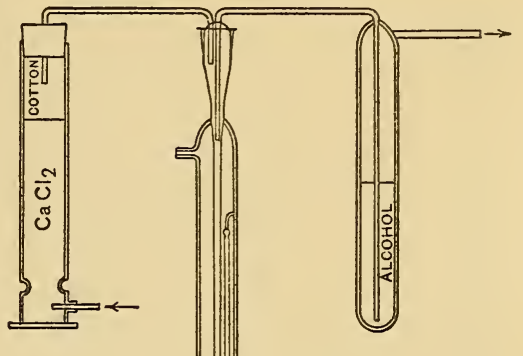
an anhydrous alcohol were made from an oil bath consisting of a high grade and high boiling lubricating oil giving off no appreciable vapors below $1 \mathrm{IO}^{\circ}$. The temperature of this bath, which was heated electrically, varied in the experiments between $80^{\circ}$ and I I $0^{\circ}$.

The following precautions to prevent moisture absorption by the alcohol were taken in all the final experiments of which the results $77398^{\circ}-13-3$ 
are given. In all cases of heating under the reflux condenser the exit was provided with lime or calcium chloride guard tubes or a moving current of dry air. Immediately before putting the still head, with condenser and receiver attached, in place of the reflux condenser, the entire apparatus was swept out for Io minutes by a stream of air thoroughly dried by passing through a calcium chloride drier, sulphuric acid, and over phosphorous pentoxide in succession. The only time during which the vapors of the alcohol came in contact with the outside air was during this transfer, which occupied about five seconds. All retainers for the distillate were swept out in the same way. The various fractions, in case they were not used at once, were always kept in tightly stoppered bottles inclosed in large lime desiccators. The alcohol at no time came in contact with moist air or any glass surface that had not been dried by means of a current of dry air. In a few distillations which will be mentioned small quantities of the dehydrating materials were placed in the still head so that the vapors of the alcohol would come in intimate contact with the same immediately before passing into the condenser. All dehydrating agents were made as nearly anhydrous as possible before any attempt was made to use them. The details of their preparation will be given under the separate experiments to be described.

\section{EXPERIMENTS AND RESULTS}

Fourteen separate dehydrations and distillations were made. These will be designated by Roman numerals. The following outline of the subject matter of their description is given for the sake of clearness. For each of these it is proposed to give-

I. Type of distilling apparatus used, the sample of alcohol used, its density, and, as far as needed, its previous history.

2. The preparation of the dehydrating agent, the treatment of the alcohol in dehydrating, and any special features of the distillation.

3. The results in a tabulated form, giving the number of fractions, their volume, the time occupied in their distillation, and their density at $25^{\circ}$ compared with water at $4^{\circ}$, and the critical solution temperature when determined. Some density values at $15^{\circ}$ will be given. Considering the fact that a change in density 
of 0.000010 corresponds to a temperature change of only 0.012 , the reader will not give undue significance to the sixth decimal place, which is here given for purposes of comparison.

4. A short discussion of the more specialized features and results of a given experiment.

Experiment I.-Three and one-half liters of alcohol from sample A were distilled in apparatus $L$. This alcohol had been dehydrated with lime and showed a density of $0.7896 \mathrm{I}$ at $20^{\circ} \mathrm{C}$. It was also free from aldehydes. On standing for five days, protected from daylight in contact with $700 \mathrm{~g}$ of ordinary commercial lime, it assumed a lemon-yellow color. About roo $\mathrm{g}$ of barium oxide were added and the whole heated under the reflux condenser for ro hours. The alcohol turned a deep brown color. Immediately before the distillation $50 \mathrm{~g}$ of finely powdered lime were added in order to take up any water produced by the too extensive formation of barium alcoholate. This formation of water was shown by Crismer. ${ }^{1033}$ The barium oxide was added merely with the purpose of carrying out one distillation, following as closely as possible the procedure of Mendeléeff. ${ }^{207,}{ }^{241}$ Subsequent experiments show that it can be dispensed with, and it is certainly undesirable to have such extensive reactions, foreign to the purpose of dehydration, going on during the process.

\section{TABLE VI}

Results of Experiment I

\begin{tabular}{|c|c|c|c|}
\hline Sample & Volume & Time & $\mathrm{D} \frac{25^{\circ}}{4^{\circ}}$ \\
\hline 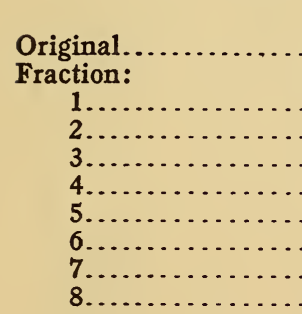 & $\begin{array}{c}c c \\
3500 \\
\\
1000 \\
500 \\
500 \\
350 \\
300 \\
350 \\
250 \\
125\end{array}$ & $\begin{array}{c}\text { hrs } \\
\ldots . \\
9 \\
3 \\
3 \\
2 \\
6 \\
9 \\
2 \\
3\end{array}$ & $\begin{array}{r}0.78535 \\
.785153 \\
.785081 \\
.785066 \\
.785062 \\
.785063 \\
.785061 \\
.785060 \\
.785072\end{array}$ \\
\hline
\end{tabular}

Though the original alcohol used was entirely free from aldehyde, small quantities were found in all the distillates with the 
minimum amounts in the middle fractions. Evidently they were produced during the dehydration process. In no case was the content above o.oor per cent. This experiment is a very satisfactory reproduction of the work of Mendeléeff, the results agreeing with his as to the value of the density, but at the same time showing a much greater uniformity in the various fractions. While the last fraction was being distilled the oil bath was at a temperature of $100^{\circ}$. This fact, in conjunction with later experiments, shows that the temperature of the heating bath has little to do with the composition of the distillates when distilling a nearly anhydrous alcohol, provided it does not exceed $1 \mathrm{IO}^{\circ}$. Within the limits tried the rate of distillation seems to have no disturbing influence. The rate was varied from 40 to I $75 \mathrm{cc}$ per hour without any significant change in the density values.

Experiment II.-Three liters of sample A, having a density of $0.7896 \mathrm{I}$ at $20^{\circ} \mathrm{C}$, after preliminary dehydration, were treated with lime, duplicating as closely as possible the procedure of Messrs. Squibb. ${ }^{433}$ The distillation was carried out in apparatus $M$ under reduced pressure, varying between 80 and $100 \mathrm{~mm}$, necessitating a bath temperature between $35^{\circ}$ and $45^{\circ}$. Air-slaked lime in powdered condition was ignited at a red heat for ro hours and let cool in dry air. This, with some large pieces of freshly ignited lime, aggregating about $400 \mathrm{~g}$ per liter of alcohol, was rotated in the cold for three days and let stand for six weeks with frequent shaking. The clear lemon-colored liquid was siphoned off and distilled.

TABLE VII

Results of Experiment II

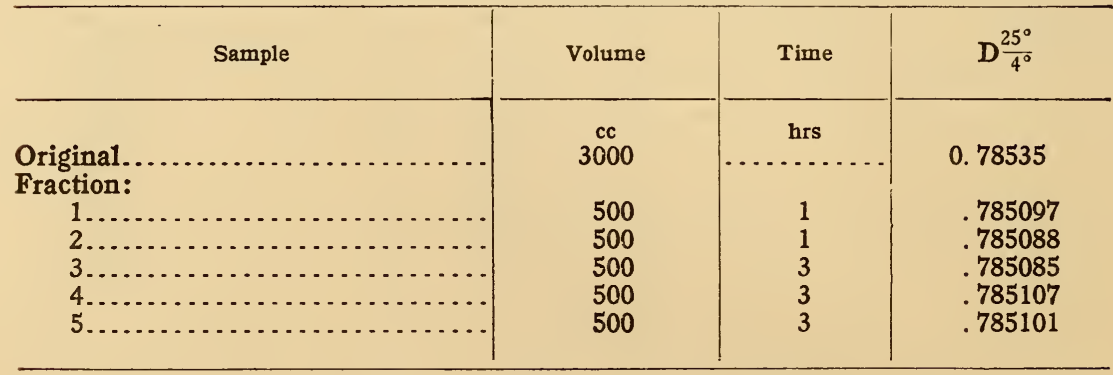

The fractions from this distillation contained traces of aldehyde. By dehydration and treatment essentially similar to that described 
by Messrs. Squibb, it was not possible to duplicate the low values gotten by them for the density of anhydrous alcohol. The values, on the other hand, agree with those obtained by other investigators using a great variety of dehydrating agents. The slightly higher values of all the fractions may be due to their containing less dissolved air.

Experiment III.-One liter of lot C of Squibb's manufacture, after the preliminary purification had reduced the foreign odor and removed the bulk of the aldehyde content, was treated with $400 \mathrm{~g}$ of freshly ignited lime in apparatus $N$. It was subjected to Paul's ${ }^{778}$ treatment in order to remove any of the more volatile constituents still remaining.

TABLE VIII

Results of Experiment III

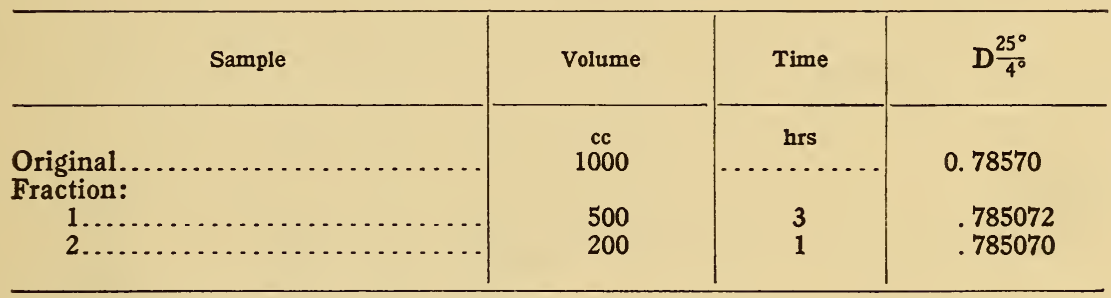

The results of this experiment show the efficacy of Paul's procedure in removing the lower boiling impurities. In the distillates the foreign odor and the aldehyde were just noticeable. The values are very close to what appears to be the normal one.

Experiment $I V$.-This experiment was intended to represent our best efforts in obtaining a pure anhydrous alcohol and was carried out with every precaution that occurred to us. Three and three-tenths liters of mixed distillates from previous experiments were treated in apparatus $N$ with $500 \mathrm{~g}$ of lime made from marble. This lime was ignited for ro hours in an electrical resistance furnace at from $600^{\circ}$ to $700^{\circ}$. After the mixture had been left standing for three days at room temperature, with frequent shaking and after the addition of $25 \mathrm{~g}$ of powdered lime that had been ignited to $900^{\circ}$ for 24 hours, the whole was heated under the reflux for ro hours. The same amount was added immediately before distilling. A considerable quantity of small 
chips, ignited in the same way, was put into the still head and the distillation begun before the alcohol had cooled. Fractions were taken directly from the receiver into the tube in which the density determinations were made. The distillate was so divided into fractions as to show the possible differences in the physical properties of its parts to best advantage.

The results show the distillate to have been very nearly uniform throughout. The density at $25^{\circ}$ of fraction 2 on keeping for several months in a glass-stoppered bottle in a lime desiccator that was frequently opened changed to 0.785088 , representing an absorption of 0.006 per cent moisture, assuming no other changes in the alcohol of such a nature as to influence the density.

TABLE IX

Results of Experiment IV

\begin{tabular}{|c|c|c|c|}
\hline Sample & Volume & Time & $D \frac{25^{\circ}}{4^{\circ}}$ \\
\hline 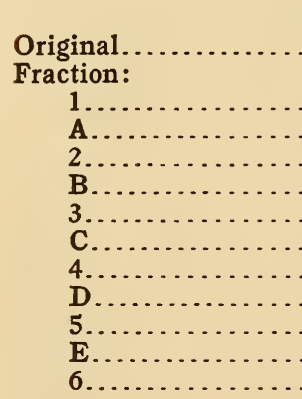 & $\begin{array}{r}c c \\
3300 \\
120 \\
450 \\
120 \\
500 \\
120 \\
350 \\
120 \\
350 \\
120 \\
400 \\
450\end{array}$ & $\begin{array}{r}\text { hrs } \\
0.5 \\
1.5 \\
.5 \\
1.0 \\
.5 \\
.5 \\
.5 \\
1.0 \\
.5 \\
1.0 \\
1.0\end{array}$ & $\begin{array}{r}0.785116 \\
.785097 \\
.785069 \\
.785058 \\
.785056 \\
.785050 \\
.785054\end{array}$ \\
\hline
\end{tabular}

Omitting the density value of the first fraction the various fractions have the same density to within two units in the fifth decimal place.

Experiment $V$.-Four liters of sample B, comprising the middle fractions from the preliminary dehydration and purification, were added to the residues and lime of Experiment IV in the same apparatus.

Heating under the reflux was continued for a week with the water in the reflux between $50^{\circ}$ and $60^{\circ}$. The still head containing the chipped lime was again used. 
TABLE X

Results of Experiment V

\begin{tabular}{|c|c|c|c|}
\hline Sample & Volume & Time & $D^{25^{\circ}}{\frac{10}{4^{\circ}}}^{\circ}$ \\
\hline $\begin{array}{r}\text { Fraction: } \\
1 \ldots \ldots \\
2 \ldots \ldots \\
3 \ldots \ldots \\
4 \ldots \ldots\end{array}$ & $\begin{array}{c}c c \\
400 \\
1000 \\
2100 \\
200\end{array}$ & $\begin{array}{c}\text { hrs } \\
1 \\
3 \\
4 \\
1\end{array}$ & $\begin{array}{r}0.785051 \\
.785101\end{array}$ \\
\hline
\end{tabular}

These distillates contained no aldehyde. They were used in subsequent experiments to test the effect of successive dehydrations and the use of calcium. Freshly ignited lime does not seem to be necessary in order to obtain an alcohol of very low density.

Experiment VI.-The third fraction of $2000 \mathrm{cc}$ from Experiment $\mathrm{V}$ was distilled from apparatus $N$. This alcohol was treated with about $400 \mathrm{~g}$ of commercial lime taken from large pieces and the whole heated under the reflux for 18 hours. The middle fraction of $1250 \mathrm{cc}$ showed a density of $0.78505^{8}$ at $25^{\circ}$.

It appears from this experiment that a repetition of the dehydration even with commercial lime reduced the density of the alcohol product considerably.

Experiment VII.-The middle fraction of Experiment VI was treated with $\mathrm{r} 5 \mathrm{O} \mathrm{g}$ of chipped lime that had been ignited at $900^{\circ}$ for io hours. This was heated under the reflux for 18 hours and then distilled in apparatus $N$.

TABLE XI

Results of Experiment VII

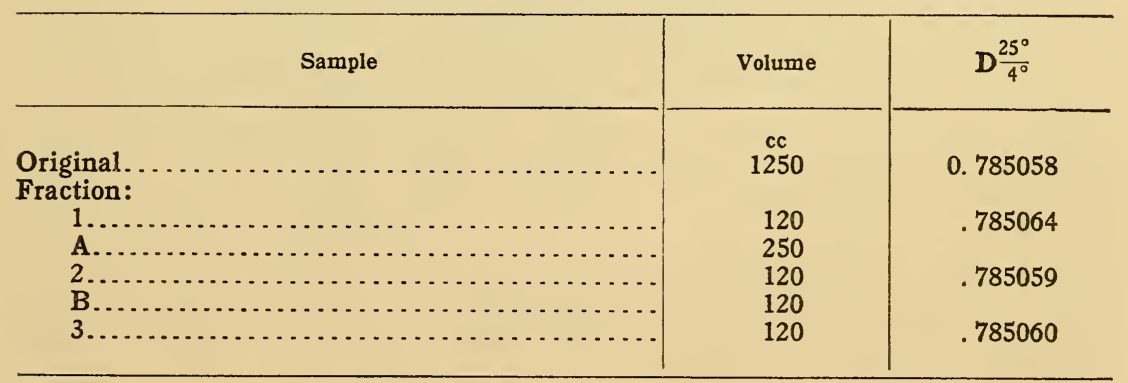


This is the final of three successive dehydrations of the same sample of alcohol with lime. The value remains essentially unchanged and the separate fractions show a remarkable agreement in their densities, indicating the purity and uniformity of the alcohol. It seems that this distillate represents the best results obtainable with lime as a dehydrating agent, and also from the standpoint of uniformity of the different parts of the distillate. It is probable that this alcohol is freer from impurities than any obtained in this work with the possible exception of the distillates of Experiment XII.

Experiment VIII.-The combined fractions from Experiment VII, aggregating about $75^{\circ} \mathrm{cc}$, were treated in apparatus $N$, with $6 \mathrm{~g}$ of metallic calcium and let stand over night. The calcium acted upon the alcohol with hydrogen evolution giving a white crystalline alcoholate, which went into solution on raising the temperature.

\section{TABLE XII}

Results of Experiment VIII

\begin{tabular}{|c|c|c|c|}
\hline Sample & Volume & Time & $\mathrm{D}^{25^{\circ}}$ \\
\hline $\begin{array}{r}\text { Original....... } \\
\text { Fraction: } \\
1 \ldots \ldots . . \\
2 \ldots \ldots \ldots \\
3 \ldots \ldots \ldots\end{array}$ & $\begin{array}{l}c c \\
750 \\
250 \\
250 \\
200\end{array}$ & $\begin{array}{l}\mathrm{hrs} \\
\cdots \\
3 \\
1.5 \\
2\end{array}$ & $\begin{array}{r}0.785061 \\
.785081 \\
.785072 \\
.785080\end{array}$ \\
\hline
\end{tabular}

The table shows a slight increase in the density results. This can not be certainly ascribed to an increase in the water content. It may easily be due to a variation in the condition with regard to air saturation caused by the calcium treatment or to the formation of a small quantity of some other substance. The residues in the flask were brownish. The distillation was carried almost to dryness. Other investigators have found smaller amounts of calcium more efficient than large amounts. The value obtained for the density by use of this agent is lower than that obtained by other investigators, excepting Klason and Norlin.1109 Results indicate that lime is more efficient than metallic calcium. 
Experiment IX.-Four liters of sample D without preliminary dehydration and purification were treated with $400 \mathrm{~g}$ of recently ignited lime per liter of alcohol. This was let stand for several weeks with frequent shaking. As in the other cases of dehydrating with lime, a lemon yellow color appeared, deepening finally to a brown. No attempt was made to remove the aldehyde by chemical means. The whole was subjected to Paul's 778 treatment of boiling under the reflux for about two days. Distillation was carried out in apparatus $N$ after adding about $25 \mathrm{~g}$ of freshly ignited powdered lime.

TABLE XIII

Results of Experiment IX

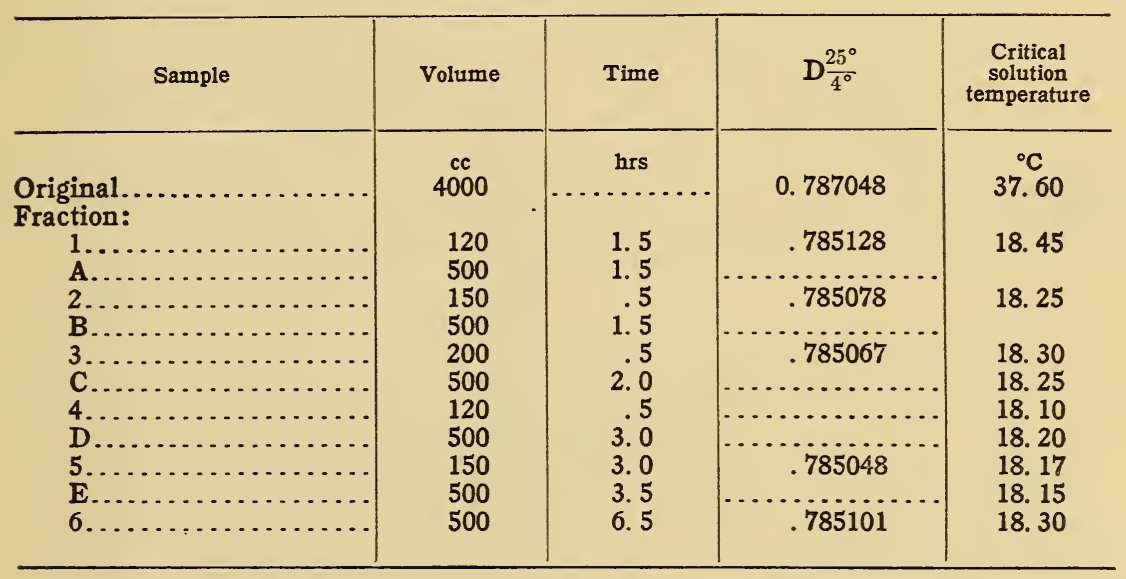

In the last column are given the values of the critical solution temperature. The relative values of this constant found for the different fractions are somewhat irregular, but in general follow the density values. By one dehydration with lime of a commercial absolute alcohol as above it is possible to get a middle portion of the distillate showing the density value of anhydrous alcohol. This alcohol from a different commercial source furnishes anhydrous alcohol of essentially the same physical properties as the other samples examined.

Experiment $X$.-The three following experiments were made, using activated aluminum (aluminum amalgam) as dehydrating agent. There are several statements in the literature regarding its efficacy, but no quantitative experimental data. 
One liter of sample $A$, having a density of 0.78535 at $25^{\circ}$, after the preliminary dehydration, was treated with $10 \mathrm{~g}$ of aluminum amalgam. The distillation was carried out in apparatus $M$ under reduced pressure. The amalgam was prepared as recommended by Wislicenus and Kaufmann ${ }^{750}$ by etching aluminum wire with sodium hydroxide solution and then treating with a dilute solution of mercuric chloride. The amalgam, after washing with alcohol and ether and subsequent drying, was let stand with the alcohol over night. There was an abundant formation of the insoluble alcoholate with copious hydrogen evolution.

TABLE XIV

Results of Experiment $\mathrm{X}$

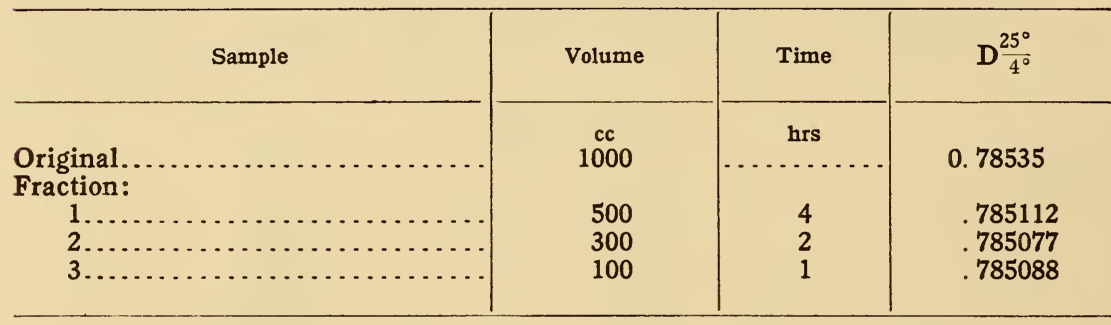

Twenty cubic centimeters of fraction 2 were added to fraction 3 to give sufficient volume for the determination of the density.

Experiment XI.-One liter of the same sample as used in the previous experiment was treated with ro $\mathrm{g}$ of amalgam and let stand for three weeks. This amalgam was made by heating the wire in mercury up to the boiling point of the latter. The distillation was carried out in apparatus $M$ under reduced pressure. After rejecting the first $50 \mathrm{cc}$ the middle fraction of $400 \mathrm{cc}$ showed a density, at $25^{\circ}$, of 0.785089 .

Experiment XII.-Two and one-half liters of sample A, after preliminary purification, were treated with amalgam made from $25 \mathrm{~g}$ of aluminum wire. The alcohol was kept boiling for a week under a reflux condenser containing water varying in temperature between $50^{\circ}$ and $60^{\circ}$. No aldehyde was contained in the vapors drawn off at the end of this treatment. Immediately before distilling in apparatus $N$ some freshly amalgamated wire was placed in the still head. 
TABLE XV

Results of Experiment XII

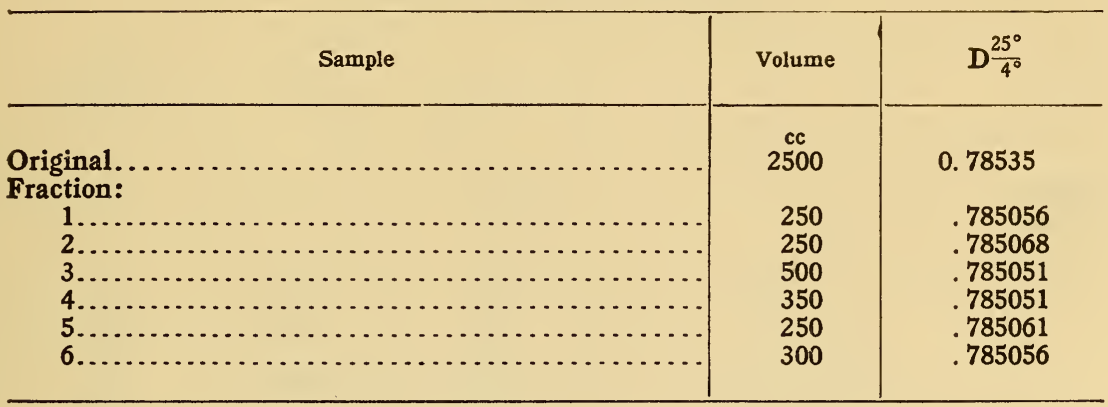

The alcohol obtained in this experiment represents a pure liquid within the limits set by the sensitiveness of the density determination as a criterion of purity. The density results agree very closely with those obtained by other methods of dehydration. All the fractions were practically free from aldehyde. The amalgam may act as a reducing agent, converting aldehyde into the corresponding alcohol or at least preventing any formation of aldehyde during the dehydration.

Experiment XIII.-In order to furnish anhydrous alcohol for a check series of density determinations of mixtures given in part 4 , two additional distillations were made.

Two liters of a mixture made from fractions of various distillations of lots A and B (IV, I; V, 4; VI, I ; XII, I, 6) were treated with $200 \mathrm{~g}$ of freshly ignited lime. The alcohol was let stand for Io days with frequent shaking. The clear liquid was siphoned off with careful exclusion of moist air and treated under the reflux condenser for a day after adding $50 \mathrm{~g}$ of freshly ignited, airslaked lime which was in a very fine state of division. The water in the reflux was held at about $60^{\circ}$ and the more volatile constituents were removed by means of a moving current of dry air led into the top of the condenser. Fifty grams additional of powdered lime were added immediately before distilling. Apparatus $N$ was used with the receiver directly sealed to the condenser. The densities of the various fractions were determined at $15^{\circ}$ in order to give a direct comparison with the results of Mendeléeff. The critical solution temperature was followed closely. 
TABLE XVI

Results of Experiment XIII

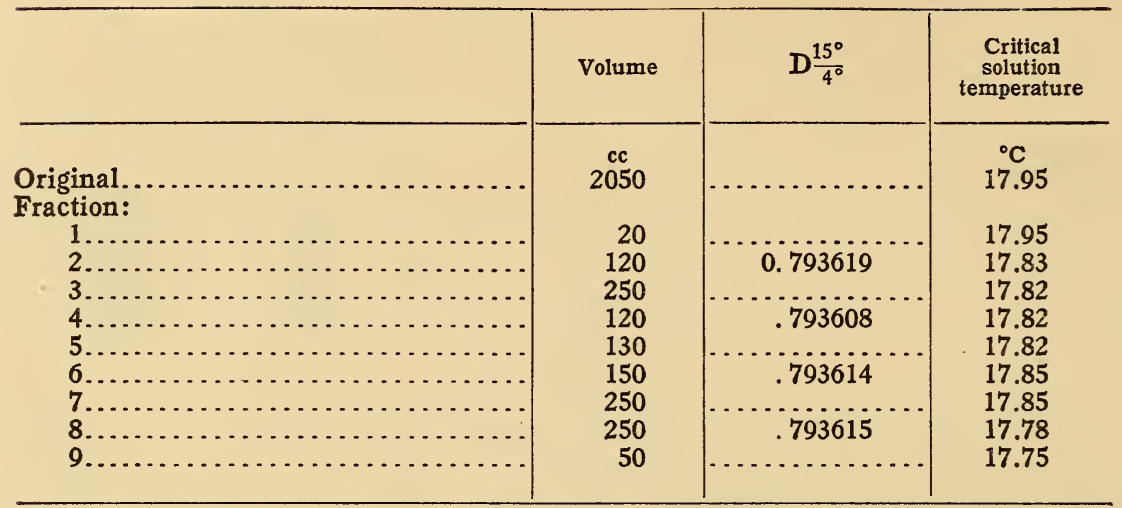

Fraction 4 near the middle of the distillate shows the lowest density. The critical solution temperature showed a small decrease as the distillation proceeded and indicated a decreasing water content on the assumption of the absence of other impurities. The differences are hardly significant and the results show a satisfactory agreement with the other experiments. The density of absolute alcohol at $15^{\circ}$ is somewhat higher than the corrected result of Mendeléeff.

Experiment $X I V$.-Fractions from the various distillations $(\mathrm{V}, 2$; IX, 2, 6, C; XIII, 2, 4, 8, 9) were combined and treated with lime as given under Experiment XIII. The same distilling apparatus was also used. Density determinations were made at I $5^{\circ}$ and $25^{\circ}$.

\section{TABLE XVII}

Results of Experiment XIV

\begin{tabular}{|c|c|c|c|}
\hline Sample & $D \frac{15^{\circ}}{4^{\circ}}$ & $\mathrm{D} \frac{25^{\circ}}{4^{\circ}}$ & $\begin{array}{c}\text { Critical } \\
\text { solution } \\
\text { temperature }\end{array}$ \\
\hline 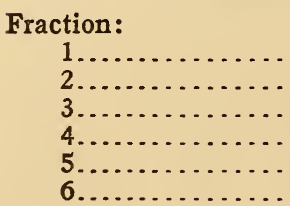 & $\begin{array}{r}0.793596 \\
.793595\end{array}$ & $\begin{array}{r}0.785049 \\
.785058\end{array}$ & $\begin{array}{l}{ }^{\circ} \mathrm{C} \\
17.10 \\
17.10 \\
17.10 \\
17.05 \\
17.05\end{array}$ \\
\hline
\end{tabular}


Judging from the results obtained in the determination of the critical solution temperature, there is practically no separation of the alcohol into fractions of different physical properties. The densities obtained are slightly below the mean values obtained in the previous experiments. It is interesting to compare the expansion of fractions 3 and 4 between $15^{\circ}$ and $25^{\circ}$ with the value called for by the formula obtained in part 2. Here the value for $D_{4^{\circ}} \frac{15^{\circ}}{4^{\circ}}-D_{4^{\circ}}{ }^{\circ}$ is found to be 0.008547 for fraction 3 and 0.008537 for fraction 4 , while the formula difference is 0.00854 .

\section{EFFECT OF IMPURITIES ON THE DENSITY}

A study was then made of the effect of small concentrations of possible impurities on the density of anhydrous alcohol and on the critical solution temperature with kerosene mixtures. The effect of acetaldehyde and ethyl ether was studied. Some data were also obtained on the effect of dissolved air. (See p. 407.)

The lower aldehydes, principally acetaldehyde, are the most persistent impurities in alcohol, notwithstanding their much lower boiling points. While tests showed that acetaldehyde was not present in amounts sufficient to affect the density appreciably, yet it was deemed worth while to determine the direction and amount of this effect. Acetaldehyde was made by oxidizing alcohol with chromic-sulphuric acid mixture, then purified and dehydrated by distilling twice from anhydrous calcium chloride. Immediately before making the mixtures the vapor was passed over calcium chloride before condensation. The mixtures were made up by weighing directly. Table XVIII shows the results obtained.

TABLE XVIII

Effect of Acetaldehyde on Density

\begin{tabular}{c|c|c|c}
\hline \multicolumn{1}{c|}{ Mixture } & Acetaldehyde & $\mathrm{D}^{25^{\circ}}$ & $\begin{array}{c}\text { Increase in } \\
\text { density }\end{array}$ \\
\hline Anhydrous alcohol $\mathrm{XI}_{3} \ldots \ldots \ldots \ldots \ldots$ & $\begin{array}{c}\text { Per cent } \\
0.00\end{array}$ & 0.785101 & 0.000000 \\
1 & .023 & .785144 & .000043 \\
3 & .140 & .785394 & .000293 \\
3 & .466 & .786030 & .000929 \\
\hline
\end{tabular}


The aldehyde in mixture 2 could be plainly recognized by odor. Mixture I diluted with alcohol to ro times its volume still gave a strong test for aldehyde by means of the sulphite-fuchsine reaction. Ramsay ${ }^{338}$ found $0.777 \mathrm{I}$ to be the density of acetaldehyde at $2 \mathrm{I}^{\circ}$, this temperature being its boiling point. Small variations of the density of the fractions in certain experiments may be due to small quantities of aldehyde. It may be interesting to note the concordance in the various fractions of Experiment XII where aluminum amalgam was used as dehydrating agent and might act as a reducing agent converting the aldehyde into alcohol. One per cent aldehyde lowers the critical solution temperature $0: 5$.

Very small quantities of ether are not open to detection by chemical means because of its resistivity toward chemical reagents in general. One would expect the bulk of any ether present to collect in the first fraction on distillation and to be recognizable either by odor or its effect on the density or other physical properties. A few mixtures of known ether content were made up and their density determined. The ether was purified by shaking with dilute sodium hydroxide solution and then washed thoroughly with water to remove the alcohol. After several days' drying over anhydrous calcium chloride it was distilled from sodium wire immediately before use. The mixtures were made up by direct weighing.

\section{TABLE XIX}

Effect of Ethyl Ether on Density

\begin{tabular}{|c|c|c|c|}
\hline Mixture & Ether & $\mathrm{D} \frac{25^{\circ}}{4^{\circ}}$ & $\begin{array}{l}\text { Change } \\
\text { in } \\
\text { density }\end{array}$ \\
\hline $\begin{array}{c}\text { Anhydrous alcohol, } \mathrm{IV}_{5} \text {. } \\
1 \\
2\end{array}$ & $\begin{array}{c}\text { Per cent } \\
0.00 \\
.060 \\
.185\end{array}$ & $\begin{array}{r}0.785091 \\
.785070 \\
.785019\end{array}$ & $\begin{array}{l}-0.000021 \\
-.000072\end{array}$ \\
\hline
\end{tabular}

For small amounts of ether in alcohol the results show that o.I per cent lowers the density 0.00004 . Both mixtures on standing gave a strong odor of ether. Young ${ }^{988}$ suggests the possibility that the low density results obtained by Messrs. Squibb ${ }^{433}$ may be due to the presence of ether. Assuming the same rate of 
decrease to hold and taking 0.78506 as the correct value for the density of anhydrous alcohol at $25^{\circ}$, it would take approximately 0.9 per cent ethyl ether to give their low value. This amount could hardly escape detection. One per cent ether lowers the critical solution temperature $2: \mathrm{I}$.

\section{DISCUSSION OF RESULTS}

The distillates obtained in Experiments IV and XII answer all the requirements as to purity, judged by the constancy of the physical property determined. That they were not mixtures showing constant physical properties is indicated from the fact that the density results agreed even when different dehydrating agents were used. That the density of the distillate remained essentially unaltered when the distillation was carried on under reduced pressure is additional evidence on this point.

Concerning the freedom from impurities other than water in the distillates showing densities, at $25^{\circ}$, of $0.78506 \pm 0.0000 \mathrm{I}$, the following is to be said: (I) The fact that fractions of the same density were obtained from samples of different origin points to either a removal of all the significant amounts of impurities or a retention of these impurities in fixed amounts even though using different methods of purification; (2) the good agreement found in the density of the mixtures made up from the distillates and mixtures of distillates with densities showing water content from o.or to 0.05 per cent, and from different alcohols, indicates a uniformity in the alcohol characteristic of a pure substance within our present methods of determination.

\section{SUMMARY OF RESULTS}

I. No difficulty was experienced in obtaining alcohol containing only one-tenth of I per cent of water by dehydrating with lime. The dehydration proceeded more rapidly at the boiling temperature of the alcohol. The bulk of the impurities other than water were removed by the rejection of the first and last tenths of the distillate in the preliminary distillation.

2. Chemical methods for removing the last traces of the lower aldehydes were found to be unsatisfactory. This was accomplished by the method of Paul. ${ }^{778}$ Results indicated that minute quan- 
tities of aldehydes are produced during the procedure of dehydration and distillation. These quantities can just be detected chemically and were so small as to have no measurable effect on the physical constants determined.

3. An alcohol was obtained which on a further dehydration was not lowered in density and on distillation gave fractions showing the same density within the experimental errors of the determination. Practically the same density value, 0.78506 at $25^{\circ}$, was obtained by using calcium oxide and activated aluminum, and this value is only slightly lower than the results of the more careful previous experimenters. The two dehydrating agents mentioned were equally satisfactory in removing the last traces of water. Slightly higher density values were obtained when calcium was used.

4. By a repetition of Mendeléeff's ${ }^{207,}{ }^{241}$ procedure used in dehydrating alcohol a distillate showing about the same density value was obtained. The various fractions of the distillate showed greater uniformity in density than in his work. A repetition of the work of Messrs. Squibb in its essential details failed to produce alcohol showing the same low density values obtained by them.

5. Small amounts of acetaldehyde increased, while small amounts of ether decreased the density of ethyl alcohol. It was shown that Squibb's ${ }^{433}$ low density values can not be ascribed to the presence of ethyl ether.

6. In substantiation of the work of Crismer ${ }^{1033}$ and Andrews ${ }^{1167}$ the value of the critical solution temperature as a method for detecting small amounts of water in alcohol was demonstrated and shown to have approximately the same sensitiveness as density determinations to one unit in the fifth decimal place. 


\title{
PART 2
}

\section{THERMAL EXPANSION OF MIXTURES OF ETHYL ALCOHOL AND WATER}

\author{
By N. S. Osborne
}

Part 2 consists of the determination of the thermal expansion between $10^{\circ} \mathrm{C}$ and $40^{\circ} \mathrm{C}$ of 12 mixtures of alcohol and water, and the derivation of the coefficients for calculating, between these limits of temperature, the density of any mixture of alcohol and water.

\section{DESCRIPTION OF EXPERIMENTAL WORK}

\section{METHOD OF DETERMINATION AND GENERAL DESCRIPTION OF APPA- RATUS}

Twelve mixtures whose thermal expansions were investigated were made of approximately integral percentages for convenience, and the concentrations chosen were such as would facilitate interpolation of results. The density of each mixture was twice determined at each of the following temperatures: $10^{\circ}, 15^{\circ}, 20^{\circ}$, $25^{\circ}, 30^{\circ}, 35^{\circ}$, and $40^{\circ} \mathrm{C}$, one series starting with the lower and one with the higher temperature. The density determinations were made by the hydrostatic weighing method-that is, by weighing in the liquid a sinker of known mass and volume.

The arrangement of apparatus is shown in Figs. 5, 6, 7, and 8. The densimeter tube containing the liquid under investigation and the immersed sinker $E$ is shown in Fig. 5. A special cap was used for closing the densimeter tube when weighings were not being made. This cap consists of a brass cover "a," fitted to the tube by a soft rubber bushing. Through the center of the cover is a hole, which may be closed by a tightly fitting brass plug. To the upper and lower faces of this plug is attached the suspension wire. The arrangement is shown in Fig. 5. When weighings are in progress, the suspension is as shown at the right, access of the outer air being only through the hole in the cap. When not

$$
77398^{\circ}-13-4
$$



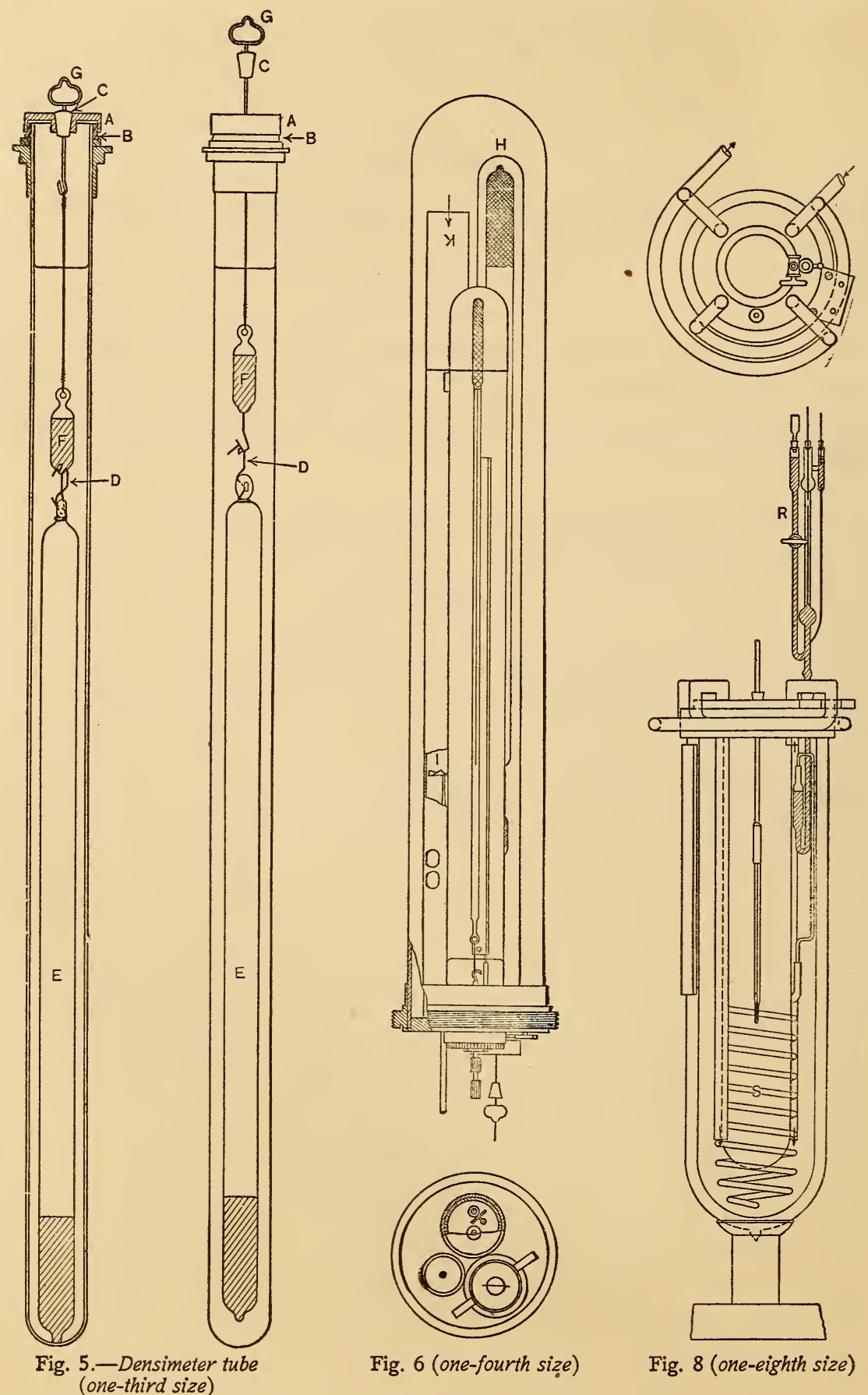

Fig. 6 (one-fourth size)

Fig. 8 (one-eighth size) 
observing, this hole is closed by the plug, as shown at the left, in order to avoid unnecessary changes in concentration of the liquid, caused by evaporation of the alcohol or by absorption of water vapor from the air. In Figs. 6 and 7 the densimeter tube $H$ is shown fixed in place in the inner water bath.

The water in the inner bath is kept in constant circulation by the propeller $I$. This bath is immersed in an outer bath kept in constant circulation by means of a motor-driven turbine $N$ placed outside the bath. The temperature of this outer bath is maintained constant or changed at will by means of the electric heating coil $O$ surrounding the return pipe and by the tubular coil $P$ connected with the refrigerating brine supply maintained at a temperature below $0^{\circ} \mathrm{C}$. The flow of brine in this coil is adjusted by means of a valve, not shown. The flow of water in the circulating apparatus may, by means of the special valve $Q$, be directed entirely through the cooling chamber, directly through the circulating turbine, or divided, part going either way at will, thus regulating the quantity of heat removed from the system by the brine. The cooling is made slightly in excess of the heat acquired from the surrounding air and that produced by the circulation, the balance being maintained by means of the heating coil.

This coil, which has a resistance of Io ohms, is made of "advance" ribbon, wound over mica on the brass tube through which the return flow takes place. It is used both for regulation of temperature and for rapid heating when changing the temperature. For regulation it is connected in series with a variable resistance composed of a sliding contact wire rheostat and a bank of parallel connected lamps. As a shunt on this variable resistance is connected another lamp bank in the circuit of which is a relay operated by the thermo regulator $R$. The bulb of this thermo regulator is the tubular copper coil $S$, containing about $40 \mathrm{cc}$ of xylol.

A rise in temperature closes an electric circuit, the relay is thus energized, the shunt circuit broken, and the current in the heating coil diminished. When the temperature falls sufficiently, this action is reversed. The sensibility of the regulation varies according to the conditions. Under the most adverse conditions the regulating energy used in the heating coil was from roo watts 
to I 40 watts and maintained the outer bath constant within $0^{\circ} .05 \mathrm{C}$. Under the best conditions the energy varied from ro to 20 watts, keeping the temperature of the bath constant within $0^{\circ}$.or C. The periodic variation in temperature of the outer bath was in either case far too rapid to produce any perceptible change in the inner bath. For rapid heating when changing the temperature in the ascending series, the small regulating current was replaced, using a double-throw switch, by a heavy current supplying about 1500 watts in the heating coil.

The outer bath as first arranged is shown in Fig. 7. It is contained in a rectangular tank with plate-glass walls and brass bottom and top. The insulation consisted of two layers of heavy cardboard with cotton between. The water enters at $T$ and leaves at $U$, thus insuring complete circulation. Owing to the repeated difficulty on account of leakage of the joints, this tank was replaced by a double-walled glass cylindrical vacuum jacket as shown in Fig. 8. The top was closed by a brass cap cemented to the glass. The water entered by two tubes extending to the bottom and left by two tubes at the top. The greatest difficulty, with this container for the outer bath was the distortion of the image of the thermometers, owing to the cylindrical surface. This was remedied by cementing a plane glass plate to the outside surface, forming a cell which when filled with water corrected most of the aberration. To exclude radiation the cylinder was covered with nickel paper. This vacuum jacket was used principally for the determinations of density of the mixtures of known proportions at constant temperature and was employed for the thermal expansion of only one mixture, 5 III.

The temperatures were observed on two mercury thermometers suspended in water in a tube placed in a position in the inner bath symmetrical to that of the densimeter tube. On Fig. 8 only the upper part of this tube is shown. The holders for the thermometers permitted their rotation and also allowed either of the two to be brought into position for reading. They were read by means of a microscope of long focus which could be moved vertically by means of a rack and pinion.

The reason for placing the thermometers in a tube of water instead of directly in contact with the inner bath was to minimize 


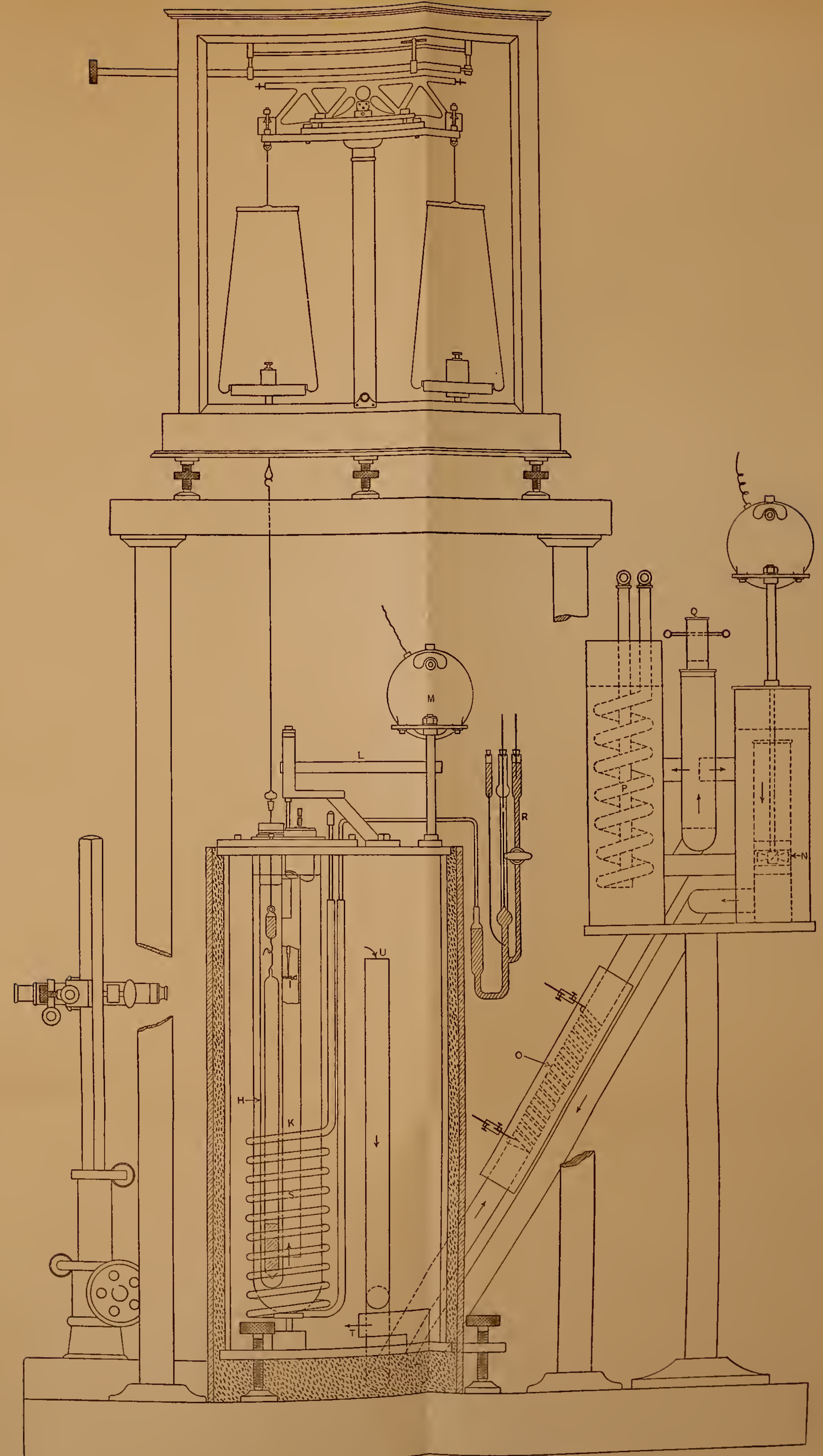

Fig. 7.-Apparatus for determinotion of acnsity ano inemal exponsion lonc-sixth size,

-7395-13. (To fa:e page 3i4.) 
the error from temperature lag when bringing the temperature to constancy before observing. The containing tube was slightly larger and thicker walled than the densimeter tube; hence when the thermometers indicated a constant temperature it could be assumed that the liquid in the densimeter tube was at the same constant temperature. In the observations for thermal expansion economy of time did not permit an absolutely constant temperature to be attained, but the observed variation during a density observation extending over about six minutes never exceeded $0^{\circ} .02$ and, with but few exceptions, was always rising. Thus the relative error due to lag in the temperatures of the determinations was small, probably less than $0^{\circ}$.or except in few instances, and may be regarded as accidental and eliminated in the adjusted results. Examinations of the residuals obtained justifies this assumption.

\section{THERMOMETERS USED}

Five thermometers were used in this work; they are described in Table XX.

TABLE XX

\begin{tabular}{|c|c|c|c|c|c|c|}
\hline $\begin{array}{l}\text { Ther- } \\
\text { mome- } \\
\text { ter No. }\end{array}$ & Maker & $\begin{array}{l}\text { Date of } \\
\text { manu- } \\
\text { facture }\end{array}$ & Kind of glass & Range of scale & $\begin{array}{l}\text { Length } \\
\text { of } 1^{\circ}\end{array}$ & Construction \\
\hline 4653 & Tonnelot.. & 1888 & Verre durre.. & $-2^{\circ} .9 \mathrm{C}$ to $+40^{\circ} .5 \mathrm{C}$. & $\underset{6.3}{\mathrm{~mm}}$ & Solid, clear stem \\
\hline 2040 & Haak. & 1906 & Jena $16^{\mathrm{III}}$ & $\left\{\begin{array}{l}-1 \text { to }+1^{\circ} \mathrm{C} \ldots \ldots \\
+10 \text { to }+31^{\circ} \mathrm{C} \ldots\end{array}\right.$ & 4. 8 & $\left\{\begin{array}{c}\text { Inclosed, w h it e } \\
\text { scale }\end{array}\right.$ \\
\hline 264 & Richter... & 1902 & do & $\left\{\begin{array}{l}-0.4 \text { to }+0^{\circ} .4 \mathrm{C} \ldots \\
+31.5 \text { to }+44^{\circ} \mathrm{C} \ldots\end{array}\right.$ & 8.0 & Do. \\
\hline 2499 & Green. & 1907 & ..do. & $\left\{\begin{array}{l}-0.5 \text { to }+0^{\circ} .5 \mathrm{C} \ldots . . \\
+9 \text { to }+31^{\circ} .5 \mathrm{C} . \ldots .\end{array}\right.$ & 7.5 & $\left\{\begin{array}{c}\text { Solid, white back } \\
\text { stem }\end{array}\right.$ \\
\hline 15938 & Baudin.. & 1903 & Verre durre.. & $\left\{\begin{array}{l}+31.5 \text { to }+32^{\circ} .5 \mathrm{~F} \\
+89.1 \text { to }+115^{\circ} .6 \mathrm{~F}\end{array}\right.$ & 7.2 & Do. \\
\hline 15940 & .....do. & 1903 & ....do. & $\left\{\begin{array}{l}+31.5 \text { to }+32.0^{\circ} 5 \mathrm{~F} \\
+88.9 \text { to }+115^{\circ} .8 \mathrm{~F}\end{array}\right.$ & 7.2 & Do. \\
\hline
\end{tabular}

All the thermometers were subdivided in tenth-degree divisions. No. 4653 was repaired in 1909 and the bulb reannealed. This thermometer was used in all of the experimental work at every temperature. Nos. I 5938 and I 5940 were used only for the thermal expansion of 5 III at $35^{\circ}$ and $40^{\circ} \mathrm{C}$. For this same mixture No. 2499 was used at $10^{\circ}, 15^{\circ}, 20^{\circ}, 25^{\circ}$, and $30^{\circ} \mathrm{C}$. For the ther- 
mal expansion of all the other mixtures No. 2040 was used at $10^{\circ}$, I $5^{\circ}, 20^{\circ}, 25^{\circ}$, and $30^{\circ} \mathrm{C}$, and No. 264 was used at $35^{\circ}$ and $40^{\circ} \mathrm{C}$. Every temperature was observed on two thermometers, one always being No. 4653 .

The thermometers were calibrated at the points $10^{\circ}, 15^{\circ}, 20^{\circ}$, $25^{\circ}, 30^{\circ}, 35^{\circ}$, and $40^{\circ} \mathrm{C}$ by comparison with the primary mercurial standards of the bureau. In the use of the thermometers their ice points were observed after the determination at each temperature, and the corrections to be applied to the observed temperature were deduced from the ice point reading and the calibration corrections. The corrected temperatures are in accordance with the international hydrogen scale.

\section{DESCRIPTION OF SINKER}

The sinker used in all hydrostatic weighings in this article is designated No. 7. It is made of Jena $16^{\mathrm{III}}$ glass. The length over all is $33 \mathrm{~cm}$; the outside diameter is $13 \mathrm{~mm}$. The platinum hook $D$, weighing $0.5327 \mathrm{~g}$, while not permanently sealed to the ring, is considered as a part of the sinker as regards mass and volume. This sinker, which is ballasted with mercury, was made in May, I908, and was annealed at $45^{\circ} \mathrm{C}$ before sealing.

The mass as determined at intervals during the progress of the work is given in Table XXI.

TABLE XXI

Determinations of Mass of Sinker No. 7

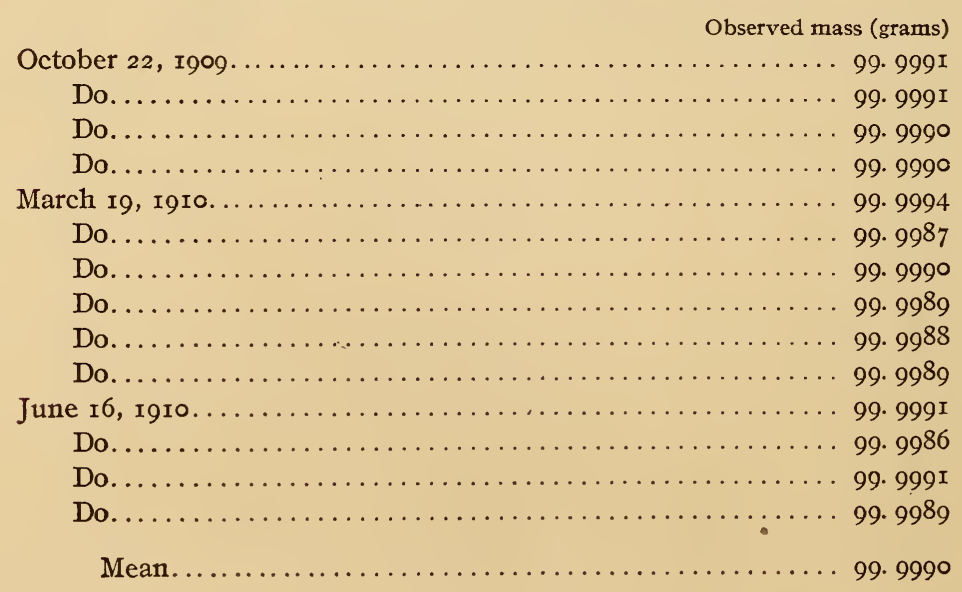


The volume of the sinker was determined by weighing in distilled water from which the air had been removed. Table XXII gives the determinations of volume made previous to the use of sinker. The results are based on the value of Chappuis ${ }^{1132}$ for the expansion of water, using $99.9990 \mathrm{~g}$ for the mass of the sinker.

\section{TABLE XXII}

Determinations of Volume and Thermal Expansion of Sinker No. 7

\begin{tabular}{|c|c|c|c|c|c|c|}
\hline \multirow{2}{*}{ Date } & \multirow{2}{*}{$\begin{array}{c}\text { Observed } \\
\text { mean tem- } \\
\text { perature }\end{array}$} & \multirow{2}{*}{$\begin{array}{c}\text { Observed } \\
\text { mean } \\
\text { volume }\end{array}$} & \multicolumn{2}{|c|}{$\begin{array}{l}\text { Reduction to integral } \\
\text { temperature }\end{array}$} & \multirow{2}{*}{$\begin{array}{c}\text { Calculated } \\
v_{\text {v }}\end{array}$} & \multirow{2}{*}{$\begin{array}{c}\text { Observa- } \\
\text { tions }\end{array}$} \\
\hline & & & $t$ & $V_{t}$ & & \\
\hline 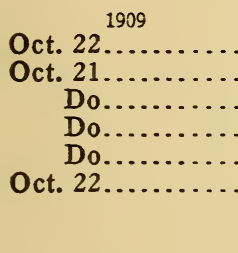 & $\begin{array}{c}3.93 \\
10.247 \\
20.136 \\
30.080 \\
39.884 \\
40.022\end{array}$ & $\begin{array}{c}\mathrm{ml} \\
\text { 47. } 6958 \\
47.7024 \\
47.7131 \\
47.7242 \\
47.7349 \\
47.7355\end{array}$ & $\begin{array}{r}4 \\
10 \\
20 \\
30 \\
40 \\
40 \\
25\end{array}$ & \begin{tabular}{|c}
$\mathrm{ml}$ \\
47.6957 \\
47.7019 \\
.47 .7128 \\
47.7239 \\
47.7348 \\
47.7353 \\
$\ldots \ldots \ldots . .$.
\end{tabular} & $\begin{array}{c}\mathrm{ml} \\
\text { 47. } 6956 \\
47.7020 \\
47.7128 \\
47.7238 \\
47.7350 \\
47.7350 \\
47.7183\end{array}$ & $\begin{array}{c}8 \\
8 \\
8 \\
8 \\
8 \\
8 \\
\text { Calcu- } \\
\text { lated }\end{array}$ \\
\hline
\end{tabular}

Equation for calculation of volume at any temperature:

$$
V_{t}=47.7172+\left[\mathrm{IroO} . \mathrm{I} \cdot(t-24)+0.9734 \cdot(t-24)^{2}\right] \times \mathrm{IO}^{-6}
$$

The volume at $25^{\circ} \mathrm{C}$ was again determined June ro, 1910, and the value found to be $47.7186 \mathrm{ml}$. For determinations of density where the absolute value is sought, as in part 3 of this work, the mean value for this period, i. e., $47.71844 \mathrm{ml}$ at $25^{\circ} \mathrm{C}$ is chosen.

\section{BALANCE, WEIGHTS, AND METHOD OF WEIGHING}

The balance used was a Rueprecht analytical balance of $200 \mathrm{~g}$ capacity, provided with special mechanism for rapid weighing and with the outside control of the weights of less than $\mathrm{I} g$. The sensibility when undamped was o.1 $6 \mathrm{mg}$ per division. The weights from $500 \mathrm{mg}$ to $10 \mathrm{mg}$ were the special weights belonging to the balance. The other weights used comprised a set of platinumplated brass weights from $200 \mathrm{~g}$ to $\mathrm{I} g$ designated as B. S. No. $5 \mathrm{I} 57$.

Previous to the experimental work the weights were carefully adjusted. A calibration made April, 1909, showed that the error of any possible combination did not exceed $+0.08 \mathrm{mg}$. 
A retest made June, I9Io, after the completion of the investigation showed the maximum error of any combination to be $+0.23 \mathrm{mg}$. This change is greater than was anticipated, yet is sufficiently small to be disregarded.

-The weighings of the sinker in the liquid were made by the method of substitution. A constant counterpoise was kept on the left pan of the balance, while the known weights were applied on the right, from which the sinker was suspended. Equilibrium was first obtained with the immersed sinker attached, then the sinker was detached and left resting on the bottom of the tube while equilibrium was again obtained with the suspending hook alone. The difference in the weights required to secure equilibrium is the apparent weight of the sinker in the liquid.

The suspension wire where it passed through the surface of the liquid was of platinum $0.3 \mathrm{~mm}$ in diameter. It was covered with a layer of dull gold by electrodeposition in order to insure wetting with the liquid, and thus avoid the sticking otherwise produced. With the wire thus prepared, weighings could be made to o.I $\mathrm{mg}$ when the sinker was not attached and to about $0.3 \mathrm{mg}$ with the sinker attached. Since the accidental error of weighing is subject to elimination in the final reduction, weighings to $0.5 \mathrm{mg}$ were accepted as being comparable with the precision in other elements of the work.

All weighings were reduced to vacuo by means of a buoyancy balance, which was devised for obtaining the buoyancy correction to weighings of water for volumetric determinations. This apparatus consists of a hollow bulb of glass having an external volume of $900 \mathrm{cc}$, suspended from one arm of a balance and counterpoised by a brass weight of equal mass. The weight of air equal in volume to the difference in volume of these two objects is indicated by the weights required on the bulb side to secure a balance. The difference in volume is $88 \mathrm{I} .3 \mathrm{cc}$; thus the buoyancy on I liter of water weighed with brass weights is obtained directly. The air density is obtained by multiplying this observed "buoyancy constant" by $\frac{\mathrm{I}}{88 \mathrm{I} \cdot 3}$. The bulb is suspended in a glass case to protect it from disturbing air currents. Correction is made for difference in temperature between this case and the balance where the 
determinations are made. The density of the weights for the purpose of correcting for displaced air is assumed to be 8.4.

\section{MATERIAL USED}

The water used in the preparation of the mixtures investigated was twice distilled, the second distillation being from alkaline potassium permanganate. The three samples of alcohol used were all prepared from sample A, previously described. The densities at ${ }_{4}^{\circ} \mathrm{C}$ and corresponding percentages of alcohol are given below:

\begin{tabular}{c|c|c}
\hline Sample & $\mathbf{D}_{4^{\circ}}^{25^{\circ}} \mathbf{C}$ & Per cent alcohol by weight \\
\hline $\mathbf{L}_{3}$ & 0.78529 & 99.93 \\
$\mathbf{3}_{\mathbf{b}}$ & .78533 & 99.91 \\
$\mathbf{I}_{3}$ & .78507 & 100.00 \\
\hline
\end{tabular}

Tests made by the chemical division of the bureau failed to show the presence of impurities other than water in sufficient amounts to affect the density appreciably, and it may be safely assumed that the effect on the thermal expansion of these last traces of impurities is less than the experimental error of the determinations.

\section{ARRANGEMENT OF EXPERIMENTAL WORK}

In order to make the final results of the determination of the thermal expansion as free as possible from the effects of progressive changes in density that are not directly attributable to changes in temperature, the observations were arranged in two series, with the order of the temperatures reversed, the temperatures of density determinations being as follows:

$\begin{array}{llllllll}\text { First series } & 10 & 15 & 20 & 25 & 30 & 35 & 40 \\ \text { Second series } & 40 & 35 & 30 & 25 & 20 & 15 & 10\end{array}$

In each series the observations were distributed at approximately equal time intervals. Each series required a day for completion.

By employing this isochronously symmetrical arrangement of observations and by taking the mean of the two series disturbing causes which are linear functions of time are practically eliminated. 
The principal disturbing causes which were anticipated were evaporation of alcohol and absorption of air and moisture.

Notwithstanding the precautions for the exclusion of atmos= pheric moisture and prevention of evaporation from the densimeter tube when not actually observing, the change in concentration due to these causes was found to be appreciable in most of the mixtures. Owing to the lowerr vapor pressure of alcohol the vapor usually is of higher concentration than the mixture which yields it, and thus a progressive dilution of the mixture is produced in most cases. That this dilution is uniformly distributed throughout the mixture is unlikely. There is besides, with some of the mixtures, condensation of the vapor in the top of the tube and on the suspension, which tends to run back into the upper layers of the liquid. This may account for the fact that in the 90 per cent mixture there appeared to be between the series an increase in concentration. The increase in the concentration of the ro per cent mixture, however, was artificial, being caused by the intentional addition of alcohol to compensate for evaporation.

It was found that unless dissolved air was extracted from the mixtures there was danger of air being expelled from the liquid at the higher temperatures and attaching to the sinker as bubbles, preventing a successful series of observations. Hence, before the determination for any mixture, and in some cases between the two series of observations, the mixture was evacuated to low pressure to remove a sufficient amount of the dissolved air to prevent this difficulty. During the series air was doubtless reabsorbed and at an unknown rate, but determinations made elsewhere of the effect of dissolved air on the density of various mixtures at $25^{\circ} \mathrm{C}$ showed the total effect at that temperature to be so small that any large variable effect at the temperatures employed and in the time allowed would be improbable.

Examination of the experimental results shows that the alteration in concentration of the mixtures was usually less for the higher than for the lower per cents of alcohol. It is also seen that between the first and second series of observations on several of the mixtures a considerable change occurred. This can be attributed to the evacuation of the mixture previous to the second series to remove air by which alcohol vapor was also removed. 
The manner of observing was as follows: With the liquid to be investigated in the tube, the sinker immersed, the cap on and closed by the suspension plug, and the tube in place in the control bath, the temperature was brought to the initial temperature of the series. The brine flow, the by-pass in the circulating apparatus, the thermoregulator, and the electric energy supply were successively adjusted to maintain the desired constant temperature. Sufficient time was allowed for the inner bath to acquire a constant or very slowly rising temperature. The sinker was then suspended from the balance and weighed. The thermometers were both read. The sinker was detached and the suspension weighed. The sinker was again suspended and weighed and the thermometers again read. At the conclusion of this set of observations the top of the densimeter tube was closed by the suspension plug and the temperature changed to the next one of the series as rapidly as the capacity of the heating coil or of the cooling coil would permit. While this temperature change was taking place the ice points of the thermometers were read and the buoyancy constant observed. The temperature control was readjusted for constant regulation at the new temperature and observations for density and temperature were again made. This procedure was repeated until the series was complete.

\section{EXPERIMENTAL RESULTS}

\section{CALCULATION OF RESULTS}

The total correction to the thermometer at the temperature of the determination was obtained by use of the observed ice points and the calibration corrections. Each observed temperature was corrected and the mean of the set of four taken as the temperature of the determination.

The apparent weight of the sinker in the liquid is given by the difference between the balance readings with sinker on and with sinker off. The mean of the two values of the apparent weight of sinker thus obtained is corrected by subtracting the weight of air displaced by the weights. To obtain this correction the volume of the weights (assuming their density to be 8.4) is multiplied by the observed air density. The application of this correction gives the true weight of the sinker in the liquid. The difference between 


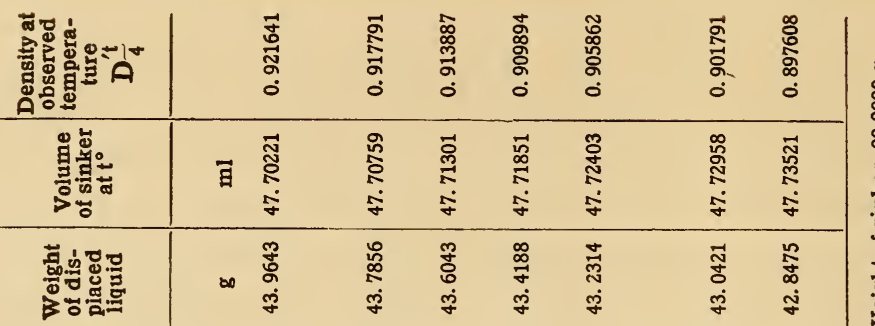

\begin{tabular}{|c|c|c|c|c|c|c|c|}
\hline 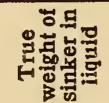 & 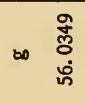 & 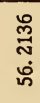 & $\begin{array}{l}\text { gे } \\
\text { बे } \\
\text { i }\end{array}$ & $\begin{array}{l}\text { 若 } \\
\text { i } \\
\text { i }\end{array}$ & $\begin{array}{l}\infty \\
0 \\
0 \\
i \\
i\end{array}$ & $\begin{array}{l}\text { 중 } \\
\text { ò } \\
\text { in }\end{array}$ & $\stackrel{\overrightarrow{\text { ते }}}{\text { in }}$ \\
\hline
\end{tabular}

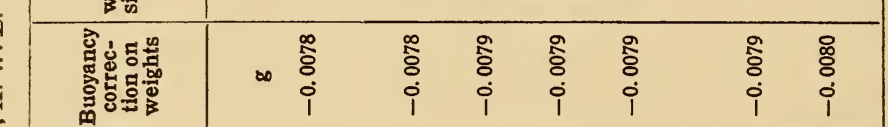

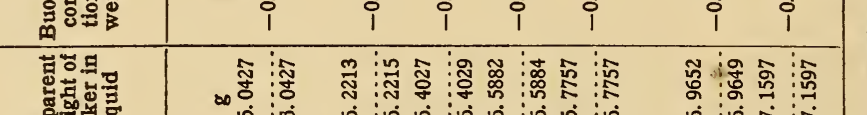

19.

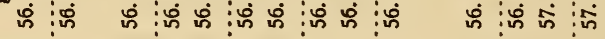

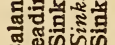
ฮอิอ

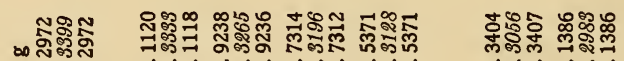

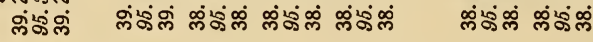

\begin{tabular}{|c|c|c|c|c|c|c|c|}
\hline 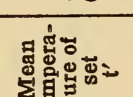 & $\begin{array}{l}9 \\
0 \\
0\end{array}$ & $\bar{\sigma}$ & 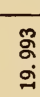 & 。 & 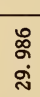 & \%̊ & \% \\
\hline
\end{tabular}

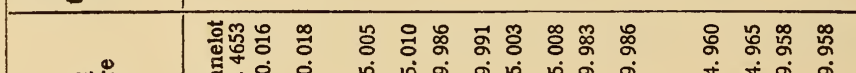

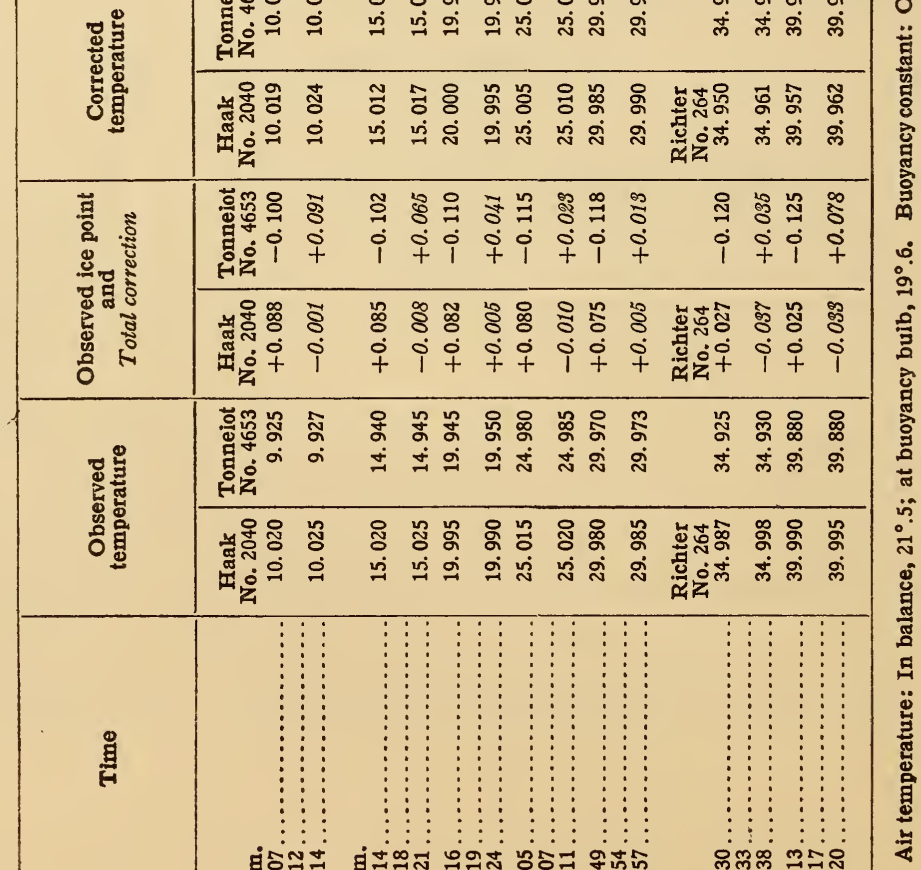




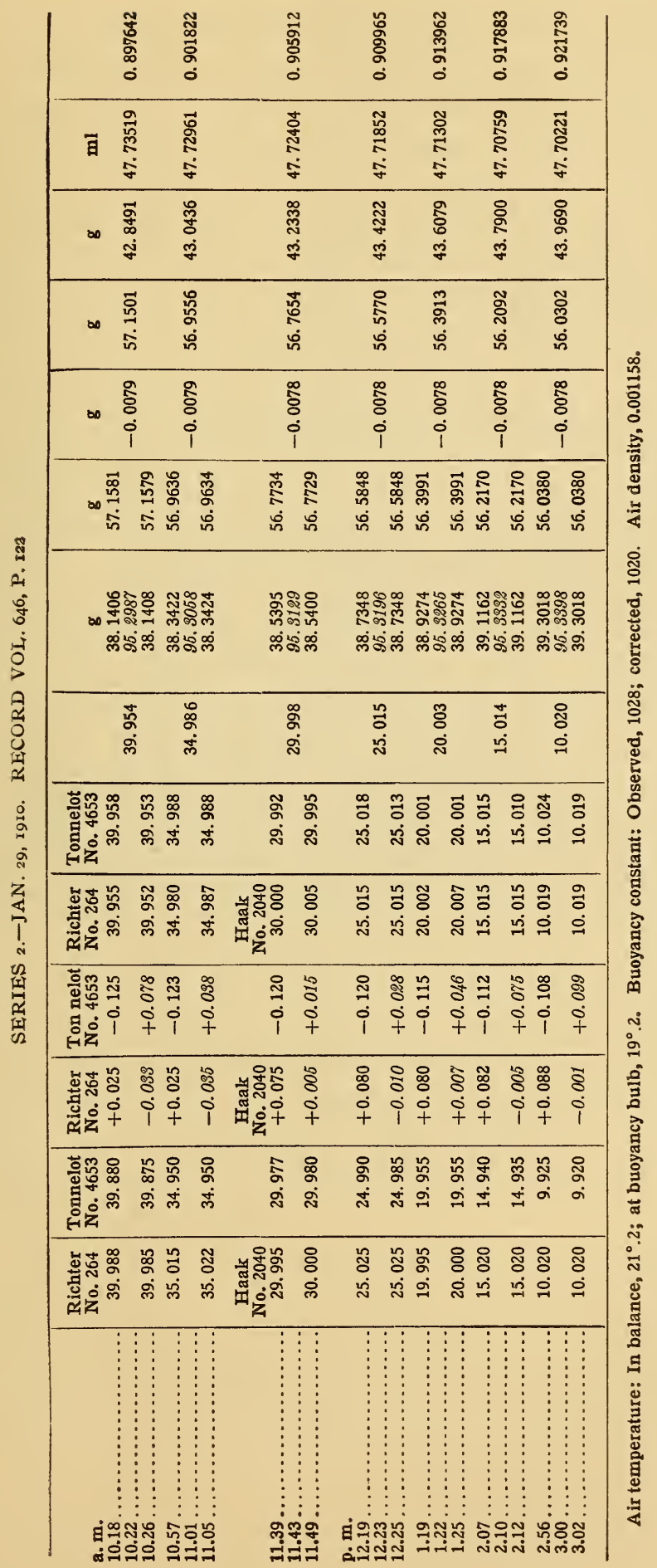


the weight of the sinker in the liquid and its weight in vacuo gives the weight of the liquid displaced by the sinker. This weight divided by the volume of the sinker at the temperature of the determination gives the density of the liquid at that temperature in grams per milliliter.

The calculation of the density of the liquid as described above may be expressed by the following equation:

$$
\mathrm{D}_{\frac{\mathrm{t}}{4}}=\frac{S-\frac{W_{1}-w+W_{2}-w}{2}\left(1-\frac{\rho}{8.4}\right)}{\mathrm{V}_{t}}
$$

Where $D_{t}=$ density of sample at temperature $t$

$\overline{4}$

$S=$ mass of sinker

$V_{\mathrm{t}}=$ volume of sinker at the temperature $t$

$t=$ temperature of determination

$W_{1}, W_{2}=$ balance readings with sinker on

$w=$ balance readings with sinker off

$\rho=$ air density

\section{COPY OF ORIGINAL DATA}

A copy of the record showing the observations comprising the two series of determinations for a single mixture is given in Table XXIII (pp. 382-383). This table illustrates the arrangement of the experimental work and also the calculation of results as described above. 


\section{REDUCTION AND ADJUSTMENT OF RESULTS}

From the observations and calculations as described and illustrated above are obtained the experimental results given in Tables XXIV to XXXV, comprising for each mixture a double series of density determinations together with the corresponding temperatures. These temperatures are all very close to the integral temperatures intended. For the purpose of simplifying the adjustment of results the determined densities are reduced to the values corresponding to the integral temperatures. Comparison between the densities thus reduced shows the permanent change occurring in the liquid during the progress of the determination not directly attributable to the change in temperature. This permanent change which is caused by the evaporation of alcohol and by the abosrption of moisture may be regarded as a linear function of the position of the determination in the series, since the different groups of observations in a series occupy approximately the same time and are separated by equal intervals of time. The total permanent change occurring between any determination of the first series and the corresponding one of the second is represented by the equation:

$$
\Delta=a+b(7-n)
$$

where $n$ is the number of the determination in the first series, $a$ is the change occurring between the first and second series-that is, between the seventh and eighth determinations-and may include changes from any intentional or accidental cause, $b$ depends on the rate of change during the progress of a single series and is assumed to be the same in the two series. By a least square adjustment of the observed apparent permanent change in density between the series, the constants $a$ and $b$ are determined. The adjusted value of $\Delta$ is then calculated by these coefficients, and each determined density corrected by one-half the corresponding adjusted $\Delta$ with the appropriate sign.

It is evident that the final value of the density at each temperature will be the same whether the mean be taken of the two determinations at that temperature or whether these determinations be first adjusted, as indicated above, to correct for the progressive change of density due to evaporation of alcohol and 
absorption of water vapor. This adjustment, however, is desirable in order that a check may be had upon the agreement of the two determinations when all explainable differences have been taken into account. This agreement is an indication of the magnitude of the accidental errors of the individual determinations.

The observed densities thus adjusted to values corresponding to the mean concentration of the mixture are further adjusted on the assumption that the equation

$$
D \frac{t}{4}=D^{25}+\alpha(t-25)+\beta(t-25)^{2}+\gamma(t-25)^{3}
$$

represents the change in density depending on the change in temperature alone. By the method of least squares, $D \frac{25}{4}, \alpha, \beta, \gamma$ are determined. The adjusted value of $D \frac{t}{4}$ is then calculated. In the values of observed $D_{\frac{1}{4}}^{t}$ minus calculated $D \frac{t}{4}$ will be combined the accidental experimental errors as well as errors due to the assumed form of functions in the least square adjustments of the observations. It appears from examination of these residuals that the assumptions made are in accordance with the experimental data, unless these errors are systematically compensated, as the residuals are seen to be within the limits of accidental error. 


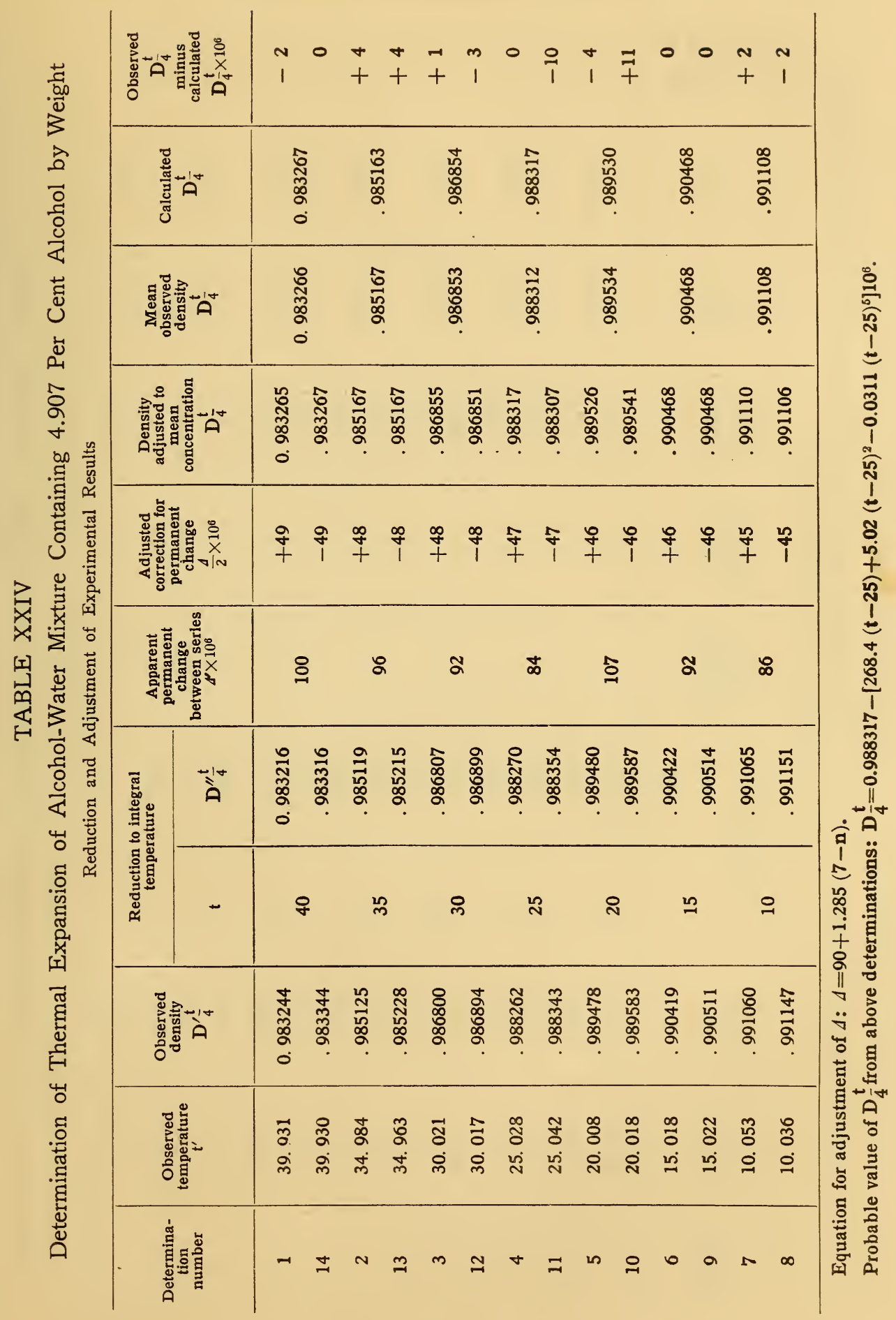




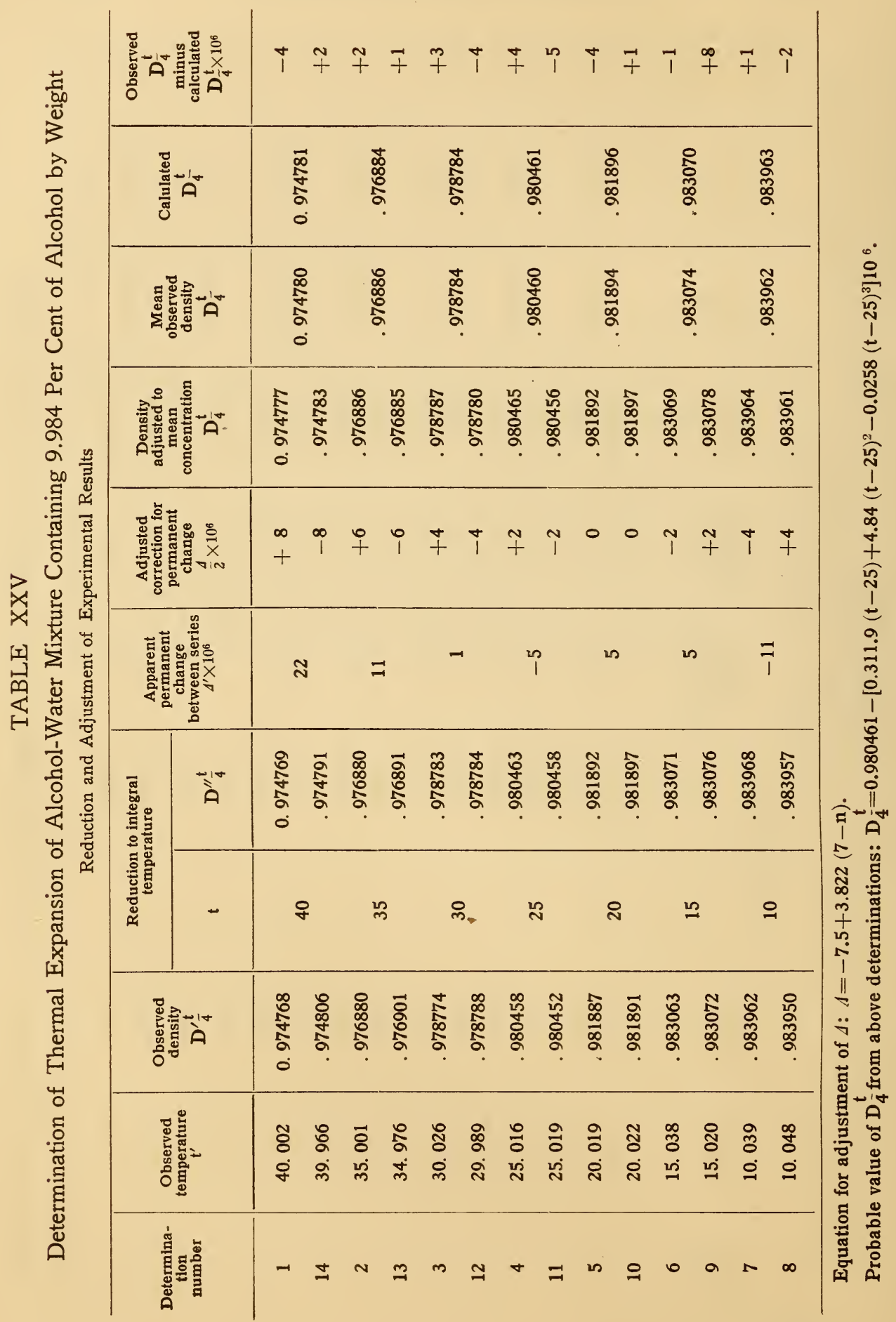




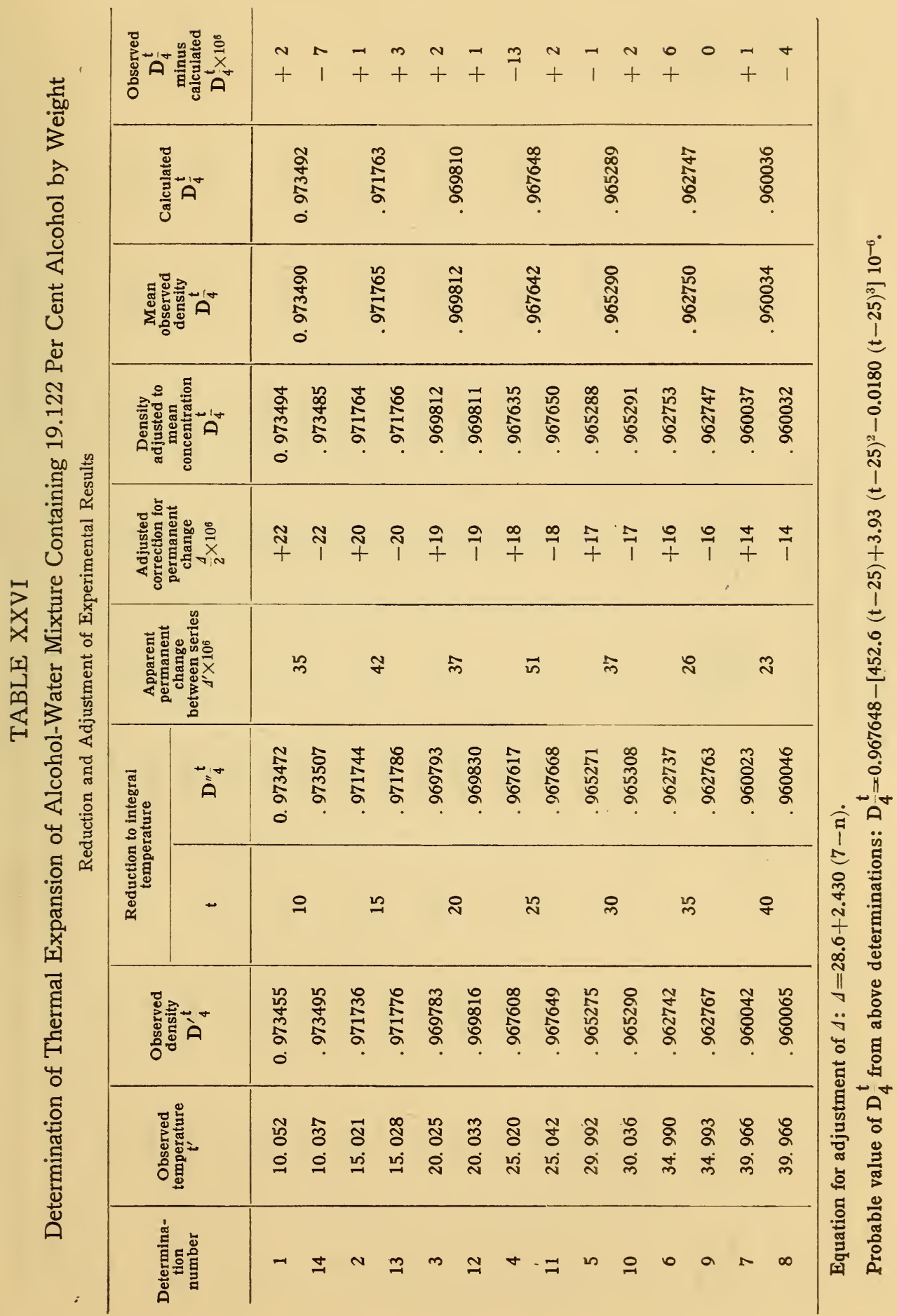




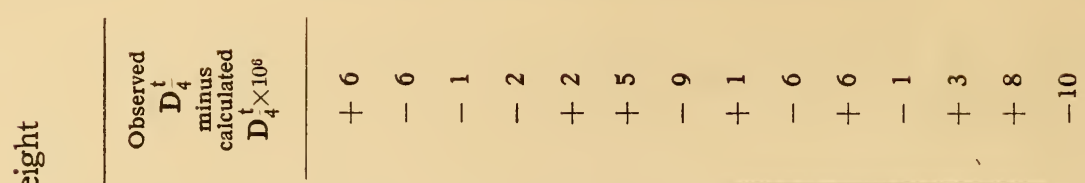

\begin{tabular}{|c|c|c|c|c|c|c|}
\hline 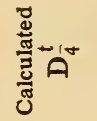 & $\begin{array}{l}8 \\
8 \\
8 \\
0\end{array}$ & $\begin{array}{l}0 \\
\text { م } \\
\text { مे }\end{array}$ & $\begin{array}{l}\text { 여 } \\
\text { 혀 }\end{array}$ & 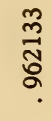 & 0 & \\
\hline
\end{tabular}

㟧

$\stackrel{\infty}{a}$

สิ

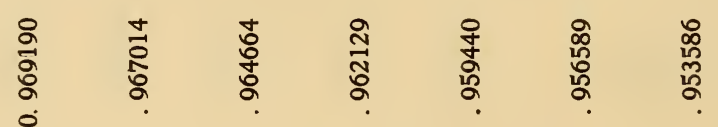

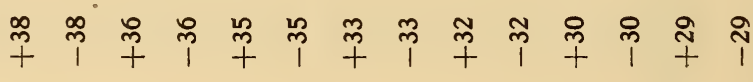

\begin{tabular}{|c|c|c|c|c|c|c|c|c|c|c|c|c|c|c|c|}
\hline 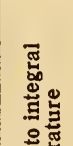 & Aे & $\begin{array}{l}\stackrel{\infty}{\circ} \\
\stackrel{\circ}{\circ} \\
0 \\
0\end{array}$ & $\begin{array}{l}\text { స్ } \\
\text { ठั }\end{array}$ & $\begin{array}{l}\text { ᄋे } \\
\text { ò } \\
\text { \&̊ }\end{array}$ & $\begin{array}{l}\text { ஜ̊ } \\
\text { ధ̊ㅇ }\end{array}$ & 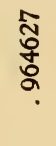 & $\begin{array}{l}8 \\
\text { ¿ } \\
\text { षे }\end{array}$ & $\begin{array}{l}\text { ठ․ㅀㅇ } \\
\text { ه }\end{array}$ & 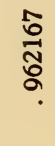 & 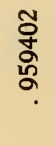 & 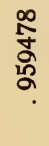 & 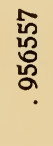 & $\begin{array}{l}\text { त్ } \\
\text { นू }\end{array}$ & 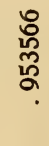 & $\begin{array}{l}\text { ષ্ } \\
\text { นू }\end{array}$ \\
\hline
\end{tabular}

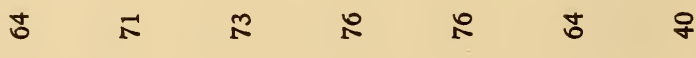

羟

तี

हृ

낭

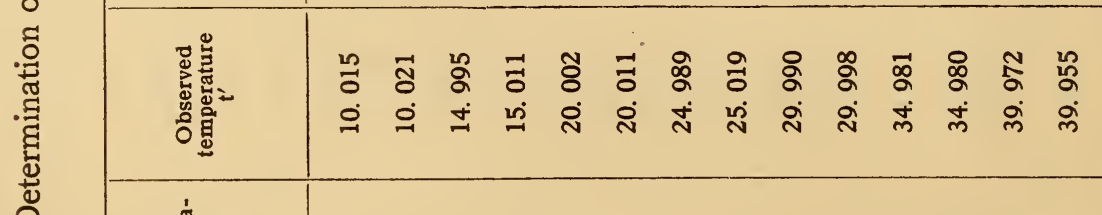

은 유 유 융

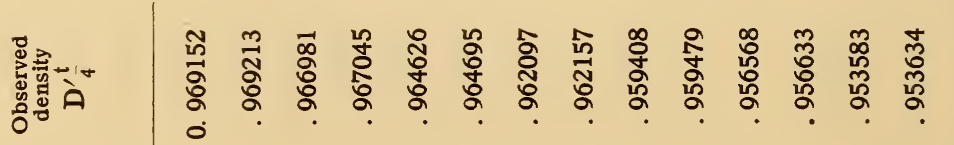

9. 


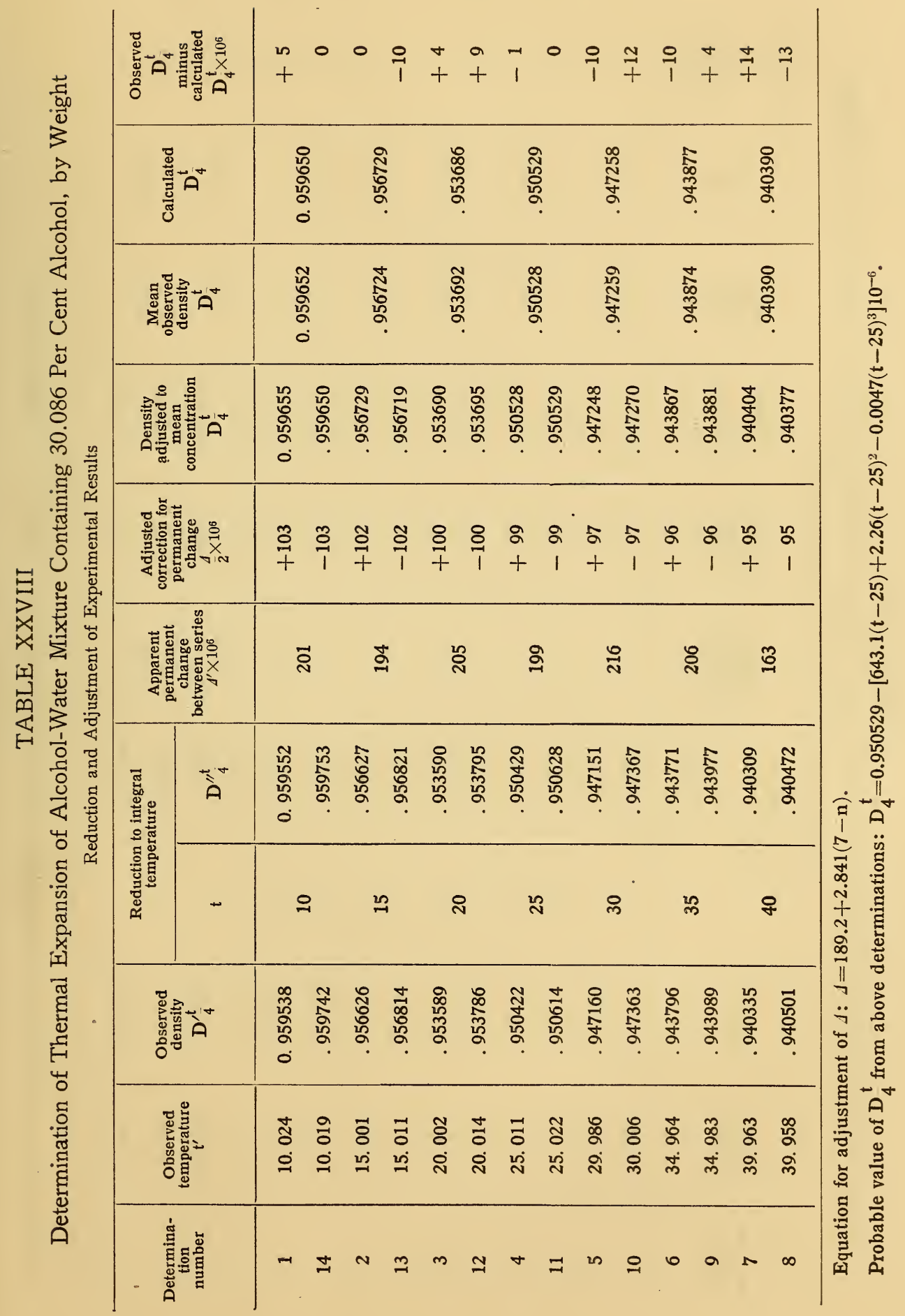




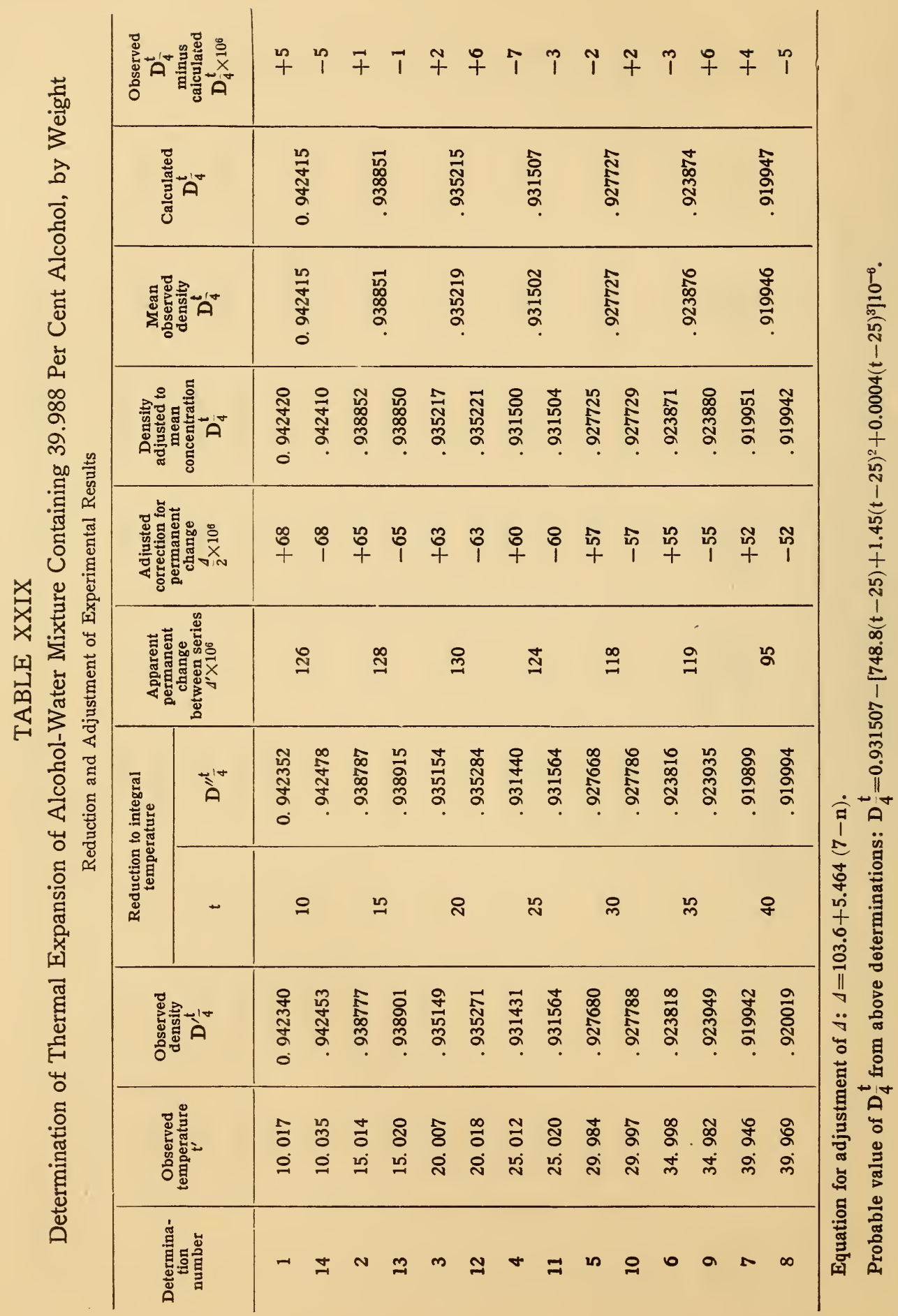


Osborne] Density and Expansion of Alcohol

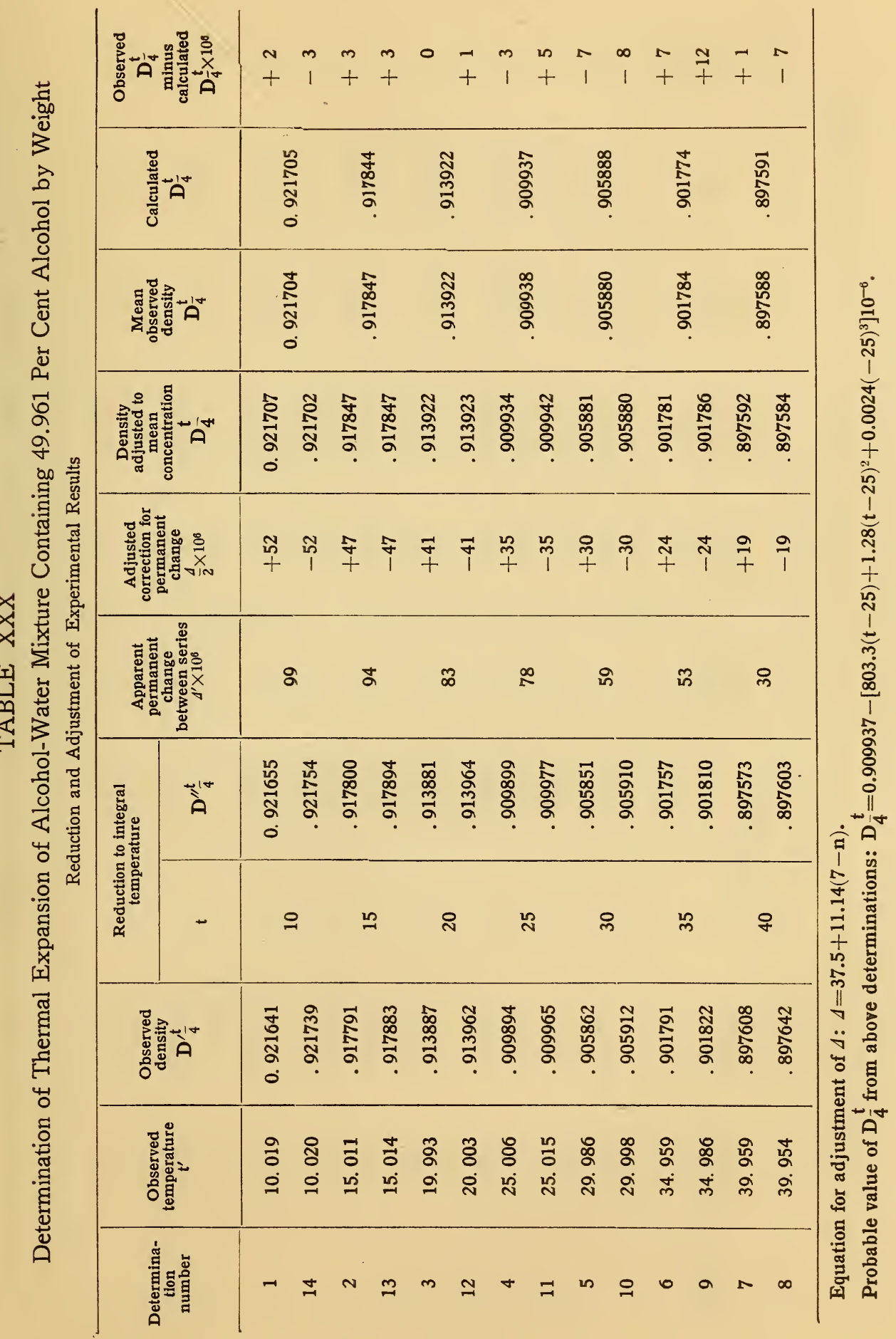




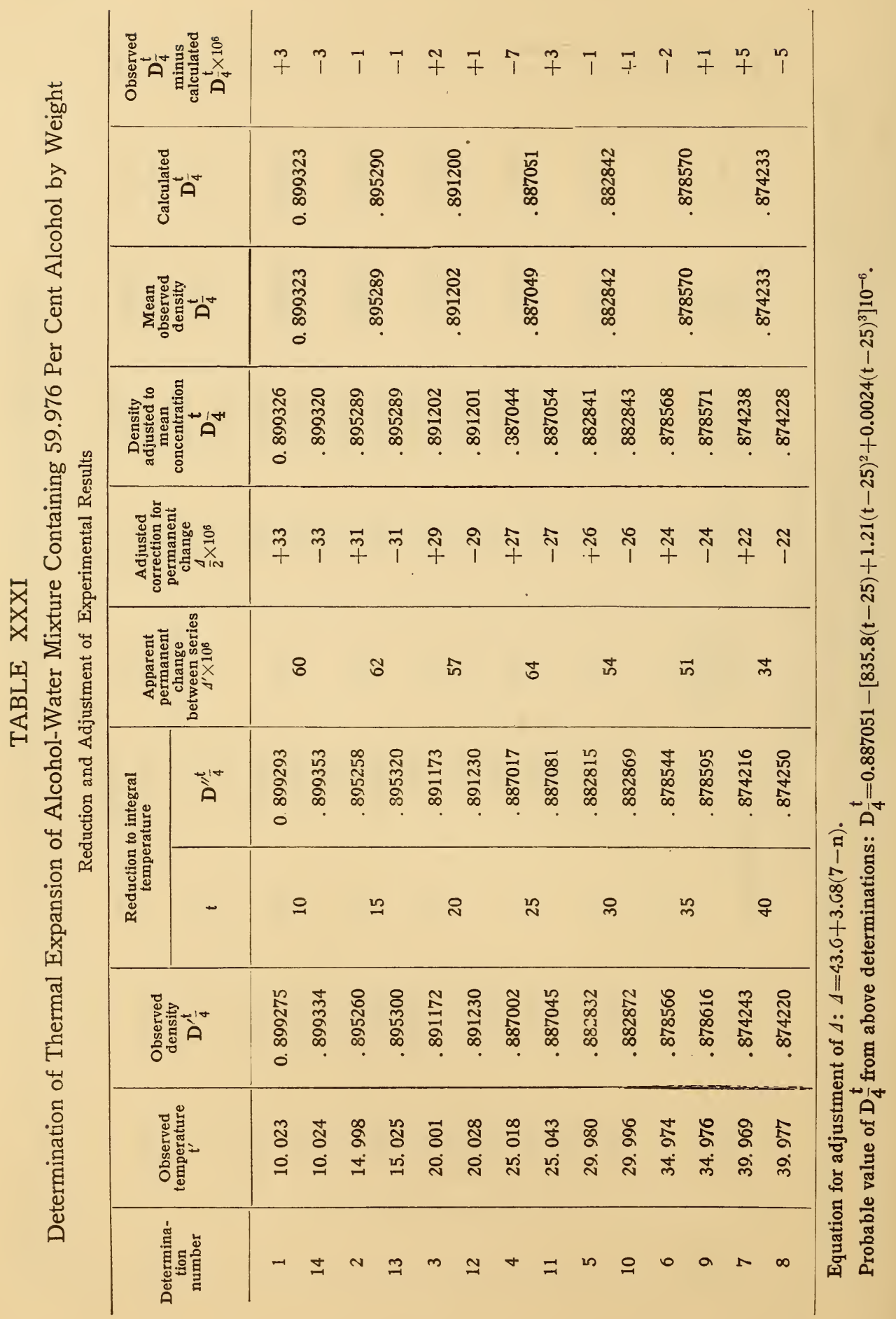




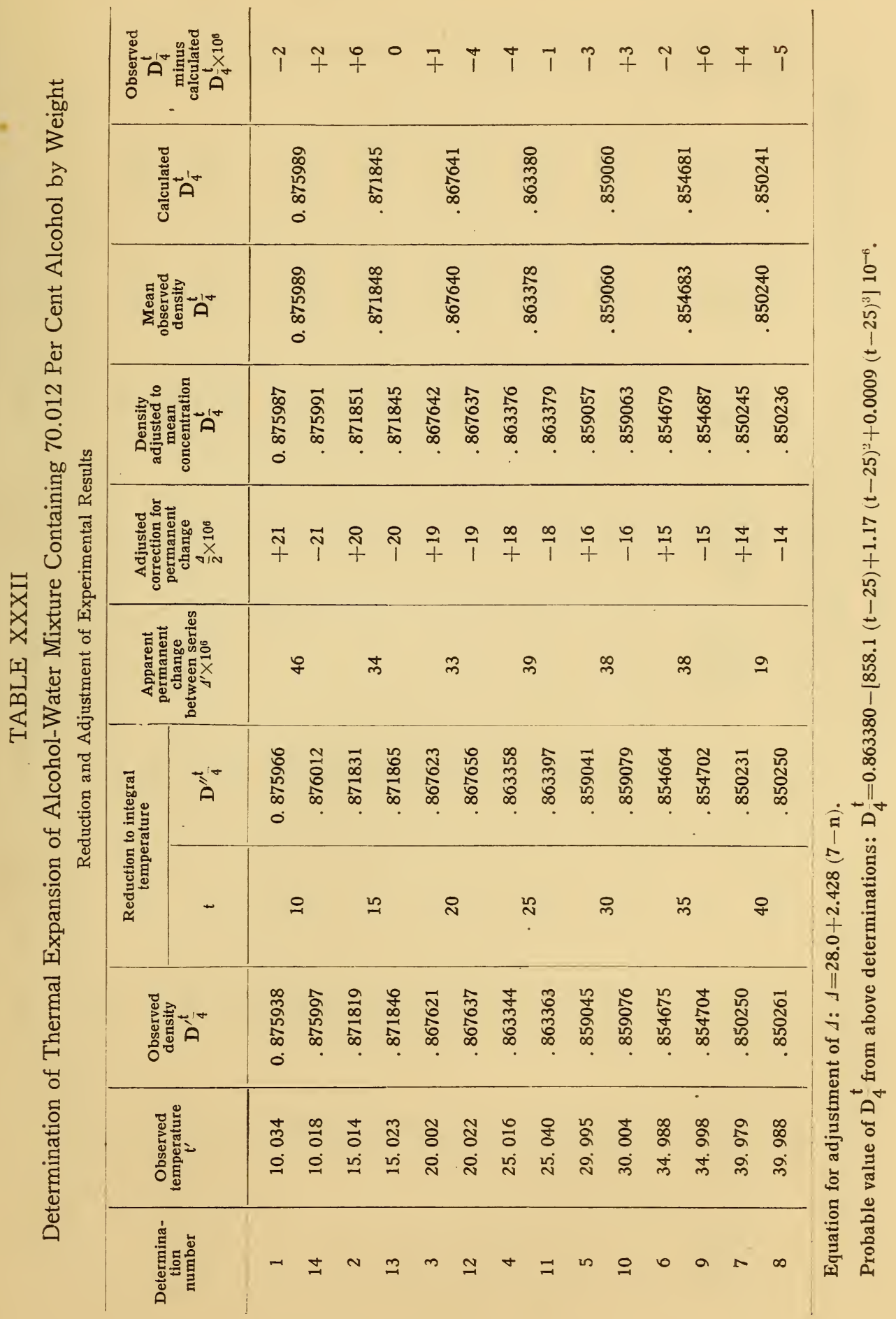




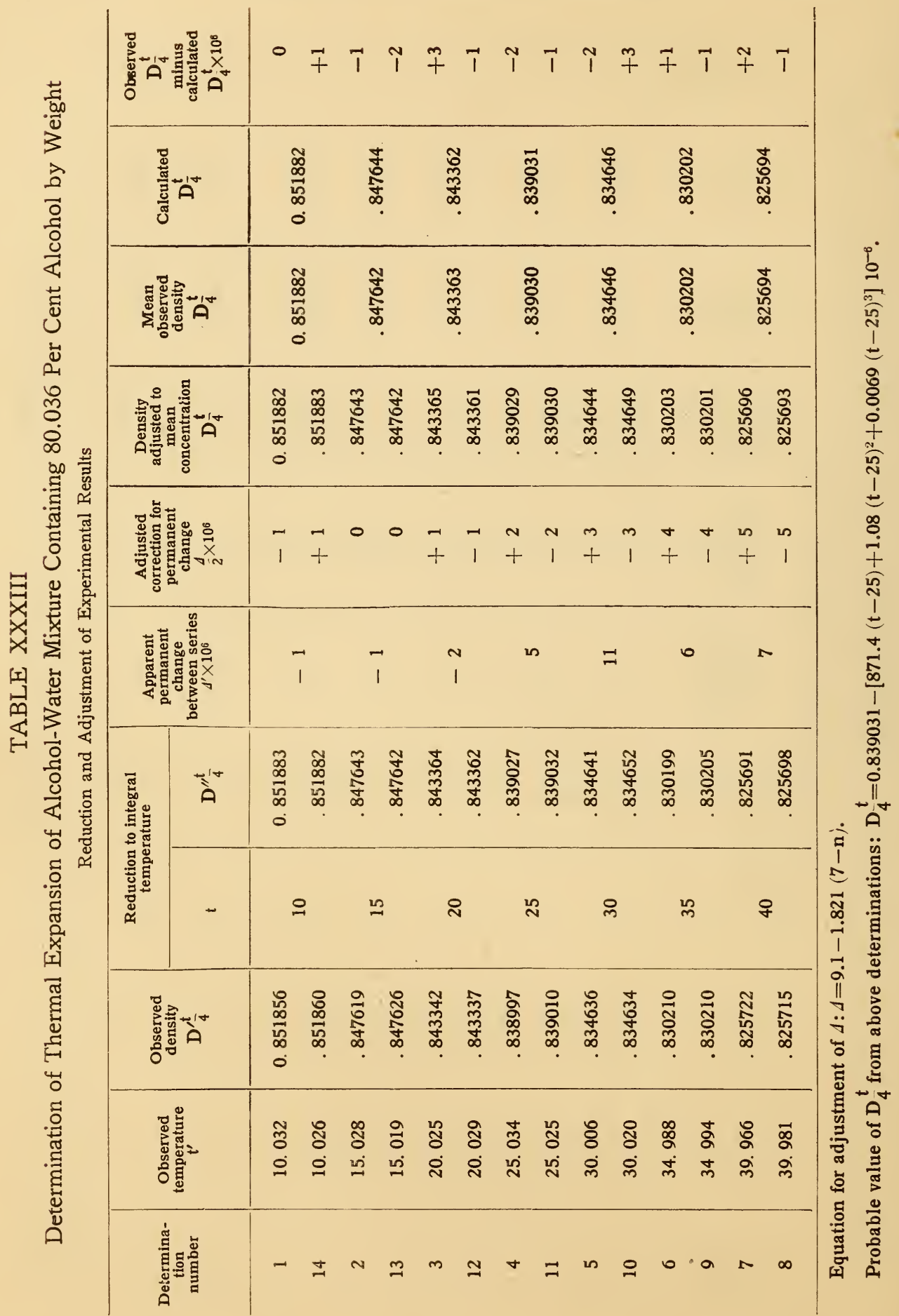




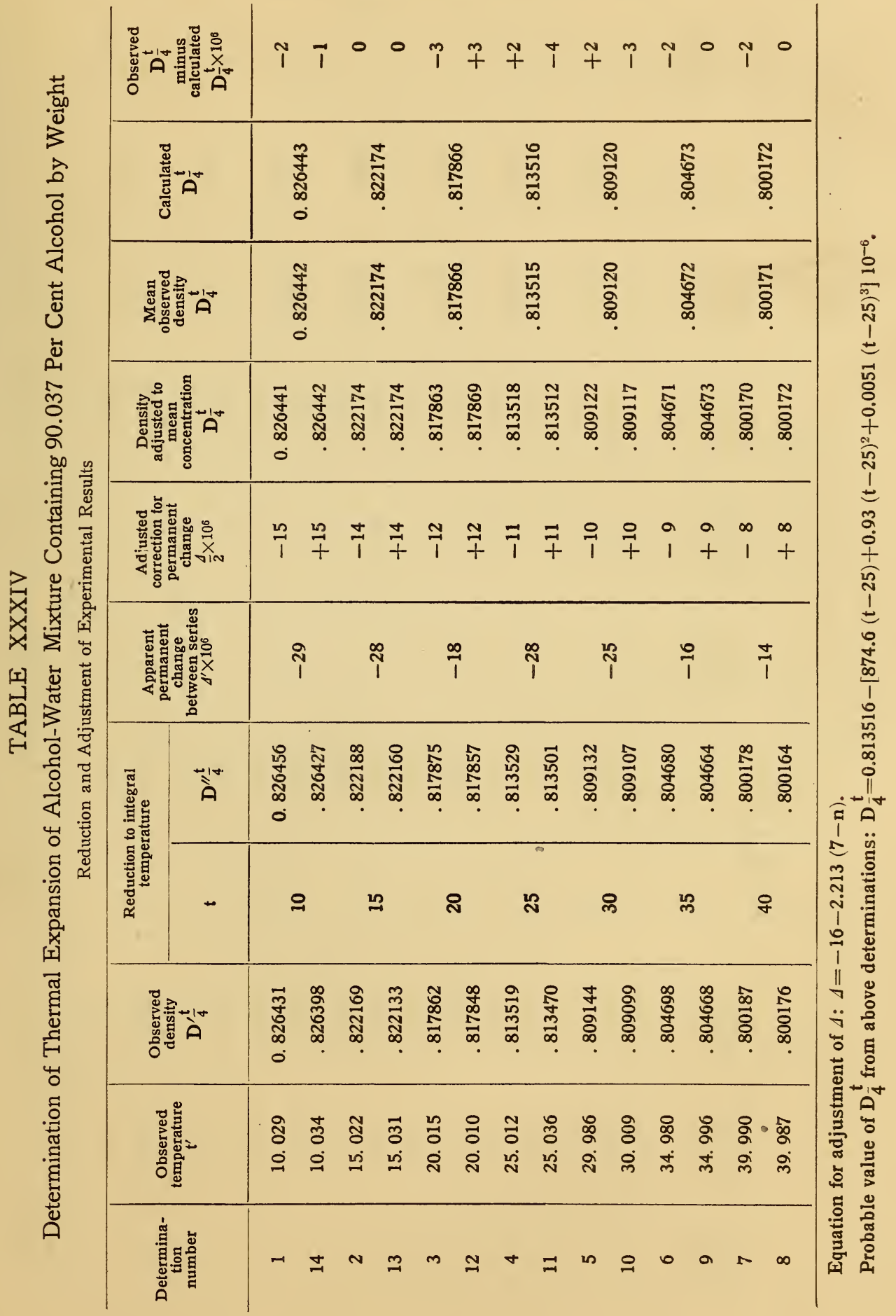




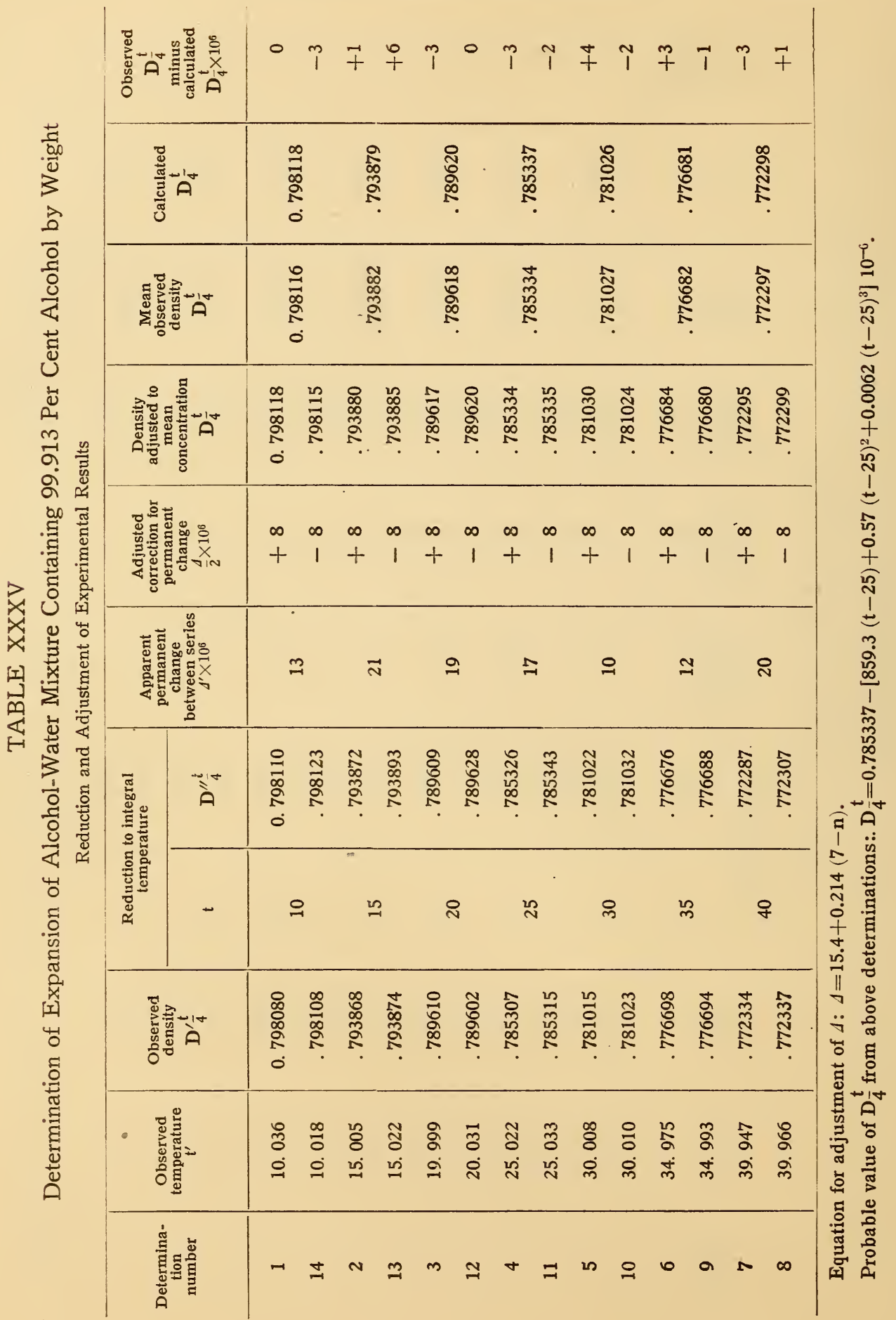




\section{RÉSUMÉ OF RESULTS}

By reduction and adjustment of experimental results there is derived for each mixture of alcohol and water investigated an equation for thermal expansion of the form:

$$
D_{\frac{1}{4}}^{t}=D_{\frac{25}{4}}+\alpha(t-25)+\beta(t-25)^{2}+\gamma(t-25)^{3}
$$

$D^{25}$ and the coefficients $\alpha, \beta, \gamma$, having been determined from the experimental data.

The constant $D \frac{25}{4}$ for each mixture represents the mean density at $25^{\circ}$ in terms of the density of water at $4^{\circ}$ as the unit and is used for obtaining the mean concentration of the mixture used. A table showing the relation between density at $25^{\circ}$ and concentration is given on page 424 .

The assembled results of the experimental work on thermal expansion of alcohol-water mixtures are given in Table XXXVI. Included in this table are the corresponding coefficients for water calculated from the experimental work of Chappuis ${ }^{1132}$ using the densities at $10,15,20,25,30,35,40^{\circ} \mathrm{C}$, upon which the present work is based. The coefficients $\alpha, \beta, \gamma$, are shown graphically as functions of the per cent of alcohol in Fig. 9.

Interpolated values of $\alpha, \beta, \gamma$ obtained by the graphical method are given for each integral per cent of alcohol in Table XXXVII $a$. The interpolation is carried to the number of figures shown for the purpose of avoiding arithmetic errors in the calculation of the final density Table XLIX in part 3. They should not be assumed correct to the last figure given. Furthermore, they can not be assumed as true except for the range of temperature used in their determination-viz, $10^{\circ} \mathrm{C}$ to $40^{\circ} \mathrm{C}$.

In Table XXXVII $b$ are given the coefficients $A, B, C$ in the equation for thermal expansion of the form:

$$
V_{t}=V_{25}\left[\mathrm{r}+A(t-25)+B(t-25)^{2}+C(t-25)^{3}\right]
$$

these coefficients having been calculated for each integral per cent of alcohol from the corresponding coefficients $\alpha, \beta, \gamma$, given in Table XXXVII $a$. 


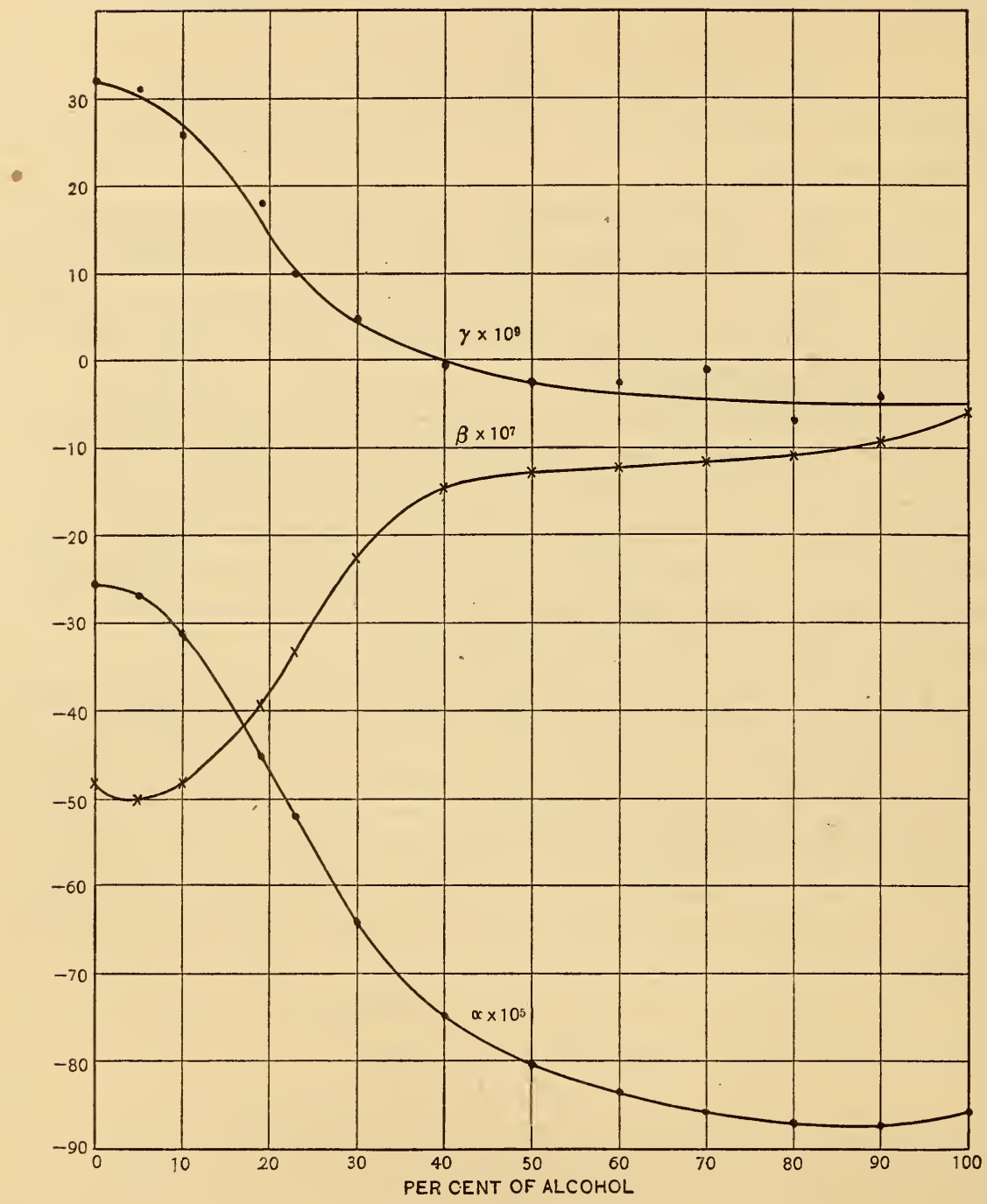

Fig. 9.-Coefficients $\alpha, \beta, \gamma$ 
TABLE XXXVI

Thermal Expansion of Alcohol-Water Mixtures. Assembled Experimental Results

Equation: $D \frac{1}{4}=D \frac{25}{4}+\alpha(\mathrm{t}-25)+\beta(\mathrm{t}-25)^{2}+\gamma(\mathrm{t}-25)^{3}$. Temperature range: $10^{\circ} \mathrm{C}$ to $40^{\circ} \mathrm{C}$

\begin{tabular}{c|c|c|c|c}
\hline $\begin{array}{c}\text { Per cent alcohol } \\
\text { by weight }\end{array}$ & $\mathrm{D}_{\frac{25}{4}}^{25}$ & $a \times 10^{7}$ & $\beta \times 10^{8}$ & $\gamma \times 10^{10}$ \\
\hline
\end{tabular}

RESULTS FOR WATER ACCORDING TO CHAPPUIS'S DATA

\begin{tabular}{l|l|l|l|l}
\hline 0 & 0.997077 & -2565 & -484 & +319 \\
\hline
\end{tabular}

RESULTS OF PRESENT INVESTIGATION

\begin{tabular}{r|r|r|r|r}
\hline 4.907 & 0.988317 & -2684 & -502 & +311 \\
9.984 & .980461 & -3119 & -484 & +258 \\
19.122 & .967648 & -4526 & -393 & +180 \\
22.918 & .962133 & -5224 & -331 & +100 \\
30.086 & .950529 & -6431 & -226 & +47 \\
39.988 & .931507 & -7488 & -145 & -4 \\
49.961 & .909937 & -8033 & -128 & -24 \\
59.976 & .887051 & -8358 & -121 & -24 \\
70.012 & .863380 & -8581 & -117 & -9 \\
80.036 & .839031 & -8714 & -108 & -69 \\
90.037 & .813516 & -8746 & -93 & -51 \\
99.913 & .785337 & -8593 & -57 & -62 \\
\hline
\end{tabular}


TABLE XXXVIIa.--Interpolated values of $\alpha, \beta, \gamma$, between $10^{\circ} \mathrm{C}$ to $40 \mathrm{C}^{\circ}$. in the equation:

$$
\mathrm{D}_{4}^{\mathrm{t}}=\mathrm{D}_{\frac{25}{4}}+\alpha(\mathrm{t}-25)+\beta(\mathrm{t}-25)^{2}+\gamma(\mathrm{t}-25)^{3}
$$

\begin{tabular}{|c|c|c|c|c|c|c|c|}
\hline $\begin{array}{l}\text { Per cent } \\
\text { alcohol } \\
\text { by weight }\end{array}$ & $a \times 10^{7}$ & $\beta \times 10^{8}$ & $\gamma \times 10^{9}$ & $\begin{array}{l}\text { Per cent } \\
\text { alcohol } \\
\text { by weight }\end{array}$ & $a \times 10^{7}$ & $\beta \times 10^{8}$ & $\gamma \times 10^{9}$ \\
\hline $\begin{array}{r}0 \\
1 \\
2 \\
3 \\
4 \\
5 \\
6 \\
7 \\
8 \\
9 \\
10 \\
11 \\
12 \\
13 \\
14 \\
15 \\
16 \\
17 \\
18 \\
19 \\
20 \\
21 \\
22 \\
23 \\
24 \\
25 \\
26 \\
27 \\
28 \\
-29 \\
30 \\
31 \\
32 \\
33 \\
34 \\
35 \\
36 \\
37 \\
38 \\
39 \\
40 \\
41 \\
42 \\
43 \\
44 \\
45 \\
46 \\
47 \\
48 \\
49 \\
50\end{array}$ & $\begin{array}{l}-2565 \\
-2574 \\
-2591 \\
-2613 \\
-2646 \\
-2689 \\
-2745 \\
-2816 \\
-2901 \\
-3003 \\
-3121 \\
-3244 \\
-3374 \\
-3513 \\
-3662 \\
-3817 \\
-3978 \\
-4146 \\
-4322 \\
-4504 \\
-4686 \\
-4870 \\
-5055 \\
-5239 \\
-5419 \\
-5601 \\
-5778 \\
-5951 \\
-6114 \\
-6271 \\
-6419 \\
-6554 \\
-6685 \\
-6810 \\
-6929 \\
-7040 \\
-7144 \\
-7239 \\
-7330 \\
-7413 \\
-7489 \\
-7561 \\
-7627 \\
-7689 \\
-7748 \\
-7802 \\
-7855 \\
-7903 \\
-7950 \\
-7993 \\
-8035\end{array}$ & $\begin{array}{l}-484 \\
-490 \\
-496 \\
-499 \\
-501 \\
-502 \\
-501 \\
-498 \\
-495 \\
-490 \\
-484 \\
-476 \\
-469 \\
-460 \\
-452 \\
-442 \\
-432 \\
-420 \\
-408 \\
-395 \\
-380 \\
-363 \\
-346 \\
-329 \\
-313 \\
-298 \\
-282 \\
-268 \\
-253 \\
-240 \\
-227 \\
-215 \\
-204 \\
-194 \\
-185 \\
-176 \\
-168 \\
-161 \\
-155 \\
-150 \\
-145 \\
-141 \\
-138 \\
-136 \\
-134 \\
-133 \\
-132 \\
-131 \\
-130 \\
-129 \\
-128\end{array}$ & 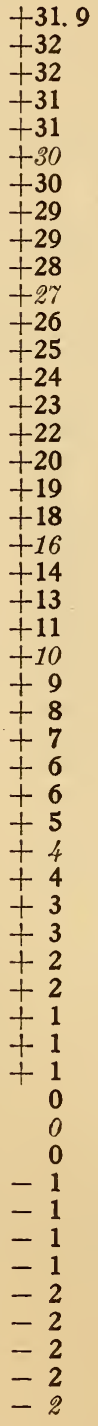 & $\begin{array}{l}50 \\
51 \\
52 \\
53 \\
54 \\
55 \\
56 \\
57 \\
58 \\
59 \\
60 \\
61 \\
62 \\
63 \\
64 \\
65 \\
66 \\
67 \\
68 \\
69 \\
70 \\
71 \\
72 \\
73 \\
74 \\
75 \\
76 \\
77 \\
78 \\
79 \\
80 \\
81 \\
82 \\
83 \\
84 \\
85 \\
86 \\
87 \\
88 \\
89 \\
90 \\
91 \\
92 \\
93 \\
94 \\
95 \\
96 \\
97 \\
98 \\
99 \\
100\end{array}$ & $\begin{array}{l}-8035 \\
-8074 \\
-8111 \\
-8147 \\
-8181 \\
-8212 \\
-8244 \\
-8274 \\
-8302 \\
-8330 \\
-8359 \\
-8384 \\
-8410 \\
-8435 \\
-8459 \\
-8482 \\
-8503 \\
-8524 \\
-8544 \\
-8564 \\
-8581 \\
-8599 \\
-8614 \\
-8629 \\
-8643 \\
-8657 \\
-8669 \\
-8681 \\
-8692 \\
-8703 \\
-8714 \\
-8723 \\
-8731 \\
-8739 \\
-8745 \\
-8751 \\
-8753 \\
-8754 \\
-8753 \\
-8751 \\
-8746 \\
-8738 \\
-8728 \\
-8715 \\
-8700 \\
-8685 \\
-8668 \\
-8650 \\
-8632 \\
-8613 \\
-8591\end{array}$ & $\begin{array}{l}-128 \\
-127 \\
-126 \\
-126 \\
-125 \\
-124 \\
-124 \\
-123 \\
-122 \\
-122 \\
-121 \\
-121 \\
-120 \\
-120 \\
-120 \\
-119 \\
-119 \\
-119 \\
-118 \\
-117 \\
-117 \\
-116 \\
-116 \\
-115 \\
-114 \\
-113 \\
-112 \\
-111 \\
-110 \\
-109 \\
-108 \\
-107 \\
-106 \\
-105 \\
-104 \\
-102 \\
-101 \\
-99 \\
-97 \\
-95 \\
-93 \\
-90 \\
-88 \\
-84 \\
-81 \\
-78 \\
-74 \\
-70 \\
-66 \\
-61 \\
-56\end{array}$ & $\begin{array}{l}-2 \\
-3 \\
-3 \\
-3 \\
-3 \\
-3 \\
-3 \\
-4 \\
-4 \\
-4 \\
-4 \\
-4 \\
-4 \\
-4 \\
-4 \\
-4 \\
-4 \\
-4 \\
-4 \\
-4 \\
-5 \\
-5 \\
-5 \\
-5 \\
-5 \\
-5 \\
-5 \\
-5 \\
-5 \\
-5 \\
-5 \\
-5 \\
-5 \\
-5 \\
-5 \\
-5 \\
-5 \\
-5 \\
-5 \\
-5 \\
-5 \\
-5 \\
-5 \\
-5 \\
-5 \\
-5 \\
-5 \\
-5 \\
-5 \\
-5 \\
-5\end{array}$ \\
\hline
\end{tabular}


TABLE XXXVIIb.-Values of A, B, C, between $10^{\circ} \mathrm{C}$ to $40^{\circ} \mathrm{C}$, in the equation :

$$
\mathrm{V}_{\mathrm{t}}=\mathrm{V}_{25}\left[1+\mathrm{A}(\mathrm{t}-25)+\mathrm{B}(\mathrm{t}-25)^{2}+\mathrm{C}(\mathrm{t}-25)^{3}\right]
$$

\begin{tabular}{|c|c|c|c|c|c|c|c|}
\hline $\begin{array}{c}\text { Per cent } \\
\text { alcohol } \\
\text { by weight }\end{array}$ & $A \times 10^{6}$ & $\mathbf{B} \times 10^{7}$ & $\mathbf{C} \times 10^{3}$ & $\begin{array}{c}\text { Per cent } \\
\text { alcohol } \\
\text { by weight }\end{array}$ & $\mathbf{A} \times 10^{6}$ & $\mathbf{E} \times 10^{7}$ & $\mathbf{C} \times 10^{8}$ \\
\hline $\begin{array}{r}0 \\
1 \\
2 \\
3 \\
4 \\
5 \\
6 \\
7 \\
8 \\
9 \\
10 \\
11 \\
12 \\
13 \\
14 \\
15 \\
16 \\
17 \\
18 \\
19 \\
20 \\
21 \\
22 \\
23 \\
24 \\
25 \\
26 \\
27 \\
28 \\
29 \\
30 \\
31 \\
32 \\
33 \\
34 \\
35 \\
36 \\
37 \\
38 \\
39 \\
40 \\
41 \\
42 \\
43 \\
44 \\
45 \\
46 \\
47 \\
48 \\
49 \\
50\end{array}$ & $\begin{array}{l}+257.2 \\
+259 \\
+261 \\
+264 \\
+267 \\
+272.1 \\
+278 \\
+286 \\
+295 \\
+306 \\
+318.3 \\
+331 \\
+345 \\
+360 \\
+376 \\
+392 \\
+409 \\
+427 \\
+446 \\
+465.4 \\
+485 \\
+505 \\
+525 \\
+544.6 \\
+564 \\
+584 \\
+604 \\
+623 \\
+641 \\
+658 \\
+675.2 \\
+691 \\
+706 \\
+720 \\
+734 \\
+748 \\
+760 \\
+772 \\
+784 \\
+794 \\
+804.0 \\
+814 \\
+822 \\
+831 \\
+839 \\
+847 \\
+855 \\
+862 \\
+870 \\
+876 \\
+883.1 \\
\end{array}$ & $\begin{array}{l}+49.2 \\
+50 \\
+51 \\
+51 \\
+51 \\
+51.5 \\
+52 \\
+51 \\
+51 \\
+51 \\
+50.4 \\
+50 \\
+49 \\
+48 \\
+48 \\
+47 \\
+46 \\
+45 \\
+44 \\
+43.0 \\
+42 \\
+40 \\
+39 \\
+37.2 \\
+36 \\
+34 \\
+33 \\
+32 \\
+31 \\
+30 \\
+28.5 \\
+27 \\
+26 \\
+26 \\
+25 \\
+24 \\
+24 \\
+23 \\
+23 \\
+22 \\
+22.0 \\
+22 \\
+22 \\
+22 \\
+22 \\
+22 \\
+22 \\
+22 \\
+22 \\
+22 \\
+21.9\end{array}$ & 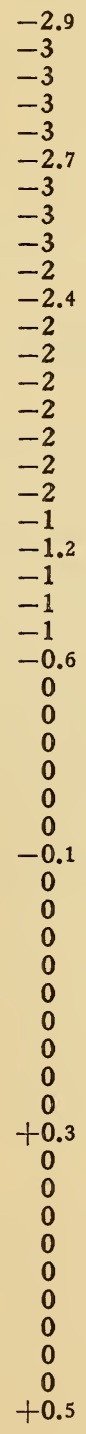 & 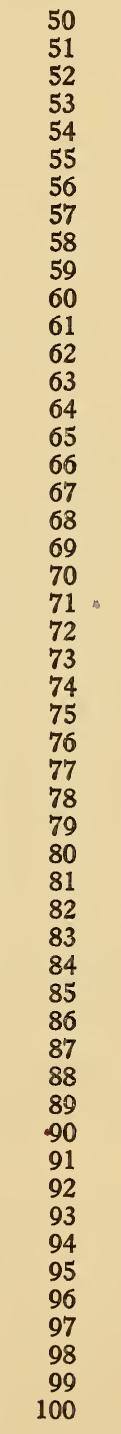 & $\begin{array}{l}+883.1 \\
+890 \\
+996 \\
+902 \\
+908 \\
+914 \\
+920 \\
+926 \\
+931 \\
+937 \\
+942.4 \\
+948 \\
+953 \\
+958 \\
+964 \\
+969 \\
+974 \\
+979 \\
+984 \\
+989 \\
+993.9 \\
+1099 \\
+1003 \\
+1008 \\
+1012 \\
+1017 \\
+1021 \\
+1026 \\
+1030 \\
+1034 \\
+1038.5 \\
+1043 \\
+1047 \\
+1051 \\
+1055 \\
+1059 \\
+1062 \\
+1066 \\
+1069 \\
+1072 \\
+1074.9 \\
+1078 \\
+1080 \\
+1084 \\
+1086 \\
+1088 \\
+1089 \\
+1091 \\
+1093 \\
+1094.3 \\
+9\end{array}$ & $\begin{array}{l}+21.9 \\
+22 \\
+22 \\
+22 \\
+22 \\
+22 \\
+22 \\
+22 \\
+22 \\
+22 \\
+22.5 \\
+23 \\
+23 \\
+23 \\
+23 \\
+23 \\
+23 \\
+23 \\
+23 \\
+23 \\
+23.4 \\
+24 \\
+24 \\
+24 \\
+24 \\
+24 \\
+24 \\
+24 \\
+24 \\
+24 \\
+23.7 \\
+24 \\
+24 \\
+24 \\
+24 \\
+24 \\
+23 \\
+23 \\
+23 \\
+23 \\
+23.0 \\
+23 \\
+23 \\
+22 \\
+22 \\
+22 \\
+21 \\
+21 \\
+20 \\
+20 \\
+19.1\end{array}$ & $\begin{array}{l}+0.5 \\
+1 \\
+1 \\
+1 \\
+1 \\
+1 \\
+1 \\
+1 \\
+1 \\
+1 \\
+0.7 \\
+1 \\
+1 \\
+1 \\
+1 \\
+1 \\
+1 \\
+1 \\
+1 \\
+1 \\
+0.9 \\
+1 \\
+1 \\
+1 \\
+1 \\
+1 \\
+1 \\
+1 \\
+1 \\
+1 \\
+0.9 \\
+1 \\
+1 \\
+1 \\
+1 \\
+1 \\
+1 \\
+1 \\
+1 \\
+1 \\
+0.9 \\
+1 \\
+1 \\
+1 \\
+1 \\
+1 \\
+1 \\
+1 \\
+1 \\
+1 \\
+0.8\end{array}$ \\
\hline
\end{tabular}





\title{
PART 3
}

\section{DENSITY OF ETHYL ALCOHOL AND OF ITS MIXTURES WITH WATER}

\author{
By N. S. Osbome
}

Part 3 consists of the determination of the density at a single temperature, $25^{\circ} \mathrm{C}$, of pure ethyl alcohol and of various mixtures of alcohol and water in accurately determined proportions and the derivation of alcoholometric tables.

\section{DESCRIPTION OF APPARATUS AND EXPERIMENTAL WORK}

The fundamental determinations of the density of pure alcohol were made simultaneously with its preparation, as previously described. The compounding of the mixtures, using portions of the same purified material, and the determination of their densities followed these fundamental determinations.

The density determinations were made partly by the method of hydrostatic weighing, described in Part 2 of this paper (p.37I), and partly by the use of specially constructed picnometers. By the use of these picnometers the effect of dissolved air upon the density of alcohol and of its mixtures was investigated to ascertain its significance in alcoholometry.

\section{THE PICNOMETERS}

Three picnometers, specially designed for the purpose on the principle of the Ostwald-Sprengel type, were used. In the construction of these picnometers the elements desired were as follows:

(a) A form adapted to the rapid attainment of the constant temperature of a surrounding water bath.

(b) Means of filling with minimum contact of liquid with air.

(c) Protection after filling from change of weight by evaporation or absorption of moisture; and

(d) Precision of filling. 
The form of the picnometers is illustrated in Figs. Io and II. They were all made of Jena I 6 irI glass and thoroughly annealed. They are adapted to immersion in the constant temperature bath

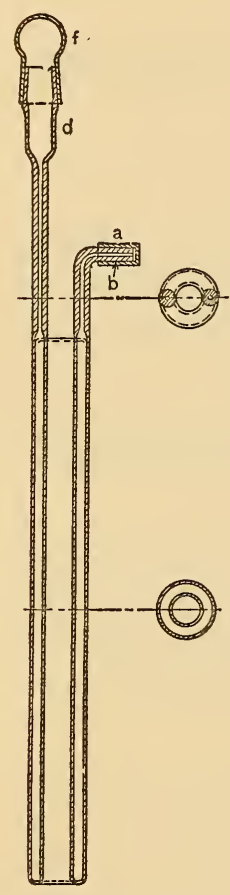

Fig. 10 (one-fourth size). already described. One of the picnometers (No. 274, Fig. II) was of the Rudolphi ${ }^{952}$ form, consisting of a hollow cylinder, which permits a rapid attainment of temperature but at expense of total volume. The others (Nos. 275 and 276 , Fig. II) were of the plain cylindrical form. The cap with stopcock attached, as shown in Fig. II, is used to control the internal pressure when filling the picnometer. The bulb containing the liquid to be investigated is joined to the picnometer by the ground joint $b$. By proper manipulation, such as inclining the picnometer at a suitable angle and properly varying the air pressure, liquid is introduced into the picnometer. With the picnometer in position in the water bath, leaving only the upper portions of the capillaries emergent, the adjustment of the quantity of liquid is approximated as the temperature approaches constancy. Liquid may be introduced if necessary by means of a pipette placed with its tip to the aperture of the capillary with proper adjustment of pressure through the tube $c$. Small quantities may be removed by means of a strip of filter paper applied at the tip of the capillary. Enough liquid is removed to bring the meniscus just to the line $e$ on the other capillary. The inside of the enlargement $d$ of the tube is

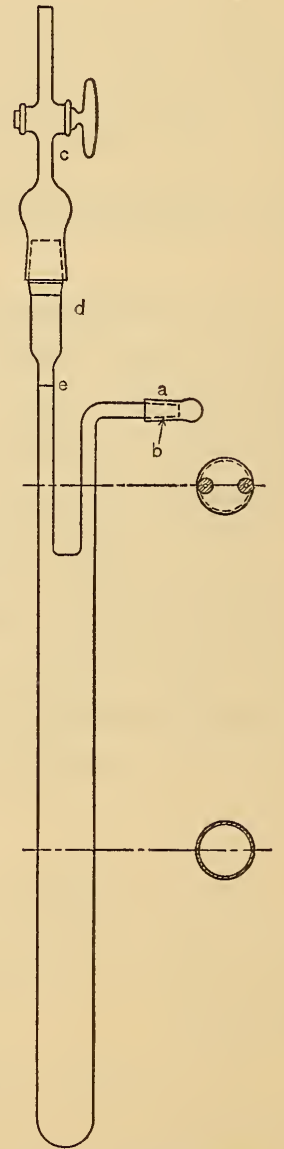

Fig. 11 (one-fourth size). dried, either by means of filter paper or by a stream of dry air.

The picnometer itself serves as a sensitive thermo-indicator, and until the temperature becomes constant the final adjustment 
of the quantity of liquid can not be made. When the temperature appears steady, 5 or io minutes more are allowed as margin of safety, and the filling is then completed. The picnometer is closed to prevent evaporation or absorption of moisture by means of the cap $f$, shown in the illustration.

The constants of these picnometers are given in Table XXXVIII.

TABLE XXXVIII

Constants of Picnometers

\begin{tabular}{c|c|c|c}
\hline Picnometer B. S. No. & External volume at $25^{\circ} \mathrm{C}$ & Mass & Internal volume at $25^{\circ} \mathrm{C}$ \\
\cline { 2 - 3 } 274 & $\mathrm{ml}$ & $\mathrm{ml}$ & $\mathrm{ml}$ \\
275 & 92.865 & 103.1393 & 46.1329 \\
276 & 124.56 & 75.8659 & 87.4046 \\
& 123.33 & 74.4672 & 86.0145 \\
\hline
\end{tabular}

For the determinations of the volumes of these picnometers the density of water at $\frac{25^{\circ}}{4} \mathrm{C}$ according to Chappuis ${ }^{1132}$ (0.997077) was used.

\section{EFFECT OF DISSOLVED AIR}

The effect upon the density of absolute alcohol caused by dissolved air was first determined by the method of hydrostatic weighing. The density of the alcohol was observed after long contact with dry air. The sample in the tube was then evacuated until no more bubbles were evolved. The density was then redetermined. Dry air was then passed into the bottom of the tube and bubbled through the alcohol and the density again determined. This was repeated on a second sample of alcohol. The results are shown in Table XXXIX.

TABLE XXXIX

Effect of Dissolved Air on Density of Alcohol

SAMPLE OF FRACTION NO. 3 I

\begin{tabular}{c|c|c}
\hline Original density at $\frac{25^{\circ}}{4} \mathrm{C}$ & Density at $\frac{25^{\circ}}{4} \mathrm{C}$ after evacuating & $\begin{array}{c}\text { Density at } \frac{25^{\circ}}{4} \mathrm{C} \text { after passing in } \\
\text { air }\end{array}$ \\
\hline 0.785094 & 0.785160 & 0.785134 \\
\hline 0.785041 & FRACTION NO. 5 I \\
\hline
\end{tabular}


Upon again saturating the alcohol with air the density did not return quite to its original value. This may be due to absorption of moisture. The above results indicate clearly that absorbed air decreases the density of absolute alcohol very appreciably. This is contrary to the experimental result obtained by Mendeléeff, ${ }^{207},{ }^{241}$ who, by taking air-free alcohol and shaking it with supposedly dry air, observed an increase in the density.

The above preliminary experiments were repeated, using the picnometers for determining the densities. In the method of hydrostatic weighing the alcohol was in contact with the air while the determination was being made, thus leaving doubt as to the completeness of the observed effect. Hence it was anticipated that more consistent and uniform results would be possible with the picnometer. The results are shown in Table XL.

TABLE XL

Effect of Dissolved Air on Density of Alcohol

SAMPLE OF ABSOLUTE ALCOHOL IN PICNOMETER NO. 274

\begin{tabular}{|c|c|c|}
\hline & $D^{25^{\circ}} \frac{1}{4}$ & Change in density \\
\hline $\begin{array}{l}\text { After evacuating to remove air. } \ldots \ldots \ldots \ldots \ldots \\
\text { After shaking with dry air............ }\end{array}$ & $\begin{array}{r}0.785120 \\
.785055\end{array}$ & 0.000065 \\
\hline
\end{tabular}

SAMPLE NO. 5 I

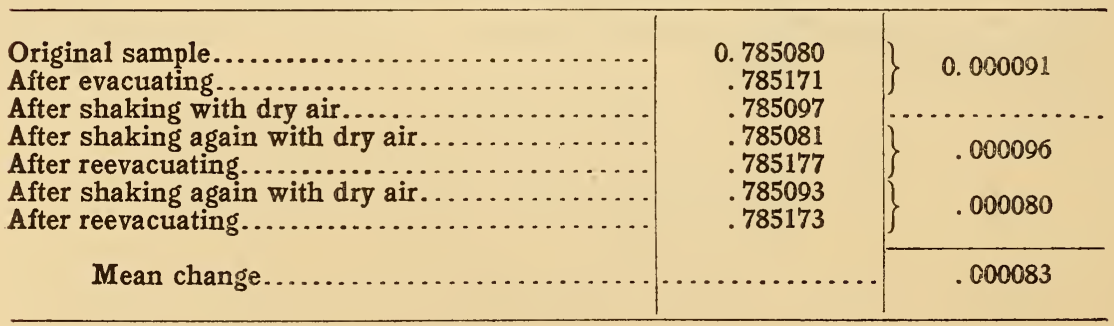

The above results demonstrate the reproducibility of the effect, although not indicating to what extent it is dependent on the temperature. The mean observed effect of dissolved air at $25^{\circ}$ is a decrease in density of 0.000083 . 
The quantity of air absorbed by absolute alcohol was approxamately determined by weighing, after evacuating to remove the air, a quantity of alcohol in a flask provided with a ground stopper, to which was attached a tube having two stopcocks with a bulb between. Dry air was admitted, shaken, and the flask again weighed. This was repeated until the weight became constant, indicating that no more air was absorbed. Ninety-three and fourteen hundredths (93.14) grams of alcohol absorbed .org gram of air at about $20^{\circ} \mathrm{C}$. This corresponds to about . $\mathrm{I} 3 \mathrm{cc}$ of air for each cubic centimeter of alcohol.

The effect of dissolved air upon the density is so significant that the condition of alcohol as to whether air free or saturated with air must be specified if the density is used as a criterion of the completeness of dehydration.

Many experimenters neglect to state whether their alcohol is air free or air saturated. Mendeléeff ${ }^{207}{ }^{241}$ states that the alcohol used by him was air free, and he used as a test for this condition the fact that when mixed with water no bubbles were given off. This does not seem to be a sufficiently definite test, since mixtures of alcohol and water may contain air, and from the low values obtained by Mendeléeff for the density of absolute alcohol and the method employed by him in obtaining it air free, it seems very doubtful if he removed more than a small part of the dissolved air.

The approximate effect of dissolved air upon the density of alcohol-water mixtures is derived later from the density determinations upon those mixtures.

\section{DETERMINATION OF THE DENSITY OF ETHYL ALCOHOL}

Having determined the magnitude of the effect of dissolved air upon the density, and having observed the greater uniformity in the density of the alcohol when saturated with air than when deprived of but left in contact with air, the density determinations to serve as criteria for comparison of different samples of supposedly pure alcohol were made in the air-saturated condition. The complete results of these determinations are given in Part I.

In this place are given only the actual determinations upon the samples, which were regarded as being the purest prepared and on 
that account chosen to establish the value for the density of absolute alcohol.

These samples are designated by the number of the experiment in their preparation as described in detail in Part I of this paper. The complete record of observations and reductions to obtain the final mean value for the density of pure ethyl alcohol at $\frac{25}{4}^{\circ} \mathrm{C}$ are given in Tables XLI to XLV.

\section{TABLE XLI}

Determinations of Density of Alcohol From Experiment IV Hydrostatic Weighing. Sinker No. 7

Date: Apr. 18, 1910. Record, vol. 646, p. 153

\begin{tabular}{|c|c|c|c|c|c|c|c|c|}
\hline \multicolumn{2}{|c|}{$\begin{array}{l}\text { Corrected tempera- } \\
\text { ture }\end{array}$} & \multirow{2}{*}{$\begin{array}{c}\text { Mean cor- } \\
\text { rected } \\
\text { tempera- } \\
\text { ture } \\
t\end{array}$} & \multirow{2}{*}{$\begin{array}{l}\text { Apparent } \\
\text { weight of } \\
\text { sinker } \\
\text { in liquid }\end{array}$} & \multirow{2}{*}{$\begin{array}{c}\text { True } \\
\text { weight of } \\
\text { sinker } \\
\text { in liquid }\end{array}$} & \multirow{2}{*}{$\begin{array}{l}\text { Volume of } \\
\text { sinker at } \\
\text { observed } \\
\text { temperature }\end{array}$} & \multirow{2}{*}{$\begin{array}{c}\text { Density of } \\
\text { liquid at } \\
\text { observed } \\
\text { temperature } \\
D_{\frac{t}{4}}^{t}\end{array}$} & \multirow{2}{*}{$\begin{array}{c}\begin{array}{c}\text { Density of } \\
\text { liquid at } \\
25^{\circ} \mathrm{C} \\
\mathrm{D} \frac{25}{4}\end{array} \\
\end{array}$} & \multirow{2}{*}{$\begin{array}{l}\text { Frac- } \\
\text { tion No. }\end{array}$} \\
\hline $\begin{array}{c}\text { Green } \\
2499\end{array}$ & $\underset{4653}{\text { Tonnelot }}$ & & & & & & & \\
\hline 25.008 & 25.010 & & 62..$_{5444}^{\mathrm{g}}$ & & & & & \\
\hline 25.008 & 25.015 & $25: 010$ & 62.5443 & 62.5358 & 47.71845 & 0.785088 & 0.785097 & 1 \\
\hline 25.013 & 25.015 & & 62.5459 & & & & & \\
\hline 25.008 & 25.020 & 25.014 & 62.5459 & 62.5373 & 47. 71845 & .785057 & .785069 & 2 \\
\hline 25.013 & 25.015 & & 62.5464 & & & & & \\
\hline 25.008 & 25.020 & $25: 014$ & 62.5464 & 62.5378 & 47. 71845 & .785046 & .785058 & 3 \\
\hline 25.018 & 25.020 & & 62.5466 & & & & & \\
\hline 25.008 & 25.015 & $25: 015$ & 62.5466 & 62.5380 & 47. 71846 & .785042 & .785055 & 4 \\
\hline 25.013 & 25.020 & & 62.5469 & & & & & \\
\hline 25.008 & 25.015 & $25: 014$ & 62.5468 & 62.5382 & 47. 71845 & .785038 & .785050 & 5 \\
\hline 25.013 & 25020 & $25: 019$ & 62.5468 & 62.5382 & 47. 71846 & .785038 & .785034 & 6 \\
\hline 25. 018 & 25.025 & & 62.5468 & & & & & \\
\hline
\end{tabular}

Thermometer corrections: No. $2499,+0.008$; No. 4653 , +0.020. Observed air density: $0.00116 \mathrm{~g} / \mathrm{cm}^{3}$. Buoyancy correction on weights: $0.0086 \mathrm{~g}$. Mass of sinker: $99.9990 \mathrm{~g}$. 


\section{TABLE XLII}

Determinations of Density of Alcohol from Experiment VII. Hydrostatic Weighing: Sinker No. 7

Date: May 11, 1910. Record, vol. 646, p. 176

\begin{tabular}{|c|c|c|c|c|c|c|c|c|}
\hline \multicolumn{2}{|c|}{$\begin{array}{c}\text { Corrected tempera- } \\
\text { ture }\end{array}$} & \multirow{2}{*}{$\begin{array}{c}\text { Mean cor- } \\
\text { rected } \\
\text { tempera- } \\
\text { ture } \\
t\end{array}$} & \multirow{2}{*}{$\begin{array}{l}\text { Apparent } \\
\text { weight of } \\
\text { sinker } \\
\text { in liquid }\end{array}$} & \multirow{2}{*}{$\begin{array}{l}\text { True } \\
\text { weight of } \\
\text { sinker } \\
\text { in liquid }\end{array}$} & \multirow{2}{*}{$\begin{array}{l}\text { Volume of } \\
\text { sinkex at } \\
\text { observed } \\
\text { temperature }\end{array}$} & \multirow{2}{*}{$\begin{array}{c}\begin{array}{c}\text { Density of } \\
\text { liquid at } \\
\text { observed } \\
\text { temperature }\end{array} \\
D_{\frac{t}{4}}^{t}\end{array}$} & \multirow{2}{*}{$\begin{array}{c}\text { Density of } \\
\text { liquid at } \\
25^{\circ} \mathrm{C} \\
\mathrm{D} \frac{25}{4}\end{array}$} & \multirow{2}{*}{$\begin{array}{l}\text { Frac- } \\
\text { tion No. }\end{array}$} \\
\hline $\begin{array}{c}\text { Green } \\
2499\end{array}$ & $\begin{array}{c}\text { Tonnelot } \\
4653\end{array}$ & & & & & & & \\
\hline 25.028 & 25.030 & & g & & & & & \\
\hline 25.028 & 25.035 & 25.030 & 62.5469 & 62.5382 & 47. 71847 & 0.785038 & 0.785064 & 1 \\
\hline 25.008 & 25.020 & & & & & & & \\
\hline 25.013 & 25.020 & 25.015 & 62.5465 & 62.5378 & 47. 71846 & .785046 & .785059 & 2 \\
\hline 25.013 & 25.020 & & & & & & & \\
\hline 25.013 & 25.020 & 25.010 & 62.5465 & 62.5378 & 47.71846 & .785046 & .785060 & 3 \\
\hline
\end{tabular}

Thermometer corrections: No. $2499,+0.008$; No. $4653,+0.020$. Observed air density: $0.00116 \mathrm{~g} / \mathrm{cm}^{3}$. Buoyancy correction on weights: $0.0087 \mathrm{~g}$. Mass of sinker: $99.9990 \mathrm{~g}$. 


\section{TABLE XLIII}

Determinations of Density of Absolute Alcohol from Experiment XII Hydrostatic Weighing: Sinker No. 7

Date: Apr. 7, 11, 12, 1910 . Record, vol. 646, p. 147

\begin{tabular}{|c|c|c|c|c|c|c|c|c|}
\hline \multicolumn{2}{|c|}{$\begin{array}{l}\text { Corrected tempera- } \\
\text { ture }\end{array}$} & \multirow{2}{*}{$\begin{array}{c}\text { Mean cor- } \\
\text { rected } \\
\text { tempera- } \\
\text { ture } \\
t\end{array}$} & \multirow{2}{*}{$\begin{array}{l}\text { Apparent } \\
\text { weight of } \\
\text { sinker } \\
\text { in liquid }\end{array}$} & \multirow{2}{*}{$\begin{array}{c}\text { True } \\
\text { weight of } \\
\text { sinker } \\
\text { in liquid }\end{array}$} & \multirow{2}{*}{$\begin{array}{l}\text { Volume of } \\
\text { sinker at } \\
\text { observed } \\
\text { temperature }\end{array}$} & \multirow{2}{*}{ 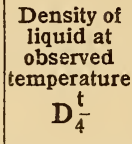 } & \multirow{2}{*}{$\begin{array}{c}\text { Density of } \\
\text { liquid a } \\
25^{\circ} \mathrm{C} \\
\mathrm{D}^{25}\end{array}$} & \multirow{2}{*}{$\begin{array}{l}\text { Frac- } \\
\text { tion No. }\end{array}$} \\
\hline $\begin{array}{l}\text { Green } \\
2499\end{array}$ & $\begin{array}{c}\text { Tonnelot } \\
4653\end{array}$ & & & & & & & \\
\hline 25.008 & 25.010 & & $62 . \stackrel{g}{5} 465$ & & & & & \\
\hline 25. 008 & 25.020 & 25. 012 & 62.5466 & 62.5378 & 47.71845 & 0. 785046 & 0. 785056 & 1 \\
\hline 25.008 & 25.020 & & 62.5464 & & & & & \\
\hline 25.023 & 25.020 & 25. 018 & 62.5466 & 62.5377 & 47. 71846 & .785048 & .785053 & $c 1$ \\
\hline 25. 013 & 25.015 & & $62.546^{?}$ & & & & & \\
\hline 25.018 & 25.020 & 25.016 & 62.5463 & 62.5375 & 47. 71846 & .785053 & .785067 & 2 \\
\hline 25.013 & 25.015 & & 62.5469 & & & & & \\
\hline 25.018 & 25.025 & 25.018 & 62.5471 & 02.5382 & 47.71840 & .785038 & .785053 & 3 \\
\hline 24. 998 & 25.005 & & 62.5464 & & & & & \\
\hline 25.003 & 25.015 & 25.005 & 62.5465 & 02.5377 & 47.71844 & . 785049 & .785053 & 4 \\
\hline 25.013 & 25.020 & & 62.5463 & & & & & \\
\hline 25.008 & 25.020 & 25.015 & 62.5465 & 02.5370 & 47.71840 & .785050 & .785063 & 5 \\
\hline 24.993 & 25.000 & & 62.5460 & & & & & \\
\hline 24.993 & 25.000 & 24.996 & 62.5459 & 62.5372 & 47. 7144 & . 785059 & .785056 & 6 \\
\hline
\end{tabular}

c After passing dry air through.

Thermometer corrections: No, 2499, +0.008; No. 4653, +0.020. Observed air density: $0.00118 \mathrm{~g} / \mathrm{cm}^{3}$. Buoyancy correction on weights: $0.0088 \mathrm{~g}$. Mass of sinker: $99.9990 \mathrm{~g}$. 


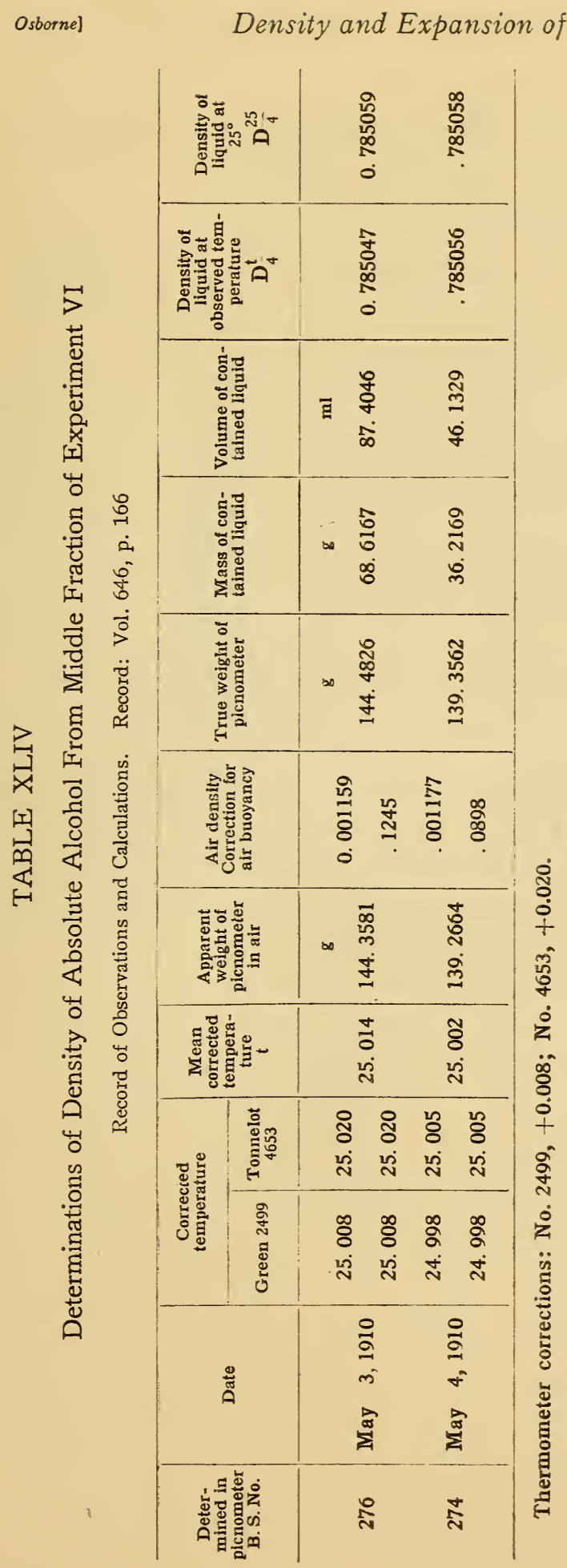




\section{TABLE XLV}

The Density at $\frac{25^{\circ}}{4}$ of Pure Ethyl Alcohol Saturated with Air. Assembled Results of Most Satisfactory Experiments

\begin{tabular}{|c|c|c|c|c|}
\hline Experiment number & $\begin{array}{l}\text { Fraction } \\
\text { number }\end{array}$ & Method of determination & $\begin{array}{c}\text { Density at } \frac{25^{\circ}}{4} \\
\mathrm{D}_{\frac{25}{4}}\end{array}$ & $\begin{array}{c}\text { Observed } \\
\text { density- } \\
\text { mean density } \\
\times 10^{6}\end{array}$ \\
\hline $\begin{array}{l}\text { VI... } \\
\text { VII. . } \\
\text { XII. . }\end{array}$ & $\begin{array}{l}3 \\
4 \\
5 \\
6 \\
2 \\
2 \\
1 \\
2 \\
3 \\
1 \\
2 \\
3 \\
4 \\
5 \\
6\end{array}$ & 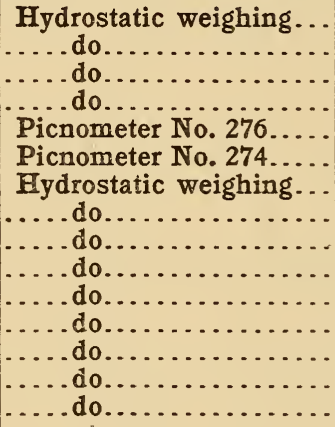 & $\begin{array}{l}0.785058 \\
.785055 \\
.785050 \\
.785054 \\
.785059 \\
.785058 \\
.785064 \\
.785059 \\
.785060 \\
.785063 \\
.785067 \\
.785053 \\
.785053 \\
.785063 \\
.785056\end{array}$ & $\begin{array}{r}0 \\
-3 \\
-8 \\
-4 \\
+1 \\
0 \\
+6 \\
+1 \\
+2 \\
+5 \\
+9 \\
-5 \\
-5 \\
+5 \\
-2\end{array}$ \\
\hline Mean. & & & .785058 & \\
\hline
\end{tabular}

Comparative examination of the results of the density determinations furnishes an index of the orcier of magnitude of the accidental errors. In Table XIV the average deviation from the mean of the 15 determinations is about 0.000004 . The error of the mean due to accidental sources is within 0.000001 . 
The absolute accuracy of the densities is limited by the precision with which the thermometers have served to reproduce the International Hydrogen Scale. Two thermometers that were compared with the primary standards of the Bureau were always used. The corrected temperature indications of these thermometers rarely differed by as much as $\mathrm{O}^{\circ}$.or. However, in consequence of the uncertainties inherent in the ice-point determinations, the effect of sticking of the meniscus, of small errors in reading, and the assumptions concerning the properties of verre dur glass that are necessarily made in the reproduction of the International Hydrogen Scale, the order of accuracy that has been attained in the reproduction of this temperature scale is, as nearly as can be estimated, about $0^{\circ}$.OI $\mathrm{C}$, corresponding to about 0.000009 in density of pure alcohol at $25^{\circ} \mathrm{C}$. Hence an accuracy of I unit of the fifth decimal place for this constant is all that can be expected.

As the result of these experiments 0.78506 is taken as the density at $25^{\circ} \mathrm{C}$ in grams per milliliter of pure ethyl alcohol saturated with air at ordinary atmospheric pressure.

\section{PREPARATION OF THE MIXTURES-APPARATUS AND METHOD USED}

In order to render the preparation of the mixtures as free as possible from causes of error in determining the proportions of alcohol and water, the apparatus shown in Fig. 12 was employed. It has been shown (p. 408) that pure alcohol at $25^{\circ} \mathrm{C}$ absorbs about 0.02 per cent of its own weight of air, which diminishes the density about 0.00008 . Marek ${ }^{614}$ has shown that the absorption of air does not appreciably change the density of water at $25^{\circ} \mathrm{C}$.

When alcohol and water both saturated with air are mixed, air is given off. This constitutes a source of error in the composition which can not exceed 0.02 per cent and is doubtless considerably less. This error may, however, be avoided by using water and alcohol deprived of air. Another possible source of error when the alcohol and water used in mixtures are weighed at atmospheric pressure is the difficulty in ascertaining the density of the mixture of air and vapor in the vessel above the liquid. To avoid the two errors mentioned above and to enable also an approximate determination of the effect of dissolved air upon the mixtures of alcohol 
and water to be made, the mixing apparatus was constructed to permit the weighing of the liquids when evacuated to their vapor pressure. Referring to Fig. 12 , it is seen that the apparatus consists of three parts-a bulb $B$ with one opening, a three-way stopcock $D$, and a funnel shaped vessel $A$, all provided with ground joints to permit their being joined together. In use the ground joints and the stopcock were lubricated sufficiently to render

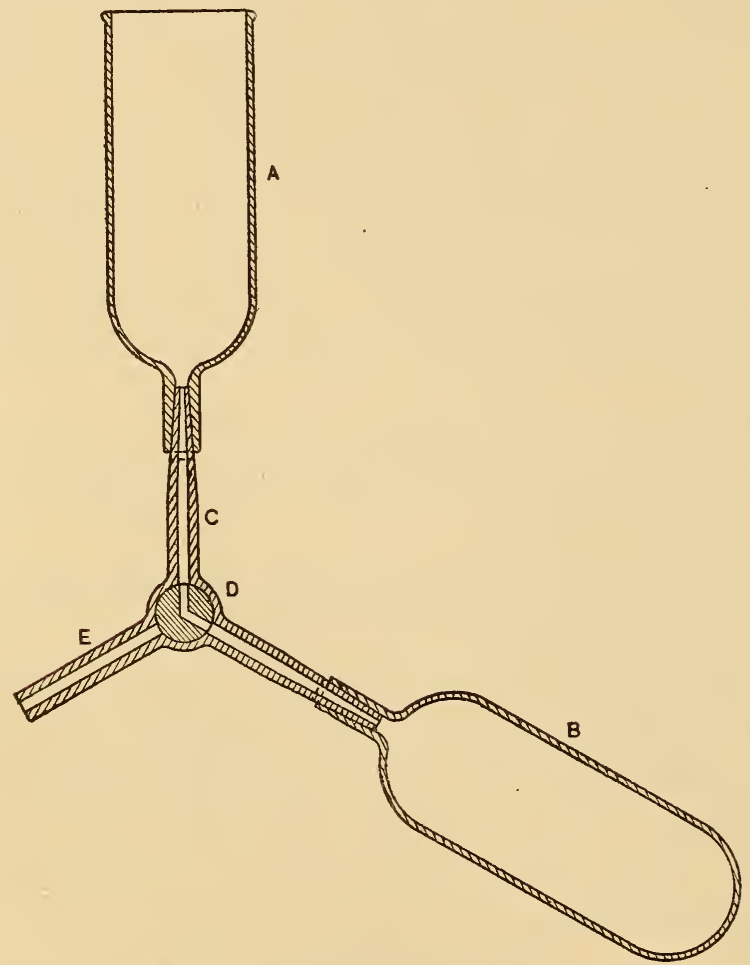

Fig. 12.-Mixing apparatus (one-third size). them air tight, using a rather soft mixture of rubber and vaseline. The procedure in making a mixture was as follows:

The bulb with the three-way stopcock attached was first exhausted to remove the air and then closed and weighed. Next dry air was admitted and the stopcock removed. A suitable quantity of absolute alcohol was transferred to the bulb by means of a burette, only air which had been dried by $\mathrm{P}_{2} \mathrm{O}_{5}$ being allowed to come in contact with the alcohol. The stopcock was replaced and the bulb again evacuated to remove the dissolved air from the alcohol. By repeated exhaustion and thorough shaking of the bulb the alcohol was freed from air. The stopcock was turned so as to close the passage to the bulb and connect the two other passages $C$ and $E$ which were then thoroughly dried by forcing through a current of dry air. The closed bulb containing only air-free alcohol and alcohol vapor was then weighed. 
The water used in making the mixtures was freed from air by subjecting it in a flask to repeated exhaustion to a low pressure and shaking until no more air could be removed. The amount of water required to make a mixture of the desired concentration was calculated from the known quantity of alcohol already in the bulb. The tubular opening in the stopcock was first filled with water just to the bottom of the funnel and then closed. The calculated amount of water was then measured into the funnel by means of a burette. On turning the stopcock to connect the funnel with the bulb the outside atmospheric pressure forced the water into the exhausted bulb containing the alcohol. When the water again reached just to the bottom of the funnel the cock was turned so as to close the bulb and open the other passages. The funnel was removed and the cock again dried as before, after which the bulb containing the air-free mixture was weighed. Thus the relative proportions of alcohol and water were determined. Notwithstanding these precautions for excluding air from the mixtures a slight amount could still be detected in the form of bubbles evolved when the water was mixed with the alcohol at the very low pressure present, but it was certainly much less in amount than would be present by any method of mixing at atmospheric pressure. The mixtures may be considered practically air free. The possibility of the grease being dissolved by the mixture was investigated by evaporating $75 \mathrm{cc}$ of a 95 per cent mixture. Only $0.2 \mathrm{mg}$ of residue was found ( $\frac{1}{300000}$ part).

The dimensions of this mixing bulb are as follows:

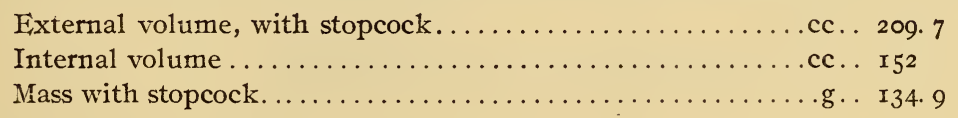

The balance used in making the mixtures was No. 5485, a Rueprecht analytical balance of 6oo-g load, similar in design to that used for the density determinations and described on page 377. This balance was sensitive to $0.5 \mathrm{mg}$. Corrections for displaced air were applied to all weighings. The weights used in making the mixtures were set No. $5^{1} 57$, the same as those used for the density determinations and described on page 377 , except that those from $500 \mathrm{mg}$ to $\mathrm{Io} \mathrm{mg}$ were the ones belonging to the 
balance. By previous test these were known to have no significant errors.

\section{MATERIALS USED}

The samples of absolute alcohol used in making the mixtures were portions of the distillates obtained in Experiments IV and XII, described in Part I. The products of these experiments were regarded as of the greatest purity obtained.

The different samples of alcohol and the designations of the mixtures made from each, together with the determinations of density made at the time of use, are as follows:

\section{SAMPLE}

This sample was composed of fractions Nos. 2, 3, 4, and 5 from Experiment XII.

The density determinations were as follows:

\begin{tabular}{|c|c|c|}
\hline Date & How made & $D^{25^{\circ}} \frac{4^{\circ}}{}$ \\
\hline $\begin{array}{l}\quad 1910 \\
\text { Apr. } 7 \ldots \ldots \ldots \ldots \ldots \ldots \ldots \ldots \\
\text { Apr. } 22 \ldots \ldots \ldots \ldots \ldots \ldots \ldots \\
\text { Apr. } 29 \ldots \ldots \ldots \ldots \ldots \ldots\end{array}$ & $\begin{array}{l}\text { Hydrostatic weighing } \ldots \ldots \ldots \ldots \ldots \ldots \ldots \ldots \ldots \\
\text { Picnometer No. } 275 \ldots \ldots \ldots \ldots \ldots \ldots \ldots \\
\text { Picnometer No. } 276 \ldots \ldots \ldots \ldots \ldots \ldots\end{array}$ & $\begin{array}{r}0.785058 \\
.785055 \\
.785043\end{array}$ \\
\hline
\end{tabular}

From this sample were made mixtures designated as $95 \mathrm{D}$, $95 \mathrm{E}, 95 \mathrm{~F}, 90 \mathrm{D}$, and $90 \mathrm{E}$.

\section{SAMPLE 2}

This sample was composed of fractions $B, C$, and D from Experiment IV.

The density determinations were as follows:

\begin{tabular}{|c|c|c|}
\hline Date & How made & $\mathrm{D} \frac{25^{\circ}}{4^{\circ}}$ \\
\hline 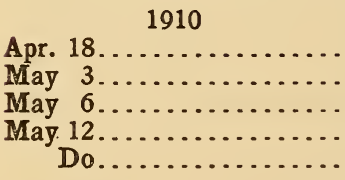 & 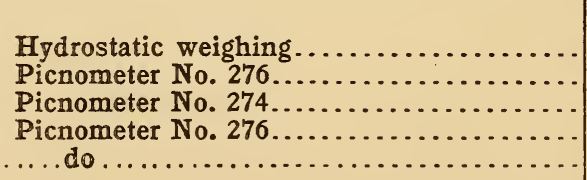 & $\begin{array}{r}0.785058 \\
.785053 \\
.785044 \\
.785055 \\
.785047\end{array}$ \\
\hline
\end{tabular}

From this sample were made mixtures designated $80 \mathrm{D}, 70 \mathrm{D}$, $60 \mathrm{D}, 50 \mathrm{D}, 40 \mathrm{D} .65 \mathrm{D}, 30 \mathrm{D}, 20 \mathrm{D}$, ro $\mathrm{D}$, and $55 \mathrm{D}$. 
SAMPLE 3

This sample was composed of fractions $2,3,4,5$, and 6 from Experiment IV. These portions are those upon which were made the original density determinations for Experiment IV. The density determinations were as follows:

\begin{tabular}{|c|c|c|}
\hline Date & How made & $\mathrm{D} \frac{25}{4}$ \\
\hline $\begin{array}{l}\quad 1910 \\
\text { Apr. } 18 \ldots \ldots . \\
\text { May } 25 \ldots \ldots . \\
\text { May } 26 \ldots \ldots .\end{array}$ & $\begin{array}{l}\text { Hydrostatic weighing.. } \\
\text { Picnometer No. 276... } \\
\ldots \ldots \text {. do............... }\end{array}$ & $\begin{array}{r}0.785057 \\
.785069 \\
.785052\end{array}$ \\
\hline
\end{tabular}

From this sample were made mixtures designated $75 \mathrm{D}, 85 \mathrm{D}$, $45 \mathrm{D}, 35 \mathrm{D}$.

SAMPLE 4

This sample was fraction A from Experiment IV. The density determinations were as follows:

\begin{tabular}{|c|c|c|}
\hline Date & How made & $\mathrm{D} \frac{25}{4}$ \\
\hline $\begin{array}{l}\quad 1910 \\
\text { Apr. } 18 \ldots \ldots \ldots \\
\text { July } 5 \ldots \ldots \ldots\end{array}$ & $\begin{array}{l} \\
\text { Hydrostatic weighing } \ldots \ldots \ldots \ldots, \ldots, \ldots, \ldots\end{array}$ & $\begin{array}{r}0.785084 \\
.785088\end{array}$ \\
\hline
\end{tabular}

From this sample were made mixtures designated $25 \mathrm{D}$, I $5 \mathrm{D}$, $5 \mathrm{D}, 2 \mathrm{D}, 6 \mathrm{D}, 99 \mathrm{D}$, and $98 \mathrm{D}$.

With the exception of sample 4 , the original density determinations indicated these samples to be as free from water as any produced. The determinations at different dates show that within limits of experimental error no change in density had occurred. This was to be expected, since the portions were kept in bottles with well-ground stoppers, the bottles themselves being kept in a desiccator containing lime. In transferring the alcohol from one vessel to another air was always used which had been dried by phosphorous pentoxide, thus avoiding contamination by atmospheric moisture.

Sample 4 shows a density higher than that determined for the purest alcohol, and in calculating the percentage of the mixtures the percentage of alcohol in this sample is taken as 99.992 , this figure corresponding to the density 0.785086 .

$77398^{\circ}-\mathrm{I} 3 \longrightarrow 7$ 


\section{EXPERIMENTAL WORK AND REDUCTION OF RESULTS}

The record of the preparation of the mixtures is given in journal form in Table XIVI.

Several of the mixtures found necessary for interpolation purposes, of such proportions that the exclusion of air in their preparation was not considered essential, were made in an ordinary weighing flask at atmospheric pressure and without evacuating, as shown in the second part of Table XLVI. The record of all the density determinations made upon the mixtures is given in journal form in Table XLVII.

\section{TABLE XLVI}

Record of Preparation of Mixtures

AIR-FREE MIXTURES MADE IN SPECIAL MIXING BULB

\begin{tabular}{|c|c|c|c|c|c|}
\hline $\begin{array}{l}\text { Designation of } \\
\text { mixture }\end{array}$ & $\begin{array}{c}\text { Made from } \\
\text { sample } \\
\text { No. }\end{array}$ & $\begin{array}{l}\text { Date when } \\
\text { made }\end{array}$ & $\begin{array}{l}\text { True weight of } \\
\text { alcohol }\end{array}$ & $\begin{array}{c}\text { True weight of } \\
\text { mixture }\end{array}$ & $\begin{array}{l}\text { Per cent alcohol } \\
\text { in mixture }\end{array}$ \\
\hline $\begin{array}{l}95 \mathrm{D} \ldots \ldots \ldots \\
95 \mathrm{E} \ldots \ldots \\
95 \mathrm{~F} \ldots \ldots \ldots \\
90 \mathrm{D} \ldots \ldots \ldots \\
90 \mathrm{E} \ldots \ldots \ldots \ldots\end{array}$ & $\begin{array}{l}1 \\
1 \\
1 \\
1 \\
1\end{array}$ & $\begin{array}{c}1910 \\
\text { Apr. } 23 \ldots \\
\text { Apr. } 25 \ldots \\
\text { Apr. } 26 \ldots \\
\ldots \text { do...... } \\
\text { Apr. } 30 \ldots\end{array}$ & $\begin{array}{r}g \\
66.202 \\
73.570 \\
101.054 \\
90.496 \\
93.542\end{array}$ & $\begin{array}{r}g \\
69.820 \\
77.501 \\
106.414 \\
100.543 \\
103.931\end{array}$ & $\begin{array}{l}94.818 \\
94.928 \\
94.963 \\
90.007 \\
90.004\end{array}$ \\
\hline $\begin{array}{l}80 \mathrm{D} \ldots \ldots \\
70 \mathrm{D} \ldots \ldots \ldots \\
60 \mathrm{D} \ldots \ldots \ldots \\
50 \mathrm{D} \ldots \ldots \ldots \\
40 \mathrm{D} \ldots \ldots \ldots\end{array}$ & $\begin{array}{l}2 \\
2 \\
2 \\
2 \\
2\end{array}$ & $\begin{array}{l}\text { May } 4 . . . \\
\text { Mado.... } \\
\text { May } 5 . . . \\
\text { May } 6 . . . \\
\text { May } 7 . . .\end{array}$ & $\begin{array}{l}79.350 \\
79.624 \\
75.695 \\
61.657 \\
51.249\end{array}$ & $\begin{array}{r}99.254 \\
113.679 \\
126.018 \\
123.319 \\
126.168\end{array}$ & $\begin{array}{l}79.946 \\
70.043 \\
60.067 \\
49.998 \\
40.651\end{array}$ \\
\hline $\begin{array}{l}65 \mathrm{D} \ldots \ldots \\
30 \mathrm{D} \ldots \ldots \\
20 \mathrm{D} \ldots \ldots \ldots \\
10 \mathrm{D} \ldots \ldots \ldots \\
55 \mathrm{D} \ldots \ldots \ldots\end{array}$ & $\begin{array}{l}2 \\
2 \\
2 \\
2 \\
2\end{array}$ & $\begin{array}{l}\text { May } 9 . . . . \\
\ldots \text { do...... } \\
\text { May } 10 . . . \\
\text { May } 11 \ldots . \\
\text { May } 13 . . .\end{array}$ & $\begin{array}{l}79.683 \\
39.894 \\
27.077 \\
13.434 \\
66.701\end{array}$ & $\begin{array}{l}122.586 \\
132.968 \\
135.321 \\
134.231 \\
121.336\end{array}$ & $\begin{array}{l}65.002 \\
30.003 \\
20.009 \\
10.008 \\
54.972\end{array}$ \\
\hline $\begin{array}{l}75 \mathrm{D} \ldots \ldots . . . \\
85 \mathrm{D} \ldots \ldots . . . \\
45 \mathrm{D} \ldots \ldots . . . \\
35 \mathrm{D} . \ldots . . .\end{array}$ & $\begin{array}{l}3 \\
3 \\
3 \\
3\end{array}$ & $\begin{array}{l}\text { May } 25 \ldots . . \\
\text { May } 26 \ldots . \\
\text { May } 27 \ldots . \\
\text { May } 28 . . .\end{array}$ & $\begin{array}{l}66.413 \\
92.576 \\
58.140 \\
47.300\end{array}$ & $\begin{array}{r}88.592 \\
108.868 \\
129.345 \\
134.876\end{array}$ & $\begin{array}{l}74.965 \\
85.035 \\
44.950 \\
35.069\end{array}$ \\
\hline $\begin{array}{l}25 \mathrm{D} \ldots \ldots \ldots \\
15 \mathrm{D} \ldots \ldots \ldots \\
5 \mathrm{D} \ldots \ldots \ldots\end{array}$ & $\begin{array}{l}4 \\
4 \\
4\end{array}$ & $\begin{array}{l}\text { June } 1 . . . \\
\text { June } 3 . . . \\
. . \text { do..... }\end{array}$ & $\begin{array}{r}34.798 \\
20.243 \\
6.984\end{array}$ & $\begin{array}{l}138.692 \\
134.845 \\
139.859\end{array}$ & $\begin{array}{r}d 25.088 \\
d 15.010 \\
4.994\end{array}$ \\
\hline
\end{tabular}

MIXTURES MADE IN ORDINARY FLASK WITHOUT EXCLUDING AIR

\begin{tabular}{|c|c|c|c|c|c|}
\hline $\begin{array}{l}2 \mathrm{D} \ldots \ldots \\
6 \mathrm{D} \ldots \ldots \\
99 \mathrm{D} \ldots \ldots \ldots\end{array}$ & $\begin{array}{l}4 \\
4 \\
4 \\
4\end{array}$ & 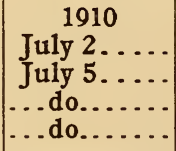 & $\begin{array}{r}\text { g. } \\
2.314 \\
6.891 \\
91.774 \\
90.471\end{array}$ & $\begin{array}{r}g \\
116.407 \\
115.888 \\
92.732 \\
92.310\end{array}$ & $\begin{array}{r}1.987 \\
5.946 \\
d 98.957 \\
d 97.998\end{array}$ \\
\hline
\end{tabular}




\section{TABLE XLVII}

\section{Record of Determinations of Density of Mixtures}

Assembled Results are Given in Table XLVIII

\begin{tabular}{|c|c|c|c|c|c|c|}
\hline & $\begin{array}{l}\text { Date of } \\
\text { density de- } \\
\text { termination }\end{array}$ & Condition of mixture & Method of & $\begin{array}{c}\text { ture of } \\
\text { determi- } \\
\text { nation } \\
t\end{array}$ & $D_{4}^{t}$ & $\mathrm{D} \frac{25}{4}$ \\
\hline - & $\begin{array}{l}1910 \\
\text { Apr. } 23 \\
\ldots \text { do...... } \\
\text { Apr. } 25 \\
\text { A.do...... }\end{array}$ & $\begin{array}{l}\text { Air free.... . } \\
\text { Air saturated. } \\
\text { A... do.... . . . } \\
\text { Air free.... }\end{array}$ & 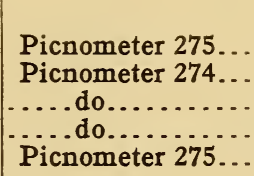 & $\begin{array}{l}24.988 \\
25.028 \\
25.016 \\
24.997 \\
24.990\end{array}$ & $\begin{array}{r}0.800486 \\
.800440 \\
.800427 \\
.800431 \\
.800160\end{array}$ & $\begin{array}{r}0.80 \\
.80 \\
.80 \\
.80 \\
.80\end{array}$ \\
\hline F. & $\begin{array}{c}\text { Apr. } \quad 26 \\
\ldots \text { do..... } \\
\ldots \text {.do..... } \\
\ldots \text {. do..... }\end{array}$ & $\begin{array}{l}\ldots \ldots \\
\mathrm{Air} \\
\ldots \ldots \\
\ldots\end{array}$ & \begin{tabular}{l}
$\ldots . . d$ \\
$\ldots \ldots d$ \\
\hdashline$\ldots d$ \\
$H y d r d$ \\
$\ldots . . d$
\end{tabular} & & & $\begin{array}{l}.8 \\
.8 \\
.8 \\
.8 \\
.8\end{array}$ \\
\hline $\begin{array}{l}\mathrm{F} \\
\mathrm{D} \\
\mathrm{D} \\
\mathrm{D}\end{array}$ & $\begin{array}{l}\text { Apr. } 27 \\
\ldots \text { do..... } \\
\text { Apr. } 29\end{array}$ & $\begin{array}{l}\text { Air } \mathrm{fr} \\
\text { Air } \mathrm{s} \\
. . . .\end{array}$ & $\begin{array}{c}\ldots . . . d \\
\text { Picno } \\
\text { Hydro }\end{array}$ & & $\begin{array}{l}.80 \\
.81 \\
.81 \\
.81\end{array}$ & $\begin{array}{l}.80 \\
.81 \\
.81 \\
.81\end{array}$ \\
\hline $\begin{array}{l}80 \mathrm{D} \\
80 \mathrm{D}\end{array}$ & 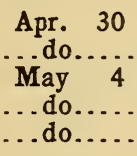 & $\begin{array}{l}\text { Air } \mathrm{fr} \\
\text { Air } \mathrm{s} \\
\text { Air } \mathrm{fr} \\
\text { Air } \mathrm{s} \\
\ldots . . \mathrm{d}\end{array}$ & \begin{tabular}{c} 
Picno \\
$\ldots \ldots d$ \\
$\ldots \ldots . d$ \\
\hdashline Hydrc
\end{tabular} & & & \\
\hline $\mathrm{D}$ & $\begin{array}{l}\text { May } \\
\text { May } \\
\text {...do. }\end{array}$ & $\begin{array}{l}\text { Air fr } \\
\text { Air sa } \\
\text { Air fr } \\
\text { Air sa } \\
\ldots . . \text { d }\end{array}$ & $\begin{array}{l}\text { Picn } \\
\text { Hydr } \\
\text { Picn } \\
\text { Picno }\end{array}$ & & & $\begin{array}{l}.88686 \\
.88684 \\
.88682\end{array}$ \\
\hline $\begin{array}{l}50 \mathrm{D} . \\
50 \mathrm{D} . \\
50 \mathrm{D} .\end{array}$ & $\begin{array}{c}\text { May } 6 \\
\ldots \text { do..... } \\
\text { Mado... } 7 \\
\text { Mado.... }\end{array}$ & $\begin{array}{l}\text { Air free...... } \\
\text { Air saturated. } \\
\text {... do....... } \\
\text { Air free..... }\end{array}$ & $\begin{array}{l}\text { Hydro } \\
\text { Picnor } \\
\text { Picnor } \\
\text { Picnor }\end{array}$ & & & $\begin{array}{r}.90986 \\
.90986 \\
.90985 \\
.93013\end{array}$ \\
\hline $\begin{array}{l}65 \mathrm{D} . \\
30 \mathrm{D} . \\
30 \mathrm{D} .\end{array}$ & $\begin{array}{l}\text { May } 9 \\
\text { Mdo...... } \\
\text { May } 10 \\
\text {..do...... }\end{array}$ & $\begin{array}{l}\text { Air } \\
\text { Air } \\
\text { Air } \\
\text { Air } \\
\text { Air }\end{array}$ & $\ldots . d$ & & & $\begin{array}{r}.930135 \\
.875276 \\
.875264 \\
.950685 \\
.950667\end{array}$ \\
\hline $\begin{array}{l}10 \mathrm{D} \\
10 \mathrm{D} \\
55 \mathrm{D}\end{array}$ & $\begin{array}{l}\text { do.... } \\
\text { May } 12 \\
\text { May } 13\end{array}$ & $\begin{array}{l}\text { Air } \\
\text { Air } \\
\text { Air } \\
\text { Air } \\
\text { Air }\end{array}$ & . & $\begin{array}{l}24.983 \\
24.988 \\
25.000 \\
25.000 \\
24.990\end{array}$ & $\begin{array}{r}.966394 \\
.966380 \\
.980431 \\
.980422 \\
.898584\end{array}$ & $\begin{array}{r}.966379 \\
.980431 \\
.980422 \\
.898576\end{array}$ \\
\hline $\begin{array}{l}75 \mathrm{D} \\
75 \mathrm{D} \\
85 \mathrm{D}\end{array}$ & $\begin{array}{l}\text { May } 25 \\
\text { May } 26\end{array}$ & $\begin{array}{l}\text { Air } \\
\text { Air } \\
\text { Air } \\
\text { Air }\end{array}$ & & $\begin{array}{l}24.989 \\
24.986 \\
24.970 \\
24.994 \\
24.996\end{array}$ & $\begin{array}{r}.898575 \\
.851456 \\
.851447 \\
.826547 \\
.826511\end{array}$ & $\begin{array}{l}.851444 \\
.851421 \\
.826542 \\
.826507\end{array}$ \\
\hline
\end{tabular}


TABLE XLVII-Continued

Record of Determinations of Density of Mixtures-Continued

\begin{tabular}{|c|c|c|c|c|c|c|}
\hline $\begin{array}{l}\text { Designa- } \\
\text { tion of } \\
\text { mixture }\end{array}$ & $\begin{array}{c}\text { Date of } \\
\text { density de- } \\
\text { termination }\end{array}$ & Condition of mixture & $\begin{array}{l}\text { Method of determina- } \\
\text { tion }\end{array}$ & $\begin{array}{c}\text { Tempera- } \\
\text { ture of } \\
\text { determi- } \\
\text { nation } \\
t\end{array}$ & $D_{\frac{1}{4}}^{t}$ & $\mathrm{D} \frac{25}{4}$ \\
\hline $\begin{array}{l}45 \mathrm{D} \ldots \\
45 \mathrm{D} \ldots \\
35 \mathrm{D} \ldots \\
35 \mathrm{D} \ldots \\
25 \mathrm{D} \ldots\end{array}$ & $\begin{array}{c}1910 \\
\text { May } 27 \\
\text { May } 28 \\
\text { May } 28 \\
\text { June } 2\end{array}$ & $\begin{array}{l}\text { Air free...... } \\
\text { Air saturated. } \\
\text { Air free....... } \\
\text { Air saturated. } \\
\text { Air free...... }\end{array}$ & 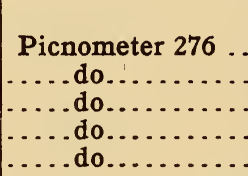 & $\begin{array}{l}24.983 \\
24.973 \\
24.980 \\
24.986 \\
24.983\end{array}$ & $\begin{array}{r}0.920993 \\
.920980 \\
.941343 \\
.941336 \\
.958810\end{array}$ & $\begin{array}{r}0.920980 \\
.920959 \\
.941329 \\
.941326 \\
.958800\end{array}$ \\
\hline $\begin{array}{l}25 \mathrm{D} . \\
15 \mathrm{D} . \\
15 \mathrm{D} . \\
5 \mathrm{D} . \\
5 \mathrm{D} .\end{array}$ & $\begin{array}{l}\text { June } 3 \\
\text { Jundo...... } \\
\text { June } 6 \\
. \text { do..... }\end{array}$ & $\begin{array}{l}\text { Air saturated. } \\
\text { Air free...... } \\
\text { Air saturated. } \\
\text { Air free...... } \\
\text { Air saturated. }\end{array}$ & 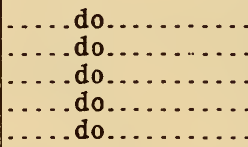 & $\begin{array}{l}24.983 \\
24.986 \\
24.980 \\
24.992 \\
24.996\end{array}$ & $\begin{array}{l}.958820 \\
.973333 \\
.973339 \\
.988171 \\
.988177\end{array}$ & $\begin{array}{r}.958810 \\
.973328 \\
.973331 \\
.988169 \\
.988176\end{array}$ \\
\hline $\begin{array}{rl}2 & \mathrm{D} . . \\
6 & \mathrm{D} . . \\
99 & \mathrm{D} . \\
98 \mathrm{D} . .\end{array}$ & $\begin{array}{l}\text { July } 2 \\
\text { July } 5 \\
\ldots \text {.do...... } \\
\text {. do..... }\end{array}$ & $\begin{array}{l}\ldots . \text { do } \\
\ldots . \text {. do do. } \\
\ldots . \text {. do. }\end{array}$ & 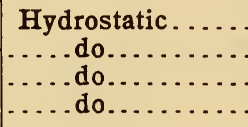 & $\begin{array}{l}25.070 \\
25.045 \\
25.046 \\
25.042\end{array}$ & $\begin{array}{l}.993365 \\
.986636 \\
.788227 \\
.791140\end{array}$ & $\begin{array}{r}.993383 \\
.986648 \\
.788267 \\
.791176\end{array}$ \\
\hline
\end{tabular}

The assembled results and their reduction to integral percentages are given in Table XLVIII. In this table also, columns 5 and 6 , are given the observed and calculated values for the effect of dissolved air on the density.

The linear equation,

$$
Y=0.3326 X
$$

in which $Y$ represents the difference in density between air-free and air-saturated mixture, $X$ the percentage of alcohol, and in which the coefficient is determined by a least square adjustment of the observed values of $Y$ is used in calculating column 6 .

It is seen that for mixtures of 95 per cent and under this equation represents the results within the limits of error of the determinations. If, however, the result for pure alcohol is considered, i. e., 0.000083 , the equation is not satisfied within 0.00005 . The results for this effect of air on the density of mixtures are given here not within any claim to their precision, but merely as a rough index of the possible effect. Further investigation by more exact methods would be of interest. 
TABLE XLVIII

Determination of Density of Alcohol-Water Mixtures, Assembled Results and Reductions

\begin{tabular}{|c|c|c|c|c|c|c|c|}
\hline \multirow{2}{*}{ Designation of mixture } & \multirow{2}{*}{$\begin{array}{c}\text { Per cent } \\
\text { alcohol } \\
\text { by weight }\end{array}$} & \multicolumn{2}{|c|}{$\begin{array}{l}\text { Mean observed } \\
\text { density at } \frac{25^{\circ}}{4}\end{array}$} & \multicolumn{2}{|c|}{$\begin{array}{c}\text { Air free } D \frac{25}{4} \\
\text { minus air satu- } \\
\text { rated } D \frac{25}{4}\end{array}$} & \multicolumn{2}{|c|}{$\begin{array}{l}\text { Reduction of air satu- } \\
\text { rated } \mathrm{D}_{25} \text { to in } \\
\text { tegral per cent }\end{array}$} \\
\hline & & Air free & $\begin{array}{c}\text { Air } \\
\text { saturated }\end{array}$ & $\begin{array}{l}\text { Obs } \\
\times 10^{6}\end{array}$ & $\begin{array}{l}\text { Cal } \\
\times 10^{6}\end{array}$ & $\mid \begin{array}{c}\text { Per cent } \\
\text { alcohol } \\
\text { by weight }\end{array}$ & $\begin{array}{l}\text { Density } \\
\text { at } \frac{25^{\circ}}{4} \mathrm{C}\end{array}$ \\
\hline $\begin{array}{rl}2 & \mathrm{D} \\
5 & \mathrm{D} \ldots . . \\
6 & \mathrm{D} \ldots . \\
10 & \mathrm{D} \ldots . . \\
15 & \mathrm{D} \ldots\end{array}$ & $\begin{array}{r}1.987 \\
4.994 \\
5.946 \\
10.008 \\
15.010\end{array}$ & $\begin{array}{c}0.988169 \\
\cdots .980431 \\
.973328\end{array}$ & $\begin{array}{r}0.993383 \\
.988176 \\
.986648 \\
.980422 \\
.973331\end{array}$ & $\begin{array}{r}-7 \\
\cdots \\
-3 \\
-3\end{array}$ & $\begin{array}{l}3 \\
5\end{array}$ & $\begin{array}{r}2 \\
5 \\
6 \\
10 \\
15\end{array}$ & $\begin{array}{r}0.993359 \\
.988166 \\
.986563 \\
.980434 \\
.973345\end{array}$ \\
\hline $\begin{array}{ll}20 & \mathrm{D} \ldots \\
25 & \mathrm{D} \ldots \\
30 & \mathrm{D} \ldots \\
35 & \mathrm{D} \ldots \\
40 & \mathrm{D} \ldots\end{array}$ & $\begin{array}{l}20.009 \\
25.088 \\
30.003 \\
35.069 \\
40.651\end{array}$ & $\begin{array}{l}.966393 \\
.958800 \\
.950685 \\
.941329 \\
.930139\end{array}$ & $\begin{array}{l}.966379 \\
.958810 \\
.950667 \\
.941326 \\
.930135\end{array}$ & $\begin{array}{r}14 \\
-10 \\
18 \\
3 \\
4\end{array}$ & $\begin{array}{r}7 \\
8 \\
10 \\
12 \\
13\end{array}$ & $\begin{array}{r}20 \\
25 \\
30 \\
-35 \\
40\end{array}$ & $\begin{array}{l}.966392 \\
.958946 \\
.950672 \\
.941459 \\
.931483\end{array}$ \\
\hline $\begin{array}{l}45 \mathrm{D} \ldots \\
50 \mathrm{D} \ldots \\
55 \mathrm{D} \ldots \\
60 \mathrm{D} \ldots \\
65 \mathrm{D} \ldots\end{array}$ & $\begin{array}{l}44.950 \\
49.998 \\
54.972 \\
60.067 \\
65.002\end{array}$ & $\begin{array}{l}.920980 \\
.909863 \\
.898576 \\
.886863 \\
.875276\end{array}$ & $\begin{array}{l}.920959 \\
.909856 \\
.898566 \\
.886835 \\
.875264\end{array}$ & $\begin{array}{r}21 \\
7 \\
10 \\
28 \\
12\end{array}$ & $\begin{array}{l}15 \\
17 \\
18 \\
20 \\
22\end{array}$ & $\begin{array}{l}45 \\
50 \\
55 \\
60 \\
65\end{array}$ & $\begin{array}{l}.920850 \\
.909852 \\
.898502 \\
.886990 \\
.875269\end{array}$ \\
\hline $\begin{array}{ll}70 & \mathrm{D} \ldots \ldots . . . \\
75 & \mathrm{D} \ldots \ldots \ldots \\
80 & \mathrm{D} \ldots \ldots \ldots \\
85 & \mathrm{D} \ldots \ldots \ldots\end{array}$ & $\begin{array}{l}70.043 \\
74.965 \\
79.946 \\
85.035\end{array}$ & $\begin{array}{l}.863337 \\
.851444 \\
.839291 \\
.826542\end{array}$ & $\begin{array}{l}.863296 \\
.851421 \\
.839247 \\
.826507\end{array}$ & $\begin{array}{l}41 \\
23 \\
44 \\
35\end{array}$ & $\begin{array}{l}23 \\
25 \\
27 \\
28\end{array}$ & $\begin{array}{l}70 \\
75 \\
80 \\
85\end{array}$ & $\begin{array}{l}.863399 \\
.851336 \\
.839114 \\
.826596\end{array}$ \\
\hline $\begin{array}{l}90 \mathrm{D} \\
90 \\
95 \\
95 \\
95 \\
95 \ldots \ldots \ldots\end{array}$ & $\begin{array}{l}90.007 \\
90.004 \\
94.818 \\
94.963\end{array}$ & $\begin{array}{l}.813623 \\
.813641 \\
.800470 \\
.800056\end{array}$ & $\begin{array}{l}.813598 \\
.813617 \\
.800434 \\
.800010\end{array}$ & $\begin{array}{l}25 \\
24 \\
36 \\
46\end{array}$ & $\begin{array}{l}30 \\
30 \\
32 \\
32\end{array}$ & $\begin{array}{l}90 \\
95\end{array}$ & $\begin{array}{r}.813622 \\
.799912\end{array}$ \\
\hline 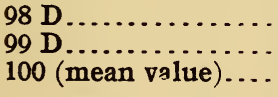 & $\begin{array}{r}97.998 \\
98.957 \\
100.000\end{array}$ & 785141 & $\begin{array}{l}.791176 \\
.788267 \\
.785058\end{array}$ & 83 & 33 & $\begin{array}{r}98 \\
99 \\
100\end{array}$ & $\begin{array}{l}.791170 \\
.788135 \\
.785058\end{array}$ \\
\hline
\end{tabular}

Table XLIX gives for every integral per cent the density at $10^{\circ}, 15^{\circ}, 20^{\circ}, 25^{\circ}, 30^{\circ}, 35^{\circ}$, and $40^{\circ} \mathrm{C}$ in terms of the density of water at $4^{\circ} \mathrm{C}$ of mixtures of ethyl alcohol and water when saturated with air. The densities at $25^{\circ}$ of integral per cents given in this table are derived from the experimental results of Table XLVIII by a method of interpolation partly graphical and partly analytical, the details of which are not of sufficient interest to be given here. The densities at $10^{\circ}, 15^{\circ}, 20^{\circ}, 30^{\circ}, 35^{\circ}$, and $40^{\circ}$ are calculated from the densities at $25^{\circ}$ by use of the equation

$$
D_{4}^{\prime}=D_{\frac{25}{4}}^{2}+\alpha(t-25)+\beta(t-25)^{2}+\gamma(t-25)^{3}
$$

The values of $\alpha, \beta$, and $\gamma$ are given in Table XXXVIIa. Page 402. 


\section{ALCOHOLOMETRIC DENSITY TABLE}

TABLE XLIX

Density of Mixtures of Ethyl Alcohol and Water $D_{4}^{t}$

\begin{tabular}{|c|c|c|c|c|c|c|c|}
\hline \multirow{2}{*}{$\begin{array}{l}\text { Per cent alcohol } \\
\text { by weight }\end{array}$} & \multicolumn{7}{|c|}{ Temperature $t$} \\
\hline & $10^{\circ} \mathrm{C}$ & $15^{\circ} \mathrm{C}$ & $20^{\circ} \mathrm{C}$ & $25^{\circ} \mathrm{C}$ & $30^{\circ} \mathrm{C}$ & $35^{\circ} \mathrm{C}$ & $40^{\circ} \mathrm{C}$ \\
\hline $\begin{array}{l}0 \\
1 \\
2 \\
3 \\
4\end{array}$ & $\begin{array}{r}0.99973 \\
.99785 \\
.99602 \\
.99426 \\
.99258\end{array}$ & $\begin{array}{r}0.99913 \\
.99725 \\
.99542 \\
.99365 \\
.99195\end{array}$ & $\begin{array}{r}0.99823 \\
.99636 \\
.99453 \\
.99275 \\
.99103\end{array}$ & $\begin{array}{r}0.99708 \\
.99520 \\
.99336 \\
.99157 \\
.98984\end{array}$ & $\begin{array}{r}0.99568 \\
.99379 \\
.99194 \\
.99014 \\
.98839\end{array}$ & $\begin{array}{r}0.99406 \\
.99217 \\
.99031 \\
.98849 \\
.98672\end{array}$ & $\begin{array}{r}0.99225 \\
.99034 \\
.98846 \\
.98663 \\
.98485\end{array}$ \\
\hline $\begin{array}{l}5 \\
6 \\
7 \\
8 \\
9\end{array}$ & $\begin{array}{r}99098 \\
.98946 \\
.98801 \\
.98660 \\
.98524\end{array}$ & $\begin{array}{r}.99032 \\
.98877 \\
.98729 \\
.98584 \\
.98442\end{array}$ & $\begin{array}{r}.98938 \\
.98780 \\
.98627 \\
.98478 \\
.98331\end{array}$ & $\begin{array}{r}.98817 \\
.98656 \\
.98500 \\
.98346 \\
.98193\end{array}$ & $\begin{array}{r}.98670 \\
.98507 \\
.98347 \\
.98189 \\
.98031\end{array}$ & $\begin{array}{r}98501 \\
.98335 \\
.98172 \\
.98009 \\
.97846\end{array}$ & $\begin{array}{r}98311 \\
.98142 \\
.97975 \\
.97808 \\
.97641\end{array}$ \\
\hline $\begin{array}{l}10 \\
11 \\
12 \\
13 \\
14\end{array}$ & $\begin{array}{r}.98393 \\
.98267 \\
.98145 \\
.98026 \\
.97911\end{array}$ & $\begin{array}{r}98304 \\
.98171 \\
.98041 \\
.97914 \\
.97790\end{array}$ & $\begin{array}{r}.98187 \\
.98047 \\
.97910 \\
.97775 \\
.97643\end{array}$ & $\begin{array}{r}98043 \\
.97897 \\
.97753 \\
.97611 \\
.97472\end{array}$ & $\begin{array}{r}.97875 \\
.97723 \\
.97573 \\
.97424 \\
.97278\end{array}$ & $\begin{array}{r}97685 \\
.97527 \\
.97371 \\
.97216 \\
.97063\end{array}$ & $\begin{array}{r}97475 \\
.97312 \\
.97150 \\
.96989 \\
.96829\end{array}$ \\
\hline $\begin{array}{l}15 \\
16 \\
17 \\
18 \\
19\end{array}$ & $\begin{array}{r}97800 \\
.97692 \\
.97583 \\
.97473 \\
.97363\end{array}$ & $\begin{array}{r}97669 \\
.97552 \\
.97433 \\
.97313 \\
.97191\end{array}$ & $\begin{array}{r}.97514 \\
.97387 \\
.97259 \\
.97129 \\
.96997\end{array}$ & $\begin{array}{r}.97334 \\
.97199 \\
.97062 \\
.96923 \\
.96782\end{array}$ & $\begin{array}{r}97133 \\
.96990 \\
.96844 \\
.96697 \\
.96547\end{array}$ & $\begin{array}{r}.96911 \\
.96760 \\
.96607 \\
.96452 \\
.96294\end{array}$ & $\begin{array}{r}.96670 \\
.96512 \\
.96352 \\
.96189 \\
.96023\end{array}$ \\
\hline $\begin{array}{l}20 \\
21 \\
22 \\
23 \\
24\end{array}$ & $\begin{array}{r}97252 \\
.97139 \\
.97024 \\
.96907 \\
.96787\end{array}$ & $\begin{array}{r}97068 \\
.96944 \\
.96818 \\
.96689 \\
.96558\end{array}$ & $\begin{array}{r}.96864 \\
.96729 \\
.96592 \\
.96453 \\
.96312\end{array}$ & $\begin{array}{r}96639 \\
.96495 \\
.96348 \\
.96199 \\
.96048\end{array}$ & $\begin{array}{r}.96395 \\
.96242 \\
.96087 \\
.95929 \\
.95769\end{array}$ & $\begin{array}{r}.96134 \\
.95973 \\
.95809 \\
.95643 \\
.95476\end{array}$ & $\begin{array}{r}.95856 \\
.95687 \\
.95516 \\
.95343 \\
.95168\end{array}$ \\
\hline $\begin{array}{l}25 \\
26 \\
27 \\
28 \\
29\end{array}$ & $\begin{array}{l}.96665 \\
.96539 \\
.96406 \\
.96268 \\
.96125\end{array}$ & $\begin{array}{r}.96424 \\
.96287 \\
.96144 \\
.95996 \\
.95844\end{array}$ & $\begin{array}{l}.96168 \\
.96020 \\
.95867 \\
.95710 \\
.95548\end{array}$ & $\begin{array}{r}.95895 \\
.95738 \\
.95576 \\
.95410 \\
.95241\end{array}$ & $\begin{array}{r}95607 \\
.95442 \\
.95272 \\
.95098 \\
.94922\end{array}$ & $\begin{array}{r}95306 \\
.95133 \\
.94955 \\
.94774 \\
.94590\end{array}$ & $\begin{array}{r}94991 \\
.94810 \\
.94625 \\
.94438 \\
.94248\end{array}$ \\
\hline $\begin{array}{l}30 \\
31 \\
32 \\
33 \\
34\end{array}$ & $\begin{array}{r}.95977 \\
.95823 \\
.95665 \\
.95502 \\
.95334\end{array}$ & $\begin{array}{r}95686 \\
.95524 \\
.95357 \\
.95186 \\
.95011\end{array}$ & $\begin{array}{r}.95382 \\
.95212 \\
.95038 \\
.94860 \\
.94679\end{array}$ & $\begin{array}{r}95067 \\
.94890 \\
.94709 \\
.94525 \\
.94337\end{array}$ & $\begin{array}{l}94741 \\
.94557 \\
.94370 \\
.94180 \\
.93986\end{array}$ & $\begin{array}{r}94403 \\
.94214 \\
.94021 \\
.93825 \\
.93626\end{array}$ & $\begin{array}{l}.94055 \\
.93860 \\
.93662 \\
.93461 \\
.93257\end{array}$ \\
\hline $\begin{array}{l}35 \\
36 \\
37 \\
38 \\
39\end{array}$ & $\begin{array}{r}.95162 \\
.94986 \\
.94805 \\
.94620 \\
.94431\end{array}$ & $\begin{array}{r}94832 \\
.94650 \\
.94464 \\
.94273 \\
.94079\end{array}$ & $\begin{array}{r}94494 \\
.94306 \\
.94114 \\
.93919 \\
.93720\end{array}$ & $\begin{array}{r}94146 \\
.93952 \\
.93756 \\
.93556 \\
.93353\end{array}$ & $\begin{array}{r}93790 \\
.93591 \\
.93390 \\
.93186 \\
.92979\end{array}$ & $\begin{array}{r}93425 \\
.93221 \\
.93016 \\
.92808 \\
.92597\end{array}$ & $\begin{array}{r}.93051 \\
.92843 \\
.92634 \\
.92422 \\
.92208\end{array}$ \\
\hline $\begin{array}{l}40 \\
41 \\
42 \\
43 \\
44\end{array}$ & $\begin{array}{r}.94238 \\
.94042 \\
.93842 \\
.93639 \\
.93433\end{array}$ & $\begin{array}{r}93882 \\
.93682 \\
.93478 \\
.93271 \\
.93062\end{array}$ & $\begin{array}{r}.93518 \\
.93314 \\
.93107 \\
.92897 \\
.92685\end{array}$ & $\begin{array}{r}93148 \\
.92940 \\
.92729 \\
.92516 \\
.92301\end{array}$ & $\begin{array}{r}92770 \\
.92558 \\
.92344 \\
.92128 \\
.91910\end{array}$ & $\begin{array}{r}92385 \\
.92170 \\
.91952 \\
.91733 \\
.91513\end{array}$ & $\begin{array}{r}.91992 \\
.91774 \\
.91554 \\
.91332 \\
.91108\end{array}$ \\
\hline $\begin{array}{l}45 \\
46 \\
47 \\
48 \\
49 \\
50\end{array}$ & $\begin{array}{r}.93226 \\
.93017 \\
.92806 \\
.92593 \\
.92379 \\
.92162\end{array}$ & $\begin{array}{r}.92852 \\
.92640 \\
.92426 \\
.92211 \\
.91995 \\
.91776\end{array}$ & $\begin{array}{r}.92472 \\
.92257 \\
.92041 \\
.91823 \\
.91604 \\
.91384\end{array}$ & $\begin{array}{r}.92085 \\
.91868 \\
.91649 \\
.91429 \\
.91208 \\
.90985\end{array}$ & $\begin{array}{r}.91692 \\
.91472 \\
.91250 \\
.91028 \\
.90805 \\
.90580\end{array}$ & $\begin{array}{l}.91291 \\
.91069 \\
.90845 \\
.90621 \\
.90396 \\
.90168\end{array}$ & $\begin{array}{l}.90884 \\
.90660 \\
.90434 \\
.90207 \\
.89979 \\
.89750\end{array}$ \\
\hline
\end{tabular}


TABLE XLIX - Continued

\begin{tabular}{|c|c|c|c|c|c|c|c|}
\hline \multirow{2}{*}{$\begin{array}{l}\text { Per cent alcohol } \\
\text { by weight }\end{array}$} & \multicolumn{7}{|c|}{ Temperature $t$} \\
\hline & $10^{\circ} \mathrm{C}$ & $15^{\circ} \mathrm{C}$ & $20^{\circ} \mathrm{C}$ & $25^{\circ} \mathrm{C}$ & $30^{\circ} \mathrm{C}$ & $35^{\circ} \mathrm{C}$ & $40^{\circ} \mathrm{C}$ \\
\hline $\begin{array}{l}50 \\
51 \\
52 \\
53 \\
54\end{array}$ & $\begin{array}{r}0.92162 \\
.91943 \\
.91723 \\
.91502 \\
.91279\end{array}$ & $\begin{array}{r}0.91776 \\
.91555 \\
.91333 \\
.91110 \\
.90885\end{array}$ & $\begin{array}{r}0.91384 \\
.91160 \\
.90936 \\
.90711 \\
.90485\end{array}$ & $\begin{array}{r}0.90985 \\
.90760 \\
.90534 \\
.90307 \\
.90079\end{array}$ & $\begin{array}{r}0.90580 \\
.90353 \\
.90125 \\
.89896 \\
.89667\end{array}$ & $\begin{array}{r}0.90168 \\
.89940 \\
.89710 \\
.89479 \\
.89248\end{array}$ & $\begin{array}{r}0.89750 \\
.89519 \\
.89288 \\
.89056 \\
.88823\end{array}$ \\
\hline $\begin{array}{l}\mathbf{5 5} \\
\mathbf{5 6} \\
\mathbf{5 7} \\
\mathbf{5 8} \\
\mathbf{5 9}\end{array}$ & $\begin{array}{r}91055 \\
.90831 \\
.90607 \\
.90381 \\
.90154\end{array}$ & $\begin{array}{r}90659 \\
.90433 \\
.90207 \\
.89980 \\
.89752\end{array}$ & $\begin{array}{l}.90258 \\
.90031 \\
.89803 \\
.89574 \\
.89344\end{array}$ & $\begin{array}{r}.89850 \\
.89621 \\
.89392 \\
.89162 \\
.88931\end{array}$ & $\begin{array}{r}.89437 \\
.89206 \\
.88975 \\
.88744 \\
.88512\end{array}$ & $\begin{array}{r}.89016 \\
.88784 \\
.88552 \\
.88319 \\
.88085\end{array}$ & $\begin{array}{r}.88589 \\
.88356 \\
.88122 \\
.87888 \\
.87650\end{array}$ \\
\hline $\begin{array}{l}60 \\
61 \\
62 \\
63 \\
64\end{array}$ & $\begin{array}{r}89927 \\
.89698 \\
.89468 \\
.89237 \\
.89006\end{array}$ & $\begin{array}{r}.89523 \\
.89293 \\
.89062 \\
.88830 \\
.88597\end{array}$ & $\begin{array}{l}.89113 \\
.88882 \\
.88650 \\
.88417 \\
.88183\end{array}$ & $\begin{array}{l}.88699 \\
.88466 \\
.88233 \\
.87998 \\
.87763\end{array}$ & $\begin{array}{l}.88278 \\
.88044 \\
.87809 \\
.87574 \\
.87337\end{array}$ & $\begin{array}{r}.87851 \\
.87615 \\
.87379 \\
.87142 \\
.86905\end{array}$ & $\begin{array}{r}.87417 \\
.87180 \\
.86943 \\
.86705 \\
.86466\end{array}$ \\
\hline $\begin{array}{l}65 \\
66 \\
67 \\
68 \\
69\end{array}$ & $\begin{array}{l}.88774 \\
.88541 \\
.88308 \\
.88074 \\
.87839\end{array}$ & $\begin{array}{l}.88364 \\
.88130 \\
.87895 \\
.87650 \\
.87424\end{array}$ & $\begin{array}{l}.87948 \\
.87713 \\
.87477 \\
.87241 \\
.87004\end{array}$ & $\begin{array}{l}.87527 \\
.87291 \\
.87054 \\
.86817 \\
.86579\end{array}$ & $\begin{array}{l}.87100 \\
.86863 \\
.86625 \\
.86387 \\
.86148\end{array}$ & $\begin{array}{l}.86667 \\
.86429 \\
.86190 \\
.85950 \\
.85710\end{array}$ & $\begin{array}{r}.86227 \\
.85987 \\
.85747 \\
.85507 \\
.85266\end{array}$ \\
\hline $\begin{array}{l}70 \\
71 \\
72 \\
73 \\
74\end{array}$ & $\begin{array}{l}.87602 \\
.87365 \\
.87127 \\
.86888 \\
.86648\end{array}$ & $\begin{array}{l}.87187 \\
.86949 \\
.86710 \\
.86470 \\
.86229\end{array}$ & $\begin{array}{l}.86766 \\
.86527 \\
.86287 \\
.86047 \\
.85806\end{array}$ & $\begin{array}{r}.86340 \\
.86100 \\
.85859 \\
.85618 \\
.85376\end{array}$ & $\begin{array}{r}.85908 \\
.85667 \\
.85426 \\
.85184 \\
.84941\end{array}$ & $\begin{array}{l}.85470 \\
.85228 \\
.84986 \\
.84743 \\
.84500\end{array}$ & $\begin{array}{r}.85025 \\
.84783 \\
.84540 \\
.84297 \\
.84053\end{array}$ \\
\hline $\begin{array}{l}75 \\
76 \\
77 \\
78 \\
79\end{array}$ & $\begin{array}{l}.86408 \\
.86168 \\
.85927 \\
.85685 \\
.85442\end{array}$ & $\begin{array}{l}.85988 \\
.85747 \\
.85505 \\
.85262 \\
.85018\end{array}$ & $\begin{array}{l}.85564 \\
.85322 \\
.85079 \\
.84835 \\
.84590\end{array}$ & $\begin{array}{l}.85134 \\
.84891 \\
.84647 \\
.84403 \\
.84158\end{array}$ & $\begin{array}{l}.84698 \\
.84455 \\
.84211 \\
.83966 \\
.83720\end{array}$ & $\begin{array}{l}.84257 \\
.84013 \\
.83768 \\
.83523 \\
.83277\end{array}$ & $\begin{array}{r}.83809 \\
.83564 \\
.83319 \\
.83074 \\
.82827\end{array}$ \\
\hline $\begin{array}{l}80 \\
81 \\
82 \\
83 \\
84\end{array}$ & $\begin{array}{l}.85197 \\
.84950 \\
.84702 \\
.84453 \\
.84203\end{array}$ & $\begin{array}{l}.84772 \\
.84525 \\
.84277 \\
.84028 \\
.83777\end{array}$ & $\begin{array}{l}.84344 \\
.84096 \\
.83848 \\
.83599 \\
.83348\end{array}$ & $\begin{array}{r}.83911 \\
.83664 \\
.83415 \\
.83164 \\
.82913\end{array}$ & $\begin{array}{l}.83473 \\
.83224 \\
.82974 \\
.82724 \\
.82473\end{array}$ & $\begin{array}{r}.83029 \\
.82780 \\
.82530 \\
.82279 \\
.82027\end{array}$ & $\begin{array}{r}.82578 \\
.82329 \\
.82079 \\
.81828 \\
.81576\end{array}$ \\
\hline $\begin{array}{l}85 \\
86 \\
87 \\
88 \\
89\end{array}$ & $\begin{array}{l}.83951 \\
.83697 \\
.83441 \\
.83181 \\
.82919\end{array}$ & $\begin{array}{l}.83525 \\
.83271 \\
.83014 \\
.82754 \\
.82492\end{array}$ & $\begin{array}{l}.83095 \\
.82840 \\
.82583 \\
.82323 \\
.82062\end{array}$ & $\begin{array}{l}.82660 \\
.82405 \\
.82148 \\
.81888 \\
.81626\end{array}$ & $\begin{array}{r}.82220 \\
.81965 \\
.81708 \\
.81448 \\
.81186\end{array}$ & $\begin{array}{l}.81774 \\
.81519 \\
.81262 \\
.81003 \\
.80742\end{array}$ & $\begin{array}{r}.81322 \\
.81067 \\
.80811 \\
.80552 \\
.80291\end{array}$ \\
\hline $\begin{array}{l}90 \\
91 \\
92 \\
93 \\
94\end{array}$ & $\begin{array}{r}.82654 \\
.82386 \\
.82114 \\
.81839 \\
.81561\end{array}$ & $\begin{array}{l}.82227 \\
.81959 \\
.81688 \\
.81413 \\
.81134\end{array}$ & $\begin{array}{l}.81797 \\
.81529 \\
.81257 \\
.80983 \\
.80705\end{array}$ & $\begin{array}{r}.81362 \\
.81094 \\
.80823 \\
.80549 \\
.80272\end{array}$ & $\begin{array}{r}.80922 \\
.80655 \\
.80384 \\
.80111 \\
.79835\end{array}$ & $\begin{array}{r}.80478 \\
.80211 \\
.79941 \\
.79669 \\
.79393\end{array}$ & $\begin{array}{r}.80028 \\
.79761 \\
.79491 \\
.79220 \\
.78947\end{array}$ \\
\hline $\begin{array}{r}95 \\
96 \\
97 \\
98 \\
99 \\
100\end{array}$ & $\begin{array}{l}.81278 \\
.80991 \\
.80698 \\
.80399 \\
.80094 \\
.79784\end{array}$ & $\begin{array}{l}.80852 \\
.80566 \\
.80274 \\
.79975 \\
.79670 \\
.79360\end{array}$ & $\begin{array}{l}.80424 \\
.80138 \\
.79846 \\
.79547 \\
.79243 \\
.78934\end{array}$ & $\begin{array}{l}.79991 \\
.79706 \\
.79415 \\
.79117 \\
.78814 \\
.78506\end{array}$ & $\begin{array}{l}.79555 \\
.79271 \\
.78981 \\
.78684 \\
.78382 \\
.78075\end{array}$ & $\begin{array}{l}.79114 \\
.78831 \\
.78542 \\
.78247 \\
.77946 \\
.77641\end{array}$ & $\begin{array}{r}.78670 \\
.78388 \\
.78100 \\
.77806 \\
.77507 \\
.77203\end{array}$ \\
\hline
\end{tabular}


TABLE L

Comparison of Densities of Various Per Cents Alcohol by Weight

\begin{tabular}{|c|c|c|c|c|c|c|c|c|c|c|c|}
\hline \multirow{3}{*}{$\begin{array}{c}\text { Per } \\
\text { cent } \\
\text { alcohol } \\
\text { by } \\
\text { weight }\end{array}$} & \multirow[b]{2}{*}{$\begin{array}{l}\text { Bureau } \\
\text { of Stand- } \\
\text { ards }^{1376} \\
1910\end{array}$} & \multicolumn{6}{|c|}{ Mendelêeff's values recalculated by- } & \multirow[b]{2}{*}{$\begin{array}{c}\text { Mende-- } \\
\text { léeff } 207,241 \\
1865 f\end{array}$} & \multirow[b]{2}{*}{$\begin{array}{l}\text { B. S. } \\
1910- \\
\text { Mend. }\end{array}$} & \multirow[b]{2}{*}{$\begin{array}{l}\text { Kreit- } \\
\text { ling } \\
1892 g\end{array}$} & \multirow[b]{2}{*}{$\begin{array}{l}\text { B.S. S. } \\
1910- \\
\text { Kreit. }\end{array}$} \\
\hline & & $\begin{array}{c}\text { Bureau } \\
\text { of Stand- } \\
\text { ards } 1216 \\
1909\end{array}$ & $\begin{array}{l}\text { B. S. } \\
1910- \\
\text { B. S. } \\
1909\end{array}$ & $\begin{array}{c}\text { E. W. } \\
\text { Mor- } \\
\text { leyy005 } \\
1904\end{array}$ & $\begin{array}{c}\text { B. S. } \\
1910- \\
\text { Mor- } \\
\text { ley }\end{array}$ & $\begin{array}{c}\text { K. } \\
\text { Normal- } \\
\text { Eichungs } \\
\text { Komm.685 } \\
1893 e\end{array}$ & $\begin{array}{l}\text { B. S. } \\
1910- \\
\text { K. N. } \\
\text { E. K. }\end{array}$ & & & & \\
\hline & $D \frac{20^{\circ}}{4^{\circ}} \mathrm{C}$ & $\mathrm{D} \frac{20^{\circ}}{4^{\circ}} \mathrm{C}$ & $\begin{array}{l}\text { Units } \\
\text { of } \\
\text { fifth } \\
\text { place }\end{array}$ & $\mathrm{D} \frac{20^{\circ}}{4^{\circ}} \mathrm{C}$ & $\begin{array}{l}\text { Units } \\
\text { of } \\
\text { fifth } \\
\text { place }\end{array}$ & $D^{2 \frac{20}{4^{\circ}}} \mathrm{C}$ & $\begin{array}{l}\text { Units } \\
\text { of } \\
\text { fifth } \\
\text { place }\end{array}$ & $\mathrm{D} \frac{20^{\circ}}{4^{\circ}} \mathrm{C}$ & $\begin{array}{c}\text { Units } \\
\text { of } \\
\text { fifth } \\
\text { place }\end{array}$ & $\mathrm{D} \frac{20^{\circ}}{4^{\circ}} \mathrm{C}$ & $\begin{array}{l}\text { Units } \\
\text { of } \\
\text { fifth } \\
\text { place }\end{array}$ \\
\hline 0 & 99823 & 99824 & -1 & 99824 & -1 & 99824 & -1 & 99831 & -8 & 99823 & 0 \\
\hline 5 & 98939 & 98936 & +3 & 98927 & +12 & 98948 & -9 & 98945 & -6 & 98941 & -2 \\
\hline 10 & 98187 & 98185 & +2 & 98189 & -2 & 98197 & -10 & 98195 & -8 & 98194 & -7 \\
\hline 15 & 97514 & 97522 & -8 & 97519 & -5 & 97533 & -19 & 97527 & -13 & 97531 & -17 \\
\hline 20 & 96864 & 96870 & -6 & 96872 & -8 & 96877 & -13 & 96877 & -13 & 96877 & -13 \\
\hline 25 & 96168 & 96171 & -3 & 96175 & -7 & 96171 & -3 & 96185 & -17 & 96175 & -7 \\
\hline 30 & 95382 & 95385 & -3 & 95387 & -5 & 95381 & +1 & 95403 & -21 & 95380 & +2 \\
\hline 35 & 94494 & 94499 & -5 & 94506 & -12 & 94496 & -2 & 94514 & -20 & 94503 & -9 \\
\hline 40 & 93519 & 93524 & -5 & 93525 & -6 & 93523 & -4 & 93511 & +8 & 93527 & -8 \\
\hline 45 & 92472 & 92480 & -8 & 92483 & -11 & 92484 & -12 & 92493 & -21 & 92485 & -13 \\
\hline 50 & 91384 & 91386 & -2 & 91386 & -2 & 91393 & -9 & 91400 & -16 & 91392 & -8 \\
\hline 55 & 90258 & 90262 & -4 & 90263 & -5 & 90265 & -7 & 90275 & -17 & 90263 & -5 \\
\hline 60 & 89114 & 89115 & -1 & 89115 & -1 & 89115 & -1 & 89129 & -15 & 89114 & 0 \\
\hline 65 & 87948 & 87950 & -2 & 87950 & -2 & 87946 & +2 & 87961 & -13 & 87948 & 0 \\
\hline 70 & 86766 & 86770 & -4 & 86769 & -3 & 86762 & +4 & 86781 & -15 & 86767 & -1 \\
\hline 75 & 85564 & 85570 & -6 & 85569 & -5 & 85562 & +2 & 85580 & -16 & 85567 & -3 \\
\hline 80 & 84344 & 84349 & -5 & 84348 & -4 & 84339 & +5 & 84366 & -22 & 84347 & -3 \\
\hline 85 & 83095 & 83097 & -2 & 83097 & -2 & 83091 & +4 & 83115 & -20 & 83099 & -4 \\
\hline 90 & 81797 & 81795 & +2 & 81794 & +3 & 81795 & +2 & 81801 & -4 & 81801 & -4 \\
\hline 95 & 80423 & 80417 & +6 & 80421 & +2 & 80424 & -1 & 80433 & -10 & 80424 & -1 \\
\hline 100 & 78934 & 78933 & +1 & 78932 & +2 & 78939 & -5 & 78945 & -11 & 78930 & +4 \\
\hline
\end{tabular}

e Recalculated from Mendeléeff's values of $\mathrm{D}_{15}^{20^{\circ}} \mathrm{C}$, given in Landolt and Börnstein (1905).

$f$ Mendeléeff's ${ }^{207,241}$ uncorrected valúes.

$g$ Recalculated from Kreitling's ${ }^{646}$ values of $\mathrm{D} \frac{20^{\circ}}{15^{\circ}} \mathrm{C}$. 
TABLE LI

Comparison of Densities of Various Per Cents Alcohol by Volume at $60^{\circ} \mathrm{F}$ $(15.56 \mathrm{C})$

\begin{tabular}{|c|c|c|c|c|c|c|c|c|c|c|c|}
\hline \multirow{3}{*}{$\begin{array}{c}\text { Per } \\
\text { cent } \\
\text { alco- } \\
\text { hol by } \\
\text { vol- } \\
\text { ume } \\
\text { at } \\
60^{\circ} \mathrm{F}\end{array}$} & \multirow{2}{*}{$\begin{array}{c}\text { Bureau } \\
\text { of Stand- } \\
\text { ards }^{1376} \\
1910\end{array}$} & \multicolumn{4}{|c|}{$\begin{array}{c}\text { Mendeléeff's values recalculated } \\
\text { by- }\end{array}$} & \multirow{2}{*}{$\begin{array}{l}\text { McCul- } \\
\text { loch119h }\end{array}$} & \multirow{2}{*}{$\begin{array}{l}\text { B. S. } \\
1910- \\
\text { McC. }\end{array}$} & \multirow[b]{2}{*}{ Squibb ${ }^{433} i$} & \multirow{2}{*}{$\begin{array}{c}\text { B. S. } \\
1910- \\
\text { Squibb }\end{array}$} & \multirow{2}{*}{$\begin{array}{l}\text { Gilpin, }{ }^{8} \\
\text { Drink- } \\
\text { water, }{ }^{102} \\
\text { and } \\
\text { Squibb } \\
\text { Sa3 } i\end{array}$} & \multirow{2}{*}{$\begin{array}{c}\text { B. S. } \\
1910- \\
\text { G., } \\
\text { D., } \\
\text { and S }\end{array}$} \\
\hline & & $\begin{array}{c}\text { Bureau } \\
\text { of Stand- } \\
\text { ards } 1216 \\
1909\end{array}$ & $\begin{array}{l}\text { B. S. } \\
1910- \\
\text { B. S. } \\
1909\end{array}$ & $\begin{array}{c}\text { K. } \\
\text { Normal- } \\
\text { Eichungs } \\
\text { Komm. }\end{array}$ & $\begin{array}{l}\text { B. S. } \\
1910- \\
\text { K. N. } \\
\text { E. K. }\end{array}$ & & & & & & \\
\hline & $\mathrm{D} \frac{60^{\circ}}{60^{\circ}} \mathrm{F}$ & $\mathrm{D} \frac{60^{\circ}}{60^{\circ}} \mathrm{F}$ & $\begin{array}{c}\text { Units } \\
\text { of } \\
\text { fifth } \\
\text { place }\end{array}$ & $\mathrm{D} \frac{60^{\circ}}{60^{\circ}} \mathbf{F}$ & $\begin{array}{c}\text { Units } \\
\text { of } \\
\text { fifth } \\
\text { place }\end{array}$ & $\mathrm{D} \frac{60^{\circ}}{60^{\circ}} \mathrm{F}$ & $\begin{array}{c}\text { Units } \\
\text { of } \\
\text { fifth } \\
\text { place }\end{array}$ & $\mathrm{D} \frac{60^{\circ}}{60^{\circ}} \mathrm{F}$ & $\begin{array}{c}\text { Units } \\
\text { of } \\
\text { fifth } \\
\text { place }\end{array}$ & $\mathrm{D} \frac{60^{\circ}}{60^{\circ}} \mathrm{F}$ & $\begin{array}{l}\text { Units } \\
\text { of } \\
\text { fifth } \\
\text { place }\end{array}$ \\
\hline 0 & 1.00000 & 1.00000 & 0 & 1.00000 & 0 & 1.00000 & 0 & 1.0000 & 0 & 1.00000 & 0 \\
\hline 5 & .99282 & .99283 & -1 & .99279 & +3 & .99289 & -7 & .9930 & -18 & .99281 & +1 \\
\hline 10 & .98659 & .98658 & +1 & .98657 & +2 & .98663 & -4 & .9869 & -31 & .98660 & -1 \\
\hline 15 & .98104 & .98112 & -8 & .98114 & -10 & .98114 & -10 & .9815 & -46 & .98114 & -10 \\
\hline 20 & .97595 & .97607 & -12 & .97608 & -13 & .97600 & -5 & .9760 & -5 & .97608 & -13 \\
\hline 25 & .97086 & .97096 & -10 & .97097 & -11 & .97087 & -1 & .9709 & -4 & .97097 & -11 \\
\hline 30 & .96535 & .96540 & -5 & .96541 & -6 & .96541 & -6 & .9652 & +15 & .96541 & -6 \\
\hline 35 & .95910 & .95909 & +1 & .95910 & 0 & .95915 & -5 & .9593 & -20 & .95910 & 0 \\
\hline 40 & .95179 & .95184 & -5 & .95185 & -6 & .95192 & -13 & .9519 & -11 & .95185 & -6 \\
\hline 45 & .94350 & .94360 & -10 & .94364 & -14 & .94359 & -9 & .9434 & +10 & .94364 & -14 \\
\hline 50 & .93428 & .93440 & -12 & .93445 & -17 & .93437 & -9 & .9343 & -2 & .93443 & -15 \\
\hline 55 & .92419 & .92435 & -16 & .92439 & -20 & .92427 & -8 & .9242 & -1 & & \\
\hline 60 & .91343 & .91356 & -13 & .91358 & -15 & .91346 & -3 & .9135 & -7 & & \\
\hline 65 & .90202 & .90210 & -8 & .90214 & -12 & .90211 & -9 & .9025 & -48 & & \\
\hline 70 & .88999 & .89004 & -5 & .89010 & -11 & .89003 & -4 & .8900 & -1 & & \\
\hline 75 & .87729 & .87734 & -5 & .87740 & -11 & .87730 & -1 & .8769 & +39 & & \\
\hline 80 & .86381 & .86389 & -8 & .86395 & -14 & .86384 & -3 & .8639 & -9 & & \\
\hline 85 & .84942 & .84955 & -13 & .84961 & -19 & .84950 & -8 & .8496 & -18 & & \\
\hline 90 & .83381 & .83394 & -13 & .83400 & -19 & .83385 & -4 & .8340 & -19 & & \\
\hline 95 & .81604 & .81611 & -7 & .81616 & -12 & .81598 & +6 & .8164 & -36 & & \\
\hline 100 & .79388 & .79387 & +1 & . 79391 & -3 & .79461 & -73 & .7946 & -72 & & \\
\hline
\end{tabular}

$h$ From the table given in Gauger's Manual.215,1311.

$i$ Bulletin No. 107 (Revised) Bureau of Chemistry. 1265. 


\section{REVIEW OF RESULTS}

A comparison between the results of this investigation and those of other experimenters is shown in Tables L, and LI. The results compared are the basis of several of the most important alcoholometric tables in general use at the present time. In order to render the different tables directly comparable, they have, as far as possible, been reduced to the same temperature basis.

In regard to the accuracy of Mendeléeff's results, reference to his publication ${ }^{241}$ of 1869 and examination of the tables of densities which he calculated by least square adjustment of the experimental data, shows differences between the observed and calculated results of several units of the fourth decimal place. Whether these discrepancies are attributed to experimental error or arise from defective adjustment, they furnish an indication of the magnitude of unexplained discordance. The adjusted values agree slightly better than the observed with the results presented here and have been used for comparison.

Explanation of the outstanding differences shown in the preceding comparison tables will not here be undertaken further than to suggest the possibility that a greater degree of refinement in apparatus and experimental conditions with regard to temperature control and measurement in particular have in the present work enabled the attainment of higher precision.

Taking into account all sources of error it would be difficult to account for any error in Table XIIX greater than .00004; however, the desirability of further experimental work to ascertain the accuracy with which the fundamental determinations can be repeated by another observer is suggested.

In conclusion, the author acknowledges indebtedness to Mr. H. W. Bearce for valuable assistance in the observations and calculations involved in the determinations.

Washington, August I, I9ro 


\title{
PART 4
}

\section{DENSITY OF ETHYL ALCOHOL AND OF ITS MIXTURES WITH WATER. (A CONFIRMATORY SERIES)}

\author{
By H. W. Bearce
}

During December, I910, and January, I9I I, the work on ethyl alcohol and its mixtures with water was continued. A second and independent series of mixtures were prepared and their densities measured at $15^{\circ}$ and $25^{\circ}$ for the purpose of determining the reproducibility of the results already obtained. By making the determinations at both $15^{\circ}$ and $25^{\circ}$ it was possible to verify, at the same time, the densities at $25^{\circ}$ and the rate of change of density between $15^{\circ}$ and $25^{\circ}$.

\section{DESCRIPTION OF EXPERIMENTAL WORK}

\section{MATERIAL, APPARATUS, AND METHODS}

The alcohol used for making the mixtures was from two new distillations of the same original material as that used in the first series.

A mixture of fractions 4,6 , and 8 of Experiment XIV (see p. 366, pt. I) was used for making the mixtures designated in Table LIV as Io E, $20 \mathrm{E}, 30 \mathrm{G}, 40 \mathrm{E}, 60 \mathrm{E}, 70 \mathrm{E}, 80 \mathrm{E}$, and $90 \mathrm{E}$, while for making those mixtures designated as $20 \mathrm{G}, 30 \mathrm{H}, 50 \mathrm{E}$, and $70 \mathrm{~F}$ the mixed fractions for Experiment $\mathrm{XV}$ were used. The alcohol used for making the mixtures was in each case, immediately after distillation, placed in a glass receptacle closed by closely fitting ground joints. This receptacle was provided with a burette attachment through which the alcohol was drawn off as required for making the mixtures. Only air that had been passed through drying tubes containing calcium chloride and phosphorous pentoxide was allowed to come in contact with the alcohol.

The balances, weights, thermometers, sinker, and apparatus for controlling the temperature were those already described 
All density determinations were made by the method of hydrostatic weighing. The methods of procedure that have been described in detail in parts 2 and 3 of this paper were, as far as possible, followed in part 4 .

During this series of measurements ice-point readings of the thermometers were not taken after each temperature, but were taken at intervals sufficiently short to have shown any considerable change had it occurred. It is believed that the mean of the extended series of ice-point readings available from earlier work with the same thermometers, at the same temperatures, gives as consistent and as reliable results as could be obtained by individual readings.

For making the mixtures an ordinary graduated, stoppered flask was used instead of the special mixing bulb described in part 3 . All mixtures were made with twice-distilled, air-free water, and to prevent expulsion of air bubbles at the higher temperature the mixtures were freed from excess of dissolved air by evacuating to about I cm of mercury and thoroughly shaking. At the time of determination they were probably in an approximately airsaturated condition.

In the following tabulated results no determinations have been omitted except those of two mixtures which were spoiled in the process of making and one other in which the temperature conditions were unsatisfactory. A comparison of these results with those given in part 3 of this paper is shown in Table LV, page 435 . 


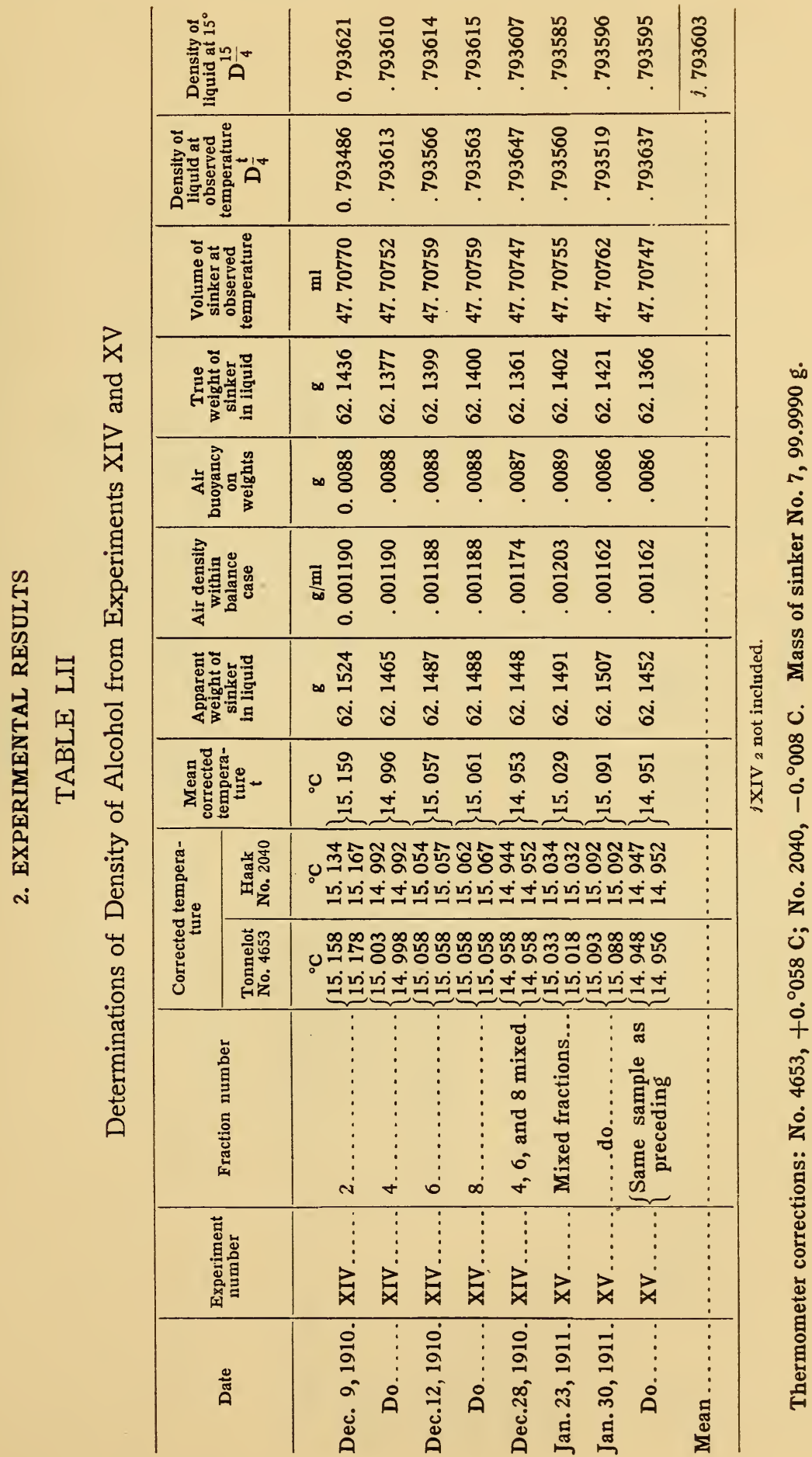




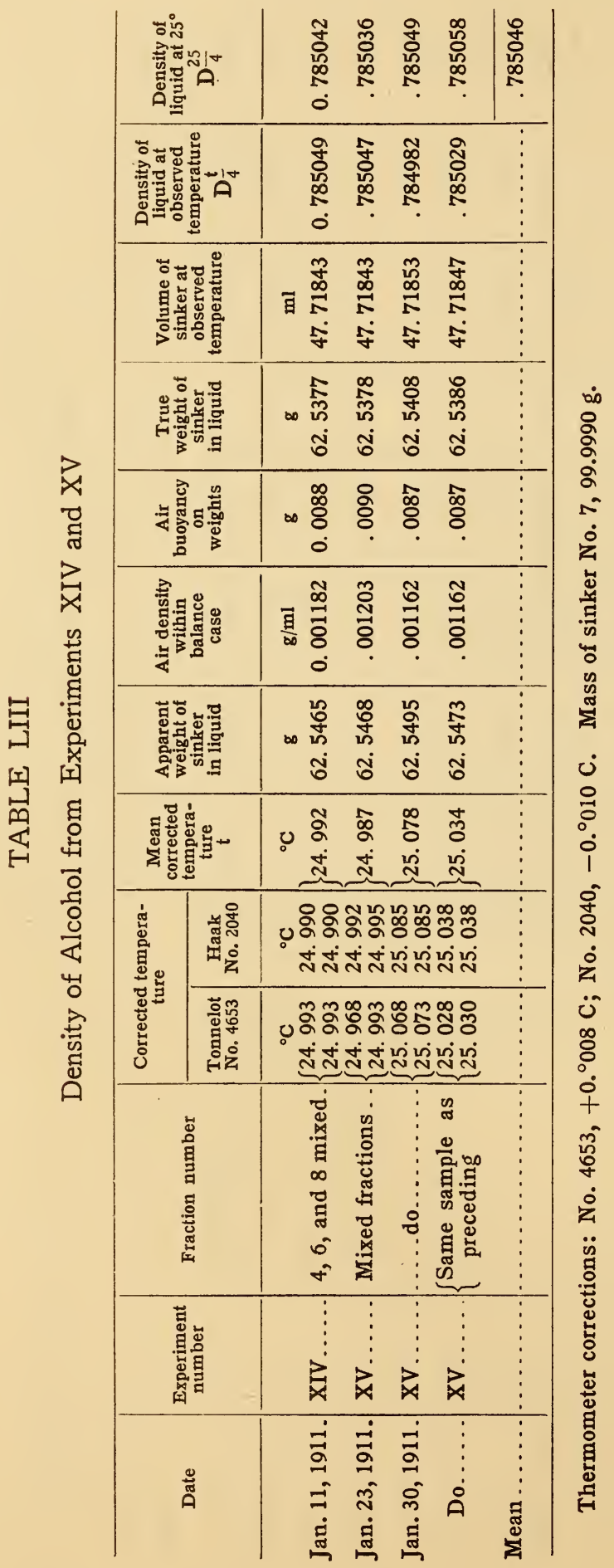




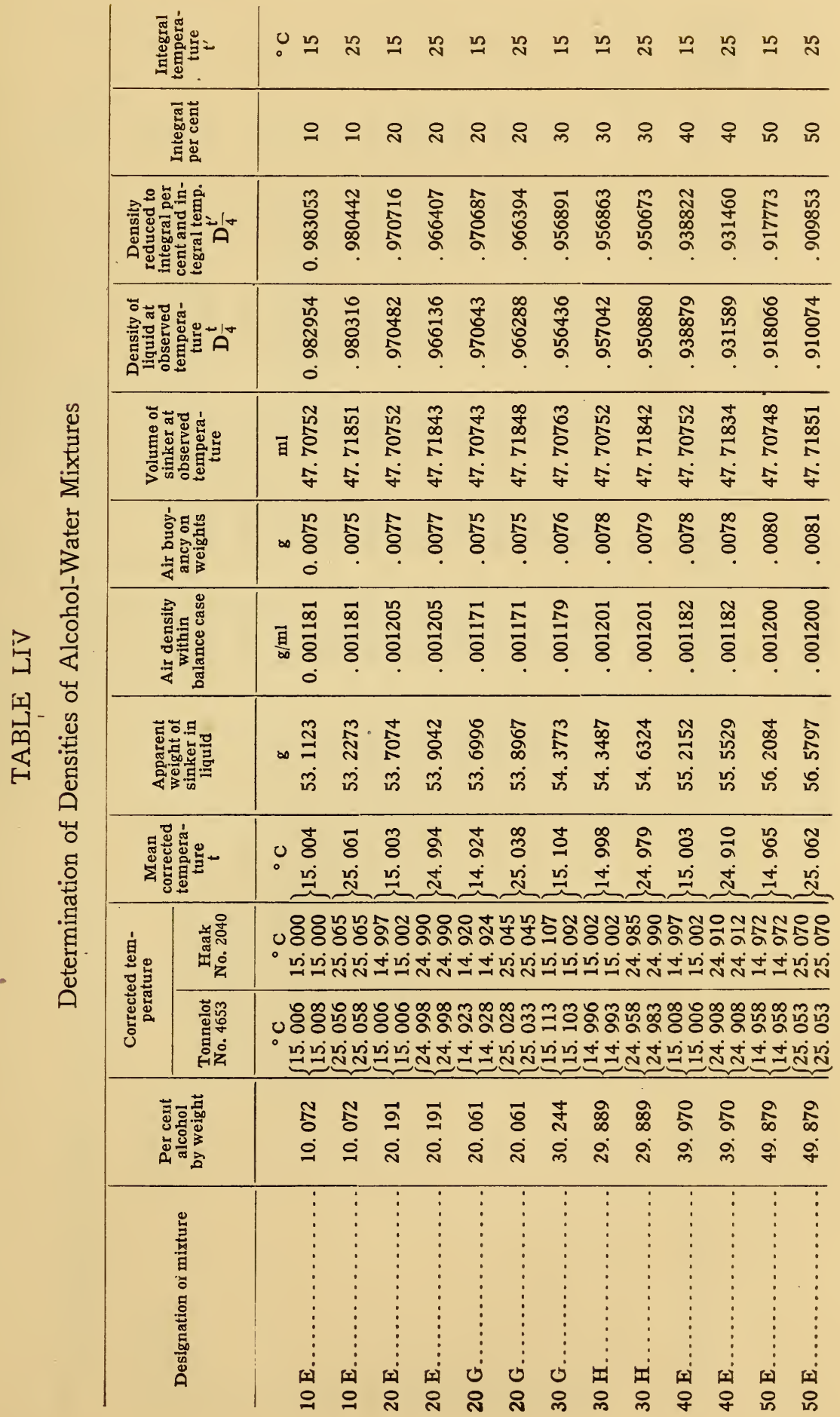




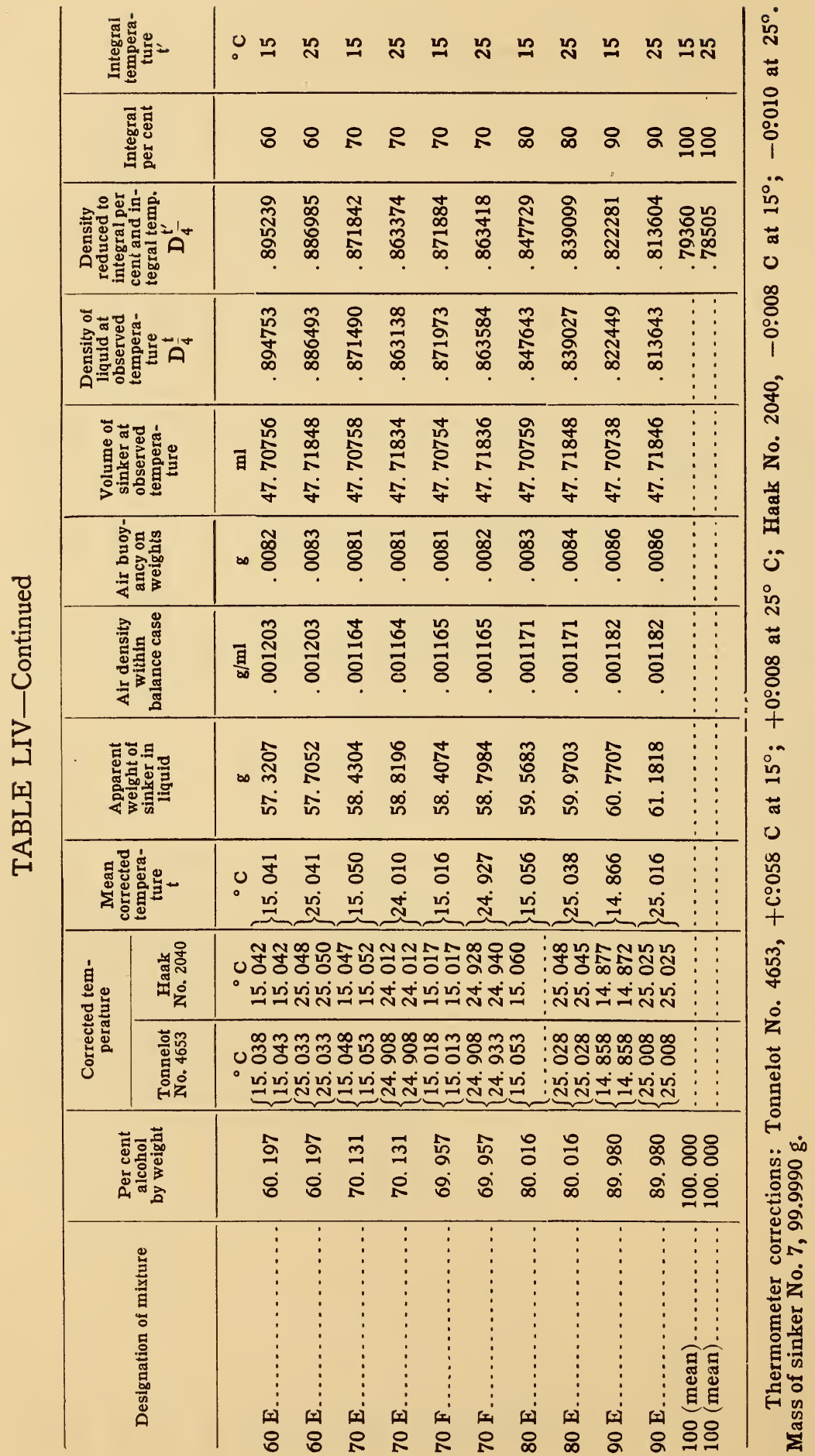


TABLE LV

A Comparison of Results

\begin{tabular}{|c|c|c|c|c|c|c|}
\hline $\begin{array}{l}\text { Per cent } \\
\text { alcohol } \\
\text { by weight }\end{array}$ & $\begin{array}{l}\mathrm{D} \frac{15^{\circ}}{4^{\circ}} \mathrm{C} \\
\text { Osborne }\end{array}$ & $\begin{array}{l}D \frac{15^{\circ}}{4^{\circ}} \mathrm{C} \\
\text { Bearce }\end{array}$ & $\begin{array}{c}(\mathrm{O}-\mathrm{B}) \\
\text { difference } \\
\times 10^{5}\end{array}$ & $\begin{array}{l}D^{25^{\circ}} \\
\text { Osborne }\end{array}$ & $\begin{array}{l}\mathrm{D} \frac{25^{\circ}}{4^{\circ}} \mathrm{C} \\
\text { Bearce }\end{array}$ & $\begin{array}{c}(\mathbf{O}-\mathbf{B}) \\
\text { difference } \\
\times 10^{5}\end{array}$ \\
\hline $\begin{array}{r}0 \\
10 \\
20 \\
30 \\
40 \\
50 \\
60 \\
70 \\
80 \\
90 \\
100\end{array}$ & $\begin{array}{r}0.99913 \\
.98304 \\
.97069 \\
.95686 \\
.93883 \\
.91776 \\
.89523 \\
.87187 \\
.84772 \\
.82228 \\
.79360\end{array}$ & $\begin{array}{r}0.99913 \\
.98305 \\
.97070 \\
.95688 \\
.93882 \\
.91777 \\
.89524 \\
.87186 \\
.84773 \\
.82228 \\
.79360\end{array}$ & $\begin{array}{r}-1 \\
-1 \\
-2 \\
+1 \\
-1 \\
-1 \\
+1 \\
-1 \\
0 \\
0\end{array}$ & $\begin{array}{r}0.99708 \\
.98043 \\
.96639 \\
.95067 \\
.93148 \\
.90985 \\
.88699 \\
.86340 \\
.83911 \\
.81362 \\
.78506\end{array}$ & $\begin{array}{r}0.99708 \\
.98044 \\
.96640 \\
.95067 \\
.93146 \\
.90985 \\
.88698 \\
.86340 \\
.83910 \\
.81360 \\
.78505\end{array}$ & $\begin{array}{r}-1 \\
-1 \\
0 \\
+2 \\
0 \\
+1 \\
0 \\
+1 \\
+2 \\
+1\end{array}$ \\
\hline
\end{tabular}

$7739^{\circ}-\mathrm{I} 3-8$ 


\title{
PART 5 \\ BIBLIOGRAPHY
}

\author{
By E. C. McKelvy
}

\section{BIBLIOGRAPHY OF THE LITERATURE ON ALCOHOL AND ALCOHOLOMETRY}

This bibliography has been compiled to meet the need of workers in the field of alcoholometry and all those interested in the physical properties and purification of the alcohols. It is hoped that the field has been covered reasonably completely. Especial attention has been given to completeness with respect to the purification and physical properties of ethyl alcohol and the points discussed in the present paper. It is considered that practically every physical property has a possible application in alcoholometry and in the tests that go to show the existence of a chemically pure substance. The three factors most important in the choosing of a physical constant for determining the composition of alcohol-water mixtures, or any other binary mixture, are, first, sensitiveness, determined by the rate of change of the given constant with change in composition; second, accuracy of the determination of the physical constant; third, ease and range of applicability. The first, though depending somewhat on the second and third factors, is more or less fixed, being essentially dependent on the nature of the components. The second and third factors depend largely on the state of experimental physical science, and consequently change as science progresses. The study of the relation between physical constants and composition in the binary mixture ethyl alcohol-water, in order to get light on the first factor above mentioned, has been taken up thoroughly for only a few constants. The density and thermal expansion have been studied most extensively because of their early application to alcoholometry. In the determination of the physical constants of pure ethyl alcohol, as a rule, little attention has been paid to 436 
the possible water content and its effect. A critical analysis of the results already obtained on other constants besides those above mentioned and the redetermination of many of them are contemplated at this Bureau. The compilation of this bibliography is a preliminary step in that direction.

No attempt has been made to cover the more technological parts of the subject or the chemistry of alcoholic fermentations. Acknowledgment is made of the valuable help given by Dr. W. Bein, of the "Kaiserliche Normal-Eichungs Kommission," Berlin, in the preparation of this part of the work.

\section{REFERENCES IN CHRONOLOGICAL ORDER}

Each reference is made up, where the complete information is available, of the name of author or authors, the journal in which presented, the extent of the article, and the year in which published except where the chronological arrangement shows that information. The references of special interest with respect to the work of this paper are provided with an asterisk. Special parts of extensive articles are indicated by the page number. Notices of the abstracts are also included in the majority of cases.

The references are arranged chronologically by years and alphabetically within the year. They are numbered consecutively. The accompanying numbers in italics refer to the decimal classification of the subject matter and show the subjects treated of in the article in a much more complete manner than the title.

The abbreviations are, with few exceptions, those used by Chemical Abstracts, published by the American Chemical Society. C. B. has been used to indicate "Chemisches Zentralblatt" and J. B. the "Jahresberichte über die Fortschritte der Chemie und verwandter Teile anderer Wissenschaften."

\section{CHRONOLOGICAL LIST OF REFERENCES}

1. Lullus, Raymond (18th Century). Preparation of Concentrated Alcohol "Ultima consolatio corporis humani." (See H. Lescoeur (I896)): 631142 .

2. Brisson. Mém. acad. franc., 433: 2222, 22221, 73.

3. Hagen, C. G. Diss. Regiomontanus, Dissertatio de natura partis inflammabilis spiritus vini: I3. 
*4. Blagden, C. Phil. Trans., 80, 32I-45: 2222, 2222I, 3222, 3222I, 74.

\section{2}

*5. Blagden, C. Phil. Trans., 82, 425-55; Ann. chim. phys. (I), 23, I39 (I 797): 2222, $22221,3222,32221$. 6. Ramsden, J. Ann. chim. phys. (1), 13, 243-79; Gilb. Ann., 1, 162 (1799): 75.

\section{3}

7. Richter, J. B. Anfangsgründe der Stöchyometrie oder Messkunst chymischer Elemente. Diitter Theil. Breslau und Hirschberg bei Johann Friedrich Korn dem Aelteren, 263: 63II43.

\section{4}

*8. Gilpin, Geo. Phil. Trans., 84, 275-382; Gren. Neues Jahrbuch, 2, 365 (1795); Ann. chim. phys. (I) 23, $\times 39(1797): 73$.

\section{5}

9. Richter, J. B. Ueber die neueren Gegenstände der Chymie. Breslau, Hirschberg und Lissa in Südpreussen bei Johann Friedrich Korn dem Aelteren. V Heft, p. 8, 72; VIII Heft, p. 67 (1797): 2222, 631543.

\section{6}

*10. Lowitz, T. Crelle's Chem. Ann., 1, 195-204; Nova Acta. Petropolitanae, 11, 299 (1798): 2222, 63rI42, 631146.

*11. Richter, D. Crellc's Chem. Ann., 2, 211: 2222, 63 II43.

12. Schmidt, G. G. Neues Gren. J., 3, r18-33; Gilb. Ann., 17, 485-7I (1804); 26, 368 (1807): 721.

\section{2}

13. Fletscher, J. Nicholson's J., 2, 276-8I; Gilb. Ann., 38, 432-4I (I8II); 49, I9I (I8I5): 721.

\section{3}

14. Atkins, G. Ann. chim. phys. (1), 48, 5-28: 75 .

*15. Atkins, G. and Coy. Phil. Mag. Tilloch., 16, 26-33, 205-12, 305-12; 17, 204-10, 329-4I (1804): 7.

16. Speer, T. C. Phil. Mag., 14, 151: 722 .

\section{7}

17. Saussure, N. T. de. Ann. chim. phys. (I), 62, 225-41; Gilb. Ann., 29, 118-34, 268 (1808); Ann. chim, phys. (I), 89, 273-305 (I8I4): 2222, 63 II 43 .

1808

18. Atkins, G. Phil. Mag. Tilloch., 31, 254-8: 721 .

1809

19. Sömmerring, S. T. von. Denkschr. Akad. München (I8II-I2), 273-92; Gilb. Ann., 61, I04-Io (I8I9). 3227.

\section{1}

*20. Tralles, J. G. Secret. d. Math. Klasse Akad. Wiss. Berlin; Gilb. Ann., 38, 349-432; confer reference 684: $3222,32221,72,73$.

1812

21. Meissner, W. Hermbstädt. Bull., 10, 160-8: 721 .

22. Dubuc, G. Ann. chim. phys. (I), 86, 314-36; Gilb. Ann., 46, 187 ( $18 \mathrm{I}_{4}$ ): 63 IIr.

23. Meissner, P. T. Trommsdorff. J. Pharm., 21, 12, and 22, 3-42: 721 .

24. Hutton. Gilb. Ann., 45, Ir9-27; Schweigger, J., 8, I28-30 (1813); 19, 301-7 (1817): 2234, 3234, 63123. 
25. Gay-Lussac, L. J. Ann. chim. phys. (I), 95, $311-8$; Mem. Soc. d'Arceuil, 3, 102 (1817): 16, 2222, 631132,

26. Gay-Lussac, L. J. Ann. chim. phys. (2), 2, I30-6: 22221 .

27. Meissner, W. Wien (pp. 8r, 83): 2222, 631143,71 .

\section{0}

28. Gay-Lussac, L. J. Ann. chim. phys. (2), 13, 62 (p. 78): 5213 .

29. Sömmerring, S. T. von. Denkschr. Akad. München (1818-20), 245-64; (1823-24), 10I-20: 3227, 63124 .

\section{1}

30. Lamberti, A. von. Treatise, Dorpat: $7 x$.

\section{2}

31. Gröning, Fr. Edin. Phil. J., 7, 214-6; Schweigger. J., 39, 473-86 (1823): 3228, 3233, 723.

1823

32. Delezennes. Trans. Soc. Agric. Sci. Arts. Lille,, 3, 1-3I; Ferrusac's Bull. Univ. Sci. Math., 8, 132 (I826); J. de phys., 94, 204: 2222.

33. Hensmans, P. J. Mém. Couronn. Brussels, 4: II.

34. Sömmerring, S. T. von. Denkschr. Akad. München 97-100: 3228.

\section{4}

35. Gay-Lussac, L. J. Treatise, Paris. Instructions pour l'usage de l'alcoomètre centesimal et des tables qui l'accompagnent: 72,73 .

36. Yelin, J. C. von. Arch. Naturl. Kastner., 3, 340-51: 3228.

37. Yelin, J. C. von. Arch. Naturl. Kastner., 3, 375-7: 2233.

\section{5}

38. Gouvernain, C. A. de. Ferrusac's Bull. Univ. Sci. Math., 7, 147: 2222.

39. Kömer, F. Jena. Über Alkoholometer: 72.

\section{7}

40. Colladon, D. et C. Sturm. Ann. chim. phys. (2), 36, 113-59, 225-57; Pogg. Ann., 12, 39, 161-97 (1828): 22222, 32222.

41. Dumas, J. B. et Boullay, fils. Ann. chim. phys. (2), 36, 294-310 (p. 297); Pogg. Ann., 12, 93-ro8 (1828): 2222, 631143 .

42. Graham, Th. Trans. Roy. Soc. Edinb.; Phil. Mag., 4, 265-72, 331-6 (1828); Pogg. Ann., 15, 150-3 (1829): 521.

43. Gröning, F. Berlin: 3233,723 .

*44. Rudberg, F. Akad. Handl. Stockholm. 1-163; Pogg. Ann., 13, 496-502 (1828); Ann. chim. phys. (2), 48, 33-4I (183I): 32224 .

45. Berzelius, J. Traité de Chimie, Paris, 6, p. $488: 73$.

46. Limvus. Diss. Bonn: 22221, 32221.

*47. Muncke, M. Acad. Savant. Ètrangers, Petersburg 1, 249-4I4 (183I): 2222I, 32221.

48. Brown, R. Pogg. Ann., 17, 162: 2222, 2234.

49. Jourdan, T. F. Diss. Montpellier: 11.

50. Tabarie, E. Ann. chim. phys. (2), 45, 222: 721 .

51. Tigne, J. P. Diss. Montpellier: $I I$. 


\section{4}

*52. Muncke, M. Acad. Savant. ìtrangers, Petersburg, 2, 483-522 (1835); Ann. chim. phys. (2), 64, 5-52 (1837); Gehler's Wörterbuch, 10, 935: 2222, 22221.

\section{5}

53. Connel, A. Edin. New. Phil. J., Trans., 19, 159-63; Pogg. Ann., 36, 487-93; J. prak. Chem., 5, 167-206: $2222,525,631132$.

54. Dumas, J. et E. Pêligot. Ann. chim. phys. (2), 58, 5-74; Lieb. Ann., 15, 1-6o; Pogg. Ann., 36, 88-138: 2222. 55. Liebig, J. Pogg. Ann. 36, 275-308: 52Ir, 526 .

\section{6}

56. Magnus, G. Pogg. Ann., 38, 48I-92: 3227, 3233.

\section{7}

57. Löwig, C. Pogg. Ann., 42, 399-4I4: 63II.

58. Pouillet. Pogg. Ann., 41, I44-52 (p. 149): 2234.

\section{9}

59. Despretz, C. Ann. chim. phys. (2), 70, I-8I (p. 48, 74): 3222, 81 .

*60. Soubeiran, E. Lieb. Ann., 30, 356-6r; J. prak. Chem., 17, 91: 3228, 5213, 63II32, 63II4I, 63II43, 631147

\section{1}

61. Frankenheim, M. L. und Sondhauss. J. prak. Chem., 23, 40I-35 (p. 423): 2225.

62. Kopp, H. Monograph, Frankfurt a/M (p. I32): 2, 2222.

63. Kopp, H. Lieb. Ann., 40, 206: 423 .

*64. Kopp, H. Pogg. Ann., 53, 356-62: 3222 .

65. Ure, A. Phil. Mag. (3), 19, 5 II $^{-13}$; Pharm. J., 2, 695-702 (1843): 21, 2122, 21221.

66. Veron, A. Monograph, Paris: 12 .

\section{2}

67. Brix, A. W. Lieb. Ann., 94, 162-9; Pogg. Ann., 55, 341-90 (p. 384): 2237.

*68. Brossard-Vidal, Abbé. C. r. acad. sci., Paris, 14, 816; 16, 39, I40, 317, 756 (1843): 72.

69. Deville, H. Ann. chim. phys. (3), 5, 129-43 (p. 136): 226r, $326 r$.

*70. Francoeur, L. B. C. r. acad. sci., Paris, 14, 328-31: 7I, 721 .

71. Kopp, E. Diss. Strasburg: 5211 .

72. Poiseuille. C. r. acad. sci., Paris, 15, II67; Ann. chim. phys. (3), 7, 50 (1843); Pogg. Ann. 58, 424-48 (I843): 2226, 3226 .

73. Hesse, G. Treatise, St. Petersburg: 721 .

74. Kopp, H. Lieb. Ann., 46, 215-21: 13, 52I.

75. Regnault, V. Ann. chim. phys. (3), 9, 322-49 (p. 348-9); Pogg. Ann., 62, 50-8r (1844): 2222, $22221,223 I$.

76. Reiset, J. et E. Millon. Ann. chim. phys. (3), 8, 280-92 (p. 290): 522, 526.

77. Rieckher, Th. Lieb. Ann , 46, 222-7: 2.

\section{4}

78. Connel, A. Trans. Roy. Soc., Edin., 15, 151-64: 525.

79. Kopp, H. Pogg. Ann., 63, 283-316, and 65, 89-100 (1845): 2222, 2233.

80. Natterer, J. Pogg. Ann., 62, 132-6: 2234 .

\section{5}

81. Faraday, M. Phil. Trans., 155-77; Ann. chim. phys. (3), 257-90; Pogg. Ann., 64, 467-72; Pogg. Ann. Ergb., 72, 193-227 (I848): 2234.

82. Kopp, H. Lieb. Ann., 55, 166-200: 2233.

83. Kopp, H. J. prak. Chem., 34, I-36: 2222, 2233.

*84. Pierre, J. Isidore. Ann. chim. phys. (3), 15, 325-408 (p. 351); C. r. acad. sci., Paris, 23, 443-9, 594-8 (1846); Ann. chim. phys. (3), 19, I93-22I (1847): 2222, 2222I, 3222, 3222I, $2233,63 I 132$.

85. Regnault, v. Oeuvres Tome II, pp. $183,813,896: 2237$.

86. Baden-Powell. Pogg. Ann., 69, rro-5: 226r.

\section{6}

87. Brossard-Vidal, Abbê. C. r. acad. sci., Paris, 23, rr ro; 27, ro3, 374, 431, 526 (1848): 723.

88. Cassoria. J. chim. med.: 6III46.

89. Favre, P. et J. T. Silbermann. C. r. acad. sci., Paris, 23, 41I-3; 29, 449-5r (I849): 3239. 
*90. Fownes, G. Phil. Trans., 137, 249-52: 2222, 3222, 6r, 631132, 631142, 73.

91. Frankenheim, M. L. Pogg. Ann., 72, 177-222 (p. 200): 2225, 32224.

*92. Kopp, H. Lieb. Ann., 64, 2 12-9 (p. 213); Pogg. Ann., 72, 1-62, 223-93: 2, 2222, 22221, 2233.

*93. Pierre, J. Isidore. Ann. chim. phys. (3) ,20, 5-52, I; (3), 31, 118-152, 33, 199-244 (185r); Pogg. Ann., $83,86-7$ ( 1851$): 2,2222,22221$.

94. Poiseuille. Ann. chim. phys. (3), 21, 76-110: 2226.

95. Steinheil. München: 3228,7 .

96. Ure, A. J. Arts and Sciences, London, 31, 29r; Pharm. J., 7, 166-75 (1848); J. B., (r847-48) 48, 683: 723.

*97. Wackenroder, H. Arch. Pharm., 50, 162-7; J. B. (1847-48) 682: 2222, 631132.

98. Wagner, J. R. Lieb. Ann., 40, 448; J. prak. Chem., 40, 448: 423.

\section{8}

99. Andrews, T. Pogg. Ann., 75, 50I-17; J. Chem. Soc., London, 1, 27-41 (1849): 223.

100. Conaty, M. (See Despretz, 1848.) J. pharm. chim. (3), 20, 332: 723.

101. Despretz, C. C. r. acad. sci., Paris, 27, $374 ;$ J. B. $(1847-48) 683: 723$.

*102. Drinkwater, J. Phil. Mag. (3), 32, 123-9; London Chem. Soc. Mem., 685; J. B., (1847-48) 682: 2222, $631132,631142,631145,73$.

103. Grassi, C. C. r. acad. sci., Paris, 27, 153-4; Ann. chim. phys. (3), 31, 437-78 (1851) (p. 458$): 22222$.

104. Kopp, H. Pogg. Ann., 75, 98-108 (p. 103): 2231.

*105. McCulloh, R. S. United States of America, 3oth Congress, ist session, Exec. Doc. No. 50, pp. 39754I: $3222,721,73,74$.

106. Silbermann, J. T. C. r. acad. sci., Paris, 27, 4r8-21; J. B. (1847-48) 684: 722.

107. Voegeli, F. Pogg. Ann., 75, 282-319 (p. 295): 5213.

108. Wertheim, G. C. r. acad. sci., Paris, 27, r5o-2; Ann. chim. phys. (3), 23, 434-75 (p. 472), Pogg. Ann., $77,427-45,544-71$ (1849): 2272.

109. Wetherill, C. M. Lieb. Ann., 64, II7-25; Trans. Am. Phil. Soc., 10, I77-82 (I853): 2222.

\section{9}

110. Boussingault, M. Ann. chim. phys. (3), 25, 263-5: 3234 .

111. Bussy, A. J. de pharm., 15, 889-103: $722,723$.

112. Despretz, C. C. r. acad. sci., Paris, 28, 143-4; J. prak. Chem., 47, 466-7: 2234.

113. Stampfer, S. Sitzb. Akad. Wiss., Wien., Abt. II, 304-17: 721.

\section{0}

114. Becquerel, E. C. r. acad. sci., Paris, 31, I98-201; Ann. chim. phys. (3), 32, 68-II2 (185I) (p. 315): 2251. 115. Makins, G. H. J. Chem. Soc. London, 2, 224-31: 3222, 32221, 721 .

116. Pohl, J. J. Sitzb. Akad. Wiss., Wien., 5, 246-51; J. B., 455, 6II: 3233, 723.

\section{1}

117. Gorgeu, A. C. r. acad. sci., Paris, 33, 690-2; J. prak. Chem., 21, 259-66 (1852): 61123, 631 .

118. Lerebours et Secretan. J. pharm. chim., 333; Ding1, Poly. J., 122, 363-5: 723.

119. McCulloh, R. S. United States of America, 3 Ist Congress, and session, Exec. Doc. No. 28, pp. I-I68. A Report (to the Treasury Department) of the Computation of Tables to be used with the Hydrometer recently adopted for use in the United States Custom-houses: 73.

120. Pohl, J. J. Sitzb. Akad. Wiss., Wien., 6, 571-601; J. prak. Chem, 56, 210-2 (1852): 423.

121. Stampfer, S. Sitzb. Akad. Wiss., Wien., 253-65: 72.

\section{2}

122. Frankenheim, L. Pogg. Ann., 86, 45I-64: 81,82 .

123. Pliicker und Geissler. Pogg. Ann., 86, 238-79: 81,82 .

124. Stampfer, S. Denkschr. Akad. Wiss. Wien., 3, 237-68: 72.

\section{3}

125. Favre, P. A. et J. T. Silbermann. Ann. chim. phys., (3), 37, 406-508 (p. 467): 3230.

126. Stadion, J. Königsberg: 721 .

127. Wetherill, C. M. J. Frank. Inst., 25, 385-9r; J. prak, Chem., 60, 202-4; J. B., 44r: 6r 5 . 
128. Delffs, W. Lieb. Ann., 92, 277-9; J. B., 26: Jahrbuch. Pharm. I, I: 2222, 2233, 2261.

129. Geissler, Arch. d. Pharm. (2), 82, 198-9; Fortsch. d. Physik. 385: 723.

130. Graham, T. British A. A. S. Reports. II, 69: 3227,3228.

131. Kupffer, A. T. von. C. r. l'observ. phys. de Russie 14: 7 .

132. Pliicker, J. Pogg. Ann., 92, 193-220 (p. 205); Lieb. Ann., 92, 209; J. B., 54: 2221, 2222, 2227, 322I, 3222, $32224,3227,631132,723$.

133. Regnault, V. C. r. acad. sci., Paris, 39, 301-14, 345-57, 397-409; Pogg. Ann., 93, 537; Lieb. Ann. 92, 196; Phil. Mag. (4), 8, 269; 9, 4 (1855): 2227, 3227.

134. Youmans, E. L. Treatise, New York: $I I$.

\section{5}

135. Carius, L. Lieb. Ann., 94, 129-66; Ann. chim. phys., (3), 47, 418-9 (1856): 421.

136. Clerget, J. Bull. soc. d'encouragement ind. nat. France, 193-7: 72.

*137. Kopp, H. Lieb. Ann., 94, 257-320; 95, 307-56; 98, 367-76 (1856): 2222, 22221, 2233.

138. Kopp, H. Lieb. Ann. 96, I-36, 153-85, 303-35 (p. 163 ); 100, 19-38 (1856): 2.

139. Schönfeld, F. Lieb. Ann., 95, I-23: $42 x$.

140. Stein, Dingl. Poly. J., 138, 429: 631, 635

\section{6}

141. Berthelot, M. Ann. chim. phys. (3), 46, 180-2; Lieb. Ann., 98, 180-1: 5213.

142. Long, J. London, Tables for the Strength of Spirits: 73.

143. Miller, W. H. Phil. Trans., 146, $753-946$ (p. 788 ): 81,82 .

\section{7}

144. Grailich, W. J., und A. Handl. Sitzb. Akad. Wiss. Wien., 25, 515-9: 31, 3122, 316I, 32, 3222, 3261. 145. Masson, A. C. r. acad. sci., Paris, 44, 466-7; Ann. chim. phys. (3), 53, 257-92 (1858): 2, $2271,2272$. 146. Valson, C. A. C. r. acad. sci., Paris, 45, 10-13; 46, 95-7 (1858): 2225, 724.

\section{8}

147. Dale, T. P., and J. H. Gladstone. Phil. Trans., 148, 887-94 (p. 89r): 226 I.

148. Langberg, Chr. Meddel. Arndsen, Christiania; Pogg. Ann., 106, 299-307 (1859); Phil. Mag. (4), 18, II3-9 (1859): 721 .

149. Rieckher, N. Jahrb. Pharm., 10, 308: 631.

150. Vogel, A. Sitzb. Akad. Wiss. Wien,. 30, 261-9: 3227.

1859

151. Otto. Braunschweig, Lehrbuch d. rat. Praxis d. landwirthschaftlichen Gewerbe, ste Auflage, Band I. p. 413: 2233, 3233.

152. Pouillet, M. C. r. acad. sci. Paris, 48, 929-31; 51, 1002 (1860); 54, 357 (I861); Mem. Acad Franc., 30, 407 (1860); J. B., 439: 2222, 3222, 721.

153. Schnidaritsch, A. Sitzb. Akad. Wiss. Wien. 38, 39-68: 323I.

1860

*154. Baumhauer, E. H. von. Monograph, Amsterdam. Verhandeling over de digtheid, de uitzetting, de kookpunt en de spannung van den damp van alkohol en van mengels van alkohol en water: 2222, 22221, 2227, 2233, 3222, 32221, 3227, 3233 .

*155. Baumhauer, E. H. von. C. r. acad. sci. Paris, 50, 591-2; Lieb. Ann., 116, 253-4; Pogg. Ann., 110, 659-60; J. B., 393; C. B. (2), 5, 484: 2222, 3222, 631132, 631142.

156. Favre, P. A. C. r. acad. sci. Paris, 51, 316-8; J. B., 35: 3239.

157. Mendeléeff, D. C. r. acad. sci. Paris, 50, 52-4; Z. Chem., 782: 2225.

158. Mendelêeff, D. C. r. acad. sci. Paris, 51, 97; C. B. (2), 5, 731; J. B., 7: 2225.

159. Regnault, V. C. r. acad. sci. Paris, 50, 1063-75; Pogg. Ann., 111, 402; Phil. Mag. (4), 20, 275; J. B. 38-9: 222.

160. Wüllner, A. Pogg. Ann., 110, 387-96: 631.

\section{1}

161. Baumhauer, E. H. von. Verslag. Akad. Amsterdam, 11, 409-15: 721.

162. Baumhauer, E. H. von. Pogg. Ann., 113, 639-47: 721 . 
163. Baumhauer, E. H. von. Tables, Leipzig: 721,73 .

164. Baumhauer, E. H. von et F. H. van Moorsel. Tables, Amsterdam: 72I, 73.

165. Baumhauer, E. H. von und Pouillet. Lieb. Ann., 117, 391-2: 2222, 3222.

166. Berthelot, M. Ann. chim. phys. (3), 61, 460-2: 5211, 5213 .

167. Chevreul, Despretz, Fremy et Pouillet. C. r. acad. sci. Paris, 53, 615-8: 72.

168. Collardeau, M. C. r. acad. sci. Paris, 53, 925; Lieb. Ann., 122, 375-6 (1862): 2222, 3222, 73.

169. Graham, T. Phil. Trans., 151, 373; C. r. acad. sci. Paris, 53, 774-7; Lieb. Ann., 123, 105 (1862): 2226, 3226.

170. Hoek, M. Pogg. Ann., 112, 347-50: 226r, 326r.

171. Kupffer, A. T. von. Bull. acad. Petersburg, 3, 355: 71 .

172. Mendeléeff, D. Lieb. Ann., 119, I-II; C. B. (2), 6, 766; J. B., 20: 2221, 2222, 22221, 2233.

173. Ruau, L. Ann. chim. phys. (3), 63, 350-9: 73 .

174. Schiff, H. Lieb. Ann., 118, 362-72: 423 .

\section{2}

175. Baumann, Z. Ver. deutsch. Ing., 6, 483: 721 .

176. Dronke, F. Diss. Marburg (p. I 7): 2227, 3227.

177. Friedel, C. C. r. acad. sci. Paris, 55, 53-8; Chem. News., 6, 148-9; Lieb. Ann., 124, 324-30: 15, 632, 636.

178. Il'ish, F. Treatise, St. Petersburg: 71 .

179. Regnault, V. Mém. inst. franc., 26, I-915: 223, 2231.

180. Wildenstein, $R$. Z. anal. Chem., 1, I62-5: 72I,

181. Wurtz, C. A. C. r. acad. sci. Paris, 54, $915^{-20}$; Lieb. Ann., 123, 140-4; Ann. chim. phys. (4), 2, 438-4I (1864): $15,5213,632$.

182. Lieb. Ann., 122, 375-6 (confer references 168 and r73); Dingl. Poly. J., 166, 392: 73.

\section{3}

*183. Berthelot, M. C. r. acad. sci. Paris, 56, 871-3; Ann. chim. phys. (3), 68, 362-4; Chem. News., 7, 279-80; $\mathrm{Z}$. anal. Chem., 2, 224: 61, 631132, 631133.

184. Berthelot, M. C. r. acad. sci. Paris, 57, 430-4; Lieb. Ann., 128, 321-7: 3228,6 .

185. Berthelot, M. C. r. acad. sci. Paris, 57, 797-8; Chem. News., 8, 293: 5211.

186. Berthelot, M. C. r. acad. sci. Paris, 57, 985-6; Ann. chim. phys (4), 1, 384-92 (1864): 3228, 63 I21.

187. Gaultier de Claubry. Bull. soc. d'encouragement ind. nat. France, 516-24: 723 .

188. Gladstone, J. H. and T. P. Dale. Phil. Trans., 153, 317-43 (p. 325, 338): 2222, 2261, 2265.

189. Maumené, E. J. C. r. acad. sci. Paris, 57, 955-7, 1033: 3228, 63121, 723.

190. Musculus, F. Mém. méd. milit., 10, 465-75; C. B. (1864), 922-5; J. B. (1864), 5: 2225, 3225.

191. Wanklyn, J. A. Proc. Roy. Soc. London, 12, 534-5: 3228 .

192. Wilhelmy, L. Pogg. Ann., 119, 177-217: 2225, 3225.

\section{4}

193. Alluard, M. C. r. acad. sci. Paris, 58, 82-5; Ann. chim. phys. (4), 1, 243-54; Pogg. Ann., 123, 190: $3227,3233$.

194. Brix, A. W. Monograph, Preuss. Normal-Eichungs-Kommission (3te Auflage), Berlin: 721 .

195. Brossard-Vidal. Dingl. Poly. J., 171, I46; Z. anal. Chem., 3, 223: 6212, 7.

196. Bussy, A. et H. Buignet. C. r. acad. sci. Paris, 59, 673-88, $785^{-6}$; Ann. chim. phys. (4), 4, 5-27 (1865); C. r. acad. sci. Paris, 64, 330-9 (1867): 3239 .

197. Favre, P. A. C. r. acad. sci. Paris, 59, 783-5: 3239.

198. Jacobi, H. Bull. acad. sci. Petersburg, 7, 438-51: 721.

199. Landolt, H. Pogg. Ann., 122, 545-63 (p. 547): 21, 2222, 2233, 2261, 2265, 631111, 63113?.

200. Salleron, J. Paris: 7,87 .

201. Wagner, R. Dingl. Poly. J., 172, 380: 723.

\section{5}

202. Fresenius, R. Z. anal. Chem., 4, 177-85: 85 .

203. Gerardin, A. Ann. chim. phys. (4), 5, 129-60: 423.

204. Kupffer, A. T. von. Treatise, Berlin: 71 .

*205. Landolt, H. Lieb. Ann. Suppl., 4, 1-23: 62121, 62122, 7.

206. Linnemann, E. Lieb. Ann., 136, 37-69: 13 .

*207. Mendeléeff, D. Diss. St. Petersburg; Z. für Chem., 257-64; J. B., 469; C. B. (2), 11, 224 (I866)

Phil. Mag. (4), 31, 137 (1866): 2222, 22221, 22223, 3222, 32221, 6111, 631132, 631133, 73.

208. Musculus, F. Mém. méd. milit., 13, 74-80: 2225, 3225, 724.

209. Schiff, H. C. r. acad. sci. Paris, 61, 45-7: 61214. 
210. Baumhauer, E. H. von. Archiv. Néerl., 1, 465-8: 721 .

211. Berthelot, M. Ann. chim. phys. (4), 9, 425: 421.

212. Duplats, P. Monograph, Paris. 3228.

213. Friedel, C. et J. M. Crafts. Ann. chim. phys. (4), 9, 5-51 (p. ro): 521, 631132

214. Geissler, H. Sitzb. Niederrhein. Ges. Bonn., r2-4; Dingl. Poly. J. 180, r46: 723.

*215. National Academy of Sciences, U. S. A. Tables, Washington; Senate Misc. Documents, No. 44, (1867): 73,74.

*216. Recknagel, G. Sitzb. k. Bay. Akad. Wiss. München., 2, 327; Z. anal. Chem., 6, 269 (r867); Carl's Repert. Physik. 4, II9 (1868): 3222, 3222 I

217. Wüllner, A. Pogg. Ann., 129, 353-66: 3227.

\section{7}

218. Berthelot, M. C. r. acad. sci. Paris, 64, 410-3: 3239.

219. Berthelot, M. Bull. soc. chim. (2), 8, 387-9: 521, 5213.

220. Hirn, G. A. Ann. chim. phys. (4), 10,32-92 (p. 48); (4), 11, 5-Irr, (p. 10): $22221,2231$.

221. Landolt, H. Sitzb. Niederrhein. Ges. Bonn, 12-3: 523 .

222. Linnemann, E. Lieb. Ann., 144, 129-137: 14 .

223. Siersch, A. Lieb. Ann., 142, III-2I: 14 .

224. Siersch, A. Lieb. Ann., 144, 137-45: 14.

\section{8}

225. Darling, W. H. J. Chem. Soc. London, 6, 496-506; Lieb. Ann., 150, 216-24 (1869) (p. 222): 2222.

226. Dupré A. and F. J. M. Page. Phil. Mag. (4), 35, 464: 323r.

227. Fouqué, F. Ann. de l'Observ. Paris, 9, I72-25I (p. 250): 2261 .

228. Landolt, H. Lieb. Ann. Suppl., 6, 129-8I (p. 173): 2227.

229. Lebraigne, E. J. pharm. chim. (4), 7, 81-93: 724 .

230. Linnemann, E. Lieb. Ann., 145, 38-42: 14 .

231. Linnemann, E. Lieb. Ann., 148, 249-63: 2222, 2233.

232. Reynolds, R. Pharm. J. and Trans. (2), 9, 171; Z. anal. Chem., 7, $358: 72$.

233. Siersch, A. Lieb. Ann., 145, 42-6: 14, 633 .

234. Wüllner, A. Pogg. Ann., 133, 1-53: 2222, 226r, 2265.

\section{9}

235. Amaury et Descamps. C. r. acad. sci. Paris, 68, 1564-5; Phil. Mag. (4), 38, 164-5: 22222.

236. Berquier et Limousin. J. pharm. chim. (4), 8, 24r-4; Z. anal. Chem., 8, $5 \mathrm{I}_{3}: 724$.

*237. Duprê, A. and F. J. M. Page. Phil. Mag. (4), 38, r58; Pogg. Ann. Errg'b., 5, 22 I-42, 6I4 (187r); Pogg. Ann. 148, 238 (1873): 2222, 22221, 22222, 2225, 2231, 2233, 3222, 32221, 32222, 3225, 3231, 3233, 3239.

238. Gerlach, G. Th. Z. anal. Chem., 8, 245-97 (p. 295): 73.

239. Lauth, Ber. chem. Ges., 2, 105; (conf. M. Berthelot, ibid., 8, 696 (1875)): 614

240. Lüdtge, R. Pogg. Ann., 137, 362-77; Ann. chim. phys. (4), 18, 500-2; Phil. Mag. (4), 38, 468-70: 2225.

241. Mendeléeff, D. Pogg. Ann., 138, 103-41, 230-79 (confer reference 207).

242. Rosseti, F. Atti. Inst. Venet., 15, 1297-1313; Pogg. Ann., 140, 329-31 (1870); C. r. acad. sci., Paris, 70, 1092-3 (1870); Ann. chim. phys. (4), 23, 76-77 (1871); C. B. (1870) 1072: 3222, 32224, 3234.

243. Saïd-Effendi, M. C. r. acad. sci., Paris, $68,1565-7: 2241$.

244. Wanklyn, J. A. Phil. Mag. (4), 37, rr7: 5213.

245. van der Willigen, V.S. M. Archiv. Musee Teylèr, 2, 208-17: 2222, 226r, 2263, 3222, 326r.

\section{0}

246. Amaury, J. Jamin et Descamps. C. r. acad. sci., Paris, 70, I237-42: 323I.

*247. Baumhauer, E. H. von. Archiv. Néerl., 5, 97-112; Pogg. Ann., 140, 349-66: 2222, 2222I, 3222, 32221. 248. Dupré, A., and F. J. M. Page. Phil. Trans., 159, 59 (confer reference 237): 21 .

249. Jamin, M. C. r. acad. sci., Paris, 70, I309-I2: 3239.

250. Jamin, M. C. r. acad. sci., Paris, $71,23-9$ (p. 27): 3239.

251. Mendeléeff, D. Pogg. Ann., 141, 618-26 (p. 622): 2223 .

1871

252. Berthelot, M. C. r. acad. sci., Paris, 73, 496-7: 614.

253. Berthelot, M. C. r. acad. sci., Paris, 73, 663-8r: 52 r. 
254. Erlenmeyer, E. Lieb. Ann., 160,249-50; C. B. (1872), 80; J. Chem. Soc. London, Abst., 25, 133 ( 1872 ): $2222,63 I 132$.

255. Fehling, H. von. Braunschweig, Neues Handwörterbuch der Chemie. Band I, p. 253-9 Alkohol; p. $267-84$ Alkoholometrie: $I I, 7 I$.

256. Lieben, A. Lieb. Ann., 158, 5I, I37: Ber. chem. Ges. 3, 907-II (1870): 521 .

257. Linnemann, E. Sitzb. Akad. Wiss. Wien, 63, II, 673-8: 54, 5413 .

258. Linnemann, E. Lieb. Ann., $160,195^{-242}$ (p. 211 ): 3228,87 .

259. Norm. Eich.-Komm. d. Norddeutschen Bundes Tafeln, Berlin: 73.

260. Pierre, J. Isidore, and É. Puchot. Ann. chim. phys. (4), 22, 234-36r: I6, 2222.

261. Pinsonet, A., et J. Petit. Paris: 721 .

262. Saytzeff, A. J. prak. chem. N. F., 3, 76-88: 14, 15, 636 .

263. Schüller, J. H. Pogg. Ann. Ergb., 5, ir6-46, 192-221; J. B. (1870), 90: 3231.

264. Bouvier. Z. anal. chem., 11, 343: 615 .

1872

265. Cailletet, L. C. r. acad. sci., Paris, 75, 77-8: 22222.

266. Delaunay. Patent Spec., France., Mch., II; Ber. chem. Ges., 6, 1 I 39 ( 1873 ): 722.

267. Duclaux, E. J. de phys., 1, 197-203: 2225, 3225, 721 .

268. Duclaux, E. Ann. chim. phys. (4), 25, 433-502 (p. 460): 2226, 3226.

269. Dupré, A. Phil. Trans., 162, 33I-5I: 2I, 3I.

270. Erlenmeyer, E. Lieb. Ann., $162,373-88$ (p. 374): 5213, 523

271. Fischern, Th. Treatise, Dresden: $7 I$.

272. Jacobi, H. Mém. acad. sci. Petersburg, 17, No. 5: $721,73$.

273. Jullian, L. Paris: $7 I$.

274. Lejeune, Y. M. Monograph, Brest; Archiv. d. Méd. Navale, 19, 14I-6 (I873): 721 .

275. Liebig, J. Handwörterbuch der Chemie, Band I, 202-II Alkohol; 2 I2-65 Alkoholometry: $I I, 7 I$.

276. Linnemann, E. Lieb. Ann., 161, 18-25; Ann. chim. phys. (4), 26, 564-72: 14 .

277. Linnemann, E. Lieb. Ann., 161, 43-70: 53 .

278. Linnemann, E. Lieb. Ann., 161, 178-90: 14 .

279. Pierre, I. et E. Puchot. Ann. chim. phys. (4), 26, 145-7r: $33,3328,87$.

280. Cintolesi, F. Ber. chem. Ges., 6, 143: 3228 .

1873

281. Kraft, A. Z. anal. Chem., 12, 48-66; J. prak. Chem. N. F., 7, 228-47: 624, 7.

282. Krell, G. Ber. chem. Ges., 6, 1310-2: 623 .

*283. Pier re, J. Isidore. C. r. acad. sci. Paris, 76, 336-7; Chem. News. Abst., 27, 93: 2222, 63, $631132,631142$. 284. Squibb, E. Am. Pharm. Assoc. Proc., 548, 566; J. B., (I874) $328: 73$.

285. Winkelmann, A. Pogg. Ann., 150, 592-619 (p. 603); 151, 512 (1874): 2222, 323I, 3239.

\section{4}

286. Bullock, C. Pharm. J. (3), 4, 89r; J. B., 327: 631132 .

287. Duclaux, Ê. C. r. acad. sci. Paris, 78, 95I-3; Ann. chim. phys. (5), 2, 233-53: 71 .

288. Grodski, M. und G. Kraemer. Ber. chem. Ges., 7, 1492-7: 51, 623, 626, 628 .

289. Malligand, E. et E. Brossard-Vidal. C. r. acad. sci. Paris, 78, 1470: 723 .

290. Salleron, J. C. r. acad. sci. Paris, 78, Ir $47-50$; Fortschr. Phys., 294: 624, 71 .

291. Smith, J. Lawrence. Am. Chemist, 5, r20; Chem. News, 30, 234; J. B., 328; Am. J. Pharm., 47, 31 (1875); Arch. Pharm. (3), 5, 355 (1876): 63r132.

292. Bernard, A. Paris: $7 I$.

\section{5}

293. Berthelot, M. C. r. acad. sci. Paris, 80, 1039-40; Ann. chim. phys. (5), 9, 54-6 (1876): 614 .

294. Guthrie, F. Phil. Mag. (4), 49, 266-76 (p. 270); Chem. News, 31, 49: 3234 .

295. Malligand, M. C. r. acad. sci. Paris, 80 , III4-33: 723.

296. Oberbeck, A. Pogg. Ann., 155, 595-602: 2241.

297. Stefanelli, P. Ber. chem. Ges., 8, 439; Z. anal. Chem., 14, 37r: 6r4.

298. Ure's Dictionary of Arts, 7 th Edition, Vol. I, 42-65, Alcohol and Alcoholometry: II $_{7}$ I.

\section{6}

299. Cossa, A. Atti acad. 'iorino, 11, 938-46: 723 .

300. Dibbits, H. C. Z. anal. Chem., 15, I2I-70: 85 .

301. Dittmar, W., and D. Steuart. Chem. News, 33, 53; Proc. Phil. Soc. Glasgow, 10, 63-70 (1877): 3. $3227,3233,6,87$. 
302. Duclaux, E. J. de Phys. (x), 5, 13-9: 2223, 3223.

303. Gladstone, J. H., and A. Tribe. J. Chem. Soc. London, 29, 158-62: 5213.

304. Herwig, H. Pogg. Ann., 159, 61-93 (p. 65): 3241.

*305. Hoh, Th. Naturf. Gesell. Bamberg, 11, 77; Pogg. Ann., 158, 334-6: 2222, 22221, 3222, 32221.

306. Kraemer, G., und M. Grodski. Ber. chem. Ges., 9, 1928-32: 613, 623 .

307. Maumené, E. J. Ann. chim. phys. (5), 9, 499-570; C. r. acad. sci. Paris, 83, 67-70: 3228, 7, 723, 87 .

308. Salleron, J. J. pharm. chim. (4), 24, 33-5: 3233, 723.

309. Savalle, D. Treatise, Paris: 87 .

\section{7}

310. Bunsen, R. Treatise, Braunschweig. Gasometrische Methoden, ate Auflage (p. 384 ): 421 .

311. Claus, Ad. Ber. chem. Ges., 10, 925-30: 61115.

312. Duclaux, E. C. r. acad. sci. Paris, 85, 1068-9; Ann. chim. phys. (5), 13, 76-101 (1878) (p. 88): 2222, 2225.

313. Karmarsch, K. Dingl. Poly. J., 226, 441-55: 32221.

314. Lecher, E. Sitzb. Akad. Wiss. Wien, 76, II, 937-45: 3I, 31 31.

315. Morrell, T. T. Pharm. Centralhalle, 17, 394; Z. anal. Chem., 16, 251: 521, 624 .

\section{8}

316. Bleekrode, L. Phil. Mag. (5), 5, 375-89, 439-451; Wied. Ann., 3, r6r: 224I, 525.

317. Bourgoin, E. Bull. soc. chim. (2), 29, 242; Z. anal. Chem., 17, 502: 42, 423 .

318. Eder, J. W. J. prak. Chem. N. F., 17, 44-7: 423.

319. Henze, Hr. Ber. chem. Ges., 11, 677: 86.

320. Jehn, C. Ber. chem. Ges., 11, 360-2: 86.

321. Kohlrausch, F. Pogg. Ann. Ergb., 8, I-16: 224I, 6r.

322. Kundt, A. Wied. Ann., 4, 34-54: 21, 2222, 226I, 2264, 2265.

323. Le Bel, J. A. C. r. acad. sci. Paris, 87, 260-I: 323.

324. Mackenzie, J. J., and E. L. Nichols. Wied. Ann., 3, I34-42: 22223.

325. Muiller-Erzbach, W. Ber. chem. Ges., 11, 409: 85 .

*326. Pierre, J. Isidore. Caen (Compilation of Earlier Works): 2222, 22221, 3222, $32221,88$.

327. Pribram, R., und A. Handl. Sitzb. Akad. Wiss. Wien (2), 78, 113-64; (2), 80, 17-57 (1879); (2), 84, II, 717-89 (1881): $25,2526$.

328. Puluj, J. Sitzb. Akad. Wiss. Wien, 78, II, 279-3rr: 2226.

329. Riche, A., und Ch. Bardy. Z. anal. Chem., 17, 221-2: 614.

330. Thresh, J. C. Chem. News., 38, 251-3; J. Chem. Soc. London, 36, 279-80 (1879); Z. anal. Chem., 18, 487 (1879): 614, 624 .

331. Wijkander, A. Lunds. Physiogr. Sällsk. Jubelskrift; Wied. Ann. Beib., 3, 8-II (1879): 2226.

\section{9}

332. Bartoli, A. Nuovo Cimento., 6, I41-53; Wied. Ann. Beib., 4, 332 (1880); Mem. Acad. Linc. (3), 19, 577 (1883): 2222, 2225, 2231 .

333. Brihhl, J. W. Ber. chem. Ges., 12, 2135-48; 13, $1119-30,1520-35$ (1880); Lieb. Ann., 200, 139-234 (1880); $203,1-63,255-86,363-8$ (1880): $13,2,2222$.

334. Haller, A. Treatise, Paris, Théorie générale des alcool; $x$.

335. Jamin et Amaury. C. r. acad. sci. Paris, 70, 1237-43: 3231.

*336. Le Bel, J. A. C. r. acad. sci. Paris, 88, 9 12-3: 63121 .

337. Leeds. J. Am. Chem. Soc., 1, 38: 6rit.

338. Ramsay, W. J. Chem. Soc. London, 35, 463-74 (p. 469): 2221, 2222.

339. Rodenbeck. Diss. Bonn: $3225,724$.

340. Sajotschewsky, W. Wied. Ann. Beib., 3, 74I-3: 2223, 2227.

341. Waage, P. Z. anal. Chem., 18, 417-28: 723 .

\section{0}

342. Avenarius, M. J. Russ. Phys. Chem. Soc., 12, 20-22; Wied. Ann. Beib., 6, 208-9 (1882): 2223. 343. Brühl, J. W. Wied. Ann. Beib., 4, 776-86 (p. 781): 13, 2222, 2261.

344. Destrem, A. C. r. acad. sci. Paris, 90, 1213-15; Ber. chem. Ges., 13, 1355; J. B., 591: 5213, 523. 345. Eder, J. W. Sitzb. Akad. Wiss. Wien, 82, II, 1284-7: 423.

346. Hannay, J. B. and J. Hogarth. Proc. Roy. Soc. London, 30, 178-88: 2223.

347. de Heen, P. Mém. Acad. Roy. Belg., 31, 1-51; Wied. Ann. Beib., 5, 105-7 (1881): 2222, 22221.

348. Hehner, O. Alcohol Tables (1880); Analyst; Z. anal. Chem., 19, 485-90: 73.

349. Jorissen, A. Bull. acad. Belg. (2), 50, 108-10; Ber. chem. Ges., 14, 2439: 615, 625 .

350. Lorenz, L. Wied. Ann., 11, 70-103 (p. 96): 2222, 2261, 2265. 
351. Mann, C. Chem. Ztg., 4, 307: 61115.

352. Noack, K. Diss. Jena: 2225,3225 .

353. Pictet, R. Archiv. sci. phys. nat. Genève (3), 4, 374-7; Wied. Ann. Beib., 5, Ir2 (188I): 32_8, 63121.

354. Prytz, K. Wied. Ann., 11, 104-20 (p. 110): 21, 2122, 2161 .

355. Raoult, F. M. C. r. acad. sci. Paris, 90, 865-8; Ann. chim. phys. (5), 20, 217-26: 3234.

356. Schmidt, J. G. Ber. chem. Ges., 13, 2342-5 (note p. 2343): 6r214.

357. Strauss, O. J. Russ. Phys. Chem. Soc., 12, 207-18; Wied. Ann. Beib., 6, 282-3 (1882): 3223.

358. Tumsky, K. J. Russ. Phys. Chem. Soc., 12, 357; Z. anal. Chem., 21, 576 (1882): 614.

359. Vincent, C. et B. Delachanal. C. r. acad. sci. Paris, 90, 747-50; Bull. soc. chim. (2), 33, 405-10; Ann. chim. phys. (5), 20, 207-17; J. B., 396: 21, 2222, 422.

360. Wartha, V. C. r. acad. sci. Paris, 90, roo8; Z. anal. Chem., 20, 249 (188I): 3235, 75.

361. Weber, H. F. Wied. Ann., 10, 103-29, 304-20 and 472-500 (pp. 105, 313); 11, 347-52: 2232.

362. Zettermann, F. Akad. Afh'g. Helsingfors (1880); J. de phys., 10, 312-6; Wied. Ann. Beib.. 5, 737 (I88I): 21, 2122, 2222, 23, 2322, 31, 3131, 3231, 33, 333I.

\section{1}

363. Ångstrom, K. Öfversigt. Svenska Vet. Ak. För., 6, 37; Wied. Ann., 15, 297-308 (1882): 81.

364. Bedson, P. P. and W. C. Williams. Ber. chem. Ges., 14, 2550-6: 2222, 2261 .

365. Cazeneuve, P. et S. Cotton. Bull. soc. chim. (2), 35, 102-4; Z. anal. Chem., 20, 584: $6 \mathrm{I}$.

366. Cazeneuve, P. et S. Cotton. J. pharm. chim. (5), 2, 361-7; J. Chem. Soc. London Abst., 40, 197-8: 613.

367. Fock, A. H. Stockholm: 73.

368. Gladstone, J. H. and A. Tribe. J. Chem. Soc. London, 39, I-12; 41, 5-18 (r882): 5213.

369. Hartwig, K. Programm kgl. Kreisrealschule zu Nürnberg; Wied. Ann. Beib., 11, roI-2 (1887): $224 I, 324 I$.

370. Jorissen, A. Rep. anal. Chem., 1, I8; Z. anal. Chem., 20, 584: 6, 7 .

371. Konowalow, D. Wied. Ann., 14, 34-52, 219-26: 2227, 3227, 631132 .

372. Naccari, A. e S. Pagliani. Nuov. Cimento (3), 10, 40-58; Att. acc. Torino, 16, 407: 2221, $22211,2227$. 373. Nichols, E. L. and A. W. Wheeler. Phil. Mag. (5), 11, II $3-20: 373$.

374. Pagliani, S. Atti. Inst. Venezia., 7, I389-1410 (1880-I); Nuov. Cimento, 12, 229-44 (1882): 3222, 3231 . 375. Pictet, R. Archiv. sci. phys. nat. Genève (3), 6, 236-8; Wied. Ann. Beib., 6, 220 (1882): 63121, 87.

376. Reis, M. A. von. Wied. Ann., 13, 447-65 (pp. 451, 452): $2211,2231$.

377. Schmidt, J. G. Ber. chem. Ges., 14, 1848-51: 61214.

378. Shuk, K. J. Russ. Phys. Chem. Soc., 13, 239, 44I; Fortschr. Phys. 755: 22221.

\section{2}

379. Cazeneuve, P. J. pharm. chim. (5), 5, 494-8; J. Chem. Soc. London Abst., 42, 1002: 613, 623.

380. Dahm, G. Z. anal. Chem., 21, 485-95: 73 .

381. Destrem, A. Ann. chim. phys. (5), 27, I-73 (pp. I3, 23); Ber. chem. Ges., 16, 226-9 (1883); J. B., 642: 5213,523 .

382. Diaconoff, M. Bull. soc. chim. (2), 38, 172: 23, 233I, 2337.

383. Foerster, K. Ber. chem. Ges., 15, 230-2; Z. anal. Chem., 22, 258 (1883): 6 i5.

384. Haas, B. Mitt. Versuchsstation Kloster Neuberg, 1, 33: 3228.

385. Klep1, A. J. prak. Chem. N. F., 25, 526; J. Soc. Chem. Ind. Abst., 1, 5 I6: 41, 413, 423.

386. Ladenburg, A. Breslau, Handwörterbuch der Chemie; Engler, pp. 445-464, Alkohol-Fabrikation und Alkoholometrie: $I I, I 5,7 I$.

387. Lenz, R. MIém. acad. Petersburg (7), 30, 64 pp.; Wied. Ann. Beib., 7, 399-406 (I883): 224I, 324I.

388. Lossen, W. Lieb. Ann., 214, 81-137: 23, 2322, 25, 2522.

389. Marquardt, L. Ber. chem. Ges., 15, 1370-3, 1661-5: 625 .

390. Nadejdine, A. J. Russ. Phys. Chem. Soc., 14, 157-62, 536-42; 15, 25-30 (1883); Wied. Ann. Beib., 7, 678-8I (1883); J. Russ. Phys. Chem. Soc., 16, 222 (I884); Exner's Rep., 20, 446 (1884); 23, 6I 7, 685 (1887): 2223 .

391. Pagliani, S. and A. Emo. Atti. Acc. Sci. Torino, 18, 67-73; Wied. Ann. Beib., 8, 18 (1884): 421 .

392. Pawlewski, B. Ber. chem. Ges., 15, 460-2; 16, 2633-6 (1883): 2223.

393. Schiff, R. Ber. chem. Ges., 15, 2965-75; Lieb. Ann., 223, 47 (1883): 2221, 2222, 2225.

394. Stephan, C. Wied. Ann., 17, 673-701: 2226, 2241, 3226, 3241 .

395. Steudel, V. Wied. Ann., 16, 369-94 (p. 374): 21, 2126, 2226, 23, 2326.

396. Thomas, A. Paris: $7 I$.

397. Tollens, B. Ber. chem. Ges., 15, I635-9: 6r211.

398. Tollens, B. Ber. chem. Ges., 15, 1828-30: 6r2II.

399. Brennerei Ztg., 11, r65: 631 . 
400. Drecker, J. Wied. Ann., 20, 870-96: 2222, 2222I, 3222, 32221 .

401. Gal, H. Bull. soc. chim. (2), 39, 6-10, 393: 2224, 2227, 3224, 3227.

402. Gladstone, J. H., and A. Tribe. J. Chem. Soc. London, 43, 346; Z. anal. Chem., 23, 425 (1884): 614.

403. Graetz, L. Wied. Ann., 18, 79-94 (p. 92); 25, 337-57 (1885); Exner's Repert, 21, 733 (1885): 2232.

404. Jarolimek, A. Monatsh., 4, 193-202 (p. 199): 2223, 2227.

405. Johst, W. Wied. Ann., 20,47-62 (p. 56): $2222,2265$.

406. Kahlbaum, G. W. A. Ber. chem. Ges., 16, $2476-84$ (p. 2480$) ; 17$, I245-62, I263-72 (I884); 18,3146 (1885): 2233.

407. Möller, J. Monograph, Berlin: II.

408. Nasini, R. Gazz. chim. ital., 13, I20-I7I (p. I35); Wied. Ann. Beib., 7, 392-5: 2222, 2265.

409. Pagliani, S., und L. Palazzo. Mem. R. Acc. Lincei. (3), 19, 279; Wied. Ann. Beib., 9, 149-52 (1885): 22222.

410. Penzoldt, F., und E. Fischer. Ber. chem. Ges., 16, 657-8: 61215.

411. Quincke, G. Wied. Ann., 19, 40I-35: 2222, 22222, 2261.

412. Schall, C. Ber. chem. Ges., 16, 30II; 17, 1044-58, 2199-22II (I884) (p. 2205): 221 I, 2227.

413. Schiff, R. Gazz. chim. ital., 13, I77-248; Lieb. Ann., 220, 7I-113 (p. 100): 2221, 2222, $6311 I I, 63 I I 32$.

414. Sieben, G. Ber. d. Oberhess. Ges. Nat. u. Heilkunde, 23, 140-79 (pp. 148, 17I): $2222,2261,2265$.

415. Vyere, - van de. Arch. Pharm., 221, 870: 613.

416. Wroblewski, S. von, und K. Olzewski. Monatsh., 4, 337-8; Repert. Physik., 19, 494 (I883); C. r. acad. sci. Paris, 96, II40-2, I225-6: 2234.

\section{4}

417. Avenarius, M. J. Russ. Phys. Chem. Soc., 16, 242-7; Kiew. Nachr., 249-57; Wied. Ann. Beib., 8; 806: 22221 .

418. Bartoli, A. l'Orosi, 7, 3; Wied. Ann. Beib., 8, 71 2: 23, 2341.

419. Bartoli, A. l'Orosi, 7, 233-6; Wied. Ann. Beib., 9, 44 (1885): 23, 2341.

420. Bartoli, A., und E. Stracciati. Nuov. Cimento. (3), 16, $91-104$; Wied. Ann. Beib.,9, 5I0-I ( $\left.188_{5}\right): 22221$.

421. Blïmcke, A. Wied. Ann., 23, 404-I 5: 22223, 81 .

422. Crismer, L. Ber. chem. Ges., 17, 649-52: 6ri23.

423. Davy, E. W. Chem. News., 50, 200; Z. anal. Chem., 24, 260 (I885): 614.

424. Gladstone, J. H. J. Chem. Soc. London, 45, 24I-59 (p. 245): 21, 2122, $2161,2165,23,25$.

425. Guthrie, F. Phil. Mag. (5), 18, 495-51 7: 32225, 3239.

426. de Heen, P. Bull. acad. Belg. (3), 7, 210-8: 2223, 2231, 2237.

427. de Heen, P. Bull. acad. Belg. (3), 7, 248-52; (3), 9, 251-5 (1885); Wied. Ann. Beib., 8, $462: 2226,2227$.

428. Lunge, G., V. Meyer und E. Schulze. Bern; C. B., 854; J. Chem. Soc. London Abst. 48, 708 (1885); Vierteljahrschrift Fortschr. Chem. d. Nahrungsmittel I (I886); Sonderschrift, Berlin (I886), J. Springer: $6,615,625,635$.

429. Mendeléef, D. J. Russ. Phys. Chem. Soc., 16, I-10, 282-9r; Wied. Ann. Beib., 8, 806: $22221,2223$.

430. Pagliani, S. e L. Palazzo. Atti. R. Acc. Sci. Torino, 19, $763-82 ; 20,54$ ( 1885 ); Wied. Ann. Beib., 8 , 795-6; J. de phys. (2), 4, 371 (I885): 32222 .

431. Perkin, W. H. J. Chem. Soc. London, 45, 42I-580 (p. 465); J. prak. Chem. N. F., 31, 488, 505 (I885); I3, 2222, 2253, 631145.

432. Skalweit, J. Repert. anal. Chem., 4, 32I-6. 2261, 326 , 624 .

*433. Squibb, Messrs. E. R., E. H. and C. F. Ephemeris, 2, 522, Absolute Alcohol; Chem. News., 51, 7, 2I, 33 (I885); Z. anal. Chem., 26, 94-5 (I885); J. B., (I885) II60; Z. Spiritusind., 7, 889 (I884); Apoth. Ztg., 5, 725 (1885): 2222, 3222, 6311II, 631132, 73, 83.

434. Squibb, Messrs. E. R., E.H. and C. F. Ephemeris, 2; Chem. News., 51, 66-9, 76-8, 94; Z. anal. Chem., $26,96-7(1887): 521,636,73,8$.

435. Vicentini, G. Mem. R. acc. Torino (2), 36, 22; Wied. Ann. Beib., 9, I3I (I885): 2241.

436. Winkelmann, A. Wied. Ann., 23, 203-27 (pp. 218-219): 2224.

437. Zander, A. Lieb. Ann., 224, $56-95$ (p. 78): $21,2122,21221,23,25$.

\section{5}

438. Bartoli, A. und E. Stracciati. Nuov. Cimento (3), 18, III-4; Wied. Ann. Beib., 10, 339 (I886); 2222, $22221,3222,32221$.

439. Begou, F. Treatise: $7 T$.

440. Blümcke, A. Wied. Ann., 25, I54-65: 3231 .

441. Brannt, W. T. Treatise, Philadelphia: $I I, 6,87$.

442. Dufet, H. Bull. soc. minér, 8, 300: 2261 . 
443. Fo1sssereau, G. C. r. acad. sci. Paris, 101, 243-5; J. de phys. (2), 4, 450-6: 224I, 61125.

444. Fremy. Encyclopädie chimique, Tome VI, ${ }_{5} 5^{-1} 37$ (p. 26), Anhydrous Alcohol; (p. 29) Alcoholometry; (p. I33) Bibliography: $I I, 7 I, 88$.

*445. Gerlach, G. Th. Z. anal. Chem., 24, 487-533.

(p. 490): 2222, 22221, 2227, 2231, 2233, 3222, 32221, 3227, 3231, 3233.

446. de Heen, P. Bull. acad. Belg. (3), 9, 550-6x: 22222.

447. Ilges, R. Z. Spiritusind, 8, II4-9: 3228, 3231, 3233.

448. Kahlbaum, G. W. A. Monograph, Leipzig: 2233.

449. Kanonnikoff, J. J. prak. Chem. N. F., 31, 32I; 32, 497 (1885): 2222, 226I, 2265.

450. Laval, E. Mém. soc. sci. Bordeaux (3), 2, 37-62 (p. 44, 49): 2237, 3237.

451. Magie, W. F. Diss. Berlin; Wied. Ann., 25, 421-37 (1885): 2225.

452. Morley, E. W. Z. anal. Chem., 24, 533-42: 85 .

453. Pagliani, S., and A. Batelli. Atti. d. R. Acc. Torino., 20,607, 845; Ann. Roy. Inst. Tecnico. Torino. 13 (1884-5); Wied. Ann. Beib. 10, 222-5 (1886): 2222, 2226.

454. Pfeiffer, E. Wied. Ann., 25, 232-45: 324I.

455. Pfeiffer, E. Wied. Ann., 26, $31-44: 224 I, 631132$.

456. Pfeiffer, E. Wied. Ann., 26, 226-39: 224I.

457. Quincke, G. Wied. Ann., 24, 347-416, 606-18 (p. 363, 386, 395, 614): 21, 2122, 2153, 2222, 2253.

458. Ramsay, W. and S. Young. Proc. Roy. Soc. London, 38, 329-30; Phil. Trans., 177, I, 123-56 (1886) $2221,2223$.

459. Regnault, J. et Villejean. Ann. chim. phys. (6), 4, 430-2: 6 .

460. Traube, J. J. prak. Chem. N. F., 31, 177-218: 3225,724 .

461. Traube, J. J. prak. Chem. N. F., 31, 514-27 (p. 518): 3225.

462. Winkelmann, A. Wied. Ann., 26, 105-34: 2222, 2224, 2233.

463. Worthington, A. M. Phil. Mag. (5), 20, 5 I (p. 59): 2213, 2222, 2225.

\section{6}

464. Alexejew, W. Wied. Ann., 28, 305-38: 61123, 8.

465. Arzberger. Normal Eich.-Komm. Wien: 73.

466. Bartoli, A. Atti R. Acc. Lincei (4), 2, 122-9; Wied. Ann. Beib., 11, 159-60 (1887): 2241, 422.

467. Deiniger, H. Monograph, Berlin: 6,87.

468. Deluc, Paris. Recherches sur les modifications de l'atmosphère, Tome I, p. 219: 2222, 22221.

469. Lubarsch, O. Diss. Halle; Wied. Ann., 37, 524-5 (1889): 32223, 421.

470. Magie, W. F. Am. J. Sci. (3), 31, 189-93: 2225.

471. Müller-Erzbach, W. Ber. chem. Ges., 19, 127-8: 63114.

472. Neyreneuf, M. Ann. chim. phys. (6), $9,535^{-53}$ (p. 546): 2271 .

473. Noack, K. Wied. Ann., 27, 289-300: 2226, 3226.

474. Norm. Eich.-Komm. Berlin, Mitth., 1, 28 (Oct.): 72.

475. Perkin, W. H. J. Chem. Soc. London, 49, 777-90: 3253 .

476. Reynolds, O. Phil. Trans., 177, 157-234: 2226.

477. Richardson, A. J. Chem. Soc. London, 49, 761-76: 2227,631111 .

478. Stohmann, F. J. prak. Chem. N. F., 32, 420-4; J. Chem. Soc. London, Abst., 50, 295: 2239.

479. Traube, J. J. prak. Chem. N. F., 34, 292-31 I, 515-38: 2225.

480. Traube, J. Ber. chem. Ges., 19, 871-92: 2225, 2226, 3225, 3226.

481. Traube, J. Ber. chem. Ges., 19, 892-6: 2225, 2226, 625 .

482. Traube, J. Ber. chem. Ges., 19, 1679-82: 2225.

*483. Windisch, W. Z. Spiritusind., 9, 519; Chem. Rep., 11, 24 (1887); Z. anal. Chem., 27, 514 (I888): 61213,63213 .

\section{7}

484. Amagat, E. H. C. r. acad. sci. Paris, 105, II 20-2; Z.physik. Chem., 2, 246 (I888): 22221, 82.

485. Arnaud, A. Diss. Montpelier: $7 x$.

486. Blümcke, A. Wied. Ann., 30, 243-50: 2222, 421 .

487. Conradi, H. Berlin: 73 .

488. Crafts, J. M. Ber. chem. Ges., 20, 709-16 (p. 712): 2233.

489. Eidgenossische Eichstatte. Bern: 73 .

490. Fitzgerald, G. F. Proc. Roy. Soc. London, 42, 216-24; Wied. Ann. Beib., 12, 33-4 (1888): 2223.

491. Fitzpatrick, T. C. Phil. Mag. (5), 24, 377-9r: 2241, 2242.

492. Flawitzky, F. Ber. chem. Ges., 20, 1948-55: $13,21,2233,23$.

*493. Gayon, U. C. r. acad. sci. Paris, 105, r182-3; Bull. soc. chim. (2), 49, 67-8 (1888); J. Soc. Chem. Ind., 7, 238 (IS88); Z. angew. Chem., 1, 85 (I888); Chem. Rep., 12, 5 (1888): 61214, 622.

494. Hehner, O. Analyst, 12, 25-9: 613, 623. 
495. Isambert, M. Ann. chim. phys. (6), 12, 538-52 (p. 550): 22222, $42 I$.

496. Kablukow, I. J. Russ. Phys. Chem. Soc., 19, г78; Fortsch. Phys., 1, 489: 22221, 2225.

497. Malepeyre, F., et A. Petit. Treatise, Paris: 72,73 .

498. Mendeléeff, D. J. Chem. Soc. London, 51, 778-82: 321, 3222, 422.

499. Mendeléeff, D. Z. physik. Chem., 1, 273-84: 321, 3222, 422.

500. Mendeléeff, D. Monograph, St. Petersburg (pp. 248-310, 492-6): 321, 3222, 422.

501. Norm. Eich.-Komm. Berlin, Mitth., 1, 62 (Dec.): 7.

502. van der Plaats, J. D. Rec. trav. chim., 6, 45-59; Wied. Ann. Beib., 11, 798 (1887): 85.

503. Ramsay, W., and S. Young. Phil. Trans., 178, A, 57-93: 223.

504. Ramsay, W., and S. Young. Phil. Trans., 178, A, 313-34: $21,213$.

505. Ramsay, W., and S. Young. Phil. Mag. (5), 24, I96-2I2 (p. 200): 2223.

506. Ramsay, W., and S. Young. Chem. News., 56, I8; Wied. Ann. Beib., 12, 36 (I888): 223.

507. Ramsay, W., und S. Young. Z. physik. Chem., 1, 237-58: 2213, 2227.

508. Tammann, G. Wied. Ann., 32, 683-99 (p. 695): 2227, 61125 .

509. Timberg, G. Wied. Ann., 30, 545-6I (pp. 549, 553, 560): 2225.

510. Traube, J. Ber. chem. Ges., 20, 2644, 2825, 2829, 2831; Z. anal. Chem., 27, 655-6I (1888): 6212, 625, 725 . 511. Willmers. Acta. Univers. Lundensis, 24, I: $3 I, 3 I 27$.

\section{8}

*512. Ångström, K. Wied. Ann., 33, 223-33 (p. 232); J. B., 204: 2222, 22223.

513. Beckmann, E. Z. physik. Chem., 2, 715-43 (pp. 728, 732): 426.

514. Bois aus Haag, H. E. J. G. du Wied. Ann., 35, 137-67 (p. 163): 2252.

*515. Clarke, F. W. Tables, Smithsonian Institution, Washington, Constants of Nature: Part I, A Table of Specific Gravity for Solids and Liquids: 88

516. Derham, B. J. Soc. Chem. Ind., 7, 276-86: 74.

517. Dittmar, W. and C. Fawsitt Trans. Roy. Soc. Edin., 33, 509-34; Chem. Rep., 12, 14I; J. Chem. Soc. London, Abst., 56, 578 (1889); Z. anal. Chem., 29, 82-5 (1890): 21, 2122, 3122.

518. Elsworthy, H. S. J. Chem. Soc. London, 53, 102-4; Chem. News, 56, 236 (1887): 724.

519. Fock, A. Z. physik. Chem., 2, 296-305: 72r.

520. Girard, C. et X. Rocques C. r. acad. sci. Paris, 107, II 58; Chem. Rep., 13, I6 (1889): 624.

521. Godefroy, L. Treatise, Paris: 15,6 .

522. Godefroy, L. C. r. acad. sci. Paris, 106, Ior8-20; Z. angew. Chem., 1, 274; Chem. Rep., 12, 107: 612, 615.

523. Göttig, Chr. Ber. chem. Ges., 21, 56I-5: 51, 511 .

524. Haas, B. Mitt. Versuchsstation Kloster Neuberg, 5, 66: 73.

525. Habermann, J. Verh. d. Naturf. Ver. Brünn; Z. angew. Chem., 1, 450; J. B., 26I4: 6I3.

526. Habermann, J. Z. anal. Chem., 27, 663; Chem. Rep., 12, гог: $631132,87$.

527. Hartwig, K. Wied. Ann., 33, 58-80; 43, 839-40 (I89I): 2222, 22221, 2241.

528. de Heen, P. et F. Deruyts Bull. acad. Belg. (3), 15, I68-9I (p. 183): $223 I$.

529. Henrichson, S. Wied. Ann., 34, I80-22I (p. 183): 225.

530. Huber, E. Am. J. Pharm., I 29; Chem. Rep., 12, I23: 6.

531. Ketteler, E. Wied. Ann., 33, 506-34 (pp. 520-521): 2222, 2233, 226r, 2265.

532. Magie, W. F. Phil. Mag. (5), 26, 162-83: 2225.

533. Martini, T. Atti. R. Inst. Venet. (6), 6, —; Wied. Ann. Beib., 12, 566-9: 2272.

534. Morley, E. W. Z. anal. Chem., 27, 1-7: 85.

535. Morse, H. N. and W. M. Burton. Am. Chem. J., 10, 154; Z. Anal. Chem., 28, 240-2 (1889): 521.

536. Norm. Eich.-Komm. Berlin, Mitth., 1, 84 (June): 72 .

537. Norm. Eich.-Komm. Berlin, Mitth., 1, ror, (Dec.): 73.

538. Norm. Eich.-Komm. Tafeln, Berlin: 73.

539. Pampe, F. Muspratt's Chemie I, p. 365, Alkohol: 3228 .

540. Raoul, F. M. C. r. acad. sci. Paris, 107, 442-5: $2227,42$.

541. Reid, A. F. Chem. News, 57, 39: 724.

542. Rocques, X. C. r. acad. sci. Paris, 106, I296; Chem. Rep., 12, I28: 6, 6r, 63.

543. Röse, B. Z. angew. Chem., 1, 31-5; Chem. Rep., 12, 52-3: 7 .

544. Roux, J. P. Treatise, Paris : $15,6,87$.

545. Sell. Arb. des Reichsgesundheits-amt., 4, I58: 6.

546. Stevenson, T. Treatise, London: $I I, 71,73$.

547. Stohmann, F. und Bruno Kerl. Encyklopädisches Handbuch der Technischen Chemie. Muspratt's Chemie, 4te Auflage, Band I, 298-702 Alkohol und Alkoholometrie: $I I, 7 I$.

548. Sutherland, W. Phil. Mag. (5), 26, 298-305 (p. 30I): 2231.

549. Weilenmann, A. Schr. Nat. Ges. Zürich., 33, 37-56; Exner Rep. Physik., 24, 66o; Wied. Ann. Beib., 12, 766: 2222, 22221 .

550. Windisch, C. Z. Spiritusind., 11, 348; Chem. Rep., 12, 323-4: 625. 


\section{9}

551. Baille, J. B. and C. Fëry. Ann. chim. phys. (6), 17, 246-56: 86 .

552. Barbet, E. J. pharm. chim. (5), 19, 41 $3-6,457-60$; Pharm. Ztg. 34, $48 \mathrm{r}$ : $6 \mathrm{r}$.

553. Bellati, E. M. et P. Lussana. Att. inst. Venet. (6), 7, 1169; J. de phys. (2), 9, 300 (1890); Wied. Ann. Beib., 14, 18 (1890): 2222, 2225, 421.

554. Bornträger, H. Z. anal. Chem., 28, 60-2; J. Chem. Soc., London, Abst., 56, 552; Chem. Rep., 13, 27 : $6 \mathrm{~T}, 612 T, 615$.

555. Bourcart. R. Bull. soc. ind. de Mulhouse, 558; Chem. Rep , 14, 29 (1890); Z. anal. Chem., 29, 608-9 (1890): 624 .

556. Cazeneuve, P. J. pharm. chim. (5), 19, 513; Chem. Rep., 13, I98: 6rarr.

557. Crismer, L. Chem. Rep., 13, I98: 6r2I.

558. D'Arcy, R. F. Phil. Mag. (5), 28, 221-31; Z. physik. Chem. Ref. 4, 589; Wied. Ann. Bei.b, 14, 247 (1890): 3226 .

559. Henneberg, H. Wied. Ann., 36, 146-64: 3232

*560. Homann, H. Treatise, Berlin (k. Norm. Eich-Komm.): 721.

561. Jaeger, W. Wied. Ann., 36, 165-213 (pp. 180, 190): 2221, 2271.

562. Kablukoff, I. Z. physik. Chem., 4, 429-34: 224I.

563. Le Blanc, M. Z. physik. Chem., 4, 553-60 (p. 555): $21,2122,2161,2222,2261$.

564. Müller, O. Wied. Ann., 37, 24-43: 2222, 2222I, 421 .

565. Norm. Eich.-Komm. Berlin, Mitth., 1, 119 (Apr.): 72.

566. Pagliani, S. Rend. R. Acc. Lincei. (4), 5, I, 777-85: Wied. Ann. Beib., 14, 93-5 (1890): 22222, 32222

567. Pagliani, S. Rend. R. Acc. Lincei. (4), 5, II, 685-892: 22222, 2227, 2231.

568. Pfeiffer, E. Wied. Ann., 37, 539: 2241, 226r.

569. Pulfrich, C. Z. physik. Chem., 4, 561 669 (p. 567): $326 \mathrm{I}$.

570. Ramsay, W. J. Chem. Soc. London, $55,521-36$ (p. 53I):8j

571. Robinet, É. Treatise, Paris: 15 .

572. Stohmann, F. J. prak. Chem. N. F., 40, 343-64: 21, 2139 .

573. Tereschin, S. Wied. Ann., 36. 792-804 (p. 799): 2245.

574. Traube, J. Z. anal. Chem., 28, 26; Chem. Rep., 13, 27: 625, 724.

575. Udranzky, L. von. Rev. intern. fals., 2, I88; Chem. Rep., 13, 200: 6rs.

576. Waller, E. J. Am. Chem. Soc., 11, 124; Chem. Rep., 14, 23 (I890); Chem. News, 61, 53-4 (I890) J. Chem. Soc. London, 58, 727 (1890); $Z$. anal. Chem., 30, $12-3$ (1891): 6, 632113.

*577. Weinstein, B. Kais. Norm. Eich-Komm. Metro. Beit., 6: 721 .

\section{0}

578. Barbiet, P. et L. Roux. Bull. soc. chim. (3), 4, 9-16: 2222, 2265.

579. Barus, C. Am. J.Sci. (3), 38, 407 (1889); (3), 39, 478-51r; (p. 489, 500, 502); Bull. United States Geol Survey No. 92 and No. $96: 2222,2223$.

580. Beckmann, E. Z. physik. Chem., 6, 432-73 (p. 472): 222I, 2222, 2233.

581. Buchkremer, L. Diss. Bonn; Z. physik. Chem., 6, 161-86 (p. 174): 2222, 226r, 32224.

582. Deventer, C. M. und L. T. Reicher. Z. physik. Chem., 5, 177-80; 8, 536-42 (1891): 423.

583. Farrington, T. Chem. News, 61, 208: 3222, 326r.

584. Gartenmeister, R. Z. physik. Chem., 6, 524-5I (p. 529): 13, 2222, 2226.

585. Guldberg, C. M. Z. physik. Chem., 5, 374-82: 2213, 2222, 2233.

586. Ihl, A. Chem. Ztg., 14, I571: 6121 .

587. Itallie, L. von. Apoth. Ztg., 5, 687; Chem. Rep., 14, 317: 6r.

588. Korten, M. Diss. Bonn; Wied. Ann. Beib., 14, 769-72: 2222, $225 I$.

589. Krïmmel. Berlin: 722 .

590. Müller, O. F. Z. angew. Chem., 3, 634-6: 6r214.

*591. Norm. Eich.-Komm. Berlin Mitth., 1, I52 (Mch.): 721, 3225.

592. Norm. Eich.-Komm. Berlin 2te auflage: 7 .

593. Pagliani, S. Nuov. Cimento. (3), 27, 209; J. de phys. (2), 1C, $5_{89}$ (189r): 32222.

594. Pickering, S. U. Z. physik. Chem., 6, 10-5: $321,42$.

595. Possanner, B. von. Tabellen, Wien, Alkoholometrisch-Reductions Tabellen: 73.

596. Raoul, F. M. Ann. chim. phys. (6), 20, 297-37I (p. 346): 3227.

597. Soret, J. L. et A. Rilliet. C. r. acad. sci. Paris, 110, 137; Z. anal. Chem., 31, 328 (1892): 2263.

598. Stutzer, A. und O. Reitmair. Z. angew. Chem., 3, 522-31; Chem. Rep., 14, 278 ; J. Chem. Soc. I.ondon Abst., 60, 622 (1891): 625.

599. Timofejew, W. Z. physik. Chem., 6, I4I-52: 421 .

599a. Turbaba, D. Verh. phys. chem. Abt. Ges. exper. Wiss. Charkow., 18, 8-10; Fortschr. Phys., 46. II, 2I4; Verh. ibid., 21, 315 ( 1893 ): $21,21221,23,23221$.

600. Winkelmann, A. Wied. Ann., 39, I-I 5: 33, 3328.

601. Wirtz, K. Wied. Ann., 40, 438-49 (p. 446): 2237.

$$
77398^{\circ}-\mathrm{r} 3-9
$$


602. Berthelot, M. Ann. chim. phys. (6), 469-75: 12 .

603. Bodländer, G. Z. physik. Chem., 7, 308-22: 423 .

604. Bornträger, H. Z. anal. Chem., 30, 208; J. Chem. Soc. London, Abst., 58, 669 (1890); Chem. Rep., 15, I04: 6I214.

605. Brodman, C. Diss. Göttingen; Wied. Ann., 45, 159-84 (1892) (p. 182): 2226.

606. Gossart, E. C. r. acad. sci. Paris, 113, 537-40: 2225, 62125 .

607. Heilborn, E. Z. physik. Chem., 7, 367 77: 22221.

608. Jäger, G. Sitzb. Akad. Wiss. Wien., 100, IIa, I233-8 (p. 1236): 2212.

609. Jahn, H. Wied. Ann., 43, 280-305 (p. 283): 21, 2122, 2161, 2165, 2153, 2222, 2253, 2261, '2265.

610. Kablukow, J. J. Russ. Phys. Chem. Soc., 23, I, I and I388-9I; Wied. Ann. Beib., 15, 748: 3227, 423.

611. Kablukow, J. J. Russ. Phys. Chem. Soc., 23, I, 39I-422; Wied. Ann. Beib., 15, 775-6: 324I.

612. Kablukow, J. und A. Zacconi. Diss. Petersburg; Ber. chem. Ges. Ref., 25, 499 (1892): 3273.

613. Lorenz, N. von. Z. gesamt. Brauwesen, 50I; Z. anal. Chem., 31, 335-46 (1892): 624, 7.

*614. Marek, W. Wied. Ann., 44, 171-2 (p. 172): 82 .

615. Mohler, E. Ann. chim. phys. (6), 23, 121-44; Z. anal. Chem., 31, 583-8 (1892): 62, 7 .

616. Müller, J. Diss. Èrlangen; Wied. Ann., 43, 554-67: 2224, 421.

*617. Norm. Eich.-Komm. Berlin, Mitth., 1, 167 (Mch.): 721.

618. Pickering, S. U. Ber. chem. Ges., 24, 1579-91: 2213, 42.

619. Röntgen, W. C. Wied. Ann., 44, 1-23 (p. 22): 22222.

620. Röntgen, W. C. und L. Zehnder. Wied Ann., 44, 24-5I (p. 37): 2I, 2I6I, 2261.

621. Rosa, E. B. Phil. Mag. (5), 31, 188-207; J. B. (1890), 268: 2245.

622. Schall, C. und L. Kossakowsky. Z. physik. Chem., 8, 24I-7I (pp. 256, 267-8): 21, 2122, 2133, $2222,2233$. *623. Scheel, K. Diss. Berlin; Wied. Ann. Beib., 15, 263: 81 .

624. Schmidt, G. C. Z. physik. Chem., 8, 628-46 (p. 633); Chem. Rep., 16, 97 (1892); Lieb. Ann., 266, 266: 2227,631132 .

625. Schumann, W. A. Wied. Ann., 43, 101-25 (p. 102): 86.

626. Schwicker, A. Chem. Ztg., 15, 914: 618 .

627. Tavildarof, N. J. Diss. Petersburg: 6,87 .

628. Timofejew, W. C. r. acad. sci. Paris, 112, 1223-5: 223, 423.

629. Traube, J. Lieb. Ann., 265, 27: 2225.

630. Vernon, H. M. Phil. Mag. (5), 31, 387-92: $8 I$.

*631. Weinstein, B. Z. physik. Chem., 7, 7r: 721 .

\section{2}

632. Arrhenius, S. Z. physik. Chem., 9, 487-511: 324I, 3242.

633. Bardy, C. C. r. acad. sci. Paris, 114, 1201-4; Chem. Rep., 16, 197; Bull. soc. chim. (3), 7, 685: 615.

634. Barillot, E. C. r. acad. sci. Paris, 115, I315-6; Chem. Rep., 17, 7 (I893): 61, 62 .

635. Benedikt, R. und J. Neudörfer. Chem. Ztg., 16, 77-8: 52II.

636. Berthelot, M. et Matignon. Ann. chim. phys. (6), 27, 310-19 (p. 3II): 2239.

637. Cattaneo, C. Atti. R. Acc. Sci., Torino, 28, 329-43; Wied. Ann. Beib., 18, $219-20$ (1894): 2241.

638. Chappuis, P. Arch. sci. phys. nat. Genève (3), 28, 293 (p. 301 ): 82.

639. Coppet, L. de C. r. acad. sci. Paris, 115, 652-3: 3222, 32221 .

640. Delaunay, A. Treatise, Paris: 72.

641. Ferraro, A. Staz. sperim. agrar. ital., 23, 421; J. B. 2570:'

642. Gerber, O. Diss. Jena; Fortschr. Phys. I, 166: 33, 3328.

643. Handl, A. und R. Pribram. Z. physik. Chem., 9, 529-39: 13, 2226.

644. Jäger, G. Sitzb. Akad. Wiss. W ien., 101, IIa, I58-70 (p. I6I): 2225, 3225.

*645. Kreitling, W. Diss. Erlangen: 2222, 22221, 3222, 32221, 73.

646. Landolt, H. und H. Jahn Z. physik. Chem., 10, 289-320 (pp. 316, 317): 2122, 2161, 2165, 2222, $2261,2262$. 647. Liebetanz, P. Diss. Breslau; Fortschr. Phys., 48, II, 358: 3237, 3230.

648. Lobry de Bruyn, C. A. Rec. trav. chim., 11, 112-56; Z. physik. Chem., 10, 782-9; Chem. Rep., 17, 26 (I893): $41,413,423$.

649. Paschkow. Diss. Charkow: 2I, 214I, 224I, 23, 234I.

650. Tumlirz, O. Sitzb. Akad. Wiss. Wien., 101, IIa, 129-34; Wied. Ann. Beib., 16, 660: 2237.

651. Völlmer, B. Diss. Halle; Wied. Ann., 52, 328-56 (I894): 21, 2141, 2222, 2241, 631132.

652. Young, S. Phil. Mag. (5), 34, 5 10-15 (p. 512 ): 2223.

653. — Z. anal. Chem., 31, 98-9: 61, 62. 
654. Amagat, E. H. Ann. chim. phys. (6), 29, 68-136, 505-74: 22222, 2223.

655. Bèla von Bitt6 Chem. Ztg., 17, 611: 613, 614, 615.

656. Bell, J. C. J. Soc. Chem. Ind., 12, 236; Chem. Rep., 17, 122: 6.

657. Cattaneo, C. Rend. R. Acc. dei Lincei (5), 2, I, 295-8; Wied. Ann. Beib., 17, 1085-6: 224I.

658. Cattane0, C. Rend. R. Acc. dei Lincei (5), 2, II, II2-9; Wied. Ann. Beib., 18, 365 (1894): 224 I.

659. Eykmann, J. F. Rec. trav. chim., 12, I57-97 (p. 169): 2222, 2261.

660. Galopin, P. Diss. Genève; Wied. Ann. Beib., 18, 649 (1894): 2234, 63123.

661. Gernhardt, V. Diss. Erlangen; Fortschr. Phys., II, 378: 23, 2337, 435.

662. Hall, T. P. Phil. Mag. (5), 36, 385-413: 2225.

663. Holland, R. J. Wied. Ann., 50, 261-92: 3I, 3141, 324I.

664. Jahn, H. Z. physik. Chem., 11, 787-93 (p. 790): 2237.

665. Kahlbaum, G. W. A. Monograph, Basel: 2227.

666. Landolt, H. Z. physik. Chem., 11, $633-44$ (p. 635): 2I, 2127 .

667. Lang. Vers. Ver. schweiz. anal. Chemiker; Chem. Ztg., 17, 1524, 1543-4: 6 I.

668. Lobry de Bruyn, C. A. Ber. chem. Ges., 26, 268-74: II, $21,22$.

669. Norm. Eich.-Komm. Berlin, Mitth., 1, 286 (Aug.): 72.

670. Pařizek, A. P. and O. Šulc. Ber. chem. Ges., 26, I408-12: 2233.

671. Pickering, S. U. J. Chem. Soc. London, 63, 998-1027 (p. 1015): 3, 42.

672. Ramsay, W. and J. Shields. Phil. Trans. 184, A. 647-73: 2213, 2225.

673. Ramsay, W. und J. S. Shields. J. Chem. Soc. London, 63, 1089-1 109; Z. physik. Chem., 12, 433-75 (pp. 457, 467): 2213, 2225 .

674. Rosmanit, L. F. and S. F. Drenovski. Treatise, Kiev: 6,87 .

675. Scarisbrick, J. J. Soc. Chem. Ind., 12, 893-901: 6212, 7 .

676. Schönrock, O. Z. physik. Chem., 11, 753-86 (p. 761): 2253.

677. von Smoluchowski, M. Sitzb. Akad. Wiss. Wien (2), 102, 2a, 11 16-40: 2226.

678. Sorel, E. C. r. acad. sci. Paris, 116, 693-5:3228, 87 .

*679. Squibb, E. R. J. Am. Chem. Soc., 15, 126-40, Absolute Alcohol; C. B. (1894) II, 47I; J. B., 646: 2222, 63IIIT, 631I32.

680. Tammann, G. Z. physik. Chem., 11, 676-92 (pp. 685, 688): 22222.

681. Verschaffelt, J. Bull. acad. Belg. (3), 26, 707; (3), 27, 49-84 (1894) (pp. 52, 78, 80): 3261 .

682. Villon, A. M. Bull. soc. chim. (3), 9, 639; Chem. Rep., 17, 231: 6, 63 .

683. Wakeman, A. J. Z. physik. Chem., 11, 49-74: 3242, 3243, 3244, 3273.

*684. Windisch, $\mathrm{K}$. Arbeiten aus kais. Gesundheitsamte, 9, 75 pp.; 2222, 2222I, 3222, 3222I, 73.

*685. Windisch, K. Tables, Berlin; Z. angew. Chem., 6, 308: 73.

\section{4}

686. Abegg, R. Z. physik. Chem., 15, 209-6I (p. 217): 3234

687. Ashby, A. Analyst, 19, 265-73: 623 .

688. Barbet, E. Treatise, Paris: $7 I$.

689. Campetti, A. Nuov. Cimento (3), 35, 225-34; Wied. Ann. Beib., 18, 942: 2243.

690. Carrara, G. Gazz. chim. ital., 24, II, 504-35: 2242, 2244.

691. Deventer, C. M. van und E. Cohen. Z. physik. Chem., 14, 124-8: 423.

692. Edwards, W. F. Am. Chem. J., 16, 625-34 (p. 629): 2222, 226I, 3222, 326I.

693. Étard, M. Ann. chim. phys. (7), 2, 503-74 (pp. 558, 563): 4I, 4I3, 423, 43, 433, 45, 453 .

694. Fessenden, R. A. Phil. Mag. (5), 38, 567-8: 2245.

695. Guye, P. Arch. sci. phys. nat. Genève (3), 31, 38-48, 164-76: 2213 .

696. Holleman, A. et A. Antusch. Rec. trav. chim., 13, 273-306: 423.

697. Jahn, H. und G. Möller. Z. physik. Chem., 13, 385-97 (p. 395): 33, 3322, 3361 .

698. Jones, H. C. Z. physik. Chem., 13, 419-36 (p. 433): 422, 426.

699. Jones, H. C. Z. physik. Chem., 14, 346-60: 224, 525 .

700. Kawalki, W. Wied. Ann. 52, 300-27: 2243, 3243.

701. Kerler, A. Diss. Errlangen: 224r, 2242, 425.

702. Kowalski, J. de. C. r. acad. sci. Paris, 119, 512-3: 3223.

703. Linebarger, C. E. Chem. News, 70, 52: 3227, 3233 .

704. Louguinine, W. C. r. acad. sci. Paris, 119, 60I-4: 21, 2137, 2237, 23, 2337.

705. Mariezcurrena, A. N. de. Treatise, Madrid, Manual del fabricante de alcoholes: 15.

706. Nernst, W. Z. physik. Chem., 14, 622-63 (p. 659); J. B., 206: 2245. 
707. Nernst, W. und R. Abegg. Z. physik. Chem., 15, 681-93: 3234, 63123.

708. Pictet, R. C. r. acad. sci. Paris, $119,678-82: 3234$.

709. Ramsay, W. Proc. Roy. Soc. London, 56, I7I-82; Z. physik. Chem., 15, I06-16: 2213.

710. Schall, C. Z. physik. Chem., 14, 70I-8; 19, 699 (I896): 224I, 324I, 63IIII, 63II 32 .

711. Schlamp, A. Diss. Giessen; Z. physik. Chem., 14, 272-85 (p. 276): 23, 2313.

712. Slotte, K. F. Öfvers. af Finska Vet. Soc. Förhdl., 37, r I-8; Wied. Ann. Beib., 19, 547 (1895): $22,26$.

713. Sorel, E. Treatise, Paris: 6,87 .

714. Sorel, E. C. r. acad. sci. Paris, $118,1213-5: 3228,87$.

715. Strindberg, N. Z. physik. Chem., 14, I6 I-2: $324 I$.

716. Sutherland, W. Phil. Mag. (5), 38, 188-97: 3 .

717. Tammann, G. und Hirschberg. Z. physik. Chem., 13, 543-9: 2222, 22221, 63II32.

718. Thorpe, T. E. and J. W. Rodger. Phil. Trans., 185, A, 397-710 (p. 532); Z. physik. Chem., 14, 36I-73; J. Chem. Soc. London, 71, 360-75 (1897); C. B. (1897), I, 674, III8; Phil. Trans., 189, A, 71-107 (1897) $13,2213,2226$.

719. Thwing, C. B. Z. physik. Chem., 14, 288-300 (pp. 293, 295, 298): 13, 2245, 3245.

720. Tornoë, H. Bull. soc. chim. (3), 11, I r6-20: 723 .

721. Verschaffelt, J. Z. physik. Chem., 15, 437-56: 23, 2327, 423.

722. Wildermann, M. Z. physik. Chem., 14, 23I-46 (p. 232); J. B., 2I4: 224I, 63II32, $632 I I I, 6322$.

723. Wildermann, M. Z. physik. Chem., 14, 247-71: $224 I$.

724. Wirkner, C. G. v. Diss. Basel; Wied. Ann. Beib., 19, 3 I9 (I895): 2227.

725. Woelfer, J. Diss., Halle; Z. physik. Chem., 15, 510: 2233, 423, 425.

726. Young, S. Phil. Mag. (5), 37, I-8: 2223.

\section{5}

727. Andrews, L. und C. Ende. Z. physik. Chem., 17, 136-44: 23, 43, 433.

728. Battelli, A. Ann. chim. phys. (7), 5, 256-75: 2213, 2221, 2223, 2227.

729. Baumhauer, E. H. von. Tables, Haag: 73

730. Beckmann, E., G. Fuchs und V. Gernhardt. Z. physik Chem., 18, 473-513 (pp. 500, 510): 2233, 2237, $23,2333,2337,425$.

731. Bodländer, G. Z. physik. Chem., 16, 729-30: 423.

732. Cantamezza, F. Treatise, Milan: 15.

733. Cari-Mantrand, M. C. r. acad. sci. Paris, 120, 1063-4; Chem. Rep., 19, I79: 424, 64

734. Cattane0, C. Rend. R. Acc. Lincei (5), 4, II, 63-70, 73-7; Wied. Ann. Beib., 20, 209-10 (I896): 2241.

*735. Crismer, L. Bull. roy. acad. Belg. (3), 30, 97-124; Bull. assoc. belg. chim, 9, I45-72, 359-75; 10, 312-6 (1896): $422,61123,62123$.

736. Estreicher, Thad. Phil. Mag. (5), 40, 454-63 (p. 462): 2213.

737. Fonzes-Diacon, — J. pharm. chim. (6), 1, 59; J. Chem. Soc. London, Abst., 68, II, $223: 423$.

*738. Glasenapp, M. Z. angew. Chem., 8, 657-63; J. Chem. Soc. London, Abst., 70, II, 277-8 (I896): 625

739. Hopkinson, J. Phil. Mag. (5), 39, 134: 2245.

740. van Laar, J. J. Z. physik. Chem., 18, 267-74: 2213, 3242.

741. Lehfeldt, R. A. Phil. Mag. (5), 40, 398; 46, 42 (I898): 2222, 2233, 226r, 3, 63IIII, 63II $32,63 I I 33$.

742. Pictet, R. C. r. acad. sci. Paris, 120, 43-6: 2223, 6rI25.

743. Pictet, R. und M. Altschul. Z. physik. Chem., 16, 18-23: 3234 .

744. Pictet, R. und M. Altschul. Z. physik. Chem., 16, 26-28: 6, 6II25.

745. Plato, F. Kais. Norm. Eich. Komm., Berlin: $721,75$.

746. Rocques, $\mathrm{X}$. Treatise, Paris: 62 .

747. Russisches Finanzministerium. Petersburg: 721 .

748. Schönrock, O. Z. physik. Chem., 16, 29-44 (p. 38): 42I, 2253, 23, 2353.

749. Traube, J. Z. anorg. Chem., 8, 338-47: 2211, 2213.

*750. Wislicenus, H. und L. Kaufmann. Ber. chem. Ges., 28, 1323-7; Z. angew. Chem., Abst. 8, 576: 631125,86 .

751. Zecchini, F. Gazz. chim. ital., 25, II, 269-84: $226 r$.

1896

752. Barbet, E. et Jandrier. Ann. chim. anal. appl., 1, 325; C. B. (1897) II, 226; Chem. Rep., 20, 275: 6121. 753. Barbet, E. et Jandrier. Ann. chim. anal. appl., 1, 367 ; C. B. (I897) II, 233: $616,626$.

754. Barendrecht, H. P. Diss. Amsterdam; Z. physik. Chem., 20, 234-4I: 2234, 42, 63123.

755. Battelli, A. Ann. chim. phys. (7), 9, 409-32: 2222, 2222I, 2223.

756. Biernacki, V. Wied. Ann., 59, 664-7: 86 .

757. Carrara, G. Gazz. chim. ital., 26, I, I19-96: $21,214,2142$.

758. Cattane0, C. Atti R. accad. Lincei (5), 5, 207-14; Fortschr. Phys. (I896) II, 545: 2243. 
759. Cinelli, M. Nuov. Cimento. (4), 3, 141-51; Wied. Ann. Beib., 20, 671-2: 2222, 3222.

760. Cole, A. D. Wied. Ann., 57, 290-310: 2248, 2249, 3248, 3249.

761. Drude, P. Wied. Ann., 58, I-20 (p. 14): 2247.

762. Fonzes-Diacon, M. Bull. soc. chim. (3), 15, 762-3: 423, 521

763. Francois, M. J. pharm. chim. (6), 5, 52I-5; C. B. (1897) II, I44; Chem. News., 76, 78 (I897): 622.

764. Freyer, F. Z. angew. Chem., 10, 654-8 (p. 657); C. B. (1897) I, 266: 723.

765. Gros, H. Treatise, Paris: 71 .

766. Heydweiller, A. Wied. Ann., 59, 193-212 (p. 207): 2226

767. Holborn, L. und W. Wien. Wied. Ann., 59, 21 $3-28$ (p. 227): 2234

768. Konowaloff, D. P. Russ. Pharm. Z., 35, 328-9; C. B. II, 338; J. Chem. Soc. London. Abst., 72, II, 374 (I897): 631125,768 .

769. Lampa, A. Sitzb. Akad. Wiss. Wien., 105, IIa, $587-600$ (p. 599): 2249.

770. Lépinay, J. M. de. J. de phys. (3), 5, 266-72: 3225,721,83.

771. Lescoeur, H. Ann. chim. phys. (7), 9, 537 (p. 540): $771,631142$.

772. Linebarger, C. E. Am. J. Sci. (4), 2, 331-40; Z. physik. Chem. Ref., 22, 137 (1897); Wied. Ann. Beib., $21,946(1897): 3226$.

773. Löwenherz, R. Z. physik. Chem., 20, 283: 3242.

774. Marshall, D. and W. Ramsay. Phil. Mag. (5), 41, 38-52; (5), 43, 27-32 (1897); Proc. Phys. Soc. London, $14 ; 57: 2237$.

775. Merck, E. Chem. Ztg., 20, 228: 6r4.

776. Nicloux, M. C. r. acad. sci. Paris, 123, 202; Chem. Rep., 20, 313: 624.

777. Parmentier, P. C. r. acad. sci. Paris, 122, 135-6: 423.

*778. Paul, J. Diss. Würzburg; Z. anal. Chem., 35, 647-59; J. Chem. Soc. London. Abst., 72, 235-6 (I897) $6121,61214,622,6321,6322$.

779. Petersen, E. M'́m. acad. roy. sci. Dunemark, 7, 77-roo; Danske. Vidensk. Selskab., 8, 77: 21, 2113 , 2127.

780. Pettinelli, P. e B. Marolli. Riv. scient. ind., 28, 24-66; Wied. Ann. Beib., 21, I82 (1897); Fortschr. Phys., 53, II, $2 \mathrm{I}_{4}$ (I897): 2222, 3222, 32221 .

781. Ratz, F. Z. physik. Chem., 19, 94-II2 (pp. 99, 108): 2245.

782. Riccardi, L. Tables, Milan: 73 .

783. Riegler, E. Z. anal. Chem., 35, 27-31: 62122 .

784. Salvadori, R. Gazz. chim. ital., 26, I, 237-54: 2I, 2I4I, 4I, 4I5, 410 .

785. Stutzer, A., und R. Maul. Z. anal. Chem., 35, I59-62; Analyst, 21, 213-4: 6I $5,625$.

786. Tiemann, F., und P. Kriiger. Ber. chem. Ges., 29, 90I-2: 6.

787. Traube, J. Lieb. Ann., 290, 43-I22 (p. 52): $2213,2221$.

788. Traube, J. Ber. chem. Ges., 29, 2732-42 (p. 2734): 2222, 2261.

789. Urbain, G. Bull. soc. chim. (3), 15, 455-6; J. Chem. Soc. Abst., 72, I, 245 (1897): 61214.

790. Wiley, H. W. J. Am. Chem. Soc., 18, 1063-7: 723

791. Zelinsky, N., und S. Krapiwin. Z. physik. Chem., 21, 35 (p. 37): 2I, 2I4, 4I, 413.

\section{7}

792. Abegg, R. Wied. Ann., 66, 54-60 (p. 57): 2245 .

793. Barbet, E. Bull. ass. chim. sucr. dist., 14, 943; C. B., II, II63: 622.

794. Bathrick, H. A. J. physic. Chem., 1, I57-69; C. B., I, I53: 423.

795. Bohr, C. Wied. Ann., 62, 644-5I: 22223, 421 .

796. Carrara, G. Gazz. chim. ital., 27, I, 422-40: $21,2 I I 3,2 I 4 I, 2142,6 I I 2$.

797. Cattane0, C. Atti R. accad. Lincei $(5), 6,89-94$; Fortschr. Phys., II, 583: $22221,423$.

798. Cattaneo, C. Atti R. accad. Lincei (5), 6, 279-86; Fortschr. Phys., II, 605: 2243.

*799. Chappuis, P. Wied. Ann., 63, 202-8: 81,82 .

800. Cotte, J. Diss. Montpellier: 624 .

801. Cotte, J. Rép. pharm. (3), 9, 438; Chem. Rep., 21, 254; C. B. (1898), I, 226: 624.

802. Dewar, J., and J. A. Fleming. Proc. Roy. Soc. London, 61, 358-67; C. B., II, 563-4: 2245.

803. Drude, P. Z. physik. Chem., 23, 267-325 (pp. 299, 309); C. B., II, 245: 2245, 2246.

804. Gilbault, H. Z. physik. Chem., 24, 385-440 (pp. 40I, 4I9, 425); C. B. (I898), I, 83: 32222.

805. Guldberg, C. M. Festschrift Univ. Christiania; Z. physik. Chem., 32, II6-26 (I900): 2212, $2213,2223$.

806. Kuriloff, B. Ber. chem. Ges., 30, 741-3; C. B., I, 949: 624, 626.

807. Lemoine, G. C. r. acad sci. Paris, 125, 603-5 (p. 604); C. B., I, II 3 I: 423.

808. Liverseege, J. F. Analyst, 22, 153-7; C. B., II, 44I: 52.

809. Moretto, P. Nuov. Cimento (4), 6, I98-204: 3I, 3I22.

810. Nernst, W. Wied. Ann., 60, 600-24 (pp. 610-II): 2222, 224I, 2245, 63II32.

811. Nicloux, M. Bull. soc. chim. (3), 17, 839-40; C. B., II, 916: 613, 623. 
812. Nicloux, M. et L. Baudauer. Bull. soc. chim. (3), 17, 424-7: 3228, 7,87 .

813. Philip, J. C. Z. physik. Chem., 24, 18-38 (pp. 19, 3I, 35); C. B., II, 825: 2245, 3245

814. Rocques, X. Ann. chim. anal. appl., 2, I4I; Chem. Rep., 21, I3I: 615, 625.

815. Rohland, P. Z. anorg. Chem., 15, 412-8 (pp. 4I2-3); C. B. (I898), I, 313: 423.

816. Rüping, H. Diss., Erlangen: $2241,324 I$.

817. Scheel, K. Z. Instrkunde., 17, 33 I-5; 18, 32 (1898): 82.

818. Sohet. Bull. inst. phys. Liege, I-56; MIém. soc. roy. sci. Liege (2), 20, I: 2222, 2225, 3225.

819. Spring, W. Rec. trav. chim., 16, I-25 (p. I7); C. B., I, III4: 13, $2213,2264$.

820. Squibb, E. R. J. Am. Chem. Soc., 19, I1 I-4; C. B., I, 955: 84.

821. Szarvasy, E. Ber. chem. Ges., 30, 808-9; C. B., I, Iоr2: 5I, 5114.

822. Tanatar, S. and L. Pissarjewsky. J. Russ. Phys. Chem. Soc., 185: 223, 323, 42.

823. Taylor, A. E. J. Physic. Chem., 1, 719-33; C. B. (I898), I, I71: 42.

*824. Thiesen, M., K. Scheel und H. Diesselhorst. Wied. Ann., 60, 340-49; Wiss. Abh. k. Phys. 'Tech. Reichsanstalt, $3,1-70$ ( 1900$): 81,82$.

825. Thorpe, T. E. J. Chem. Soc. London, 71, 920-5 (p. 923); C. B., II, 541, 61 2: 43.

826. Traube, J. Ber. chem. Ges., 30, 265-77 (p. 274): 2213.

827. Volkmann, P. Schr. phys. ökon. Ges. Königsberg, 38, 43; Fortschr. Phys., 54, II, 310: 2223.

828. Walker, J. and F. J. Hambly. J. Chem. Soc. London, 7I, 6I-72; C. B., I, 353, 578: $224 I, 63 I I I t$.

829. Weber, K. Diss., Göttingen: $5,52,521$.

830. Yvon, P. C. r. acad. sci. Paris, 125, II $81-2$; C. B. (1898), I, 319; Chem. Ztg., 22, 23 (1898); Analyst., 23, 78 (1898); Z. anal. Chem., 38, 448 (I899): 631144.

831. Zaitschek, A. Z. physik. Chem., 24, I'-I2; C. B., II, 83I: 422, 5214.

832. Zecchini, F. Gazz. chim. ital., 27, I, 359-83 (p. 366); C. B., I, I193: 2222, 2233, 226I, 3261, 63IIII, 631145.

833. Zecchini, F. Gazz. chim. ital., 27, I, 466-73: 224.

\section{8}

834. Benedict, F. G. and R. S. Norris. J. Am. Chem. Soc., 20, 293-302; Z. angew. Chem., 11, 448; C. B., I, I069: 3222, 5211,624 .

835. Berthelot, M. C. r. acad. sci. Paris, $126,691-4$ (p. 693 ): 525 .

836. Brunner, L. Z. physik. Chem., 26, 146-51: 423.

837. Cohen, E. Z. physik. Chem., 25, I-45 (p. 12): 2222, 2241, 631132.

*838. Curtis, C. B. J. Physic. Chem., 2, 371-3; Rev. Am. Chem. Research, 5, 35 (I899); C. B., II, 512: $611144,61123,62123,624,631111,631125,631132,631145$.

839. Davidson, W. B. und A. Hantzch. Ber. chem. Ges., 31, 16ז2-48 (p. 1626); C. B., II, 405: 2241.

840. Dewar, J. and J. A. Fleming. Proc. Roy. Soc. London, 62, 250-66; C. B., I, 546-7: 2245.

841. Dodge, N. and L. C. Graton. J. Physic. Chem., 2, 498-501; C. B. (I899) I, 404: 423.

842. Drude, P. Wied. Ann., 64, I3I-58 (p. 155): 2247.

843. Dutoit, P. et L. Friderich. Bull. soc. chim. (3), 19, 32I-37: 224I, 2242, 2244.

844. Fuchs, P. Z. angew. Chem., 11, 869-7r: 3233.

845. Girault, E. Treatise, Paris: $7 x$.

846. Hemptinne, A. de. Z. physik. Chem., 25, 284-99 (p. 288): 224, 525.

847. Istrati, C. Bull. Soc. Sciinte din Bucuresci, 7, 163; Chem. Rep., 22, 198; Rev. intern. fa!s., 12, $9^{1-2}$ (1899); C. B. (1899) II, I48: 612, 6121.

848. Kahlbaum, G. W. A. Z. physik. Chem., 26, 576-658, II; C. B. II, 620-r: 2227.

849. Koenigsberger, J. Wied. Ann., 66, 698-734 (p. 715); C. B. (1899) I, 6: 2252.

850. Ladenburg, A. Ber. chem. Ges., 31, 1968-9: 2234.

851. Lam, A. Z. angew. Chem., 11, I25-30; C. B. I, 690: 623,85 I.

852. Lees, C. H. Phil. Trans., 191, 399 (p. 424): 2232, 3232.

853. Lobry de Bruyn, C. A. et A. Steger. Rec. trav. chim., 18, 311-25; C. B. (I899) II, 86I: 3273, 6riz24.

854. Louguinine, W. Ann. chim. phys. (7), 13, 289-377 (pp. 305, 335); C. B. I, 824: 2237.

855. Marker, M. Berlin, Spiritusindustrie (p. ז7r), 7 te Auflage: 71 .

856. Marx, E. Wied. Ann., 66, 411-34, 597-622 (p. 610); C. B. (I899) I, 5: 2247.

857. Moliniê. Rev. phys. chim., 2, 140; Chem. Rep., 22, 53: 631144.

858. Ostermayer, E. Pharm. Ztg., 43, 99; C. B. I, 658; Chem. Rep., 22, 41: 631144.

*859. Rothmund, V. Z. physik. Chem., 26, 433-92: 3223, 422, 61123.

860. Tanatar, S. und B. Klimenko. Z. physik. Chem., 27, I72-4: 2222, 423.

861. Thayer, E. F. J. Physic. Chem., 2, 382-4; Rev. Am. Chem. Research, 4, 90; C. B. II, 467: 2233, 422, 631132,631145 .

862. Thorpe's Dictionary of Applied Chemistry. Vol. I, pp. 34-9, 39-45; G. N. Stoker: (I9I2) Vol. I, pp. 58-64, 64-9; J. Holmes: $I I, 7 I$.

853. Trillat, A. Bull. soc. chim. (3), 19, 984-9; C. B. II, 585 ; C. B. (1899) I, 153:613,623. 
864. Trillat, A. Bull. soc. chim. (3), 19, 989-92; C. B. II, 585 ; C. B. (1899) I, ז53; C. r. acad. sci. Paris, 127, 232-4: 613,623, 64I, 642 .

865. Vaubel, W. J. prak. Chem. N. F., 57, 337-57; 69, 138-44 (1904): 2213.

866. Vitali, D. Boll. chim. farm., 37, 257; Chem. Rep., 22, I59 (1898): 6 IIII44.

867. Wood, F. Chem. News, 78,308 ; C. B. (1899), I, 335 : 14.

\section{9}

868. Abegg, R. und W. Seitz. Z. physik. Chem., 29, 242-8 (-p. 246); C. B. II, 242: 2213, 2245.

869. Arndtsen, A. Treatise, Christiania: 7,73 .

870. Beckmann, E. und H. Brüggemann. Z. Nahr. Genussm. 2, 709-I4; C. B. II, 73I; 625.

871. Berthelot, D. C. r. acad. sci. Paris, 128, 606-9: 2213, 2223.

872. Berthelot, M. C. r. acad. sci. Paris, 128, 862-4; C. B. I, ror8; J. Chem. Soc. London Abst., 76, I, 47 I: 14.

873. Biltz, W. Z. physik. Chem., 29, 249-65, C. B. II, 243: 23, 2334, 426.

874. Brüggemann, H. Separate, Leipzig: 625 .

875. Briihl, J. W. Z. physik. Chem., 30, I-63: 2213.

876. Bücheler, M. et E. Légier. Treatise, Paris: 15 .

877. Cavalier, J. Ann. chim. phys. (7), 18, 449-507; C. B. (1900), I, 102: 5213.

878. Cohen, E. Z. physik. Chem., 28, 145-53: 3273 .

879. Coolidge, W. D. Wied. Ann., 69, 124-66 (pp. I49, I51): 2245

880. Dejonghé, G. Treatise, Lille: $I I, I 5$.

881. Dennhardt, R. Wied. Ann., 67, 325-44: 2226, 2241.

882. Euler, H. Z. physik. Chem., 28, 6r9-27: 2213, 2244, 2245.

883. Girard, C. et L. Cuniasse. Treatise, Paris: $I I, 88$.

884. Haywood, J. K. J. Physic. Chem., 3, 317-27 (p. 318); C. B., II, 410: 2233, 422, 424, 631132, 631145.

885. Hempel, W. and J. Seidel. Ber. chem. Ges., 31 2997-300I (p. 3000); C. B., I, $96: 42$.

886. Jandrier, E. Ann. chim. anal. appl., 4, 156; C. B., I, г296: 613.

887. Jones, H. C. Z. physik. Chem., 31, Ir ${ }^{-4}$ I (p. I33); C. B. (I900), I, 32I: 2244, 4I, $415,425$.

888. Kahlenberg, L. and A. T. Lincoln. J. Physic. Chem., 3, I2-35 (p. 26); C. B., I, 810: 2244.

889. Kannonikow, I. I. J. Russ. Phys. Chem. Soc., 31, 573-640; 33, 6r-82 (I90I); C. B., II, 858 ; ibid. (Igor), I, 985; Wied. Ann. Beib., 25, 910 (1901): 13, 2213, 2222.

890. Kuenen, J. P. and W. G. Robson. Phil. Mag. (5), 48, 180-203; C. B., II, 409; Z. physik. Chem., 28, $342-65$; C. B., I, 867: 21, 2133, 2233, 422, 63II44, 63II45.

891. van Laar, J. J. Z. physik. Chem., 31, I-I6 (p. 5); C. B. (I900), I, 243: 2213.

892. Ladenburg, A. und C. Krügel. Ber, chem. Ges., 32, I818-22 (p. 1821); C. B., II, 24I: 2234.

893. Lehfeldt, R. A. Phil. Mag. (5), 48, 215-7; Z. physik. Chem., 29, 498-500: 2227, 42.

894. Magie, W. F. Phys. Rev., 9, 65-85 (pp. 80, 84); Physik. Z., 1, 233 (I900): 223 I.

895. Mulliken, S. P. and H. Scudder. Am. Chem. J., 21, 266-7r; Rev. Am. Chem. Research, 5, 68-9: 6r3. 896. Oettgen. Diss. Rostock: 2225.

897. Pettit, J. H. J. Physic. Chem., 3, 349-63; C. B., II, 694: $2233,3233,424$.

898. Raikow, P. N. Chem. Ztg., 23, 145-7; C. B., I, 824: 2235.

899. Thayer, E. F. J. Physic. Chem., 3, 36-40; Rev. Am. Chem. Research, 5, 47-8; C. B., I, 8Ir: 2233, $3233,42$.

*900. Tischtschenko, W. J. Russ. Phys. Chem. Soc., 31, 694-770, 784-872; C. B. (1900), I, 10-12, 585-6: 5213. 901. Trillat, A. Ann. Chim. anal. appl., 4, 42-44; C. B., I, 641-2: 613.

902. Trillat, A. C. r. acad. sci. Paris, 128, 438-40; C. B., I, 759: 613.

903. United States Dispensatory, 18th Edition, pp. I23, I27, I836, Alcohol; p. I880, Alcoholometry: II, 7 .

904. Watt's Dictionary of Chemistry, London, Vol. I, p. 94-9, Alcohol: II.

905. Wolff, J. Ann. chim. anal. appl., 4, I83-4; C. B., II, 229; Z. anal. Chem., 40, 668 (Igor): 6r3.

\section{0}

906. Berthelot, D. C. r. acad. sci. Paris, 130, 565-8: 2213.

907. Bohr, C. Ann. Physik., 1, 244-56; C. B.,I, 578: 421 .

908. Bull, H. Chem. Ztg., 24, 814-5, 845-7; C. B., II, 993; J. Chem. Soc. London. Abst., 80, II, I37-8: 63.

909. Dufet, H. Recueil de données numériques publie par la société francaise de physique optique, p. 93-6 (alcool éthylique); p. 96-8 (alcool methylique) Optical constants: $21,2122,216 \mathrm{I}, 2165,2222$, 2261,2265 .

910. Dujardin, J. Paris: I2.

911. Dutoit, P. et L. Friderich. C. r. acad. sci. Paris, $130,327: 2$.

912. Elbs, K. und O. Brunner. Z. Elektrochem, 6, 604-9; C. B., II, 240: 525.

913. Guglielmo, G. Att. Rend. Linc. (5), 9a, 9; (5), 9a, 33, 70; (5), 9b, 26r: 72I, 83, 84 . 
914. Hantzsch, A. Z. anorg. Chem., 25, 332-40: 224I, 2244, 324.

915. Heinrich, Gg. Sitzb. Akad. Wiss. München, 33-6; C. B., II, I 56: 3251 .

916. Hesehus, N. J. Russ. Phys. Chem. Soc., 32, 97-102; J. de phys. (4), 1, 49-50 (I90I); C. B., II, 410: $3225,3245$.

917. Jones, H. C., and A. W. Smith. Am. Chem. J., 23, 397-403; C. B., II, 3: 224 .

918. Klein, H. Ann. chim. anal. appl., 6, 75 et 85; Z. Unters. Nahr. Genussm., 1, 405, 637; Z. anal. Chem., 39, 471: 3222 .

919. Lees, C. H. Phil. Mag. (5), 49, 286-93 (p. 289): 3232.

920. Loomis, E. H. Z. physik. Chem., 32, 578-606 (p. 591); C. B., I, 897: 2222, 3234 .

921. Meyer, Kristine. Z. physik. Chem., 32, I-38 (pp. 15, 16): 2223.

*922. Mulliken, S. P., and H. Scudder. Am. Chem. J., 24, 444-52; C. B., II, I 294: 6r3.

923. Norm. Eich-Komm. Berlin. Alkoholermittelungsordnung. Branntweinsteuer=Ausführungsbestimmungen. Amtliche Ausgabe: 624,7 .

924. Oechsner de Coninck. C. r. acad. sci, Paris, 131, 58-60; C. B., II, $365: 423$.

925. Plato, F., J. Domke und.H. Harting. Kais. Norm. Eich-Komm. Wiss. Abh., 2: $2,8,83$.

926. Springuel, A. Treatise, Huy: $624,7,73$.

927. Sulc, O. Z. anorg. Chem., 25, 399-404 (p. 402); C. B. (I901), I, 89: 423.

928. Tumlirz, O. Sitzb. Akad. Wiss. Wien., 109, IIa, 837-48; Wied. Ann. Beib., 25, 80I (I90I): 22222.

929. Vrevskij, M. J. Russ. Phys. Chem. Soc., 32, 593; Fortschr. Phys., I, 91: 3227, 423.

\section{1}

930. Bädeker, K. Z. physik. Chem., 36, 305-35 (p. 327): 2245.

931. Busnikoff, W. I. J. Russ. Phys. Chem. Soc., 33, r28-43; J. Chem. Soc. London, Abst., 80, I, 306 ; C. B. I, II9I: $2222,3222,422$.

932. Carrara, G., und A. Coppadoro. Mem. R. Acc. Linc., 3I7-37; Z. physik. Chem., 44, 379 (I903): 2I, $2134,2234,63123$.

*933. Cook, A. N., and A. L. Haines. Proc. Iowa Acad. Sci., 9, 86-90: 21, 2122, 2222, $23,631144$.

934. Freyer, F. Z. landw. Versuchsw. i. Oesterr., 4, 955; Chem. Rep., 25, 308: 624.

935. Guerbet, M. C. r. acad. sci. Paris, 133, 300-2; C. B. (I902), II, 339: 14, 5213

936. Guinchant, M. C. r. acad. sci. Paris, 132, 469-72; C. B., I, 77I: 2213, 22222.

937. Hardt, W. Diss. Erlangen: 2241, 2244.

938. Ipatiew, W. Ber. chem. Ges., 34, 3579-89; C. B., II, I $247: 522$.

939. Jones, H. C. Am. Chem. J., 25, 232-49; pp. 236, $238: 21,2144,2244$.

940. Just, G. Z. physik. Chem., 37, 342-67; C. B., II, 81: 421.

941. Koppel, J. Z. anorg. Chem., 28, 46I-73: 2241, 631132, 423.

942. Krümmel. Wiss. Meeresuntersuchuigen (N. F.), 5, Heft 2: 721 .

943. Lefebre, P. C. r. acad. sci. Paris, 132, I221-3: 5213, 631144 .

944. Lulofs, P. K. Diss. Amsterdam: $41,413,423,5213$

945. Malméjac. J. pharm. chim. (6), 13, 169-7; J. Chem. Soc. London, Abst. 80, I, 248; C. B. I; 607: 521. 946. Mather, W. T. Am. Chem. J., 26, 473: 224I, 324I, 2243, 3243.

947. Mühlenbein, J. Diss. Cöthen; Z. physik. Chem. Ref., 47, 380 (I904): 2226.

*948. Noyes, W. A., and R. R. Warfel. J. Am. Chem. Soc., 23, 463-8; Rev. Am. Chem. Research, 7, r54; C. B., II, 621: 2222, 3222, 2233, 3233, 42 .

949. Patterson, T. S. J. Chem. Soc. London, 79, 169-216 (p. I74): 21, 2153, 2253, 23, 2353.

950. Rimini, E. Atti. R. Accad. Lincei (5), 10, I, 355-62; C. B., II, 99; Gazz. chim. ital., 31, II, 84; Chem. Rep., 25, 363: 6121.

951. Roozeboom, H. W. B. Archiv. Néerl. (2), 6, 430-4I; C. B. (I902), I, 292: 3239.

*952. Rudolphi, M. Physik. Z., 2, 447-8: 84 .

953. Tischtschenko, W. J. Russ. Phys. Chem. Soc., 33, I73-5: 523.

954. Tolkatschew, S. J. Russ. Phys. Chem. Soc., 33, 469-74; C. B., II, I200: 5213.

955. Trillat, A. C. r. acad. sci. Paris, 132, I227-9; C. B., I, 26, I78; Monograph, Paris: 522.

956. Wenzel, E. Diss. Bonn: 22223.

1902

957. Cardosa-Pereira, A. Bull. soc. chim. (3), 27, 555-6: 61.

958. Carrara, G. e L. d'Agostini. Att. Venet. Inst., 42, 793-802: 2I, 214I, 2142.

959. Carrara, G. e M. G. Levi. Gazz. chim. ital., 32, II, 36-53 (p. 42): C. B., I, 923: 2222, $2233,2241,3241$.

*960. Crismer, L. Bull. assoc. chim. Belg., 16, 83-94; C. B., II, 3; 2, 2224, 61123, 62123.

*961. Domke, J. Wiss. Abh. k. Norm. Eich.-Komm., 3, I-100 (p. 57). Literaturnachweis: 225, 88.

962. Eisenstein, A. Diss. Berlin: 2243 .

963. Eversheim, P. Ann. Physik (4), 8, 539: 2223, 224I, 2245

964. Fischern, Th. Tables, Leipzig: 73 . 
965. Fritzsche, P. J. prak. Chem. N. F., 165, 597-600; C. B., II, 339; J. Chem. Soc. London, Abst., 82, I, 657: 14 .

966. Grunmach, L. Wiss. Abh. k. Norm. Eich-Komm., 3, 10I-98 (p. 155-9I): 2222, 2225.

967. Hantzsch, A. and E. Voegelen. Ber. chem. Ges., 35, 1001-9 (p. 1002); C. B., I, 867: $2241,631132$.

968. Hausrath, H. Ann. Physik., 9, 522-54 (p. 543); C. B., II, 1272: 426.

969. Hofer, H. und M. Moest. Lieb. Ann., 323, 284-323; Z. Elektrochem. 9, 477 (1903); C. B., II, I094: I4, 525 .

970. Jones, H. C. and C. F. Lindsay. Am. Chem. J., 28, 330-70 (p. 339); Z. physik. Chem., 56, I 29-78 (I906): $21,2141,224 I, 23,2341,631111,631132,631145$.

971. Larbalêtrier, A. Treatise, Paris: $I I$.

972. Leduc, A. C. r. acad. sci. Paris, $134,645-8$; C. B., I, 964: $326 x$.

973. Meunier, L. C. r. acad. sci. Paris, 134, 472-3: 5213, 631124 .

*974. Middelveld Viersen, W. Diss. Utrecht: 5211,632112 .

975. Norm. Eich.-Komm. Mitth., 2, I43 (Feb.): 73.

976. Patten, H. E. J. Physic. Chem., 6, 554-70 (p. 568): 2, 224.

977. Raikow, P. N. Chem. Ztg., 26, 436-9; C. B., I, I398: 2235, 3235

978. Rayleigh, Lord. Phil. Mag. (6), 4, 521-37; C. B., II, I400: 3228.

979. Roth, W. A. Z. physik. Chem., 42, 214-24: 3241 .

980. Schlötter, M. Diss. Nürnberg: 525 .

981. Skirrow, F. W. Z. physik. Chem., 41, I39-60 (p. I55); C. B., II, 422 : 42 .

982. Slaboszewicz, J. Z. physik. Chem., 42, 343-52; C. B. (1903), I, 279: 5211.

983. Sociêté S. Jay et Cie. D. R. P. I49, 893 June 21; Chem. Ztg., 28, 389 (I904): I4.

984. Stevens, E. H. Ann. Physik., 7, 285-320 (pp. 315, 320): 2271.

985. Wolf, H. Z. physik. Chem., 40, 222-55; Z. Elektrochem., 8, II 7-9: 324I.

*986. Young, S. J. Chem. Soc. London, 81, 707-r7. C. B., I, I3I7; Pharm. J. (4), 17, I66 (I903); C. B. (I903), II, 869: 2222, 63122.

*987. Young, S. and E. C. Fortey. J. Chem. Soc. London, 81, 717-39; C. B., II, 103: 31, $32,33$.

*988. Young, S. and E. C. Fortey. J. Chem. Soc. London, 81, 739-52; C. B., I, I3I7, II, 102: 2, $422,424$.

1903

989. Aubel, E. van Arch. sci. phys. nat. Genève (4), 15, 78-8I; Ann. Physik. Beib., 27, $755: 2264$

990. Bordier. C. r. acad. sci. Paris, 136, 459-6I; J. Chem. Soc. London, Abst., 84, II, 264; C. B., I, 737: 2236, 3236,7 .

991. Brown, J. C. J. Chem. Soc. London, 83, 987-94 (p. 99I); C. B., II, 650: 2237.

992. Coffetti, G. Gazz. chim. ital., 33, I, 53-68: 2I, 2133, 2141, 25, 2533, 2541.

993. Dempwolf, C. Diss., Rostock: $21,2143$.

994. Doby, Gêza. Magy. Chem. F. (Budapest), 9, II5-8, 133-7: 5213.

995. Doby, Géza. Z. anorg. Chem., 35, 93-I05; C. B., I, I403-4: 421, 5213.

996. Dutoit, P. J. chim. phys., 1, 6I 7-56: 2, 224I, 2242.

997. Ehrenfeld, R. J. prak. Chem. (2), 67, 49-93; C. B., I, 758; Chem. Rep., 27, 67: 521, 522.

998. Ehrenfeld, R. J. prak. Chem. (2), 67, 428-9; C. B., I, I296: 522.

999. Euler, H. Arkiv Kemi, Min. Geol. Stockholm, 1, 203-20 (p. 213); Fortschr. Phys. (I904), I, 439: 2213,521 .

1000. Giammarco, A. Nuov. Cimento (5), 5, 377-9I; Fortschr. Phys., II, 526: 2223.

1001. Haas, B. Z. landw. Versuchsw. i. Österr., 6, 808; Chem. Rep., 28, 37 (I904): 723.

1002. Haffner, G. Diss., Erlangen; Ann. Physik. Beib., 28, $95^{2}$ (I904): 2226.

1003. Helmreich, C. Diss., Errlangen; Ann. Physik. Beib., 28, 397 (I904); Fortschr. Phys., 59, II, 57I: 2231,3231 .

1004. Ipatiew, W. J. prak. Chem. N. F., 67, 420-2; C. B., I, I296; Chem. Rep., 27, I22: 522.

1005. Kablukow, I., A. Solomonow, und A. Galine. Z. physik. Chem., 46, 403-7; C. B. (I904), I, 423-4: 3227,3228 .

1006. Komarowsky, A. Chem. Ztg., 27, 807-8; C. B., II, 742: 615.

1007. Kowalski, J. et B. Zdanowski. Krakauer Anzeiger, 793-4; Arch. sci. phys. nat. Genève (4), 18, 105-34 (I904): 2241 .

1008. Kraus, A. Chem. Ztg., 27, 296, 1093: 14 .

1009. Kuenen, J. P. Phil. Mag. (6), 637-53: 422 .

1010. Lemoult, P. C. r. acad. sci. Paris, 137, $5^{15-7}$; C. B., II, I048; J. Chem. Soc. London, Abst., 86, II, I2 (I904): 2239 .

1011. Lobry de Bruyn, C. A. and C. L. Jungius. Versh. Akad. Wets. Amsterdam, 12, I56-8: 31,3141 .

1012. Longinescu, G. G. J. chim. phys., 1, 289-95 (p. 294): 2213.

1013. Monti, V. Z. angew. Chem., 16, 582: 2234, 63123. 
1014. Rudorf, G. Z. physik. Chem., 43, 255-304 (pp. 259-60, 286, 294); C. B., I, 1113: 2213, 2226, 2241 .

1015. Sabatier, P. et J. B. Senderens. C. r. acad. sci. Paris, 136, 738-4I; C. B., I, 955: 521, 522.

1016. Sabatier, P. et J. Senderens. C. r. acad. sci. Paris, 137, 301-3; C. B., II, 708: 522, 63212.

1017. Schiikarew, A. Z. physik. Chem., 44, 548-62 (p. 554); C. B., II, 649: 2223.

1018. Simonson. 5 th Int. Cong. App. Chem. Berlin; Z. angew. Chem., 16, 572: 14.

1019. Solomonov, L. S. Farmacevt. Moskva, 583-5, 657-9, 698-700: $3227,3228$.

1020. Trillat, A. Bull. soc. chim. (3), 29, 35-47; C. B., I, 438: 522.

1021. Varenne, E. et L. Godefroy. C. r. acad. sci. Paris, 137, 993-6; C. B. (1904), I, 256: $321,42$.

1022. Vittenet, H. Bull. soc. chim. (3), 29, 89-92; C. B., I, 490: 3222.

1023. Vorländer, D. Ber. chem. Ges., 36, 268-8I (p. 272): 2241, 631132.

1024. Wagner, B. Diss. Jena: 62122 .

1025. Wagner, J. und J. Mühlenbein. Z. physik. Chem., 46, 867-77: 2226, 3226.

1026. Walden, P. Z. physik. Chem., 46, 103-88 (pp. III, 132); C. B. (1904), I, 573: 2241, 2244.

1027. Young, S. J. Chem. Soc. London, 83, 68-77: $3228,3233$.

1028. Young, S. J. Chem. Soc. London, 83, 77-83: 422.

1029. Young, S. London: $63121,63122,87$.

1030. Bone, W. A. and W. E. Stockings. J. Chem. Soc. London, 85, 693-727 (p. 722); C. B., II, 16, 301: 52. 1031. Bouveault, L. C. r. acad. sci. Paris, 138, 984-5: 6, 613 614,615 .

1032. Brïhl, J. W. Ber. chem. Ges., 37, 2066-8; Chem. Rep., 28, I86: 521.

*1033. Crismer, L. Bull. soc. chim. belg., 18, 18-54; C. B., I, 1479-81: 2I, 2122, 2222, 22221, 23, 2322, 6II23, $62123,631132$.

1034. Duchemin, R. et J. Dourlen. C. r. acad. sci. Paris, 139, 679-8r: 21, 2133, 2233, 521 .

1035. Dunstan, A. E. J. Chem. Soc. London, 85, 8r7-27; Z. physik. Chem., 49, 593; J. Chem. Soc. London, 87, II-7 (1905), id., II; Z. physik. Chem., 51, 732-8 (1905); Ann. Physik. Beib., 29, 374 (1905): 2226, 3226.

1036. Emmerling, O. Ber. chem. Ges., 37, 3535-8; C. B., II, 1577; Ber. chem. Ges. 38, 953-6 (1905); C. B. (I905) I, 947: 16.

1037. Evans, T. and W. C. Fetsch. J. Am. Chem. Soc., 26, II 58-6r; C. B., II, I383: 63II24.

1038. Feitler, L. Monograph, Wien: $x 4$.

1039. Godlewski, T. Krakauer Anzeiger, 239-76; Fortschr. Phys., I, 523: 224T, 61.

1040. Goldiner. Z. Spiritusind., 27, 58: 73.

1041. Hall, E. F. Boltzmann Festschrift, 899; Contrib. Jefferson Phys. Lab. Harvard, 2 (1904): 2213, 2223.

1042. Jones, H. C. and H. P. Bassett. Am. Chem. J., 32, 409-45 (p. 432): 324I, 3243.

1043. Jones, H. C. and C. G. Carroll. Am. Chem. J., 32, 52I-83: 2I, 2126, 214I, 2226, 224I, 3I, 3I26, 3I4I, $3226,324 I$.

1044. Jones, H. C. and F. H. Getman. Am. Chem. J., 32, 338-42; C. B., II, I445: 224, 423.

1045. Kitt, M. Chem. Rev. Fett. Harz. Ind., 11, 173: 61215, 622, 632113, 63213.

1046. Lobry de Bruyn, C. A. und A. Steger. Z. physik. Chem., 49, 336-40: 3273, 63IIIIt.

1047. Matthes, H. Z. anal. Chem., 43, 73-84: (p. 8I); C. B., I, Ir69: 62122.

1048. Mills, J. E. J. Physic. Chem., 8, 383-415 (pp. 392, 414); 8, 593-636 (p. 612): 2213, 2237.

1049. Morley, E. W. J. Am. Chem. Soc., 26, Ir $71-3: 85$.

*1050. Morley, E. W. J. Am. Chem. Soc., 26, 1185-93: 73.

1051. Raikow, P. N. und P. Schtarbanow. Chem. Ztg., 28, 886-8; C. B., II, I260: 3235, 62125 .

1052. Schreinemakers, F. A. H. Z. physik. Chem., 47,445-70; 48, 257-88; C. B., I, 1050, II, 170: 424, 631132.

1053. Thorpe. T. E., and J. Holmes. J. Chem. Soc. London, 85, I-6; C. B., I, 756: 623.

1054. Tijmstra Bz, S. Z. physik. Chem., 49, 345-67; C. B., II, III4: 224I, 324I, 63IIII.

1055. Traube, J. Z. anorg. Chem., 38, 399-409 (p. 408): 2223.

1056. Varenne, E., et L. Godefroy. C. r. acad. sci. Paris, 138, 79-82: 72.

1057. Varenne, E., et L. Godefroy. C. r. acad. sci. Paris, 138, 990-2: 4I.

1058. Vèzes, M., et M. Moulin. Bull. soc. chim. (3), 31, ro43-9; C. B., (1905), II, I571-2: 422, 6 II $^{2} 3$.

1059. Ždanovič, M. L. J. Russ. Phys. Chem. Soc., 36, 765-6: 522.

\section{5}

1060. Barlow, P. S. Phil. Mag. (6), 10, I-I2; C. B., II, 373; Phil. Mag. (6), 11, 595-604 (1906): 3224-

1061. Beckmann, E. Z. Nahr. Genussm., 10, 143-52; C. B., II, 790; J. Chem. Soc. London, Abst., 88, II, 768: 625 .

*1062. Bredig, G., und W. Fraenkel. Z. Elektrochem., 11, 525-8; C. B., II, 805: 3273, 6ri24.

1063. Carrara, G., e L. d' Agostini. Gazz. chim. ital., 35, I, 132-44; C. B., I, 1455: 21 , 214.

1064. Clarke, B. M. Physik. Z., 6, I54-9; C. B., I, 916: 32224, 3239.

1065. Cohen, E., und Th. Strengers. Z. physik. Chem., 52, r29-70 (p. 154): 2231, 631132 . 
1066. Crismer, L. Bull. soc. chim. belg., 19, 233-4: 61123, 62123.

1067. Duchemin, R., et J. Dourlen. C. r. acad. sci. Paris, 140, I466-8; C. B., II, Ir $3: 619,620$

1068. Ehrlich, F. Z. Ver. Zuckerind., 55, 539-67; C. B., II, I 56 : I6.

1069. Elektrochemische Werke G. m. b. H., Bitterfeld, D. R. P. r75780 (Sept. 30); Chem. Rep., 30, 389 : $63 I I I 3$.

1070. Frazee, J. C. Proc. Iowa Acad. Sci., 12, I79-92: I4.

1071. Gaunt, R. Z. anal. Chem., 44, 106-8; C. B., I, 1051: 3234, 62125, 72.

1072. Goebel, J. B. Z. physik. Chem., 53, 213-24 (p. 222): 2213.

1073. Guttmann, L. F. J. Chem. Soc. London, 87, 1037-42; C. B., II, 669; J. Am. Chem. Soc., 29, $345-8$ (1907); C. A. I, I843 (1907); C. B. (1907), I, I664: 2234.

1074. Herz, W., und M. Knoch. Z. anorg. Chem., 45, 262-9 (p. 265); C. B., II, 93: 423.

1075. Jones, H. C., and E. C. Bingham. Am. Chem. J., 34, 48I-554: 2I, $2126,214 I, 2226,224 I$.

1076. Kremann, R. Monatsh., 26, 279-313; C. B., I, 979-80: $3273,422$.

1077. Leach, A. E., and H. C. Lythgoe. J. Am. Chem. Soc., 27, 964 ; Chem. Rep., 29, 262: 613, 614, 623, $624,72$.

1078. Mathieu, L. Bull. ass. chim. sucr, dist., 22, I283-93: $5211,526$.

1079. Pringsheim, H. H. Ber. chem. Ges., $38,486-7 ;$ C. B., I, 687 : 16

1080. Reiferscheidt. Z. angew. Chem., 18, 44-8: 14 .

1081. Sadtler, S. P. Am. J. Pharm., 77, 106; Rev. Am. Chem. Research, 11, 279: 613.

*1082. Scudder, H. J. Am. Chem. Soc., 27, 892: 613.

1083. Szilard, B. Gyógysz. Köz1. Budapest, 21, 669-70, 684-7, 700-x, 7 r $_{5}-7$; Z. Elektrochem., 12, 393-5 (1906); C. B. (I906), II, 594; Chem. Rep., 30, 185 (1906): 2222, 525, 6321.

1084. Thomsen, J. Z. physik. Chem., 52, 343-8 (p. 347); C. B., II, 453; J. Chem. Soc. London, Abst., 88 , II, 573: 2239 .

1085. Walden, P. Z. physik. Chem., 54, 129-230 (pp. 135-9); C. B. (I906), I, 536-40: $21,2241,224 I$.

1086. Wiley, H. W. Am. J. Pharm., 77, ror; Rev. Am. Chem. Research, 11, 279: II, 6.

*1087. Winkler, L. W. Gyózysz. Közl. Budapest, 21, 650-1, 667-81; Ber. chem. Ges. 38, 36r 2-6; Chem. Rep. 29,374 ; C. B. (1906), II, 1718; Am. Chem. J., 35, 286-7 (1906); Report by J. B. Tingle: 2222, $22221,2233,631113$.

1088. Young, S. Phil. Mag. (6) 9, I-x9 (p. I6); J. chim. phys., 4, 425 (1906): 2227, 2233.

\section{6}

1089. Barlow, P. S. J. Chem. Soc. London, 89, 162-6; C. B., I, $455: 3224,423$.

*1090. Bredig, G. und W. Fraenkel Ber. chem. Ges., 39, 1756-60; C. B., II, ro6: 3273, 6rtz24.

1091. Brown, J. C. J. Chem. Soc. London, 89, 311-3: 23, 2323.

1092. Carrara, G. e G. Ferrari Gazz. chim. ital., 36, I, 419-29: 2I, 2II3, 23, 2313.

1093. Chace, E. M. J. Am. Chem. Soc., 28, 1472-6; C. A., 1, 86 (1907): 61214, 622.

*1094. Crismer, L. Bull. soc. chim. belg., 20, 294-305; C. B. (1907), I, 1068: 21, 2122, 2222, 23, 2322, 61123, $62123,631111,631132,631133$.

1095. Crismer, L. Bull. soc. chim. belg., 20, 382-5; C. B. (1907), I, 1811: 2222, 422, 62123.

1096. Delachanal et Démichel Bull. ass. chim. sucr. dist., 23, 753-62: 73.

1097. Dunlap, F. L. J. Am. Chem. Soc., 28, 395-8; C. B., I, I692; Chem. Rep., 30, I2I: $632111,632112$.

1098. Friderich, L. J. chim. phys., 4, 123-39; Ann. Physik. Beib., 30, 959: 2223.

1099. Getman, F. H. J. chim. phys., 4, 386-564; Fortschr. Phys., I, 428; C. A., 1, 814 (I907): 3226.

*1100. Goldschmidt, H. Atti de VI congreso interzazionale di chimica applicata, 6, 159; Chem. Ztg., 30, 456; Z. Elektrochem., 12, 432: 3273, 61124.

1101. Goldschmidt, H. und E. Sunde Ber. chem. Ges., 39, $711-25$ (p. 712$): 521,5214$.

1102. Guigues, P. J. pharm. chim. (6), 24, 204; Chem. Rep., 30, 422: 6, 636.

1103. Hess, V. F. Sitzb. Akad. Wiss. Wien., 115, IIa, 459-78 (p. 467 ): 32224,3261 .

1104. Holmes, J. J. Chem. Soc. London, 89, II, I774-80; C. A., 1, 390 (1907); C. B. (1907), I, I3: 32 I.

1105. Jones, H. C. and L. McMaster Am. Chem. J., 36, 325-409; C. A., 1, 3 (1907): 21, 2126, $2141,2226$. $224 I, 63 I 132,631145$.

1106. Jones, H. C. and C. A. Rouiller Am. Chem. J., 36, 427-87 (p. 443); C. A., 1, 52I (I907): 2I, $214 I, 2 I 43$, $2241,2243$.

1107. Kailan, A. Sitzb. Akad. Wiss. Wien., 115 (2b) 347; Monatsh., 27, 543-600 (1906); C. B., II, 777 ; Lieb. Ann., 351, 186-217; C. A., 1, I556 (1907): 61124.

1108. Kistiakowsky, W. Z. Elektrochem., 12, 5x3-4: 2225.

*1109. Klason, P. och 'E. Norlin. Arkiv Kemi, Min. Geol. Stockholm, 2, 93; C. B., II, I480; Chem. Rep. 30, 350: $21,2122,21221,2222,63,631113$.

1110. Konek, Fr. von Ber. chem. Ges., 39, 2263-5: 631124.

1111. Menschutkin, B. N. J. Russ. Phys. Chem. Soc., 38, roro-36; J. Chem. Soc. London, Abst., 92, I, $271-3(1907): 423$. 
1112. Passerini, N. Statz. sperim. agrar. ital., 39, 22I-40; C. B., II, I280: 63213.

1113. Renard, Th. et P. Guye. J. chim. phys., 5, 8I-II2; C. B. (I907), I, I478: 2225.

1114. Schmid, A. Chem. Ztg., 30, 608: 6212, 84 .

1115. Thiele, J. und F. Günther. Iieb. Ann., 349, 45-66 (p. 55); C. B., II, I258; Bull. soc. chim. (4), 4,684: 6III5.

*1116. Timmermans, J. Z. Elektrochem., 12, 644-7; C. B., II, I23I; Z. physik. Chem., 58, I29-213 (Bibliography); C. B. (I907), I, I008; C. A., 1, I5I2 (1907): 61123, 62123, 88.

*1117. Timmermans, J. Bull. soc. chim. Belg., 20, 386-4I9; C. B. (1907), I, I478: 2223, 6rr23.

1118. Tischtschenko, W. J. Russ. Phys. Chem. Soc., 38, 355-4I8, 482-539; C. B., II, I309-II, I552-5: 5213.

1119. Tischtschenko, W. and M. Woronkow. J. Russ. Phys. Chem. Soc., 38, 547-50; C. B., II, I556: 5213.

1120. Vandam, L. Bull. soc. chim. Belg., 20, 374-84; C. B. (I907), I, I810: 61123, 62123, 7.

1121. Walden, P. Z. physik. Chem., 55, 207-49 (p. 232-3); C. B., I, I5I9-21: 2226, 2241.

1122. Walden, P. Z. physik. Chem., 55, 28I-302: 2233,425 .

1123. Walden, P. Z. physik. Chem., 55, 683-720; C. B., II, 483-4: 423 .

1124. Wegscheider, R. Ber. chem. Ges., 39, I054-7: 521 .

1125. Whitehouse, N. L. G. and N. C. Beetlestone. Eng. Pat. 4274 (Feb. 2I); Chem. Rep., 31,438 (I907): 6.

\section{7}

1126. Babington, F. W. J. Soc. Chem. Ind., 26, 243; Z. angew. Chem., 21, 505 (1908); C. A., 1, I758: 613.

1127. Battelli, A. Rend. Acc. Lincei (5), 16, I, 243-57; Nuov. Cimento, 13, 418-35; Wied. Ann. Beib., 31, I042; Physik. Z., 9, 67I-5 (I908); C. A., 3,9 (I909); C. B. (I908), I, I488: 2231.

1128. Baume, G. et D. E. Tsakalotos. C. r. acad. sci. Paris, 144, 373-6; C. A., 1, I218: $2227,425$.

*1129. Biltz, W. Ber. chem. Ges., 40, 2182-4; C. A., 2, 47 (I908); C. B., II, 355: 6III45.

1130. Bödtker, E. Z. physik. Chem., 22, 505-14: 423.

1131. Bose, E. Z. physik. Chem., 58, 585-624. I. mit A. Müller (pp. 586-597). II. mit Margaret Bose (pp. 597-624); C. A., 1, 1820: 2231, 3231, 3239 .

*1132. Chappuis, .P. Bur. int. d. Poids Mesures. Trav. et Mem. XIII, D, I-40: 82.

1133. Cheneveau, C. Ann. chim. phys. (8), 12, I45 (pp. I8I, I85, 205); C. A., 2, 505, 2324 (I908): $2222,226 r$.

1134. Cuno, E. Ber. physik. Ges., 5, 735-8; C. A., 2, I22I, 2324 (I908); C. B. (I908), I, $344: 423$.

1135. Denis, W. Am. Chem. J., 38, 56I-94; C. A., 2, 797 (1908); C. B. (I908), I, $344: 521 r$.

1136. Dunstan, A. E., F. B. Thole, and J. S. Hunt. J. Chem. Soc. London, 91, I728-36; Ann. Physik. Beib., 32, 57I (1908): 13, 2226.

1137. Dutoit, P. et P. Mojoïu. J. chim. phys., 7, 169-88 (p. I86): 22IT, 2213, 2225.

1138. Flawitzky, F. J. Russ. Phys. Chem. Soc., 39, 665-6: 2227, 3228, 422.

1139. Fournier, H. C. r. acad. sci. Paris, $144,331-3$; C. A., 1, 1386; C. B., I, II79: 5211.

*1140. Fraenkel, W. Z. physik. Chem., 60, 202-36; C. A., 1, 2850: 3273, 6r124.

1141. Gaillard, L. J. pharm. chim. (6), 26, 48I-7; C. B. (I908), I, 22I; Bull. ass. chim. sucr. dist., 25, 6I0-4; C. A., 2, 934 (1908): 2226 .

1142. Goldschmidt, H. und O. Udby. Z. physik. Chem., 60, 728-55; C. A., 2, 26I (1908): 521,631 .

1143. Hausbrand, E. Z. chem. Apparatenkunde, 2, 586-9I, 6I7-22, 64I-7: 3227, 3228, 87 .

1144. Herrick, R. F. Book, New York: Ir.

1145. Herz, W. und G. Anders. Z. anorg. Chem., 52, I64-72; C. A., 1, 955; C. B., I, 61 7: $41,413,423$.

1146. Herz, W. und G. Anders. Z. anorg. Chem., 55, 27 I-8; C. A., 1, 2856; C. B., II, I 294: 4.

1147. Jones, H. C. and W. R. Veazey. Am. Chem. J., 37, 405-10; C. A., 1, 1356: 2226, 3226.

*1148. Kailan, A. Monatsh., 27, 927-46; C. B., II, I489: 2222, 631132 .

1149. Kazay, E. von. Pharm. Post. 40, 53I-3; C. B., II, 773; C. A., 2, 752 (I908): 2264.

1150. Killing, C. und S. Oppenheimer. Chem. Ztg., 31, I I83; C. A., 2, I372 (I908): 6, 6322.

*1151. Klason, P. och E. Norlin. Arkiv. Kemi Min. Geol. Stockholm, 2, No. 27: 73.

1152. Laar, J. J. van. Z. physik. Chem., 61, 255-6; C. B. (I908), I, 22I; C. A., 2, 500 (I908): 3239.

1153. Lemoine, G. C. r. acad. sci. Paris, 144, 357; C. B., I, I246; C. A., 1, I386: 522.

1154. Morgan, J. L. R. and H. K. Benson. J. Am. Chem. Soc., 29, II76-8; C. A., 1, 2767; Z. anorg. Chem., 55, 356-60: 2211, 2213.

1155. Mueller, P. und R. Abegg. Z. physik. Chem., 57, 513-32; C. A., 1, 812: 43, 433.

1156. Neuberg, C. Sitzb. Akad. Wiss. Berlin, 820; C. A., 2, 2329 (I908): 5213.

1157. Pauli, E. Ann. Physik. (4), 23, $907-3$ I ; C. A., 2, 499 (I908); C. B., II, I582: 2232.

1158. Perkin, F. M. and L. Pratt. Proc. Chem. Soc. London, 23, 304; C. A., 2, 993 (I908); C. B. (I908), I, I610; J. Chem. Soc. I.ondon, 95, I59-65 (I909); C. A., 3, I527 (I909); C. B. (I909), I, I312; Chem. Ztg., 33, 165 (1909): 5213 .

1159. Ritzel, A. Z. physik. Chem., 60, 3 I9-58; C. A., 1, 2972; C. B., II, I825: 22222, $2225,421$.

1160. Schreinemakers, F. A. H. Z. physik. chem., 59, 64I-69: 423.

1161. Smith, A. W. Proc. Am. Acad., 42, 420-60; C. A., 1, I09I: 22222. 
*1162. Timmermans, J. Bull. soc. chim. Belg., 21, 395-402: 2222.

1163. Vesterberg, A. Arkiv. Kemi Min. Geol. Stockholm, 2, No. 37; C. B., II, I328: 423.

1164. Wagner, B. und F. Schulze. Z. anal. Chem., 46, 508-14 (p. 509); C. B., II, 1018: 2222, $62122,63 I I I 3$. 1165. Wiley, H. W. and H. Schreiber. Proc. Am. Phil. Soc., 46, II7-23; C. A., 2, 882, (I908): I4. 1166. Winkelmann, A. Z. physik. Chem., 60, 626-37; C. A., 1, 2968; C. B., II, 2030: $223,323$.

1908

*1167. Andrews, L. W. J. Am. Chem. Soc., 30, 353-60; C. A., 2, 2278; C. B., I, I45I; 2222, 226I, 326I, 6II23, $62123, \sigma_{31113}, 6_{31124}, 6_{31132 .}$

*1168. Bein, W. Wiss. Abh. K. Norm. Eich. Komm., 7, I-42; C. A., 3, 1487 (1909); C. B., II, I994; J. Chem. Soc. London, Abst., 96, I, 80 (I909): 2222, $22221,6,88$.

1169. Blondeau, A. Bull. ass. chim. sucr. dist., 25, 1032-45; 26, 148-60; C. A., 2, 2968, 3380; C. B., II, 728 , I538: $7,72 \pi, 73$.

1170. Bogojawlenskij, A. und V. Humnicki. Z. angew. Chem., 21, r639-46; C. A., 2, 338r; C. B., II, II37: I6, 6, 632 .

1171. Bouveault, L. Bull. soc. chim. (4), 3, I19-24; C. B., I, I375; C. A., 2, I550: 5211 .

1172. Colley, A. R. J. Russ. Phys. Chem. Soc., 40, 12 I-8; C. B., II, 390; C. A., 3, I 718 (I909): 2247, 2249, $22 \sigma_{3}, 3247,3249,3264$.

*1173. Crismer, L. Bull. soc. chim. Belg., 22, 253: 61123.

1174. Doroshevskii, A. and S. Dvorzhanchik. J. Russ. Phys. Chem. Soc., 40, ror-25, 908-3I; C. A., 2, 218r; C. A., 3, I355 (I909); C. B., I, I375-7 and II, I569: 2261, 2322, 2333, 236r, 3261, 63II32, 63II33.

*1175. Doroshevskii, A. and A. Rakovskii. J. Russ. Phys. Chem. Soc., 40, 860-86; C. A.. 3, 1354-5 (I909); C. B., II, I568: 2222, 223I, 224I, 323I, 63I, 63II32.

1176. Doroshevskii, A. and M. Rozhdestvenskii. J. Russ. Phys. Chem. Soc., 40, 887-908; C. A., 3, I355 (I909); C. B., II, I568: 224I, 324I, 631 32.

1177. Duboux, M. et P. Dutoit. Ann. chim. anal., 13, 4-9; C. A., 2, 1853: 62123, 7 .

1178. Dudley, W. L. J. Am. Chem. Soc., 30, I27I-6; C. A., 2, 2840; C. B., II, I469: 625.

1179. Dunstan, A. E. and J. A. Stubbs. J. Chem. Soc. London, 93, 1919-27; C. A., 3, 777 (1909); C. B. (I909), I, 27r: $13,2226$.

1180. Dutoit, P. et H. Rappeport. J. chim. phys., 6, 545-5r; C. A., 3, 269 (I909); C. B., II, I560: 2241 .

1181. Frank-Kamenetzky, A. Chem. Ztg., 32, 569-70; C. B., II, 262: 62122, 7.

1182. Friedrichs, F. Chem. Ztg., 32, 890-1; C. A., 2, 3260; C. B., II. I293: $I I, 6$.

1183. Getman, F. H. J. Am. Chem. Soc., 30, 1077; C. A., 2, 289I: 21, 2122, 2222, 2226.

1184. Gyr, J. Ber. chem. Ges., 41, 4308-22; Habilitationsschrift, Freiburg, Schweiz; C. A., 2, 650: 21 , $2122,2133,3273,51,511,88$.

*1185. Gyr, J. Ber. chem. Ges., 41, 4322-7; C. A., 2, 65I: 2I, 2I22, 2133, 61124, 631113.

1186. Haas, B. Naturwiss. Mitt. Leipzig No. 2: $62125,723$.

1187. Herz, W. und F. Kuhn. Z. anorg. Chem. 58, 159-67; C. A., 2, 2638; C. B., II, 149: $2222,2226,2233$.

1188. Hess, V. F. Sitzb. Akad. Wiss. Wien., 117, IIa, 947-94 (p. 972); Ann. Physik. (4), 27, 589-625; C. B. (1909), I, 25I; C. A., 3, 1243 (1909): 32224, 326r.

1189. Hinkel, L. E. Analyst, 33, 417-9; C. A., 3, 353 (I909); C. B. (I909), I, 46: 613.

1190. Lemoine, G. C. r. acad. sci. Paris, 146, 1360-66; C. B., II, 389-90; C. A., 2, $2687: 522$.

1191. Lemoult, P. Rev. géner. des Sciences, Feb. 29; Bull. ass. chim. sucr. dist., 25, 988: 13, 2239.

1192. Masing, H. Chem. Ztg., 32, 745, 772; C. A., 2, 3177; C. B., II, 991: 3228.

1193. Norm. Eich.-Komm. Berlin Mitth., 3, 26 (May): 721.

1194. Norm. Eich.-Komm. Berlin Mitth., 3, 59 (July): 73.

1195. Pissarjewski, L. und E. Karp. Z. physik. Chem., 63, 257-68; C. A., 2, 3021: 3226.

1196. Race, J. J. Soc. Chem. Ind., 27, 547-8; C. A., 2, 338I; C. B., II, II33: 62I22.

1197. Richards, T. W. and J. H. Mathews. J. Am. Chem. Soc., 30, 8-13; C. A., 2, 74I; Z. physik. Chem., 61, 449-54; C. B., I, 1020: 2222, 22222, 225.

1198. Richards, T. W. and J. H. Mathews. J. Am. Chem. Soc., 30, I282-4; C. A., 2, 2747 ; C. B., II, I48I; Z. physik. Chem., 64, 120-3: 87 .

1199. Rubens, H. und E. Ladenburg. Sitzb. Akad. Wiss. Berlin, $274-84$; II $40-3$; C. B., I, I363; and (I909), I, 635; C. A., 3, I492 (I909); Sitzb. ibid. (I910), Ir36: 2262.

1200. Rühlemann, F. Diss. Jena (p. 45): $2222,42 T$.

1201. Sabatier, P. et A. Mailhe. C. r. acad. sci. Paris, 146, I376-8; 147, 16-8, 106-ro; C. A., 2, 2687, 3057-8; C. B., II, 389, 580, 675-6: 5211 .

1202. Schroeder, J. J. Russ. Phys. Chem. Soc., 40, 360-7; C. A., 3, r838 (r909); C. B., II, $479: 2231$.

1203. Schwers, F. Bull. acad. Belg., 814-54; Rec. trav. chim., 28, 42-65 (I909); C. A., 3, r710 (I909); C. B. (1909), I, 5 I5, I538: 25,35 .

1204. Sendersens, J. Ann. chim. phys. (8), 25, 449-529; C. A., 6, 1607-8 (1912): 522 . 
1205. Timmermans, J. Bull. sóc. chim. Belg., 22, 427-39; C. B. (1909), I, 419; C. A., 3, 86I (1909); 2222. 1206. Tower, O.F. J. Am. Chem. Soc., 30, 1219-28 (p. 1228); C. A., 2, 3013; C. B., II, I329: 21, 2127, $2227,423$. 1207. Traube, I. Chem. Ztg., 32, I226; C. A., 3, 94I (I909); C. B. (I909), I, 322: 6.

1208. Turner, B. B. Am. Chem. J., 40, 558-74; C. A., 3, 506 (I909); C. B. (Iy09), I, 974: 2222, 2241, $2244,5211$. 1209. Vrevskij, M. S. J. Russ. Phys. Chem. Soc., 40, 541-2: 3227, 3228.

1210. Vrevskij, M. S. J. Russ. Phys. Chem. Soc., 40, I778-9: 31, 3127, 3128, 3227, 3228, 33, 3327, 3328.

1211. Walden, P. Z. physik. Chem., 65, 129-225 (pp. 189, 207); C. A., 3, 976 (1909): 2211, 2213, 22221, 2225, 2226.

1909

1212. Bakowski, A. Z. physik. Chem., $65,727-36$ (p. 734); C. A., 3, 2650: 2231, 3231.

1213. Barbet, Buisson, Delachanal et Demichel. Bull. assoc. chim. sucr. dist., 26, 474-8; C. A., 3, r199: 7,73 .

1214. Brandenburg, R. Chem. Ztg., 33, 880; C. A., 3, 3004; C. B., II, 1010: 611144, 6111446, 6rir5, 63II25, 631132.

*1215. Bureau of Chemistry, Department of Agriculture, U. S. A. Circular No. $5^{2}$ (pp. 20-29): 73.

1216. Bureau of Standards, Department of Commerce and Labor, U. S. A. Circular No. ig (Aug.) Standard Density and Volumetric Tables: Revised (July, I9II), including results of present paper: 73 .

*1217. Chappuis, P. Arch. sci. phys. nat. Genève (4), 28, 356-7; Trav. Mem. Bur. Int. Poids et Mesures 14, D, I-93 (I910): 8I.

1218. Delépine, M. et P. Bonnet. C. r. acad. sci. Paris, 149, 39-4I; C. A., 3, 2677; C. B., II, 589, 1632: 6r21I, 632112.

1219. Dobrosserdow, D. J. Russ. Phys. Chem. Soc., 41, I385-I406; C. B. (I9I0), I, 790-2: 2I, 2137, 2145 , $2237,2245,23,2337,2345,25,2537,2545$.

1220. Doroshevskii, A. J. Russ. Phys. Chem. Soc., 41, 958-77; C. A., 4, 1404 (I910); C. B. (I9I0), I, 156: 2I, 2122, 2131, 2133, 23, 2322, 2331, 2333, 3I, 3122, 313I, 33, 3322, 333I.

1221. Doroshevskii, A. and S. Dvorzhanchik. J. Russ. Phys. Chem. Soc., 41, 849-55; Z. physik. Chem., $68,43-8$; C. A., 4, 135, 1403 (1910); C. B., II, 2133: 2261, 3261 .

1222. Doroshevskii, A. and S. Dvorzhanchik. J. Russ. Phys. Chem. Soc., 41, 951-8; C. A., 4, 1404 (1910); C. B. (1910), I, I55: 2I, 2161, 31, 3161.

1223. Doroshevskii, A. and A. Raksovski. J. Russ. Phys. Chem. Soc., 41, 11 10-6; C. B. (I910), I, 157: 2231, $3231,423$.

1224. Doroshevskii, A. and M. Rozhdestvenskii. J. Russ. Phys. Chem. Soc., 41, 977-96; C. A., 4, I405 (1910); C. B. (1910), I, I54: $21,2122,31,3122,631$.

1225. Doroshevskii, A. and M. Rozhdestvenskii. J. Russ. Phys. Chem. Soc., 41, 1428-38; C. B. (1910), I, 81 2: 23, 2322, 33, 3322 .

1226. Duchemin, R. Bull. ass. chim. sucr. dist., 26, 1076-8; J. Chem. Soc. London, Abst., 96, I, 450; C. A., 3, 512 ; C. B., II, 1021: 521 .

1227. Dujardin. Bull. ass. chim. sucr. dist., 26, 645; Chem. Rep., 33, 262: I2.

1228. Dunstan, A. E. and F. B. Thole. J. Chem. Soc. London, 95, 1556-6I; C. A., 4, 402 (1910); C. B., II, 1979: $13,2226,3226$.

1229. Euler, H. und B. af Ugglas. Arkiv Kemi Min. Geol. Stockholm, 3, No. 21; Chem. Rep., 34, 69 (19ro); C. A., 4, 980 (1910): 3273 .

1230. Findlay, A. Z. physik. Chem., 69, 203; C. A., 4, 534 (I9I0): $21,2222,2226,422,63 I 113,63 I 132$.

1231. Fontein, F. Diss. Delft; Z. physik. Chem., 73, 212-5I (I9I0) (p. 2I2); C. A., 4, 2229 (I9I0): C. B. (I9I0), II, 267-8: 21, 2122, 631113, 631145 .

1232. Holmes, J. and P. J. Sageman. J. Chem. Soc. London, 95, I919-43 (p. I936); C. B. (I9I0), I, 319: C. A., 4, 699 (1910): $21,2122,2133,2222,2233,23,2322,2333$.

1233. Jones, H. C. and E. C. Mahin. Am. Chem. J., 41, 433-42; C. A., 3, 1958; Z. physik. Chem., 69, 389-418; C. A., 4, 401 (1910): 2I, 2I26, 214I, 2226, 224I, 3I, 3I26, 3I4I, 3226, 324I, 4I, 4I2, 422 .

1234. Jones, H. C. and M. B. Schmidt. Am. Chem. J., 42, 37-95: 2226, 2241, 24, $2426,2441$.

1235. Kailan, A. Z. Elektrochem., 15, ro6-10; C. A., 3, II72 (1909): 3273, 521, 61124.

1236. van Laar, J. J. Archiv. Arusee Teylèr (2), 11, 235-33r: 2213, 3239.

1237. Lippmann, E. O. von. Chem. Ztg., 33, $1233: 12$.

1238. Maihle, A. Chem. Ztg., 33, 18, 29; C. A., 3, 1013: $5211,522$.

1239. Mastbaum, H. ;th Inter. Cong. App. Chem., London; Chem. Ztg., 33, 626; Rev. soc. hyg. aliment., 7, 241-52 (1910); C. A., 4, 809 (1910): 624,7I.

1240. Norm. Eich.-Komm. Berlin, Mitth., 3, r18 (Oct.): 73.

1241. Pascal, P. Bull. soc. chim. (4), 5, 1061-9, II10-8 (p. 1065 and III3); C. A., 4, 755 (I910); C. B. (1910), I, 246, 807: 13, 2251 .

1242. Plato, F. Tafeln, $3^{\text {te }}$ Auflage, Berlin: 73 . 
*1243. Plücker, W. Z. Nahr. Genuss., 17, 454-8; C. A., 3, 2032; C. B., I, 1973; Chem. Rep., 33, 425: II, $423,611113,611124,611125,611132,611133,612,613,614,615,616,619,631113,631124,631125,631132$, $631133,632,633,635,636$.

*1244. Pozzi-Escot, E. Bull. assoc. chim. sucr. dist., 26, 580; C. A., 3, 1 199; C. B., I, I229: 631125, 86.

1245. Rapeller, H. D. R. P., 213,259 (Mch. 25); C. B., II, r023; C. A., 4, 1648 (r910): 62125, $624,7$.

1246. Richards, T. W. and J. H. Mathews. J. Am. Chem. Soc., 31, 1200-2; C. A., 4, 266 (I910): 87.

1247. Ruttan, R. F. J. Soc. Chem. Ind., 28, 1290-4; C. A., 4, 637 (1910): 14.

1248. Schreinemakers, F. A. H. und W. C. de Baat. Z. physik. Chem., 67, 55I-60; C. A., 4, 268 (I9I0); C. B., II, I622: 423 .

1249. Schwers, F. Rec. trav. chim., 28, 26I-6; C. A., 3, 2895; C. B., II, 970: 3222.

1250. Senderens, J. C. r. acad. sci. Paris, 148, 227; Bull. soc. chim. (4), 5, 450 and 480-6; C. A., 4, 755 (I9 10); C. B., I, 908, 1974; Ann. chim. phys. (8), 25, 449-529 (I9I2); C. B. (1912), I, I887: $5211,522$.

1251. Siebenrock, E. von. Monatsh., 30, 759-66; C. A., 4, I400 (I910); C. B. (I910), I, I228: 63I.

*1252. Timmermans, J. Bull. soc. chim. Belg., 23, 433-59; C. B. (1910), I, 320; C. A., 4, 855 (I9ro): 422, 61123,62123 .

1253. Vorisek, A. J. Soc. Chem. Ind., 28, 823-5; C. A. 3, 2922 (I909); C. B., II, I083; Chem. Rep., 33, $489: 613$.

1254. Wade, J. and H. Finnemore. J. Chem. Soc. London, 95, 1842-54; C. A., 4, 702 (I910); C. B. (I910), I, 249: 425,6 .

1255. Wasilewski, G. Diss. Münster i. W.: 22221.

1256. Wibaut, J. Chem. Weekblad., 6, 40I-9; J. Chem. Soc. London, Abst., 96, II, 558; C. A., 3, 2769 ; C. B., II, 2124: 423 .

*1257. Acree, S. F. and students. Private communication, July also Jan., I913: 2222, 2241, 61124,631113 , 631132,631144 .

1258. Baudrexel, A. Wochsch. Brau., 38, 47I-3, 486-9; C. B., II, I326: 624, 7.

1259. Beaulard, P. C. r. acad. sci. Paris, 151, 55-7; C. A., 4, 316r; C. B., II, 966; J. Chem. Soc. London, Abst. 98, II, 680: 2245, 2246.

1260. Beaulard, F. et L. Maury. J. de phys. (4), 9, 39-43: 2245, 2246, 3245, 3246.

1261. Berthelot, D. et H. Gaudechon. C. r. acad. sci. Paris, 151, 478-8I* C. B., II, I285; J. Chem. Soc. London, Abst., 98, I, 814; C. A., 5, 2629 (I9II): 524 .

1262. Bingham, E. C. Am. Chem. J., 43, 306: 321, 3226.

1263. Borde, G. U. Chem. News, 102, 4I-2; C. A., 4, 2874: 14, 15.

1264. Bugarsky, S. Z. physik. Chem., 71, 705-59 (p. 749); C. A., 4, 1407: 2213, 3273

1265. Bureau of Chemistry, Department of Agriculture, Bull. No. Io7 (rev) Washington, U. S. A. Official and Provisional Methods of Analysis, Association of Official Agricultural Chemists: $61,62,63,73$

1266. Dawson, H. M. J. Chem. Soc. London, 97, I04I-56; C. B., II, 268-9; C. A., 4, 2062: 21 , $2122,2222$.

1267. Denigès, G. C. r. acad. sci. Paris, 150, 832-4; C. A., 4, I725; C. B., I, I992; J. Chem. Soc. London, Abst., 98, II, 46r: 613,623.

1268. Denigès, G. Bull. soc. chim. (4), 7, $95 I^{-2}$; C. B., II, I949; J. Chem. Soc. London, Abst., 98 , II, III5; C. A., 5,353 (I9II), :614, 624.

*1269. Doroshevskii, A. and E. Polianski. J. Russ. Phys. Chem. Soc., 42, I09-34; C. B., I, I228; Z. physik. Chem., 73, 192-9; C. A., 4, 2224: 21, 2122, 2127, 2133, 2222, 2227, 2233, 23, 2322, 2327, 2333, 31, 3127, $3133,3227,3233,33,3327,3333$.

1270. Doroshevskii, A. and E. Polianski. J. Russ. Phys. Chem. Soc., 42, 1448-52; C. B., (I9II), I, $465-6$ : $2333,3333$.

1271. Doroshevskii, A. and M. Rozhdestvenskii. J. Russ. Phys. Chem. Soc., 42, 442-52; C. B., II, 72; C. A., 5, 410 (I9II): 32225 .

1272. Drucker, K. Z. physik. Chem., 74, 6r2-8 (p. 6I6): $2211,425$.

1273. Drucker, K. und G. Ullmann. Z. physik. Chem., 74, 567-6II (p. 597): 222I, $63 I I I I$.

1274. Fawssett, T. Pharm. J. (4), 30, 754-7; C. B., II, 635; J. Chem. Soc. Iondon, Abst., 98, I, 533-4; C. A., 5,1437 (I III): 321,422 .

1275. Foote, H. W. J. Am. Chem. Soc., 32, 618-22; C. A., 4, 1952: 423, 631111, 631145, 65.

1276. Frank-Kamenetsky, A. Z. angew. Chem., 23, 293-30I; C. A., 4, 2975: 62121, 62122, 721.

1277. Goldhammer, D. A. Z. physik. Chem., 71, 577-624 (p. ú15); C. A., 4, I252: 2213, 2223.

1278. Horiba, Shinkichi. J. Tok. Chem. Soc., 31, 922; Mem. Kyoto College, Japan, 3, $63-76$ (I9II); C. B. (I9II), II, 437 ; C. A., 5, 2770 (I9II): $3222,3226,3261,422$.

1279. Jïptner, H. von. Z. physik. Chem., 73, I73-9I, 343-82; C. A., 4, 2224; C. B., II, 540: $2227,2237$.

1280. Klein, F. J. Ind. Eng. Chem., 2, 389; C. A., 4, 3053; C. B., II, I78I: 613, 6I4, 64 .

1281. Kremann, R. Monatsh., 31, 245-74; C. A., 4, 2404; C. B., II, 443: 422, 5214.

1282. Kremann, R. Monatsh., $31,275-84$; C. A., 4, 2404; C. B., II, 443: 422,5214 
1283. Kremann, R. Monatsh., 31, 671-85; C. B., II, I59I; C. A., 4, 2404: 3273, 422, 5214.

1284. M'Intosh, J. G. Chem. News., 101, 275: 2222.

1285. Marschalk, C. Ber. chem. Ges., 43, 641-2; C. B., I, I226; C. A., 4, 1307, 2806: 6213, 631113.

1286. Meldola, R. J. Soc. Chem. Ind., 29, 737-40; C. A., 4, 3071; C. B., II, 790: 12, 14 .

1287. Merczyng, H. Ann. Physik. (4), 34, I015-25; C. B., II, I4; C. A., 5, 2594 (I9II): 2247.

*1288. Millar, W.S. Diss. Heidelberg (p. 15): 3273, 61124, 62124, 631113 .

1289. Mills, J. E. and D. MacRae. J. Am. Chem. Soc., 32, $1162-76$ (p. II 70 ); C. B., II, I793; C. A., 5, I0 (I9II): 2225.

1290. Pascal, P. Ann. chim. phys. (8), 19, 5 (p. 30); (8), 25, 289-377 (I9I2) (p. 344): 2251.

1291، Philip, J. C., and H. R. Courtmann. J. Chem. Soc. London, 97, 1267: 21, 214I, 224I.

1292, Polowzow, V. Z. physik, Chem., 75, 513 (p. 520); C. A., 5, IOI2 (I9II): 2222, 2225.

1293. Rappenecker, K. Z. physik. Chem., 72, 695-22; C. A., 4, 2593; C. B., II, 62-3: 2226.

1294. Robertson, J. H. C. Diss. Johns Hopkins Univ. confer reference 1257.

*1295. Röhrs, F. Diss. Rostock; Ann. Physik. (4), 37, 289-329 (I9II): C. B. (I9I2), I, 974: 2213, 2222, 2261.

1296. Ronnet, L. Ann. fals., 3, 205-6; C. A., 4, 2862; C. B., II, 50r; J. Chem. Soc. London, Abst., 98, II, $66_{3}: 622$.

1297. Sabatier, P. et A. Mailhe. C. r. acad. sci. Paris, 150, 823-6; Ann. chim. phys. (8), 20, 282-352; C. B., I, 1921; J. Chem. Soc. London, abst., 98, I, 606; C. A., 4, 2094: 521, 522.

1298. Saporta, A. de. Bull. soc. chim. (4), 7, 70-1; C. A., 4, 947; C. B., I, 1056: 7.

1299. Schmidt, E. W. Z. physik. Chem., 75, 305-36 (p. 310): 2233, 2241, 631132.

1300. Schreinemakers, F. A. H. Chem. Weekblad., 7, 21 I-6; C. B., I, 1316; C. A., 5, 818 (1911): 423, 631145.

1301. Schwalbe, C. G. Z. angew. Chem., 23, 1537-40; Dingl. Poly. J., 325, 750: C. A., 5, I96 (I91 I): I4, I5.

1302. Schwers, F. Rec. trav. chim., 29, 340-9; C. B. (I9II), I, 449; Z. physik. Chem., 75, 357-64 (I9II); Bull. soc. chim. (4), 7, 875-82; C. B., II, I582; C. A., 5, 14, 613 (I9II): 3222, 3261 .

1303. Schwers, F. Rec. trav. chim., 29, 350-4; C. B. (I9rI), I, 449; Z. physik. Chem., 75, 365-8 (rgrr); Bull. soc. chim. (4), 7, 937-40; C. B., II, 1793; C. A., 5, 613-4 (I9II): 3222, 32221.

1304. Schwers, F. Bull. soc. chim. (4), 7, ro72-7; Rec. trav. chim., 30, 10I-7 (IgII); C. A., 5, 814 (I9II): 3222,3253 .

1305. Schwers, F. J. chim. phys., 8, 630-97; 9, 15-100(I9II); C. B. (I9II), I, 450: 3222, 326 I.

1306. Sidersky, D. Bull. ass. chim. sucr. dist., 27, 562-3; C. A., 4, 1648; Ann. chim. anal. appl., 15, 105-6; C. B., I, 1809; C. A., 4, 1793: 624,7 .

1307. Sidersky, D. Bull. ass. chim. sucr. dist., 27, r168-9; C. B., II, 636; C. A., 4, 2759: 326r.

1308. Smits, A. and H. L. de Leeuw. Diss. Amsterdam; K. Akad. Wetsch. Amsterdam Wisk. Natk. Afd., 19, 283-93; C. B., II, Irir; Proc. k. Akad. Wetsch. Amsterdam., 13, I, 329-4I (I9I2); C. A., 5, I862 (I9II): $2222,422,521$.

1309. Thole, F. B. J. Chem. Soc. Iondon, 97, 2596-2606 (pp. 2600, 2602); C. A., 5, I599 (I911): 2213, 2222, $2226,631113$.

*1310. Timmermanns, J. Bull. soc. chim. Belg., 24, 244-69; C. A., 4, 2896; C. B., II, 442: 21, 2122, 2122I, $2322,23221,6$.

1311. Treasury Department, U.S. A. Washington. (Mch.) Internal Revenue Gauger's Manual; embracing regulations, instructions, and tables: 7,73

1312. Tumlirz, O. Sitzb. Akad. Wiss. Wien., 119, IIa, 393-417: 3222, 32224, 3225.

1313. Tyrer, D. J. Chem. Soc., London, 97, 626-3I: 4I, 4I3, 423, 63IIII, 63 II 45 .

1314. Utz. Z. anal. Chem., 49, 453: 23, 236r.

1315. Vaillant, P. C. r. acad. sci. Paris, $150,213-6$ (p. 215): 2227.

1316. Vandevelde, A. J. J. Bull. soc. chim. Belg., 24, 432-5: 6 .

1317. Vivencio del Rosario, M. Philipp. J. Sci., 5A, 29; C. A., 4, $2709: 622$.

1318. Vrevskij, M. S. J. Russ. Phys. Chem. Soc., 42, I-35; C. B. (I910) I, I959-6r; C. A., 5, I423 (I9II): $321,3227$.

1319. Vrevskij, M. S. J. Russ. Phys. Chem. Soc., 42, 702-I4; C. B. (IgII), II, II92; C. A., 5, 3747 (I9Ir): 3228.

1320. Vrevskij, M. S. J. Russ. Phys. Chem. Soc., 42, 1349-55; C. B. (I9II), II, Ir93-4; C. A., 5, 2016 (I9II); J. Russ. Phys. Chem. Soc., 43, 1446-57 (I9II); C. B. (I9I2), I, 392: 3228, 3233.

1321. Walden, P. Z. physik.Chem., 70, 569-619 (p. 573); C. A., 4, 1258: 2245.

*1322. Warren, W. H. J. Am. Chem. Soc., 32, 698-702; C. B., II, I25-6; C. A., 5, 3 (1911): 2222, 6r3312, 87. 1323. Wolff, H. Chem. Ztg., 34, I193: 62, 627.

*1324. Young, S. Proc. Dublin Soc. (N.S.), 12, 374-443 (pp. 388, 44r); Z. physik. Chem., 70, 620-6; C. A., 4, 1564; C. B., I, 1481-2: 2I, 222 $3,2222,2223,2237,23$. 


\section{1}

1325. Armstrong, H. E. and F. P. Worley. Chem. News., 103, I45; C. B., I, 507; C. A., 5, $2355: 3273$.

1326. Bacon, R. F. Bur. Chem. Circular No. 74 (I9II); C. A., 5, 2873: 613, 6I4, 623, 624.

1327. Berthelot, D. et H. Gaudechon. C. r. acad sci. Paris, 153, 383-6; C. B., II, ror6-7; C. A., 5, $2629: 524$. 1328. Birstein, G., H. Denneler und A. Heiduschka. Z. angew. Chem., 24, 2429-30: 6, 87.

*1329. Braune, H. Diss., Heidelberg: $3273,61124,62124,631113$.

1330. Cederberg, I. W. J. chim. phys., 9, 3-I4; C. B., I, 527; C. A., 5, 2016: 2222, 2225, 423.

1331. Doroshevskii, A. J. Russ. Phys. Chem. Soc., 43, 46-66; C. B., I, I407-8; C. A., 6, 9 (I9r2): 2213.

1332. Doroshevskii, A. J. Russ. Phys. Chem. Soc., 43, 656-70; C. B., II, 420; C. A., 6, I79 (I9I2): 3222 , 3227.

1333. Doroshevskii, A. J. Russ. Phys. Chem. Soc., 43, 962-73; C. B., II, 1899; C. A., 6, $3 I_{5}$ (19I2): 3227.

1334. Duperthuis, H. und E. Philippe. Mitt. Lebensmittelunters. U. Hyg., 1, 188-93; C. B., I, I255; C. A.; $5,3 I_{3}: 61123,62123,7$.

1335. Foote, H. W. and S. R. Scholes. J. Am. Chem. Soc., 33, I309-26 (pp. I3II, I321, I324): C. B., II, I405; C. A., 5, 3189: 3227, 423 .

1336. de Forcrand. C. r. acad. sci. Paris, 153, I44I-4; C. A., 6, 860 (I9I2): 5213.

1337. Goldschmidt, R. Physik. Z., 12, 4I7-24; C. B., II, 344; C. A., 5, 2767: 2232.

1338. Griesheim-Elektron, Chemische Fabrik, Frankfurt a. M. D. R. P. 23659x; C. B., II, 3 I3: 63115.

1339. Hardman, R. and A. Lapworth. J. Chem. Soc. London, 99, 2242-53; C. A., 6, I565 (I9г2); C. B. (I912), I, 702: 224, 324 .

1340. Jones, W. J. and A. Lapworth. J. Chem. Soc. London, 99, 1427-32: 422.

*1341. Kailan, A. Ber. chem. Ges., 44, 288I-4; C. B., II, I72I; C. A., 6, 232 (1912): 2222, 3273, 61124, 62124. $63 I I I 2,63 I I I 3$.

1342. Kreider, H. R. and H. C. Jones. Am. Chem. J., 45, 28I-324 (p.297); C. B., I, I34I; C. A., 5, I700; $2 I, 214 I, 224 I, 2244,425$.

1343. Kreider, H. R. and H. C. Jones. Am. Chem. J., 46, 574-85; C. A., 6, 823 (I912): C. B. (I912), I, 545: $2 I, 2 I 4 I, 224 I$.

1344. Lapworth, A. and J. R. Partington. J. Chem. Soc. London, 99, I4I7-27: 224.

1345. McDaniel, A. S. J. Physic. Chem., 15, 587-6ro; C. B., II, 666; C. A., 5, 3529: 421.

1346. Magini, R. Atti R. Accad. Lincei (5), 20, I, 30-7; C. B., I, ro24; C. A., 5, $2766: 3225$.

1347. Mariller, C. Bull. ass. chim. sucr. dist., $28,473-90,537-59$; C. B., I, II $84-5$, C. A., 5, $2015: 3228$.

1348. Mariller, C. Bull. ass. chim. sucr. dist., 28, 768-70; C. B., I, I785; C. A., 5, 2455: 3223.

1349. Mathews, J. H. J. Am. Chem. Soc., 33, r29r-309 (p. 1292); C. A., 5, 3r89: 223.

1350. Morgan, J. L. R. and A. M. McAfee. J. Am. Chem. Soc., 33, I275-90; C. B., II, I405; C. A., 5, 3 I86: $21,2125,2225$.

1351. Niven, C. Proc. Roy. Soc. Iondon. A, 85, 139-45; C. B., I, I780: 2245.

1352. Partington, J. R. J. Chem. Soc. London, 99, I937-4I; C. A., 6, 566 (r912): 2241, 421.

1353. Paschki, N. J. Russ. Phys. Chem. Soc., 43, Phys. Div. I66-84; C. B., II, I InI: $2231,3231$.

1354. Sutherland, W. Phil. Mag. (6), 22, 17-66; C. B., II, I405; C. A., 5, 3 I87: 2213, $321,32224$.

1355. Thibaut, R. Ann. Physik. (4), 35, 347-77; C. B., II, 427 ; C. A., 6, 6 (I9I2): 2231.

1356. Timmermans, J. Bull. soc. chim. belg., 25, 300-27; C. B., II, Ior 5: 2133, 2134, $2233,2234$.

1357. Vandevelde, A. J. J. Bull. soc. chim. belg., 25, 210-6; C. B., II, 484: 423, 62123.

1358. Wade, J. and R. W. Merriman. J. Chem. Soc. London, 99, 997-rorr; C. A., 5, 2996: 3233.

\section{2}

1359. Adams, A. B. J. Ind. Eng. Chem., 4, 8-14; C. A., 6, 666; C. B., I, 1405: 6, 87.

1360. Archibald, E. H. and W. A. Patrick. J. Am. Chem. Soc., 34, 369-75; C. A., 6, 1563: 2241, 522, 525, 631132,631145 .

1361. Biron, E. J. Russ. Phys. Chem. Soc., 44, 65-III (p. 92-5): 22222.

1362. Campbell, N. Phil. Mag. (6), 23, 668-70; C. B., I, I992: 2241, 422.

1363. Faust, O. Z. physik. Chem., 79, 97-I23; C. B., I, I419: 21, 2126, 2127, 2226, 2227, 2326, 2327, 88.

*1364. Fresenius, W. und L. Grïnhut. Z. anal. Chem., 51, I23-4; C. B., I, 948: 73.

1365. Garver, M. M. J. Physic. Chem., 16, 234-48 (p. 248): 2I, 2IIT, 2I2I, 2I22, $2125,2212,2221,2222,2225$.

1366. Kailan, A. Z. anal. Chem., 51, 8I-I0r; C. A. 6, 232: 24, 2422, 422, 44, 442

1367. Körber, F. Nachr. Ges. Wiss. Göttingen, I-30; C. B., I, I274: 2222, 22221.

1368. Kuenen, J. P. Akad. Wet. Amsterdam Wisk. en Nat. Afd., 20, 725-30; C. B., I, 1290: 422.

1369. Lippmann, E. O. von. Z. angew. Chem., 25, II79-80, 1680-2: I2.

1370. McKee, R. H. J. Ind. Eng. Chem., 4, 46; C. A., 6, 558: 631, 87 .

$77398^{\circ}$-I3 - IO 
1371. Richards, T. W. and J. W. Shipley. J. Am. Chem. Soc., 34, 599-603: 62121, 62125, 7, 722.

1372. Rosenthaler, L. Chem. Ztg. 36, 830; C. A. 6, 3251: 613, 614, 615 .

1373. Sander, W. Z. physik. Chem., 78, 513-49; C. A., 6, 954; C. B., I, 717: 421 .

1374. Vandevelde, A. J. J. Bull. inst. sup. brasserie, Gand, 18, 5-13; Bull. soc. chim. Belg., 25, 368 (19rI), 2e Congres de Alimentation: $7 I$.

1375. Wieland, H. Ber. chem. Ges., 45, 484-93; C. B., I, 994-5: 521.

\section{3}

*1376. Osborne, N. S., E. C. McKelvy and H. W. Bearce. Bull. Bur. Standards. 9, 327-474; Preliminary Notices: Science, 32, 483 (I9I0); Proc. Am. Chem. Soc. (I9II), 66; J. Acad. Sci. Washington, 2, 95-8; C. A., 6, 1085: 2222, 22221, 22223, 3222, 32221, 6III44, 6III45, 6IIIII, 6II23, 61214, 62123, 63III3, 63II25, $631132,631133,632112,632122,6322,73,83,84,86,88$.

[UNCLASSIFIED: 1377. Roscoe and Schorlemmer. Treatise on Chemistry, Vol. III, Part I, p. 297-9, Alcohol; p. $300-20$, Alcoholometry: $I I, 7$. 1378. Wurtz, Ad. Dictionaire de chimie pure et appliquée Tome I, p. 105-33, Alcool, p. 133-6; Alcoométrie: 11.7 .]

\section{DECIMAL CLASSIFICATION OF SUBJECTS}

1 General

11 General Treatises and Articles 33, 49, 51, 134, 255, 275, 298, 334, 386, 407, 441, 444, 546, 547, 668, 862, 880, $883,903,904,971,1086,1144,1182,1243,1377,1378$.

12 History 66, 602, 910, 1227, 1237, 1286, 1369.

13 Constitution 3, 74, 206, 333, 343, 431, 492, 584, 643, 718, 719, 819, 889, 1136, 1179, 1191, $1228,1241$.

14 Synthesis 222, 223, 224, 230, 233, 262, 276, 278, 867, 872, 935, 965, 969, 983, 1008, 1018, 1038, 1070, 1080 $1165,1247,1263,1286,1301$.

15 Preparation 177, 181, 262, 386, 521, 544, 571, 705, 732, 876, 880, 1263, 1301.

16 Alcoholic fermentation 25, 260, 323, 1036, 1068, 1079, 1170.

Physical Properties 62, 77, 92, 93, 138, 145, 333, 911, 925, 960, 976, 988, 996. of Methyl Alcohol 65, 199, 248, 269, 322, 354, 359, 362, 395, 424, 437, 457, 492, 504, 517, 563, 572, 599a, $609,620,622,646,649,651,666,668,704,757,779,784,791,796,890,909,932,933,939,949,958,970$, $992,993,1033,1034,1043,1063,1075,1085,1092,1094,1105,1106,1109,1183,1184,1185,1206,1219$, $1220,1222,1224,1230,1231,1232,1233,1266,1269,1310,1324,1342,1343,1350,1356,1363,1365$. of Ethyl Alcohol 668.

Physical Constitution

Molecular Weight 376, 412, 749, 1137, 1154, 1211, 1272.

Molecular Constants 608, 805, 1365.

Molecular Aggregation. Association and Dissociation 463, 507, 585, 618, 672, 673, 695, 709 , $718,728,736,740,749,787,805,819,826,865,868,871,875,882,889,891,906,936,999,1012$, $1014,1041,1048,1072,1137,1154,1211,1236,1264,1277,1295,1309,1331,1354$.

Density and Specific Volume of Vapor $132,172,338,372,393,413,458,561,580,728,787$, $1273,1324,1365$.

Density and Specific Volume of Liquid $2,4,5,9,10,11,17,25,27,32,38,41,48,52,53,54$, $75,79,83,84,90,92,93,97,102,109,128,132,137,152,154,155,165,168,172,188,199,207$, $225,231,234,237,245,247,254,260,283,285,305,312,322,326,332,333,338,343,347,350$, $359,362,364,393,400,405,408,411,413,414,431,433,438,445,449,453,457,462,463,468$, $486,512,527,531,549,553,563,564,578,579,580,581,584,585,588,607,609,622,645,646$, $651,659,679,684,692,717,741,755,759,780,788,810,818,832,837,860,889,909,920,931$, $933,948,959,966,986,1033,1083,1087,1094,1095,1109,1133,1148,1162,1164,1167,1168$, $1175,1183,1187,1197,1200,1205,1208,1230,1232,1257,1266,1269,1284,1292,1295,1308$, $1309,1322,1324,1330,1341,1365,1367,1376$.

Change with Temperature. Thermal Expansion 2, 4, 5, 26, 46, 47, 52, 75, 84, 92, 93, $137,154,172,207,220,237,247,305,326,347,378,400,417,420,429,438,445,468,484$, $496,527,549,564,607,645,684,717,755,797,933,1033,1087,1109,1168,1211,1255$, $1367,1376$.

Change with Pressure. Compressibility 40, 103, 235, 237, 265, 409, 411, 446, 495, 566, $567,619,654,680,928,936,1159,1161,1197,1361$. 
Physical Properties-Continued.

of Ethyl Alcohol-Continued.

Mechanical Properties-Continued.

2223

2224

Critical Phenomena. Corresponding States 251, 302, 340, 342, 346, 390, 392, 404, 426, 429, $458,490,505,579,652,654,726,728,742,755,805,827,871,921,963,1000,1017,1041,1055$, $1098,1117,1277,1324$.

Diffusion and Osmotic Pressure 401, 436, 462, 616, 960.

Surface Tension $61,91,146,157,158,190,192,237,240,267,312,332,352,393,451,463,470$, $479,480,481,482,496,509,532,553,606,629,644,662,672,673,818,896,961,966,1108,1113$, $1137,1159,1211,1289,1292,1330,1350,1365$.

Viscosity and Fluidity $72,94,169,268,328,331,394,395,427,453,473,476,480,481,584,605$, $643,677,718,766,881,947,1002,1014,1025,1035,1043,1075,1105,1121,1136,1141,1147$, $1179,1183,1187,1197,1211,1228,1230,1233,1234,1293,1309,1363$.

Vapor Pressure and Evaporation 132, 133, 154, 176, 228, 340, 371, 372, 401, 404, 412, 427, 445, $477,507,508,540,567,596,624,665,724,728,848,893,1088,1128,1138,1206,1269,1279,1315$.

Thermal Properties 99, 179, 503, 506, 628, 822, 1166, 1349.

Specific Heat 75, 104, 179, 220, 237, 332, 376, 426, 445, 528, 548, 557, 894, 1003, 1065, 1127, 1131, $1175,1202,1212,1223,1353,1355$.

Thermal Conductivity $361,403,852,1157,1337$.

Boiling Point 37, 79, 82, 83, 84, 92, 128, 137, 151, 154, 172, 199, 231, 237, 406, 445, 448, 462, 488, $492,531,585,622,670,725,730,741,832,844,861,884,890,897,899,948,959,1034,1087$, $1088,1122,1187,1232,1269,1299,1356$.

Melting Point 24, 48, 58, 80, 81, 112, 416, 580, 660, 754, 767, 850, 892, 932, 1013, 1073, 1356.

Ignition Temperature 898, 977.

Point of Calefaction 990.

Heat of Vaporization $67,85,426,450,601,650,664,704,730,774,854,991,1048,1219,1279$, 1324.

Heat of Fusion.

Heat of Combustion or Formation 478, 636, 1010, 1084, 1191.

Electrical Properties 699, 838, 846, 917, 976, 1044, 1063, 1339, 1344 .

Electrical Conductivity $243,296,316,321,369,387,394,435,443,455,456,466,491,527,562$, $568,637,649,651,657,658,701,710,722,723,734,810,815,828,837,839,843,881,914,937$, $941,946,959,962,967,970,996,1007,1014,1023,1026,1039,1043,1054,1075,1085,1105,1106$. $1121,1175,1176,1180,1208,1233,1234,1257,1291,1299,1342,1343,1352,1360,1362$.

Ionic Dissociation 491, 690, 701, 843, 996.

Ionic Velocities $689,700,758,798,946,962,1106$.

Dissociative Power 690, 843, 882, 887, 888, 914, 937, 939, 1026, 1208, 1342.

Dielectric Constant $573,621,694,706,719,739,781,792,802,803,810,815,840,868,879,882$, $930,963,1219,1259,1260,1321,1351$.

Electrical Absorption 803, 1259, 1260.

Electrical Dispersion 761, 842, 856, 1172, 1287.

Electrical Reflection 760.

Electrical Refraction 760, 769, 1172.

Magnetic Properties 529.

Magnetic Behavior 114, 915, 1241, 1290.

Magnetic Susceptibility 514, 849.

Electro-magnetic Rotation of the Plane of Polarized Light 431, 457, 609, 676, 748, 949.

Optical Properties.

Refractive Index $69,86,128,147,170,188,199,227,234,245,322,343,350,364,411,414$, $432,442,449,531,563,569,581,588,609,620,646,659,692,741,751,788,832,909,989$, $1133,1167,1174,1221,1295$.

Reflecting Power 1199.

Absorption 597, 626.

Absorption Spectra 322, 819, 1149, 1172.

Dispersion 188, 199, 234, 245, 322, 350, 405, 408, 414, 449, 531, 578, 609, 646, 909.

Miscellaneous.

Velocity of Sound in Vapor 145, 472, 561, 984.

Velocity of Sound in Liquid 108, 145, 533.

of Higher Saturated Monohydric Aliphatic Alcohols 362, 382, 388, 395, 418, 419, 424, 437, 492, 599a, $649,661,704,711,721,727,730,748,873,933,949,970,1033,1043,1091,1092,1094,1174,1219,1220$, $1225,1232,1269,1270,1310,1314,1324,1363$.

of the Saturated Polyhydric Aliphatic Alcohols 1234, 1366.

of the Unsaturated Alcohols 327, 388, 424, 437, 992, 1203, 1219. 
Physical Properties of Alcohol-Water Mixtures 301, 671, 716.

of Methyl Alcohol-Water Mixtures 144, 269, 314, 362, 511, 517, 663, 809, 987, 1011, 1043, 1210, 1220, $1222,1224,1233,1269$.

of Ethyl Alcohol-Water Mixtures 144, 987.

Physical Constitution 498, 499, 500, 594, 1021, 1104, 1262, 1274, 1318, 1354.

Mechanical Properties.

Density and Specific Volume of Mixed Vapors 132.

Density and Specific Volume of Mixed Liquids 4, 5, 20, 59, 64, 84, 90, 105, 115, 132, 144, $152,154,155,165,168,207,216,237,242,245,247,305,326,374,400,433,438,445$, $498,499,500,583,639,645,684,692,759,780,834,918,931,948,1022,1249,1278$, $1302,1303,1304,1305,1312,1332,1376$.

Change with Temperature. Thermal Expansion 4, 5, 20, 46, 47, 84, 115, 154, 207, $216,237,247,305,313,326,400,438,445,639,645,684,780,1303,1376$.

Change with Pressure. Compressibility 40, 430, 566, 593, 804.

Change with Absorption of Gases 469.

Volume Change on Mixing. Theory of Contraction 44, 91, 132, 242, 425, 581, 1064, $1103,1188,1271,1312,1354$.

Critical Phenomena 302, 357, 702, 859.

Osmotic Behavior 401, 1060, 1089.

Surface Tension 190, 192, 208, 237, 267, 339, 352, 460, 461, 480, 591, 644, 770, 818, 916, 1312 1345.

Viscosity and Fluidity $72,169,268,394,473,480,558,772,1025,1035,1043,1099,1147,1195$, $1228,1233,1262,1278$.

Vapor Pressure and Evaporation 19, 29, 56, 130, 132, 133, 150, 154, 176, 193, 217, 301, 371, $401,445,596,610,703,929,1005,1019,1143,1209,1210,1269,1318,1332,1333,1335$

Vapor Composition and Theory of Distillation $31,34,36,60,95,130,184,186,189,191,212$, $258,280,307,336,353,384,447,539,678,714,812,978,1005,1019,1027,1138,1143,1192$, $1209,1210,1319,1320,1347$.

Thermal Properties 822, 1166.

Specific Heats 153, 226, 237, 246, 263, 285, 335, 362, 374, 440, 445, 447, 1003, 1131, 1175, 1212, $1223,1353$.

Thermal Conductivity 559, 852, 919.

Boiling Points 31, 43, 56, 116, 151, 154, 193, 237, 301, 308, 445, 447, 703, 844, 897, 899, 948, $1027,1269,1320,1348,1358$.

Melting Points 24, 110, 242, 294, 355, 686, 707, 708, 743, 920, 1071.

Ignition Temperatures 360, 977, 1051.

Points of Calefaction 990.

Heats of Vaporisation 450, 647.

Heats of Fusion.

Heat of Mixing 89, 125, 156, 196, 197, 218, 237, 249, 250, 285, 425, 445, 647, 951, 1064, 1131 , 1152, 1236.

Electrical Properties 914, 1339.

Electrical Conductivities 304, 369, 387, 394, 454, 611, 632, 663, 710, 715, 815, 946, 959, 979. $985,1042,1043,1054,1176,1233$.

Ionic dissociation $632,683,740,773$.

Ionic velocities 683, 700, 946, 1042.

Dissociative Power 683.

Dielectric Constants 719, 813, 916, 1260.

Electrical Absorption 1260.

Electrical Dispersion 1172.

Electrical Reflection 760 .

Electrical Refraction 760, 1172.

Magnetic Properties.

Magnetic Behavior.

Magnetic Susceptibility.

Electro-magnetic Rotation of the Plane of Polarized Light 475, 1304.

Optical Properties.

Refractive Indices $69,144,170,245,432,569,583,681,692,832,972,1103,1167,1174,1188$, $1221,1278,1302,1305,1307$.

Reflecting Power.

Absorption.

Absorption Spectra 1172. 
Physical Properties-Continued

of Ethyl Alcohol-Water Mixtures-Continued Miscellaneous.

Velocity of Sound in Mixed Vapors.

Velocity of Sound in the Mixed Liquids.

Velocity of Reactions $612,683,853,878,1046,1062,1076,1090,1100,1140,1184,1228,1235$, $1264,1283,1288,1325,1329,1341$.

of Higher Saturated Monohydric Aliphatic Alcohol-Water Mistures 279, 362, 600, 642, 697, 987, $1210,1220,1225,1269,1270$.

of Saturated Polyhydric Aliphatic Alcohol-Water Mixtures.

of the Unsaturated Alcohol-Water Mixtures 1203.

Equilibrium Relations in systems of two or more components 1146.

for Methyl Alcohol and Methyl Alcohol-Water Mistures 385, 648, 693, 784, 791, 887, 944, 1057, 1233, 1313.

for Ethyl Alcohol and Ethyl Alcohol-Water Mixtures 317, 540, 558, 594, 618, 671, 699, 754, 822, 823, $893,899,948,1021$.

with Gases $135,139,211,310,391,469,486,495,553,564,599,616,748,795,885,907,940,981$, $995,1159,1200,1345,1352,1373$.

with Liquids. Hygroscopicity $359,466,498,499,500,698,699,762,831,859,861,884,890,931$, $988,1009,1028,1058,1076,1095,1138,1230,1233,1252,1274,1278,1281,1282,1283,1308,1340$, $1362,1366,1368$.

with Solids $63,98,120,174,203,317,318,345,385,582,603,610,628,648,691,693,696,721,725$, $731,737,762,771,777,794,797,807,815,836,841,860,924,927,929,941,944,1044,1074,1089$, $1111,1123,1130,1134,1145,1160,1163,1206,1223,1243,1248,1256,1275,1300,1313,1330,1335$, 1357.

Vapor Composition and Distillation of Non-aqueous Mistures 733, 884, 897, 988, 1052.

Elevation of the Boiling Point 701, 725, 730, 887, 1122, 1128, 1254, 1272, 1342.

Depression of the Freezing Point 513, 698, 873, 968.

for the Higher Saturated Monohydric Aliphatic Alcohols and Their Mixtures with Water 693, $727,825,1155$.

for the Saturated Polyhydric Aliphatic Alcohols and Their Mistures with Water 1366. for the Unsaturated Alcohols and Their Mirtures with Water 693.

Chemical Behavior 829.

of Methyl Alcohol 288, 523, 821, 1184 .

of Ethyl Alcohol 808, 829, 1030.

Reactions with Other Substances 42, 74, 213, 219, 253, 256, 315, 434, 535, 762, 829, 945, 997, $999,1015,1032,1101,1124,1142,1226,1235,1297,1308,1375$.

Ozidation of Alcohol 55, 71, 166, 185, 635, 834, 974, 982, 1034, 1078, 1135, 1139, 1171, 1201, $1208,1238,1250$.

\section{Reduction of Alcohol.}

Action of Dehydrating Agents 28, 60,107, 141, 166, 181, 219, 244, 270, 303, 344, 368, 381, $877,900,935,943,944,954,973,994,995,1118,1119,1156,1158,1285,1336$.

Double Decompositions 831, 1101, 1281, 1282, 1283.

Action of Catalyzers 76, 938, 955, 997, 998, 1004, 1015, 1016, 1020, 1059, 1153, 1190, 1204, 1238 , $1250,1297,1360$.

Action of Heat 221, 270, 344, 381, 953.

Action of Light 1261, 1327.

Electrochemical Behavior 53, 78, 316, 699, 835, 846, 912, 969, 980, 1083, 1360.

Stability. Spontaneous Decomposition $55,76,1078$.

of Higher Saturáted Monohydric Aliphatic Alcohols 277.

of Saturated Polyhydric Aliphatic Alcohols $25 \%$.

of Unsaturated Alcohols. 
Purification 184, 301, 370, 428, 441, 459, 467, 521, 530, 542, 544, 545, 576, 627, 656, 674, 682, 713, 744, 786, $1031,1086,1102,1125,1150,1168,1170,1182,1207,1254,1310,1315,1328,1359$.

61

611

6111

61111

611111

611112

611113

611114

61112

611121

611122

611123

611124

611125

61113

611131

611132

611133

611134

61114

611141

611142

611143

611144

611145

611146

61115

6112

61121

61122

61123

61124

61125

612

6121

61211

61212

61213

61214

61215

6122

613

614

Detection of Impurities $90,183,321,365,542,552,554,587,634,641,653,667,957,1039,1265$. of Water.

Chemical Methods 207, 337.

Alkali and Alkaline Earth Metals.

Sodium.

Potassium.

Calcium 1243.

Magnesium.

Metallic Amalgams.

Sodium.

Potassium.

Calcium.

Magnesium 1243.

Aluminium 1243.

Metallic Oxides.

Sodium oxide.

Calcium oxide 1243.

Barium oxide 1243.

Aluminium oxide.

Metallic Salts.

Sodium sulphate.

Potassium carbonate.

Calcium chloride.

Calcium carbide $838,866,1214,1376$.

Potassium-lead iodide 1129, 1376.

Copper sulphate 88, 1214.

Miscellaneous 311, 351, 1 15, 1214.

Physical Methods 796.

Density Determinations 1371.

Refractive Index.

Critical Solution Temperature $117,422,464,735,838,859,960,1033,1058,1066,1094$, 1116, 1117, 1120, 1167, 1173, 1252, 1334, 1376.

Velocity of Reaction $853,1062,1090,1100,1107,1140,1185,1235,1257,1288,1329,1341$.

Miscellaneous 443, 508, 743, 744.

of Aldehydes 522, 847, 1243.

Chemical Methods 554, 557, 586, 752, 778, 847, 950.

Oxidation $397,398,556,1218$.

Reduction.

Double Compound 483.

Sulphite-fuchsine 209, 356, 377, 493, 590, 604, 778, 789, 1083, 1376.

Miscellaneous 410, 1045.

Physical Methods.

of Methyl Alcohol 306, 366, 379, 415, 494, 525, 655, 811, 863, 864, 886, 895, 901, 902, 905, 922, 1031, $1077,1081,1082,1126,1189,1243,1253,1267,1280,1326,1372$.

of Ethyl Alcohol 239, 252, 293, 297, 329, 330, 358, 402, 423, 655, 775, 1031, 1077, 1268, 1280, 1326, 1372 .

of the Higher Alcohols. Fusel Oil 127, 264, 349, 383, 428, 522, 554, 575, 633, 655, 785, 814, 1006 , $1031,1243,1372$.

of Esters 753, 1243.

of Ethers.

of Ketones 626.

of Fatty Acids 1067, 1243. 
6211

6212

62121

62122

62123

62124

62125

622

623

624

625

6311

63111

631111

631112

631113

631114

63112

631121

631122

631123

631124

631125

63113

631131

631132

631133

631134

63114

631141

631142

631143

631144

631145

631146

631147

63115

6312

63121

63122

63123

63124

Purification-Continued.

Quantitative Determination of Impurities 615, 634, 653, 1265, 1323.

of Water.

Chemical Methods.

Physical Methods 195, 510, 675, 1114.

Density 205, 1276, 1371.

Refractive Index 205, 783, 1024, 1047, 1164, 1181, 1196, 1276.

Critical Solution Temperature 735, 838, 960, 1033, 1066, 1094, 1095, 1116, 1120, 1167. $1177,1252,1334,1357,1376$.

Velocity of Reaction 1288, 1329, 1341.

Miscellaneous 606, 1051, 1071, 1186, 1245, 1371.

of Aldehydes 493, 763, 778, 793, 1045, 1093, 1296, 1317.

of Methyl Alcohol 282, 288, 306, 379, 494, 623, 811, 851, 863, 864, 1058, 1077, 1267, 1326.

of Ethyl Alcohol 281, 290, 315, 330, 432, 520, 555, 613, 776, 800, 801, 806, 834, 838, 923, 926, 934 , $1077,1239,1245,1258,1268,1306,1326$.

of Higher Alcohols. Fusel Oil 349, 389, 428, 481, 510, 550, 574, 598, 738, 785, 814, 870, 874, $1061,1178$.

of Esters 288, 753, 806 .

of Ethers 1323.

of Ketones 288.

of Fatty Acids 1067.

Removal of Impurities 283, 542, 682, 908, 1109, 1265.

of Water $117,140,149,160,399,1142,1175,1224,1251,1370$.

Chemical Methods 22, 57.

Alkali and Alkaline Earth Metals.

Sodium 199, 413, 433, 477, 679, 710, 741, 828, 832, 838, 970, 1046, 1054, 1094, 1273, $1275,1313$.

Potassium.

Calcium 1069, 1087, 1109, 1164, 1167, 1185, 1230, 1231, 1243, 1257, 1285, 1288, 1309, $1329,1341,1376$.

Magnesium

Metallic Amalgams.

Sodium.

Potassium.

Calcium.

Magnesium 973, 1037, 1110, 1167, 1243.

Aluminium 750, 768, 838, 1214, 1243, 1244, 1376.

Metallic Oxides.

Sodium Oxide.

Calcium Oxide $25,53,60,84,90,97,102,132,155,183,199,207,213,254,283,285$, $291,371,413,433,455,526,623,651,679,710,717,722,741,810,837,838,861,884$, $941,967,970,1023,1033,1052,1065,1094,1105,1148,1167,1174,1175,1176,1214$, $1230,1234,1257,1322,1341,1360,1376$.

Barium Oxide 183, 207, 741, 1094, 1174, 1234, 1299, 1376.

Aluminium Oxide.

Metallic Salts 471.

Sodium Sulphate 60

Potassium Carbonate 1, 10, 90, 102, 155, 283, 771.

Calcium Chloride 7, 9, 11, 17, 27, 41, 60.

Calcium Carbide 830, 857, 858, 890, 933, 943, 1257.

Copper Sulphate 102, 431, 832, 838, $861,884,890,970,1105,1231,1275,1300,1313$, 1360.

Potassium Tartrate 10

Potassium Acetate 60.

Miscellaneous 1338.

Physical Methods.

Distillation of Binary Mixtures 186, 189, 336, 353, 375, 1029.

Distillation of Ternary Mixtures 986, 1029.

Crystallisation or Freezing 24, 660, 707, 754, 932, 1013.

Miscellaneous 29. 
Purification-Continued.

Removal of Impurities-Continued.

632

6321

63211

632111

632112

632113

632114

63212

632121

632122

63213

63214

6322

633

634

635

636

64

641

of Aldehydes 177, 181, 1170, 1243.

Chemical Methods 778, 1083.

Oxidation Methods.

Silver Nitrate 722, 1097.

Silver Oxide 974, 1097, 1218, 1376.

Potassium Permanganate 576, 1045.

Potassium Bichromate.

Reduction Methods 1016.

Sodium.

Metalic Amalgams 1376.

Double Compound Methods 483, 1112.

Polymerisation Methods with Alkali 1045.

Physical Methods 722, 778, 1150, 1376.

of Methyl Alcohol 233, 1243.

of Ethyl Alcohol.

of the Higher Alcohols. Fusel Oil 140, 428, 1243.

of Esters, Ethers, Ketones, Fatty Acids 177, 262, 434, 1102, 1243.

Separation of Alcohols from Each Other 733, 1280.

Qualitative Detection 864.

Quantitative Separation 851, 864.

Purification of Compounds other than Alcohols 1254, 1275.

Alcoholometry 15, 95, 131, 195, 200, 205, 281, 307, 370, 501, 592, 613, 615, 675, 808, 812, 869, 903, 923, 926 , $990,1120,1177,1213,1239,1245,1258,1298,1306,1311,1334,1371,1377,1378$.

General Treatises $27,30,70,171,178,204,255,271,273,275,287,290,292,298,386,396,439,444,485$, $497,543,546,547,669,688,765,845,855,862,1056,1077,1181,1374$.

Alcoholometers 20, 35, 39, 68, 121, 124, 136, 167, 200, 232, 474, 565, 640, 765, 1071.

Hydrometers $12,13,16,18,21,23,50,70,73,105,113,115,126,148,152,161,162,163,164,175,180$, $194,198,210,261,267,272,274,519,536,560,577,589,591,617,631,745,747,770,913,942,1169$, $1193,1276$.

Dilatometers 106, 111, 266, 1371 .

Ebulliscopes. Vaporimeters $31,43,87,96,100,101,111,116,118,129,132,187,189,201,214,289$, $295,299,307,308,341,720,764,790,1001,1186$.

Capillarimeters 146, 208, 229, 236, 339, 460, 510, 518, 541, 574.

Alcoholometric Tables 2, 8, 20, 35, 45, 90, 102, 105, 119, 142, 163, 164, 168, 173, 182, 207, 215, 238, 259, $272,284,348,367,380,433,434,465,487,489,497,524,537,538,546,595,645,684,685,729,782,869$, $926,964,975,1040,1050,1096,1151,1169,1194,1213,1215,1216,1240,1242,1265,1311,1364,1376$.

Taxing of Liquors $4,5,105,215,516$.

Miscellaneous 6, 14, 360, 745 .

Miscellaneous 434, 464, 925.

Density of Water 59, 122, 123, 143, 363, 421, 623, 630, 799, 824, 1217.

Thermal Expansion of Water 122, 123, 143, 484, 614, 638, 799, 817, 824, 1132.

Density Determination Methods 433, 770, 913, 925, 1376.

Picnometers 820, 913, 952, 1114, 1376.

Drying of Moist Air and other Gases 202, 300, 325, 452, 502, 534, 1049.

Preparation and Treatment of Dehydrating Agents $319,320,551,570,625,750,756,768,1244,1376$. Distillation Methods 200, 258, 279, 301, 307, 309, 375, 441, 467, 526, 544, 627, 674, 678, 713, 714, 812, $1029,1143,1198,1246,1322,1328,1359,1370$.

Bibliographies 326, 444, 445, 515, 883, 961, 1116, 1168, 1184, 1363, 1376. 


\section{CORRECTIONS.}

PAGE. LINE. Should read- instead of-

3299 "milliliter" "millimeter"

344 last "Curve II" "Curve III"

$372 \quad$ Invert fig. 6.

$3798 \quad$ " $\frac{25^{\circ}}{4^{\circ}} \quad$ " 40 "

3807 "higher" "lower"

387 last " $(\mathrm{t}-25)^{3}$ " “ $(\mathrm{t}-25)^{5}$ "

4065 "fig. 10" “fig. 11"

4223 from last "with" "within"

42910 from last "from" "for"

4376 from last " 13 th" " "18th"

4534 " 4883 " “ 882 "

468 bet. 3 and 4 insert "Sendersen's, see 1204" 